\title{
STATEMENT OF QuALIFICATIONS
}

\section{for \\ RURAL REHABILITATION PROJECT AFGHANISTAN}




\section{STATEMENT OF QUALIFICATIONS}

\section{for \\ RURAL REHABILITATION PROJECT AFGHANISTAN}

$\triangle A R Z \triangle A$ Engineering Company

July 1990 
July 27,1990

\section{VITA}

Suite 200

1815 N. Lynn Street

Arlington, VA 20209

Attention: Mr. M. Sediq Ashan

\section{Dear Mr. Sediq:}

It was a pleasure to meet you in Chicago on July 18. Both Mr. Perret and I enjoyed an interesting and fruitful conversation which provided us the opportunity to learn about the rural rehabilitation project that VITA is currently performing in Afghanistan. We are keenly interested in assisting you on this undertaking.

The attached qualification document is structured into three main sections to address the items in your questionnaire. The section on corporate information includes a description of Harza along with information on our organizational structure, branch and project offices, professional resources and computer facilities. The section on relevant experience describes our project assignments in Afghanistan, Pakistan, Asia and the Middle East, and include a list of Harza projects performed for the USAID. Descriptions of our training and dam rehabilitation experience along with fact sheets on current IQC contracts are also provided in that section. The third section includes several relevant brochures. (As you requested, I have enclosed copies of all Harza current brochures in a separate folder).

As mentioned during our conversation, Harza is a multidisciplinary consulting firm serving private and governmental clients throughout the world in the planning and development of land, water and energy resources. The firm which was established in 1920 is owned entirely by its employees. In 1989 , Harza companies had revenues of $\$ 75.6$ million.

Harza worked continuously in Afghanistan for 20 years until 1980, when the war forced our resident engineer on the Kajakai Dam Gates Project to leave the country. During the same period, we were very active in Pakistan and in the last ten years have further increased our volume of work in that country. Currently, we have seven projects on-going in Pakistan including four irrigation/drainage assignments, a flood control project, a water resources planning project, and a hydroelectric project. Harza has maintained an office in Peshawar since 1980. 
VITA

July 27,1990

Page Two

Harza has extensive experience in working with USAID. Over the years, we completed 54 assignments sponsored by that agency and currently, we are working on 15 different assignments in 9 countries. The volume of work remaining on these USAID projects is in excess of U.S. $\$ 20$ million.

We trust that this document meets your requirements. Should you need clarification or require additional information, please let us know. Thank you again for the opportunity to submit our qualifications.

$$
\text { for } \begin{aligned}
& \text { Richard C. Rudberg } \\
& \text { Vice President and } \\
& \text { Area Manager Asia, } \\
& \text { Middle East, Africa }
\end{aligned}
$$

$\mathrm{RCR} / \mathrm{lar}$

Enclosure: As noted 


\section{RURAL REHABILITATION PROJECT, AFGANISTAN}

\section{Table of Contents}

Transmittal Letter

Table of Contents

Corporate Information

Description of Harza

Harza Engineering Company Organization Chart

Engineering Operations Organization Chart

The Harza Companies

Harza Personnel

Computer Equipment Facilities

Relevant Experience

Experience in Afghanistan

Kajakai Dam Gates Project

Electric Power Improvement

Kabul Gas Turbines

Helmand Valley Power Market Survey

Experience in Pakistan

Irrigation System Management II

Warsak Dam Stilling Basin

Chashma Barrage

Mardan Salinity Control and Reclamation Project

Command Area Development Project

Swabi Salinity Control Reclamation

Flood Protection Sector

Chashma Right Bank Canal Irrigation: System Performance Monitoring

Baluchistan Groundwater Development Project

Kalabagh Dam Project

Fordwah Eastern Sadiqia 


\section{Table of Contents (cont'd)}

Representative Experience in Asia

Small Scale Irrigation Management

Irrigation Systems Rehabilitation

Small Scale Irrigation Project

Irrigation System Rehabilitation

Nam Mun and Nam Chi Irrigation Projects

Harza Representative Projects in the Middle East

Gotvand Irrigation Project

Jordan Valley Irrigation Project - Stage II

Qatif - Area Project

Ghuwayba Agricultural Drainage Project

Current Indefinite Quantity Contracts

ISPAN-IQC Contract

Evaluation of the Regional Center for Remote Sensing

Current Assignments Under TECAID

List of USAID and USAID - Supported Assignments

Experience in Training and Technology Transfer

Harza Engineering Company Overview of Training Experience

Qualifications for Dam Rehabilitation Assignments

Brochures

Annual Review

Hydroelectric Power Plants

Agricultural and Irrigation Services 


\title{
DESCRIPTION OF HARZA
}

Harza Engineering Company is a consulting firm established in 1920. Its principal office is in Chicago, Illinois. Address and communication numbers for Harza are as follows:

\author{
Harza Engineering Company \\ 150 South Wacker Drive \\ Chicago, Illinois 60606-4288 \\ U.S.A.
}

Telephone: (312) 855-7000

Cable Address: HARZENG CHICAGO

Telex: $25-3540$

$25-4444$

Fax: (312) 236-8010

Consulting services are also provided through the affiliated firm of Harza Engineering Company International L.P., and through its principal subsidiaries Harza Environmental Services, Inc., and Stetson-Harza, Inc.

\section{Complete Independence and Ownership}

Harza is an independent consulting organization directed chiefly by engineers who are complemented by professionals in related fields. The company has no affiliation, direct or indirect, with construction companies, equipment manufacturers, government agencies or financial institutions. It is Harza's conviction that complete independence is requisite for service devoted to the client's maximum benefit.

Harza is entirely owned by its officers, associates, and professional employees; the Board of Directors is elected from the officer group. Thus, all actions taken by the firm are directed by officers who have a professional responsibility to our clients. All of Harza's owners are full-time employees of the firm.

\section{Credit Rating and Assets}

Harza has a rating of $3 \mathrm{~A} 1$ with Dun \& Bradstreet; this is the highest credit rating on the rating scale established by that firm for companies of Harza's size. In our latest financial statements, the assets of the parent company was $\$ 22,591,000$. The total assets of the consolidated group was $\$ 37,527,000$. 


\section{Personnel}

Harza and its affiliates currently employ 774 full-time personnel. Sixty-three percent of our personnel are professional engineers or specialists in the sciences. Among the 472 Chicago-based personnel, 181 have advanced degrees, including 33 with Doctorates.

Harza is fully staffed and has in-house capability in the disciplines required for each phase of engineering development. These disciplines include the traditional fields of civil, structural, geotechnical, sanitary, electrical, and mechanical engineering, agricultural, hydrology, geology, and environmental sciences, and also resource economy, financial and permitting assistance, ecology, forestry, fish and wildlife, and soil conservation.

\section{Services}

Harza's available services include every phase of the development of a project: from reconnaissance, through feasibility investigations, design, contract documents, engineering services during construction, and on to start-up and operation.

Harza is diversified, with its primary activity being the development and control of water resources for electrical power, irrigation, flood control, land reclamation, water supply, and pollution abatement. In addition, Harza is actively engaged in: agriculture, transportation, power generation, electric power transmission and distribution, telecommunications, underground excavation, highways, roadways, and bridges, industrial and municipal solid disposal, services to the mining industries, and a variety of specialized fields.

\section{In-House Computer Facilities}

Harza makes extensive use of computers in all its operations including engineering, management, and accounting. The in-house facilities include large computers, Intergraph CADD equipment, high speed printers, plotters, PC stations, and direct connection to time-shared computer systems. 


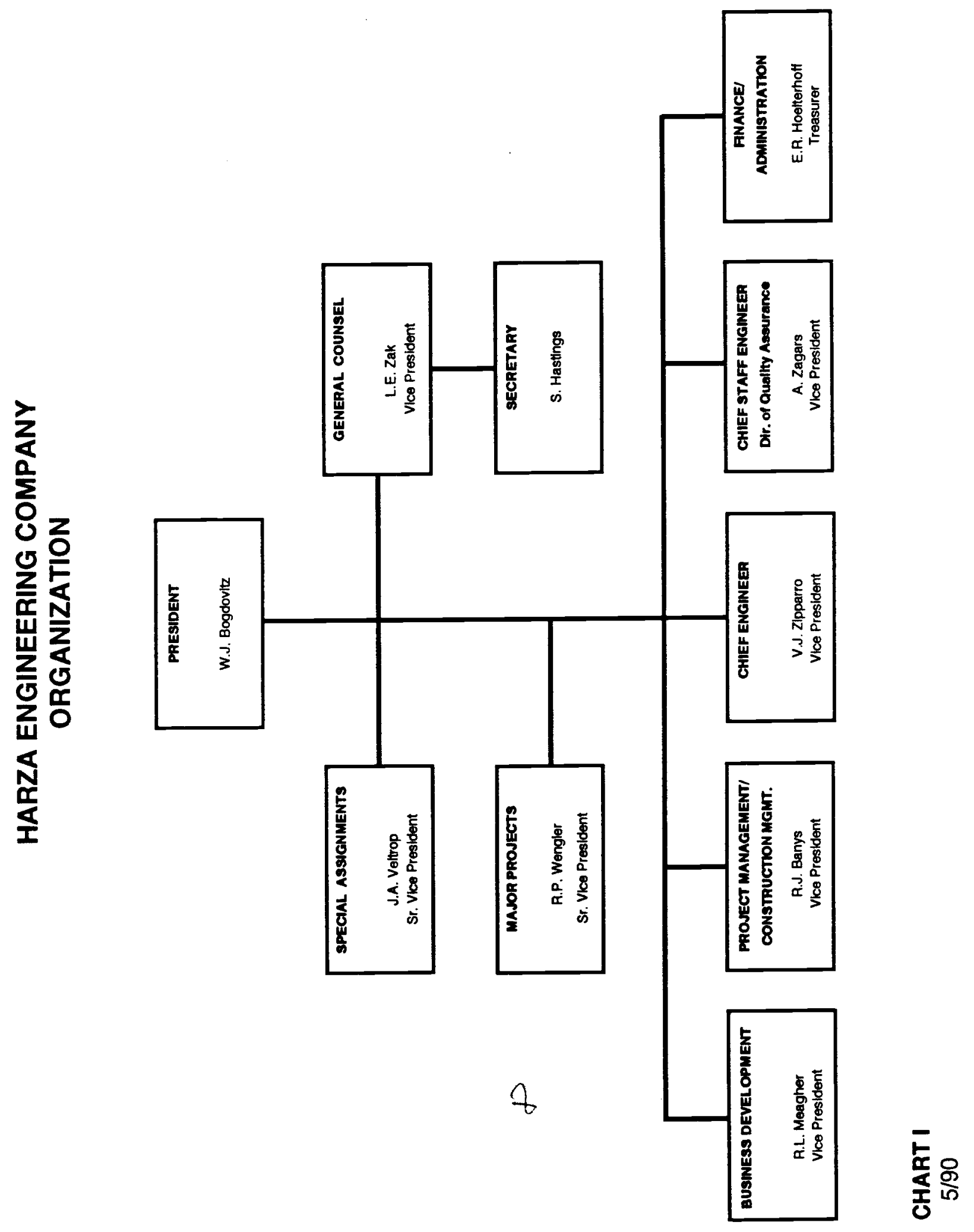




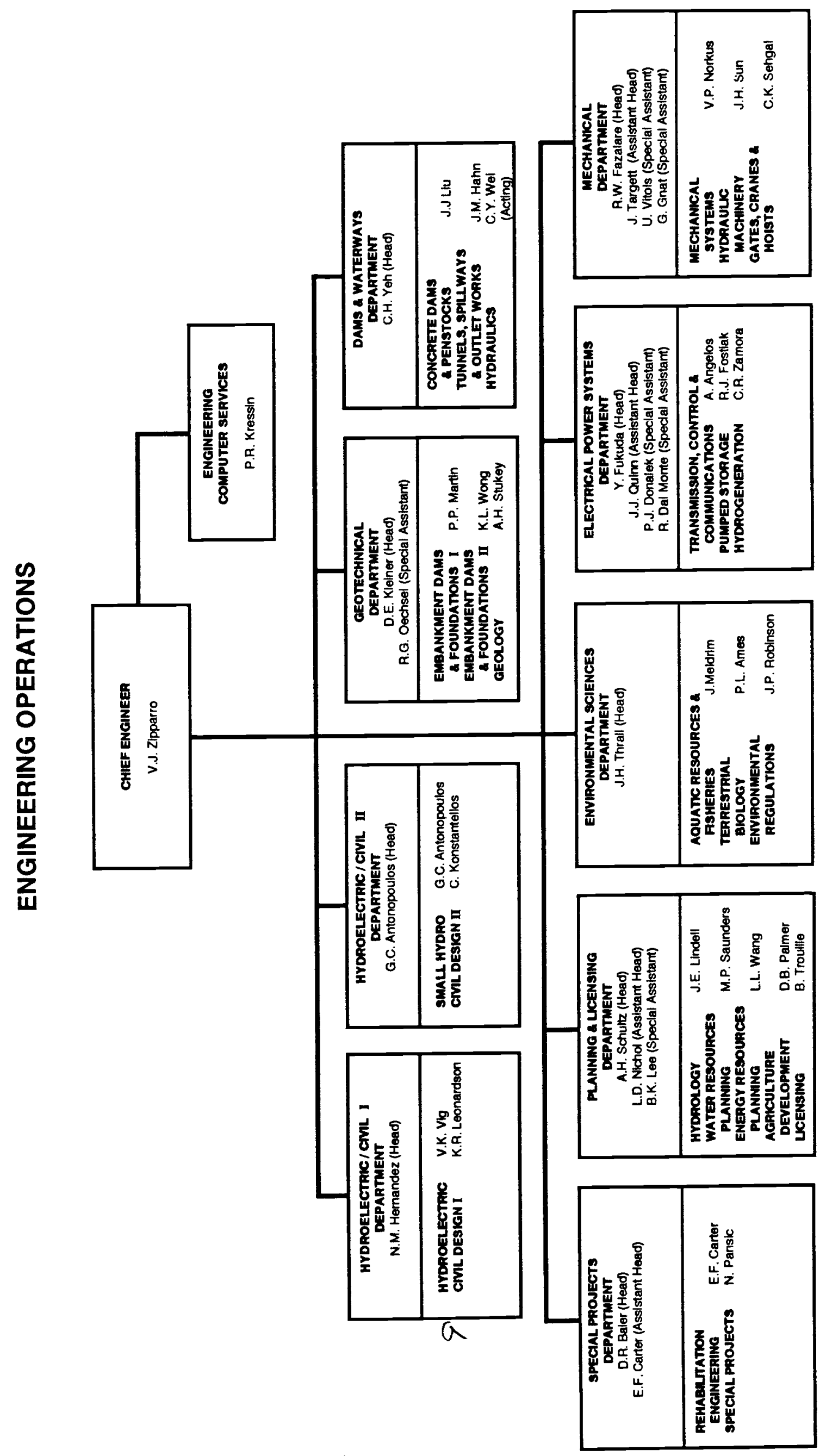

$\geq$
采。
孚 


\title{
THE HARZA COMPANIES
}

\author{
Harza Engineering Company \\ Consulting Engineers \\ 150 South Wacker Drive \\ Chicago, Illinois 60606-4288 \\ (312) 855-7000 \\ Fax (312) 236-8010 \\ Telex 25-3540
}

\section{United States}

\section{Regional Offices}

Colorado: 7979 East Tufts Avenue

Parkway, Suite 303

Denver, Colorado 80237

(303) $779-4830$

Oregon: 11675 SW 66th Avenue

Portland, Oregon 97223-8531

(503) 684-2701

\section{Subsidiaries}

Stetson-Harza, Inc.

185 Genesee Street

Utica, New York 13501

(315) 797-5800

Stetson-Harza, Inc.

250 Jordan Road

Troy, New York 12180

(518) 283-8080

Stetson-Harza, Inc.

Concord Center

10 Ferry Street

Suite 310

Concord, New Hampshire 03301

(603) 226-2888

Harza Environmental Services, Inc.

150 South Wacker Drive

Suite 1200

Chicago, Illinois 60606-4288

(312) $855-3300$

\section{Worldwide Offices}

Harza Engineering Company

Santo Domingo, Dominican Republic

Alexandria, Giza, Cairo, Egypt

New Delhi, Pune, India

Jakarta, Indonesia

Amman, Jordan

Islamabad, Pakistan

Bakel, Senegal

Harza Engineering Company International L.P.

Buenos Aires, Ituzaingo, Argentina

Dhaka, Bangladesh

Chengdu, China

Guatemala City, Guatemala

Kingston, Jamaica

Amman, Jordan

Lahore, Peshawar, Pakistan

Asuncion, Ayolas, Paraguay

Caracas, Venezuela

Harza Canada, Inc.

Toronto, Ontario, Canada 


\section{HARZA PERSONNEL}

Water, Land, and Energy Resources

Transportation and Municipal Engineering

Hazardous and Solid Waste Management

\section{PROFESSIONAL}

Agricultural Experts

Architects

CAD/CADD Experts

Chemical Engineers

Civil Engineers

Construction Experts

Construction Inspectors

Ecologists

Economists

Electrical Engineers

Estimators

Fish Experts

Geologists

Hazardous Waste Experts

Hydraulic Engineers

Hydrologists

Interior Designers

Landscape Architects

Mechanical Engineers

Mining Engineers

Planners: Urban/Regional

Sanitary Engineers

Specification Writers

Soils Engineers

Structural Engineers

Surveyors

Transportation Engineers

Water Resource Experts

TECHNICAL SUPPORT

Computer Specialists

Drafters

Engineering Technicians

\section{ADMINISTRATIVE}

Accountants

Administrators

Clerks

Financial Analysts

Secretaries and Word Processors

TOTAL

\section{Personnel}

17

29

18

6

81

17

25

12

4

40

5

16

23

5

13

16

4

3

43

2

4

20

4

22

39

9

21

Subtotal $\frac{20}{518}$

18

55
Subtotal $\quad$\begin{tabular}{r}
25 \\
\cline { 2 - 2 }
\end{tabular}

18

45

43

9

Subtotal $\frac{43}{158}$

774

Personnel listed above are full-time employees of the Harza Companies. In addition, Harza maintains an affiliated staff of professional and technical specialists, consultants, and subcontractors.

Nearly 26 percent of Harza's employees serve at project sites located in North America, Central America, South America, Asia, the Middle East, and Africa. 


\section{COMPUTER EQUIPMENT FACILITIES}

\section{Engineering Design}

Harza is presently integrating the computer systems it uses in all phases and aspects of technical services. Personal Computers, CADD workstations, computational servers, and database servers are linked by local area networks and software that integrates the various aspects and phases of analysis and design.

\section{Computational Server}

Harza's main computational server is a Stardent Titan Graphics Supercomputer. This machine, rated by the Argonne Labs standards Linpack 1000 x 1000 benchmark, is faster than a Cray(1) and is about 300 times faster than a 386/20 Mhz PC using the same benchmark. The Stardent utilizes the Unix operating system. Stardent Fortran is Fortran 77 compliant, with Vax and Cray extensions. The Stardent is being tuned to replace an 8-year-old Harris H-800 Mainframe. During the transition period, Harza is protecting its software investment by maintaining both systems.

\section{Personal Computers}

For PCs, Harza utilizes the IBM-PC standard. To obtain maximum efficiency and power, 80386 machines with math coprocessors, high resolution color screens, and large memory are the standard for new acquisitions. These machines are used to run a variety of software in support of technical efforts. Harza supports and maintains familiarity with a large variety of commercial software, thus helping to meet the needs of our clients. Harza also maintains a large library of in-house programs written by our technical staff and other specialists. These programs provide us with computational ability not found in commercial software.

\section{CADD}

Harza's CADD capabilities include twenty-five Intergraph workstations. These workstations, networked with Xerox's XNS network, use two Calcomp electrostatic plotters to provide Harza with the fastest of drawing production capabilities. One plotter is a black and white unit, while the second is a color unit capable of displaying 1,024 colors. Both units use roll fed velum or mylar and are 34 inches wide. The capacity of these two electrostatic plotters is over $400 \mathrm{E}$ sized drawings a day. Harza's CADD software is built around the Intergraph three dimensional drafting packages, and includes, in addition to the standard Civil, Hydrologic, Mechanical and Structural design and anal-

900724

O69\} \backslash \text { FS \CORPINFO CEF }
$-1-$

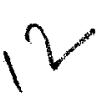


ysis software, the Intergraph Geographic Information System (GIS) software. Harza's staff is trained in both Intergraph and AutoCadd, and both software packages are maintained.

Harza uses Intergraph's dxf (drawing interchange format), IGES (Initial Graphic Exchange Specification), IGI (IGES in), and IGO (IGES out) translators to convert Intergraph IGDS digital files into dxf and IGES formatted files. Operational copies of Intergraph's Standard Interchange Format (SIF) processors are maintained for use with the IGES translators. These translators allow us to interchange files between several CADD packages including AutoCad, CADAM, and CALMA. Since 1985, Harza has been interchanging $\mathrm{dxf}$ and IGES formatted files with clients who use other CADD systems.

Harza's approach to the use of computer Aided Design, Drafting and analysis is to do our work in a three dimensional, networked environment. From the Planning and Licensing stages to the production of construction drawings, our environment not only gives us the ability to share data across disciplines, but also reduces the time required to produce the highest quality product.

\section{Network}

Harza is using its computational resources to improve communication between departments and disciplines. Harza's implementation of a local area networks links the technical staff with all three technical computer environments and with the word processing environment. The machines linked include PCs, Intergraph Unix workstations, VAXes, and the Stardent. The technical computer network uses both DECNet and XNS protocols over ethernet wiring, and provides a gateway to the Novell System Fault Tolerant (SFT) administrative services LAN.

\section{Word Processing System}

Word processing, secretarial, and administrative personnel use WordPerfect 5.0 running on a Novell SFT local area network. Secretarial workstations are located throughout the company. Each is equipped with an AT-class (80286) PC and a Hewlett-Packard LaserJet IID local printer. These workstations are connected through the network to two high-volume Hewlett-Packard LaserJet 2000 system printers.

For desktop publishing Harza uses 80386-based work stations running Xerox Ventura, Aldus PageMaker, and Lotus Freelance software for document creation. These stations are also on the local area network and have full access to the network facilities. The system includes high-resolution image scanning and manipulation, and optical character recognition capabilities using a Hewlett-Packard ScanJet Plus scanner and Calera Truescan hardware and software. Postscript printing capability is provided through Brightwork's PS-Publish. 


\section{EXPERIENCE IN AFGHANISTAN}

Project

Helmand-Arghandab

Valleys Power Market

Survey

Kajakai Dam Gates

Project

Kabul Gas Turbine Plant

Electric Power Improve-

ments Helmand Valley

Arghadab, Girishk Rehabilitation Project
Client

USAID

Ministry of Water and Power

World Bank

USAID

U.S. International Corporation
1976-77

1978-80

1974-77

1966-70

1960-1965

Years of Services

\author{
1976-77
}

Administration 


\section{CONSULTING ASSIGNMENTS WHICH BEST ILLUSTRATE QUALIFICATIONS}

The following information should be provided for each reference project in the format indicated below:

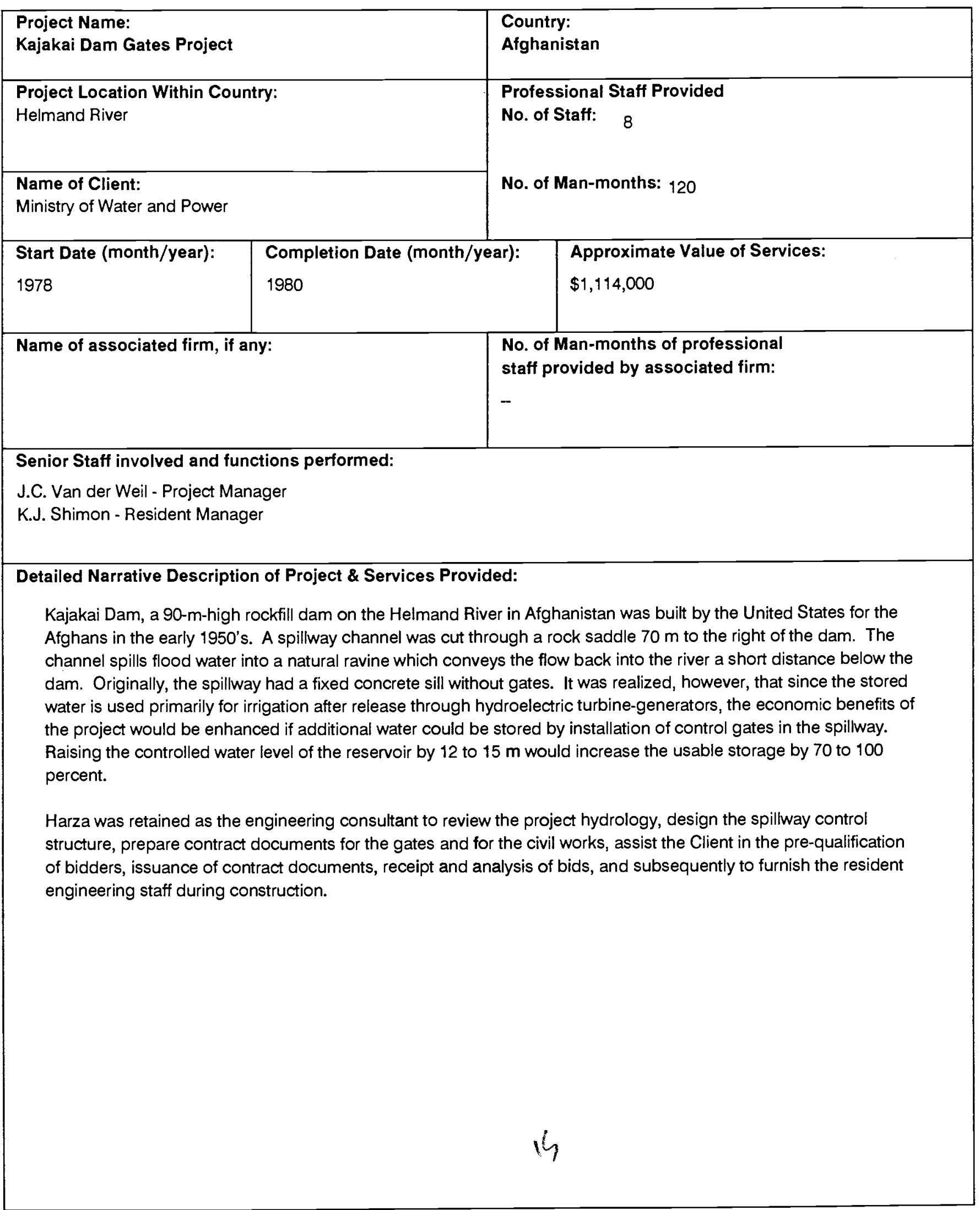




\section{CONSULTING ASSIGNMENTS WHICH BEST ILLUSTRATE QUALIFICATIONS}

The following information should be provided for each reference project in the format indicated below:

\begin{tabular}{|c|c|c|}
\hline \multicolumn{2}{|c|}{$\begin{array}{l}\text { Project Name: } \\
\text { Electric Power Improvement }\end{array}$} & $\begin{array}{l}\text { Country: } \\
\text { Afghanistan }\end{array}$ \\
\hline \multicolumn{2}{|c|}{$\begin{array}{l}\text { Project Location Within Country: } \\
\text { Helmand Valley }\end{array}$} & \multirow{2}{*}{$\begin{array}{l}\text { Professional Staff Provided } \\
\text { No. of Staff: Not Available } \\
\text { No. of Man-months: } 156\end{array}$} \\
\hline $\begin{array}{l}\text { Name of Client: } \\
\text { USAID }\end{array}$ & & \\
\hline $\begin{array}{l}\text { Start Date (month/year): } \\
1966\end{array}$ & $\begin{array}{l}\text { Completion Date (month/year): } \\
1970\end{array}$ & $\begin{array}{l}\text { Approximate Value of Services: } \\
\$ 464,000\end{array}$ \\
\hline \multicolumn{2}{|c|}{ Name of associated firm, if any: } & $\begin{array}{l}\text { No. of Man-months of professional } \\
\text { staft provided by associated firm: }\end{array}$ \\
\hline \multicolumn{3}{|c|}{$\begin{array}{l}\text { Senior Staff involved and functions performed: } \\
\text { D.T.S. Leong - Project Manager }\end{array}$} \\
\hline \multicolumn{3}{|c|}{$\begin{array}{l}\text { Harza provided engineering services for the modernization and expansion of the electric power systems of the cities } \\
\text { of Kandahar, Bost, Girishk, Chah-I-Anjir, Nad-I-Ali, and Marja in the Helmand Valley area of Afghanistan. The } \\
\text { assignment consisted of a detailed survey of the existing facilities and the planning and the design of the systems } \\
\text { including conversions of part of the system from } 3.3 \mathrm{kV} \text { to } 13.8 \mathrm{kV} \text {. }\end{array}$} \\
\hline \multicolumn{3}{|c|}{$\begin{array}{l}\text { Harza prepared a design report giving the recommended changes, additions, materials, and equipment required, } \\
\text { cost estimates and construction schedule. }\end{array}$} \\
\hline \multicolumn{3}{|c|}{$\begin{array}{l}\text { Services also included preparation of equipment specifications, issuing invitations for bids, bid evaluations, and } \\
\text { assistance with the purchasing and shipping of equipment. }\end{array}$} \\
\hline \multicolumn{3}{|c|}{$\begin{array}{l}\text { Resident engineers assigned to the project did the detailed line engineering, wrote work orders, and provided } \\
\text { engineering supervision of the construction. }\end{array}$} \\
\hline
\end{tabular}




\section{CONSULTING ASSIGNMENTS WHICH BEST ILLUSTRATE QUALIFICATIONS}

The following information should be provided for each reference project in the format indicated below:

\begin{tabular}{|c|c|c|}
\hline \multicolumn{2}{|l|}{$\begin{array}{l}\text { Project Name: } \\
\text { Kabul Gas Turbines }\end{array}$} & $\begin{array}{l}\text { Country: } \\
\text { Afghanistan }\end{array}$ \\
\hline \multicolumn{2}{|c|}{$\begin{array}{l}\text { Project Location Within Country: } \\
\text { Kabul }\end{array}$} & \multirow{2}{*}{$\begin{array}{l}\text { Professional Staff Provided } \\
\text { No. of Staff: N/A } \\
\text { No. of Man-months: } 21\end{array}$} \\
\hline $\begin{array}{l}\text { Name of Client: } \\
\text { World Bank }\end{array}$ & & \\
\hline $\begin{array}{l}\text { Start Date (month/year): } \\
1974\end{array}$ & $\begin{array}{l}\text { Completion Date (month/year): } \\
1977\end{array}$ & $\begin{array}{l}\text { Approximate Value of Services: } \\
\$ 258,000\end{array}$ \\
\hline \multicolumn{2}{|c|}{ Name of associated firm, if any: } & $\begin{array}{l}\text { No. of Man-months of professional } \\
\text { staff provided by associated firm: } \\
\text { - }\end{array}$ \\
\hline \multicolumn{3}{|c|}{$\begin{array}{l}\text { Senior Staff involved and functions performed: } \\
\text { F.C. Fischer - Project Manager } \\
\text { D.H. Sandell - Project Director }\end{array}$} \\
\hline \multicolumn{3}{|c|}{$\begin{array}{l}\text { Detailed Narrative Description of Project \& Services Provided: } \\
\text { Harza provided engineering services for a feasibility study for a power development program in Kabul. } \\
\text { Subsequently Harza assisted in the preparation of contract documents, issuance and evaluation of bids, and } \\
\text { provided recommendations for purchase of two } 16-20 \mathrm{MW} \text { gas turbine generators with and without combined cycle } \\
\text { operations. }\end{array}$} \\
\hline
\end{tabular}




\section{CONSULTING ASSIGNMENTS WHICH BEST ILLUSTRATE QUALIFICATIONS}

The following information should be provided for each reference project in the format indicated below:

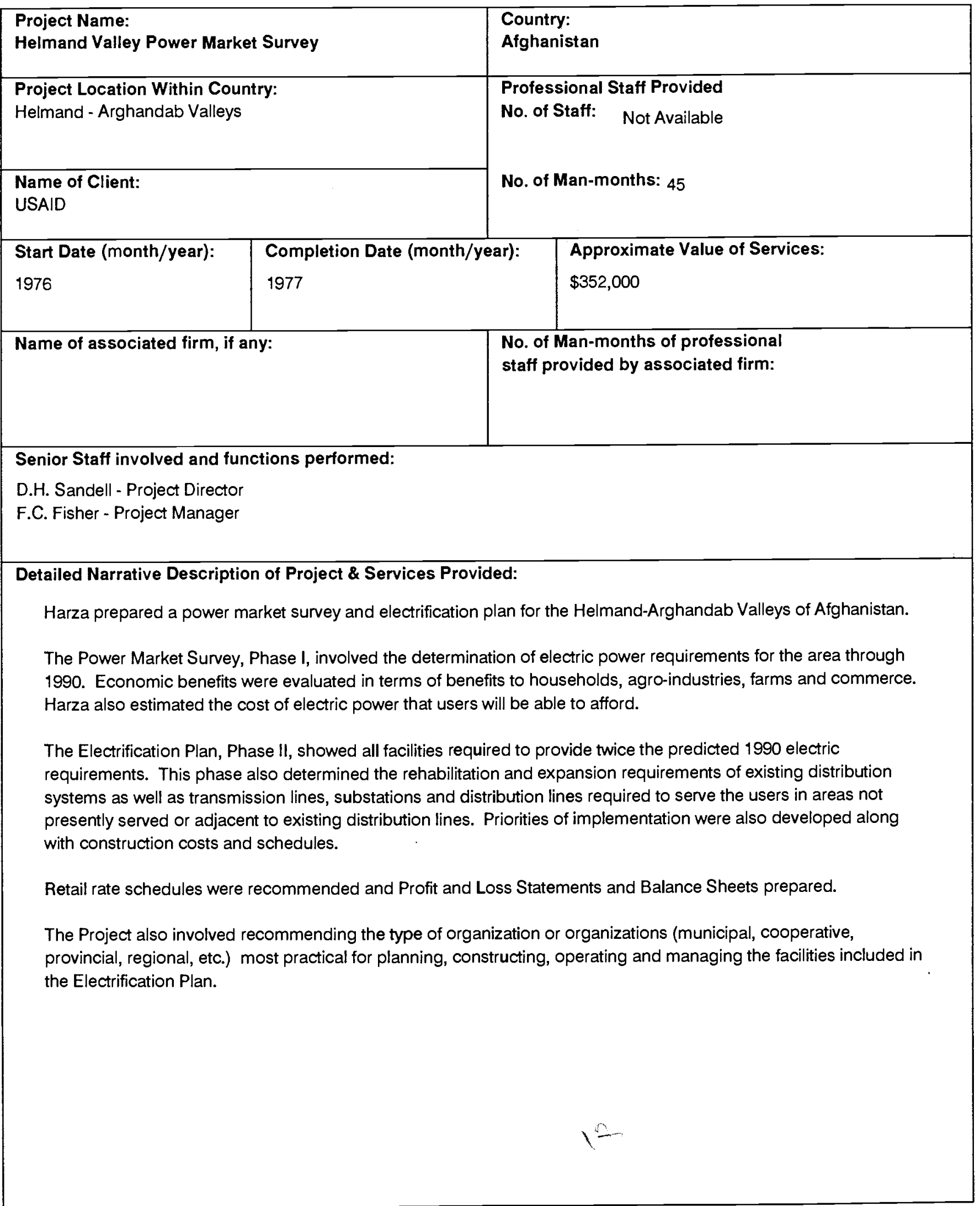




\section{EXPERIENCE IN PAKISTAN}

\section{Project and Location}

Fordwah Eastern Sadigia (South)

Irrigation System

Management II

Ghazi-Gariela Hydro

Project - Phase I

Flood Protection Sector

Water Sector Investment

Planning Study

O\&M Foreign Training for WAPDA Engineers

B-S Link Hydroelectric

Project

Chashma Right Bank

Canal Irrigation -

System Performance

Monitoring

Swabi Salinity Control

and Reclamation

Master Plan for Barani

Area Development

Chashma Command

Area Development,

Drainage
Client

Years of

Services

WAPDA

$1989-90$

USAID

1989-Date

WAPDA

World Bank

Federal Flood Commission

1989-Date

World Bank

1988-Date

World Bank

1987

ACE

1987

WAPDA

1986-87

Asian Development Bank

1988

Asian Development Bank

1986-88

WAPDA

1986-Date 


\section{EXPERIENCE IN PAKISTAN}

Project and Location

Baluchistan Groundwater

Development

KESC Distribution

Project

Kalabagh Dam Project

Engineering Study

$500 \mathrm{kV}$ Transmission

System Upgrading

Project

Hub Dam - Consulting

Dams Safety Training

Mardan-SCARP

Computation Procedure

for Canal Analyses

Comprehensive Flood

Management Plan -

Phase I

Indus Basin Planning

Project - Revised

Action Programme

Flood Damage Restora-

tion Project

Warsak Dam Stilling

Basin Repairs

\section{Client}

Asian Development Bank

1984-85

Karachi Electric Supply Corporation

1984

WAPDA

1982-88

World Bank

WAPDA

1981-83

World Bank

1980-84

WAPDA

1982

WAPDA

1979-Date

World Bank

1979-80

Federal Flood Commission

1977-78

WAPDA

1975-79

World Bank

NESPAK, IDA

1977-78

WAPDA

1977
900727

A900032P EIP

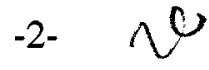




\section{EXPERIENCE IN PAKISTAN}

\section{Project and Location}

Extension of 500-kV

Transmission Line

Flood Management

System Appraisal

Accelerated SCARP's

Thatta - Sujajawal

Bridge

Tarbela Dam Project

Indus Basin Barrages

Indus Basin Link Canals

WAPDA General

Consulting

Mangla Spillway
Client

WAPDA

World Bank

Ministry of Fuel Power and Natural Resources

WAPDA

$1974-78$

Gammons, Ltd., Pakistan

1965-68

WAPDA

1964-73

World Bank

WAPDA

1960-72

WAPDA

1960-72

World Bank

WAPDA

1959-84

WAPDA

1958-68 


\section{CONSULTING ASSIGNMENTS WHICH BEST ILLUSTRATE QUALIFICATIONS}

The following information should be provided for each reference project in the format indicated below:

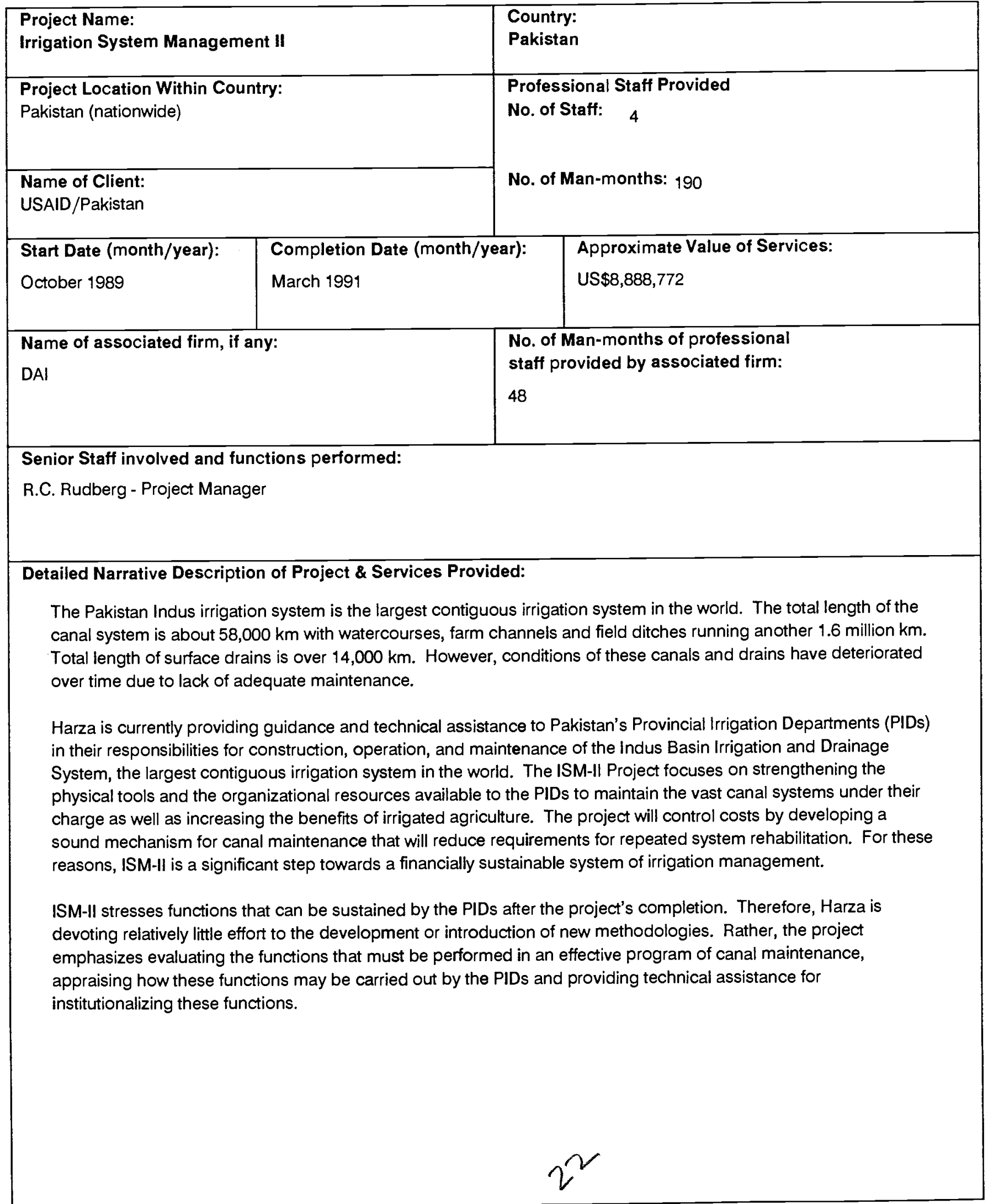




\section{CONSULTING ASSIGNMENTS WHICH BEST ILLUSTRATE QUALIFICATIONS}

The following information should be provided for each reference project in the format indicated below:

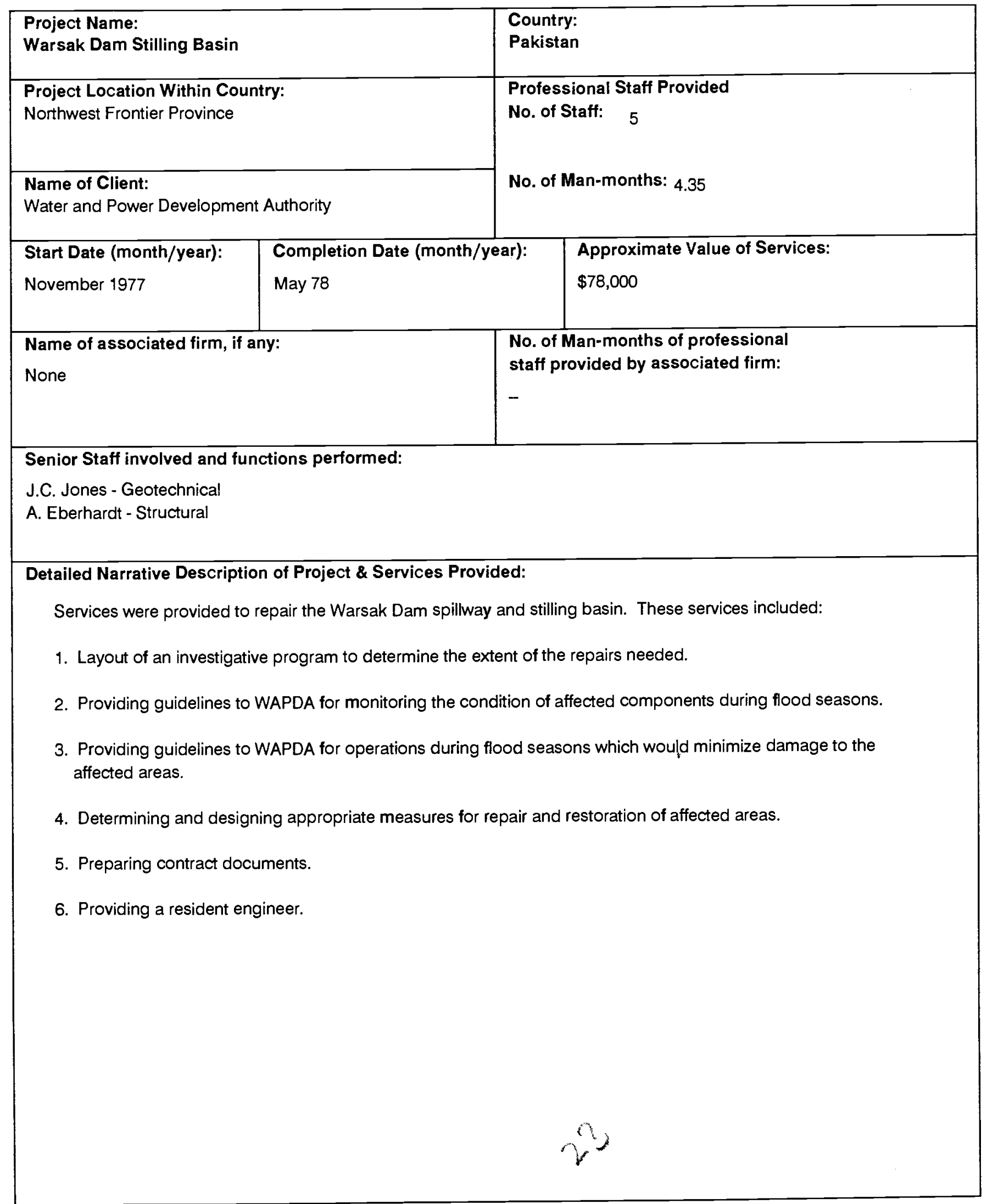




\section{CONSULTING ASSIGNMENTS WHICH BEST ILLUSTRATE QUALIFICATIONS}

The following information should be provided for each reference project in the format indicated below:

\begin{tabular}{|c|c|c|}
\hline \multicolumn{2}{|l|}{$\begin{array}{l}\text { Project Name: } \\
\text { Chashma Barrage }\end{array}$} & $\begin{array}{l}\text { Country: } \\
\text { Pakistan }\end{array}$ \\
\hline \multicolumn{2}{|c|}{$\begin{array}{l}\text { Project Location Within Country: } \\
\text { Indus Basin }\end{array}$} & \multirow{2}{*}{$\begin{array}{l}\text { Professional Staff Provided } \\
\text { No. of Staff: } 20 \\
\text { No. of Man-months: } 690\end{array}$} \\
\hline \multicolumn{2}{|c|}{$\begin{array}{l}\text { Name of Client: } \\
\text { Water and Power Development Authority }\end{array}$} & \\
\hline $\begin{array}{l}\text { Start Date (month/year): } \\
1960\end{array}$ & $\begin{array}{l}\text { Completion Date (month/year): } \\
1971\end{array}$ & $\begin{array}{l}\text { Approximate Value of Services: } \\
\$ 31,531,926\end{array}$ \\
\hline \multicolumn{2}{|c|}{ Name of associated firm, if any: } & $\begin{array}{l}\text { No. of Man-months of professional } \\
\text { staff provided by associated firm: }\end{array}$ \\
\hline \multicolumn{3}{|c|}{$\begin{array}{l}\text { Senior Staff involved and functions performed: } \\
\text { J.A. Scoville - Project Director }\end{array}$} \\
\hline \multicolumn{3}{|c|}{$\begin{array}{l}\text { As General Consultants to WAPDA, Harza had responsibility for the review of all design criteria and designs, } \\
\text { specifications and construction drawings prepared by Coode \& Partners for construction of the barrages; } \\
\text { coordination of the barrages with the link canals and other portions of the Indus Basin Project; and advice during } \\
\text { construction. }\end{array}$} \\
\hline \multicolumn{3}{|c|}{$\begin{array}{l}\text { For the Chashma Barrage Embankments, which extend approximately six miles across the Indus River Flood Plain, } \\
\text { Harza provided technical supervision for foundation explorations and designed the embankment sections. Harza } \\
\text { also furnished technical supervision of field investigations and design for the uplift-pressure relief wells at Chashma } \\
\text { and for the Rasul Barrage remedial works as well as the floor-uplift relief drains for the Marala Barrage remedial } \\
\text { works. }\end{array}$} \\
\hline \multicolumn{3}{|c|}{$\begin{array}{l}\text { In addition, Harza prepared designs for remodeling and raising the Marala Weir, advised the Client on remodeling } \\
\text { of Balloki Headworks, and the remodeling of Trimmu Barrage gates and headworks. }\end{array}$} \\
\hline
\end{tabular}




\section{CONSULTING ASSIGNMENTS WHICH BEST ILLUSTRATE QUALIFICATIONS}

The following information should be provided for each reference project in the format indicated below:

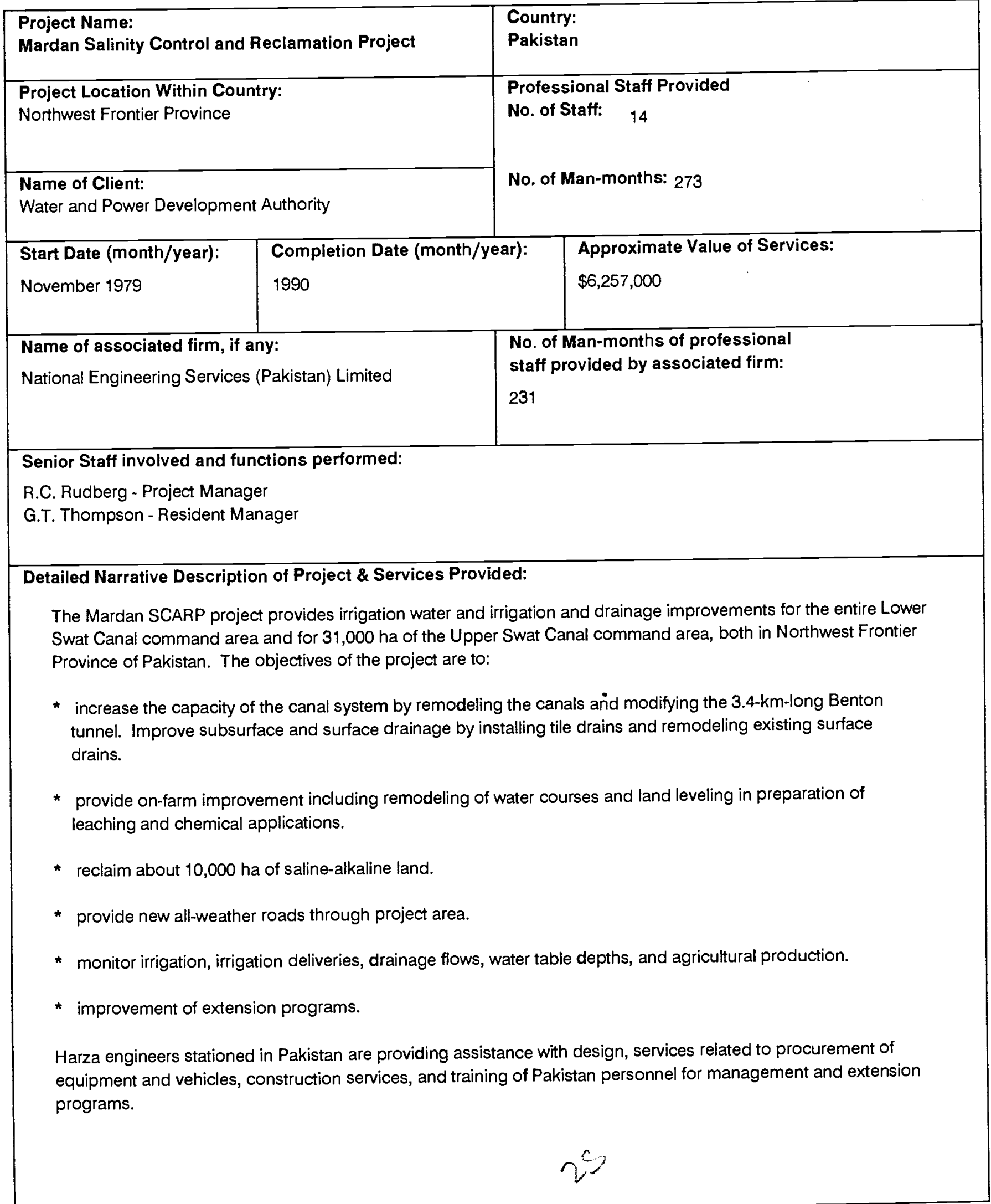




\section{CONSULTING ASSIGNMENTS WHICH BEST ILLUSTRATE QUALIFICATIONS}

The following information should be provided for each reference project in the format indicated below:

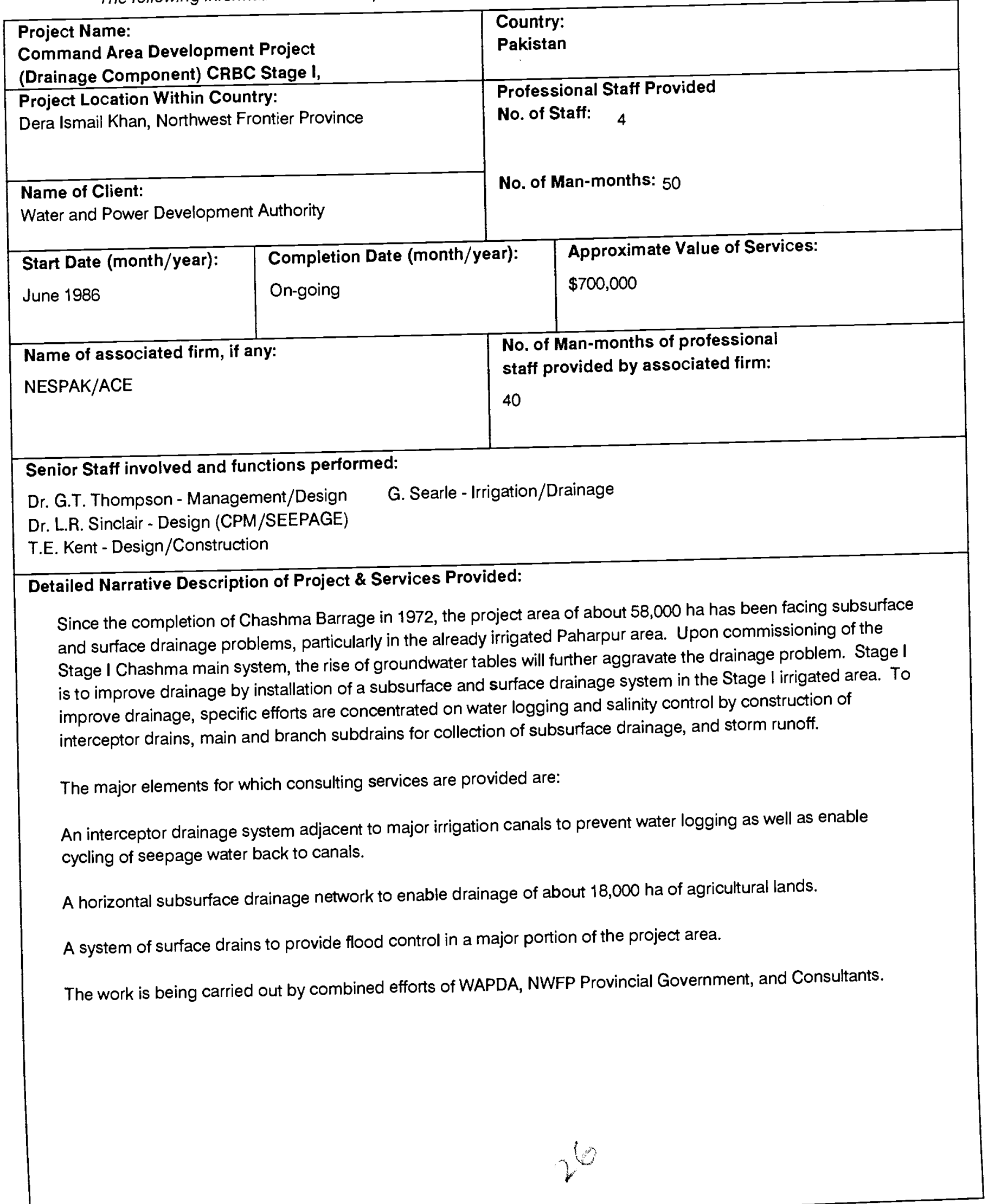




\section{CONSULTING ASSIGNMENTS WHICH BEST ILLUSTRATE QUALIFICATIONS}

The following information should be provided for each reference project in the format indicated below:

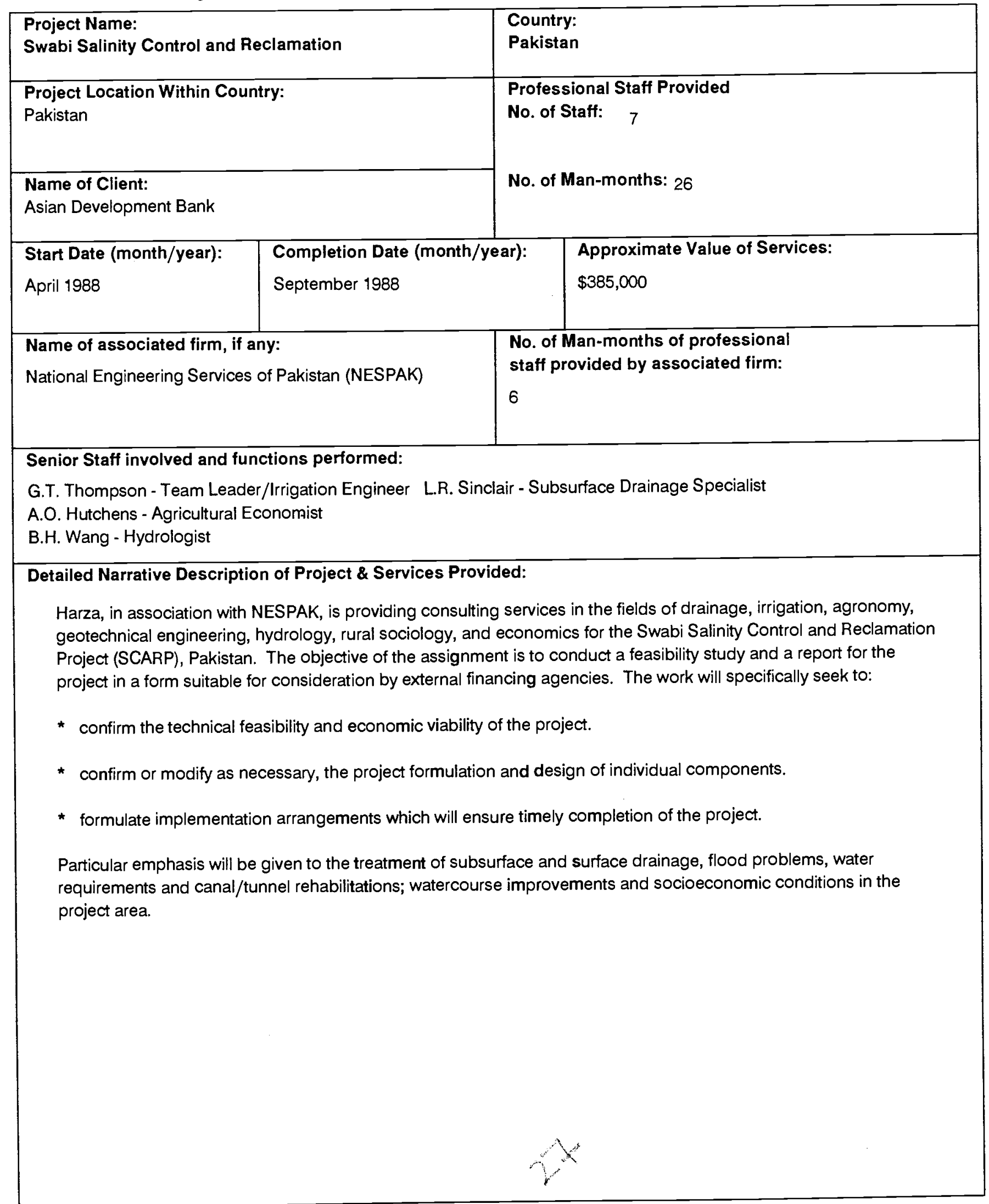




\section{CONSULTING ASSIGNMENTS WHICH BEST ILLUSTRATE QUALIFICATIONS}

The following information should be provided for each reference project in the format indicated below:

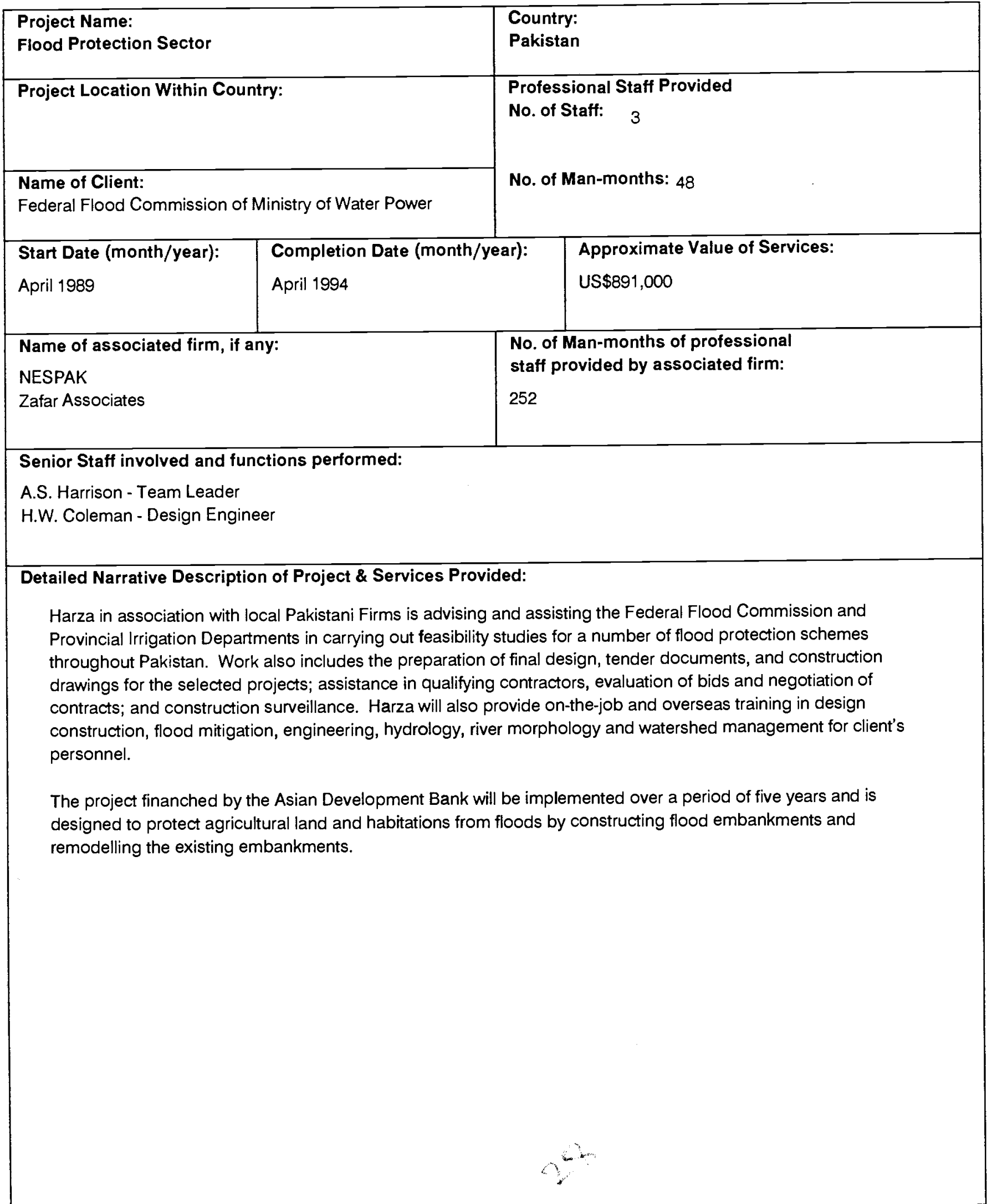




\section{CONSULTING ASSIGNMENTS WHICH BEST ILLUSTRATE QUALIFICATIONS}

The following information should be provided for each reference project in the format indicated below:

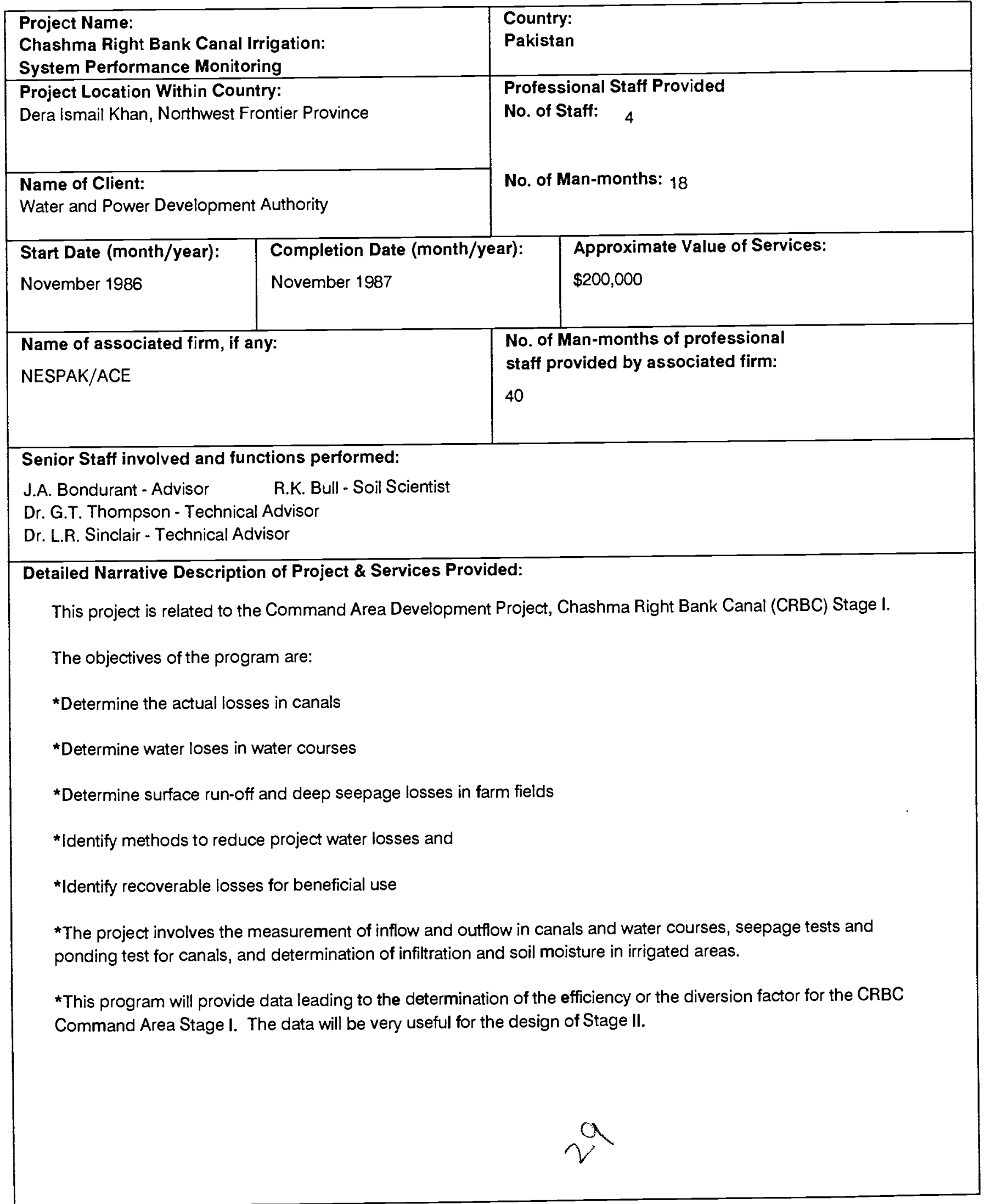




\section{CONSULTING ASSIGNMENTS WHICH BEST ILLUSTRATE QUALIFICATIONS}

The following information should be provided for each reference project in the format indicated below:

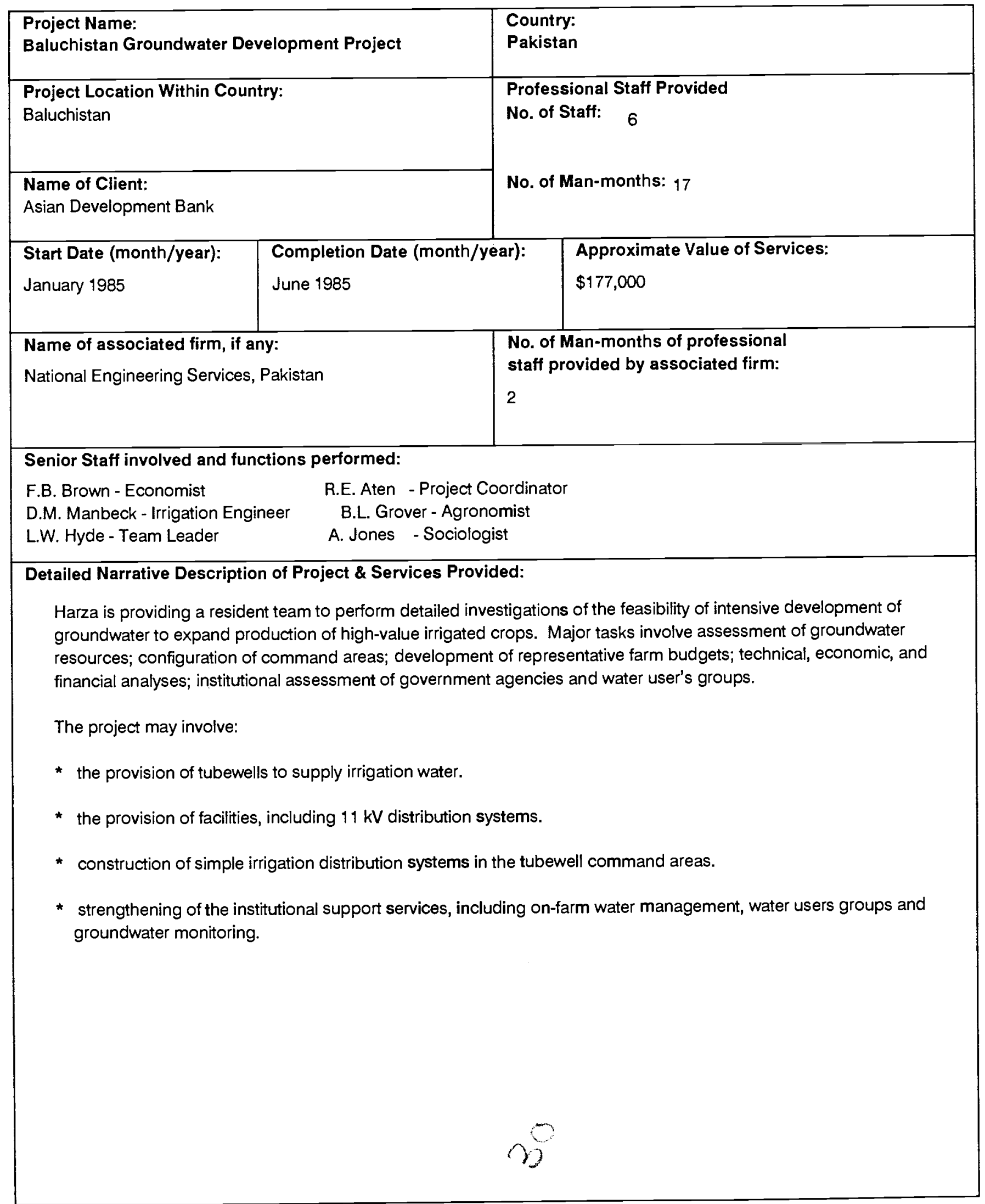




\section{CONSULTING ASSIGNMENTS WHICH BEST ILLUSTRATE QUALIFICATIONS}

The following information should be provided for each reference project in the format indicated below:

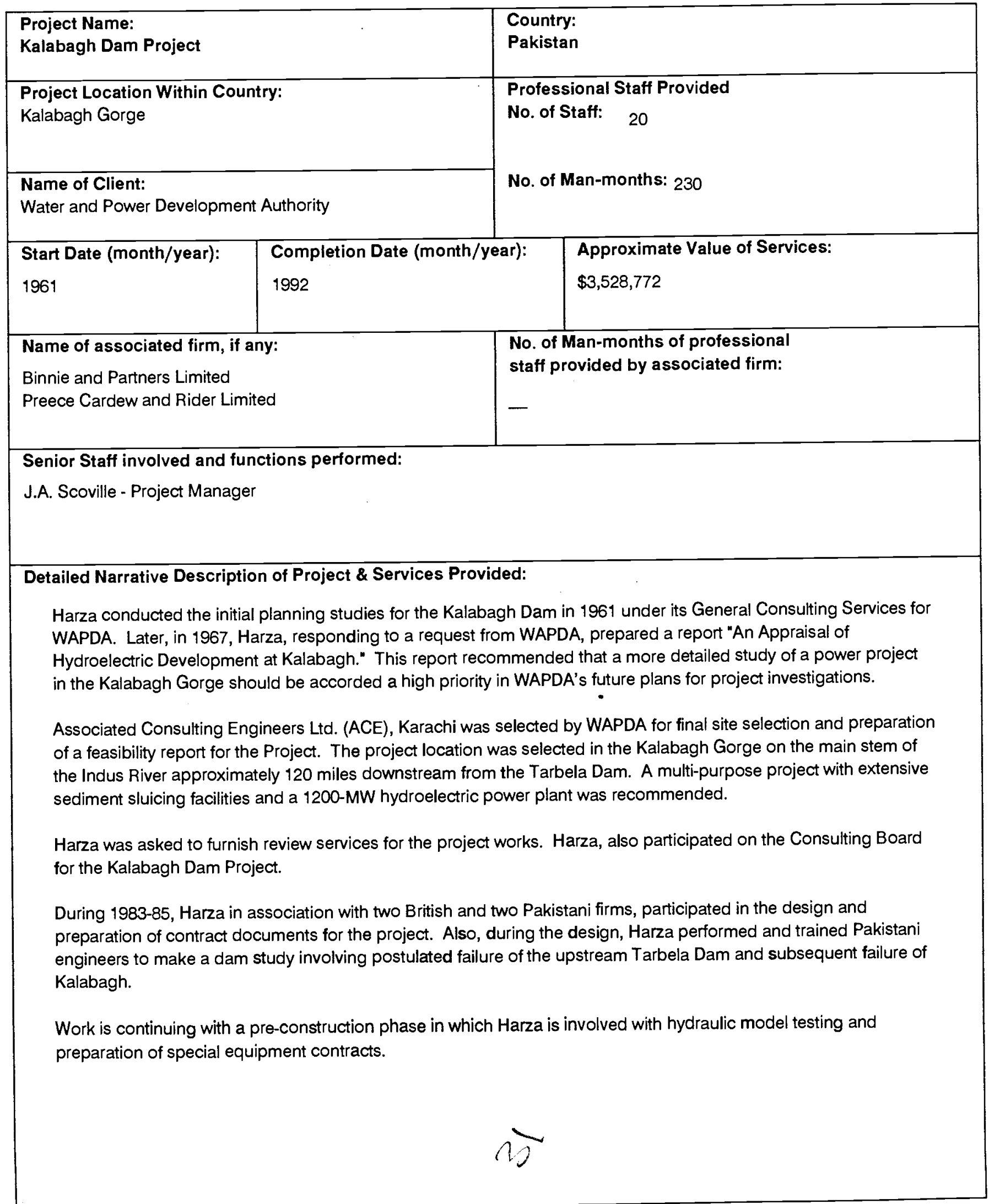




\section{CONSULTING ASSIGNMENTS WHICH BEST ILLUSTRATE QUALIFICATIONS}

The following information should be provided for each reference project in the format indicated below:

\begin{tabular}{|c|c|c|c|}
\hline \multicolumn{2}{|c|}{$\begin{array}{l}\text { Project Name: } \\
\text { Fordwah Eastern Sadiqia (South) }\end{array}$} & \multicolumn{2}{|c|}{$\begin{array}{l}\text { Country: } \\
\text { Pakistan }\end{array}$} \\
\hline \multicolumn{2}{|c|}{$\begin{array}{l}\text { Project Location Within Country: } \\
\text { Lahore }\end{array}$} & \multicolumn{2}{|c|}{$\begin{array}{l}\text { Professional Staff Provided } \\
\text { No. of Staff: } 2\end{array}$} \\
\hline $\begin{array}{l}\text { Name of Client: } \\
\text { Pakistan Water and Power }\end{array}$ & Iopment Authority (WAPDA) & \multicolumn{2}{|c|}{ No. of Man-months: 24} \\
\hline $\begin{array}{l}\text { Start Date (month/year): } \\
\text { January } 1989\end{array}$ & $\begin{array}{l}\text { Completion Date (month/y } \\
\text { January } 1990\end{array}$ & & $\begin{array}{l}\text { Approximate Value of Services: } \\
\$ 346,735\end{array}$ \\
\hline \multicolumn{2}{|c|}{$\begin{array}{l}\text { Name of associated firm, if any: } \\
\text { National Engineering Services Pakistan (PVT) Limited } \\
\text { (NESPAK) }\end{array}$} & \multicolumn{2}{|c|}{$\begin{array}{l}\text { No. of Man-months of professional } \\
\text { staff provided by associated firm: } \\
88\end{array}$} \\
\hline \multirow{2}{*}{\multicolumn{4}{|c|}{$\begin{array}{l}\text { Senior Staff involved and functions performed: } \\
\text { R.C. Rudberg - Project Manager E.F. Dudley - Environmental Expert } \\
\text { B.A. Anthony - Group Project Manager } \\
\text { W.P. Kohl - Team Leader }\end{array}$}} \\
\hline & & & \\
\hline \multicolumn{4}{|c|}{$\begin{array}{l}\text { Detailed Narrative Description of Project \& Services Provided: } \\
\text { Harza, in association with NESPAK, was chosen in } 1988 \text { to perform feasibility studies on a 330,000 (later expanded } \\
\text { to } 480,000 \text { ) acre area located } 200 \mathrm{~km} \text { south of Lahore. These engineering, economic, social, institutional and } \\
\text { environmental studies addressed the problem of water-logging and salinity. This occurs where the water table is } \\
\text { close to the land's surface. A large portion of the project area was turning barren (unsuitable for agriculture) at a } \\
\text { rapid rate and required sub-surface drainage. Harza implemented its recommendations by designing a sub-surface } \\
\text { drainage system for sample areas totalling at least } 20 \% \text { of the total area needing sub-surface drainage. Lowering } \\
\text { the water table by pumping, and allowance for future variation in cropping patterns were key design criteria. Harza } \\
\text { provided the project's team leader (a drainage expert) to lead the design effort and an environmental expert. The } \\
\text { assignment, which was initiated in } 1989 \text { and completed in 1990, was partially funded by the World Bank. }\end{array}$} \\
\hline
\end{tabular}



Harza is a multidisciplinary consulting engineering firm serving private and governmental clients throughout the world in the planning and development of land, water, and energy resources. The firm, which was es/ablished in 1920, is owned entirely by its employees and has a permanent staff of 790 .

Harza offers a full range of services from project concept to completion including: reconnaissance, pre-feasibility and feasibility studies; design engineering; contract documents; engineering services during construction; construction management; as well as assistance during financing, permitting, licensing, start-up, and operational phases.

Harza and its wholly owned subsidiary companies: Stetson-Harza an architectural engineering firm and HES, Inc., an engineering organization specializing in municipal, industrial, and hazardous waste management, maintain offices in five states in the United States and in 14 countries around the world.

Table of Contents

Letter from the President

Dams and Reservoirs

Generation and Power Systems

Public Works

Agriculture and River Basin Planning

Rehabilitation

Environmental Sciences

Harza Environmental Services

Stetson-Harza

Representative Clients

Directors/Officers 


\section{Letter from the President}

At the Harza Companies, the year 1989 can best be described in two words: achievement and promise-achievement for what was accomplished, promise for what lies ahead.

This annual review presents a document of the achievements: record revenues of $\$ 75.6$ million up $12 \%$ from last year and a $17.5 \%$ increase in the total value of acquisitions.

It reflects new assignments that range from dam rehabilitations in Utah and power substations in Naperville, Illinois, to water management in Egypt, flood protection in Pakistan, pumped storage in China, and water supply and sewerage systems in Venezuela. This review also documents Harza's progress on such long-term projects as the Rocky Mountain

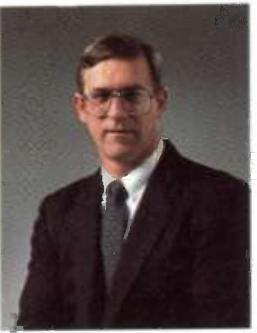

Walter J. Bogdovilz President Pumped Storage Project in Georgia, which is proceeding on schedule, and the Yacyreta Multipurpose Project in Argentina and Paraguay, which saw the closure of the main branch of the Parana River.

Nineteen-eighty-nine was a year Harza continued fulfilling the expectations of its clients for high quality professional consulting services. This commitment to quality translated into the same strong repeat business Harza has always enjoyed.

Certainly Harza is proud of past achievements. But the company knows that its ultimate success depends not on what was accomplished in the past, but on what it continues to accomplish now and in the future.

Harza's inspiration and dedication to quality comes from the promise the future holds.

With a new decade now beginning and a new century ahead, Harza has the momentum to make that promise come true. Because Harza believes that teamwork holds the key to success, it is building stronger, closer relationships with clients worldwide. The company is putting its energy into maintaining the tradition of innovation in design and problem solving by continuing to develop a professional staff of the highest quality and giving them the best tools available.

During the past year, Harza installed a super computer that runs technical programs with greater efficiency and provides state-of-the-art three dimensional modeling and large-scale finite element analysis. A newly installed local area network links the company's computer resources. And, as the company's technological sophistication has increased, Harza has strengthened its expertise in many professional areas, especially in the environmental sciences, a reflection of a commitment to meet growing concerns over the environmental impact of project development worldwide.

Simply stated, at the Harza Companies all that has gone before and all that lies ahead rests on the commitment to provide the highest level of professional consulting service possible. As the industry grows more competitive, this commitment to engineering excellence will continue to set Harza apart.

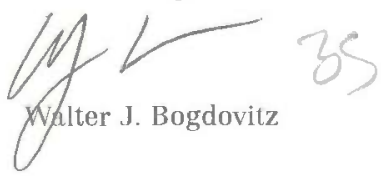




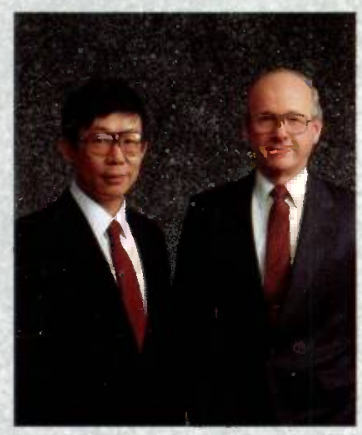

C. H. Yeh

Head, Dams and Waterways

David E. Kleiner Head, Geotechnical

Since the company's founding 70 years ago, Harza has been an industry leader in the design and construction of all types of dams and water resource projects. In the 1990s, with demands growing on natural resources from burgeoning populations and industrial development around the world, Harza, with all the in-house expertise necessary to handle all aspects of project development, is ready to meet the needs for expanded water supply both for population and industry.

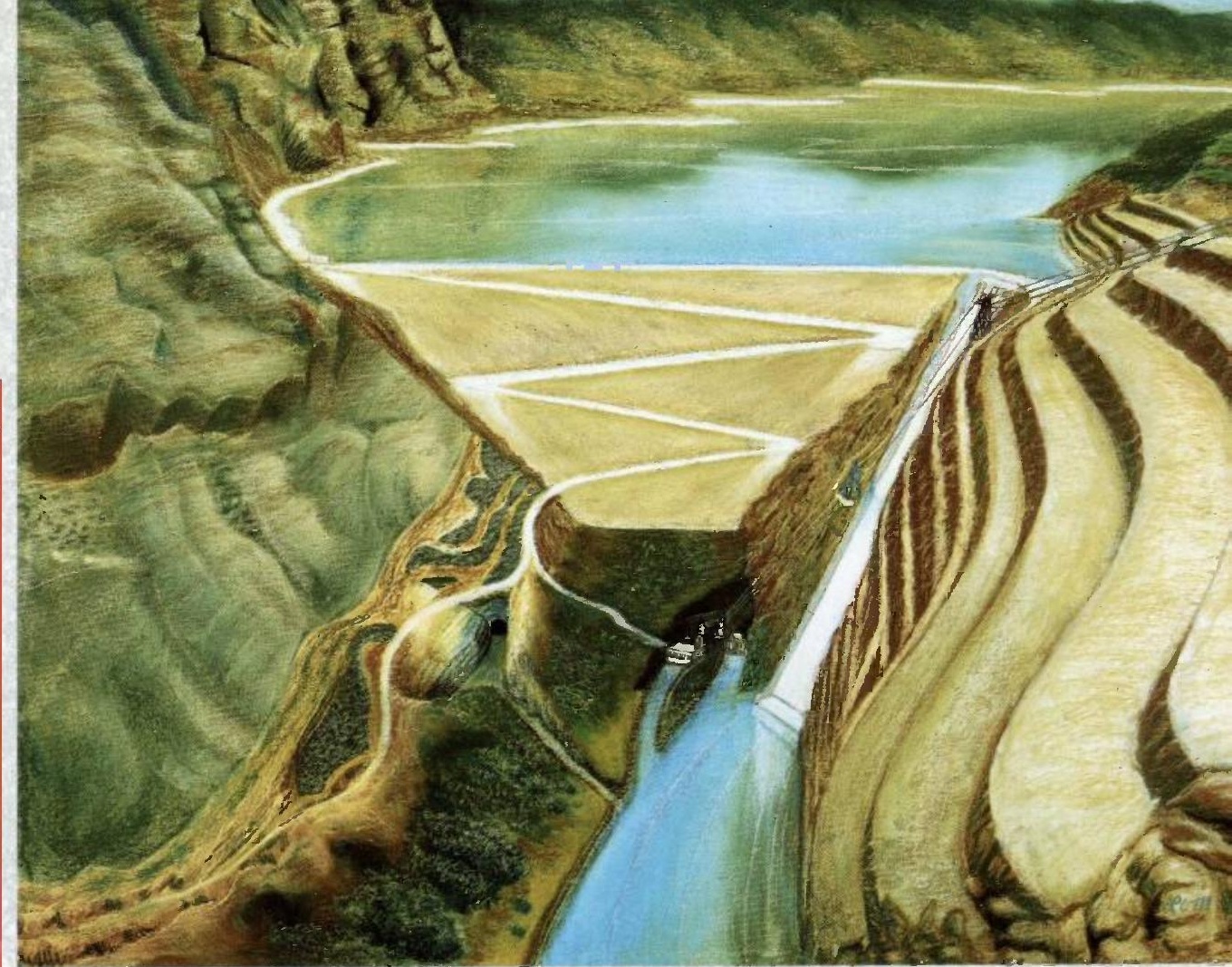

Artist's rendering of the Al Wehdah Dam on the Yarmouk

River, Jordan. The design for the 100-meter-high, concrete-

faced rockfill dam provides for future raising by an additional

40 meters. (Rendering by Lawrence C. McKienzie.)
Construction of the Caren Dam in Chile was completed in 1989. The 70-meter-high dam, which was built for the storage of copper tailings, is designed to be raised to a final height of $120 \mathrm{~m}$. Harza was responsible for the planning, design, preparation of contract documents, and geotechnical supervision during construction.

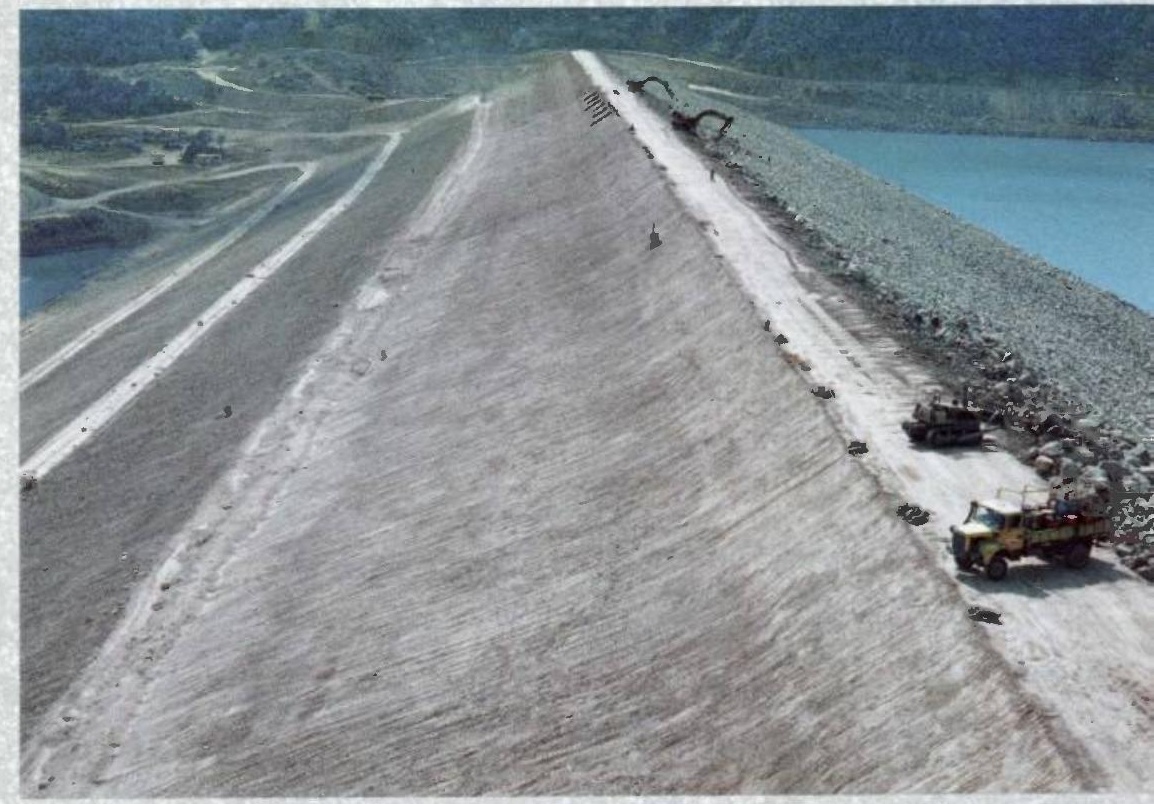




\section{Dams and Reservoirs}

In 1989, Harza completed contract documents for the $100 \mathrm{~m}$ high Al Wehdah Dam in Jordan. The $\$ 300$ million concrete-faced, rockfill storage facility will control and regulate the flows of the Yarmouk River for irrigation in the Jordan Valley. Al Wehdah has been designed for staged development to facilitate future raising by an additional 40 meters. The dam will impound a reservoir of 225 MCM and has the capacity of holding 50 years of sedimentation. Construction of the diversion tunnel and appurtenant works was completed in 1989. Harza assisted the government of China in the completion of design drawings for the civil works for the 245-meter-high Ertan Dam. The double-curvature arch dam design was chosen as the best option to take full advantage of topographic and geologic features of the chosen site. Because of the narrow, steepsided river valley and limited flood storage capacity, the design features three individual spillways to provide flood discharge capacities necessary to pass up to 24,000 cubic meters per second. Harza's involvement included in-service training and technology transfer. Harza also assisted in preparation of tender documents for civil works construction contracts.
The Colorado River Water Conservancy District has selected Harza and another firm to design the 120-foot-high Ritschard Dam and Reservoir. The development will create a 60,000-acre-foot reservoir on Muddy Creek, a tributary of the Colorado River, to enhance water supply to the city of Denver and western Colorado. In 1989, Harza completed phase one of the geotechnical investigations and testing. Harza will also perform comparison studies between earthfill and RCC dam types. Design activities will be completed by the end of 1990 . Construction is scheduled to begin in 1991.

Harza is also working in Colorado on the design of a new spillway for the lower reservoir dam at the Cabin Creek Pumped Storage Project. The design is interesting because it will place the new 145-foot-wide spillway through the crest of the existing rockfill dam. When operating in tandem with the existing drop inlet spillway and outlet works, the new spillway will enable the lower dam to pass the full Probable Maximum Flood (PMF) without being overtopped.

In recent years the body of knowledge concerning the performance of dams under various static and dynamic loads has vastly increased. As a result, design criteria have been revised and many older dams are being reassessed in regards to safety and stability.

For the city of Tacoma, Washington, Harza was retained to perform a number of tasks related to inspection and analysis of the safety and stability of Mayfield and Mossyrock Dams, which were designed by Harza over 25 years ago. Among other services, Harza conducted core drilling and testing, and finite element and maximum credible earthquake analyses on both dams.

Harza also conducted inspections and stability analyses of Peavey Falls Dam for Wisconsin Electric Power and Cabinet Gorge Dam for Washington Water Power. The work at Cabinet Gorge also included studies of PMF conditions at the 159-foot-high, 395-foot-long, double-curvature arch dam.

Harza continued serving the Tennessee Valley Authority in 1989 by conducting detailed seepage and earthquake stability studies on the 45-foot-high earthfill Beech Dam in Tennessee. The finite element seepage study has been completed and the final report will be submitted in 1990 containing Harza's recommended remedial measures.

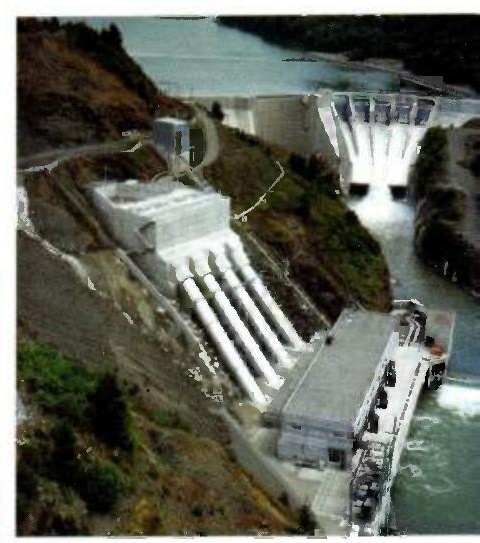

Harza returned to Mayfield Dam, Washington, 25 years after completing the project's design, to conduct safety and stability studies. 


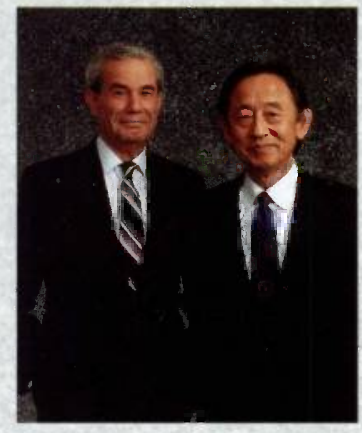

Richard W. Fazalare

Head, Mechanical

Yoneo Fukuda

Head, Electrical Power Systems

Hydroelectric generation has always been recognized as a leading source of clean, renewable energy, something which has gained significant importance today as worldwide concern has grown around environmental assessments and impacts. This same concern has also focused attention on pumpedstorage technology as an efficient means of generating peak-load power. Harza offers unsurpassed capabilities for the planning, design, and development of both conventional and pumpedstorage hydroelectric generation.

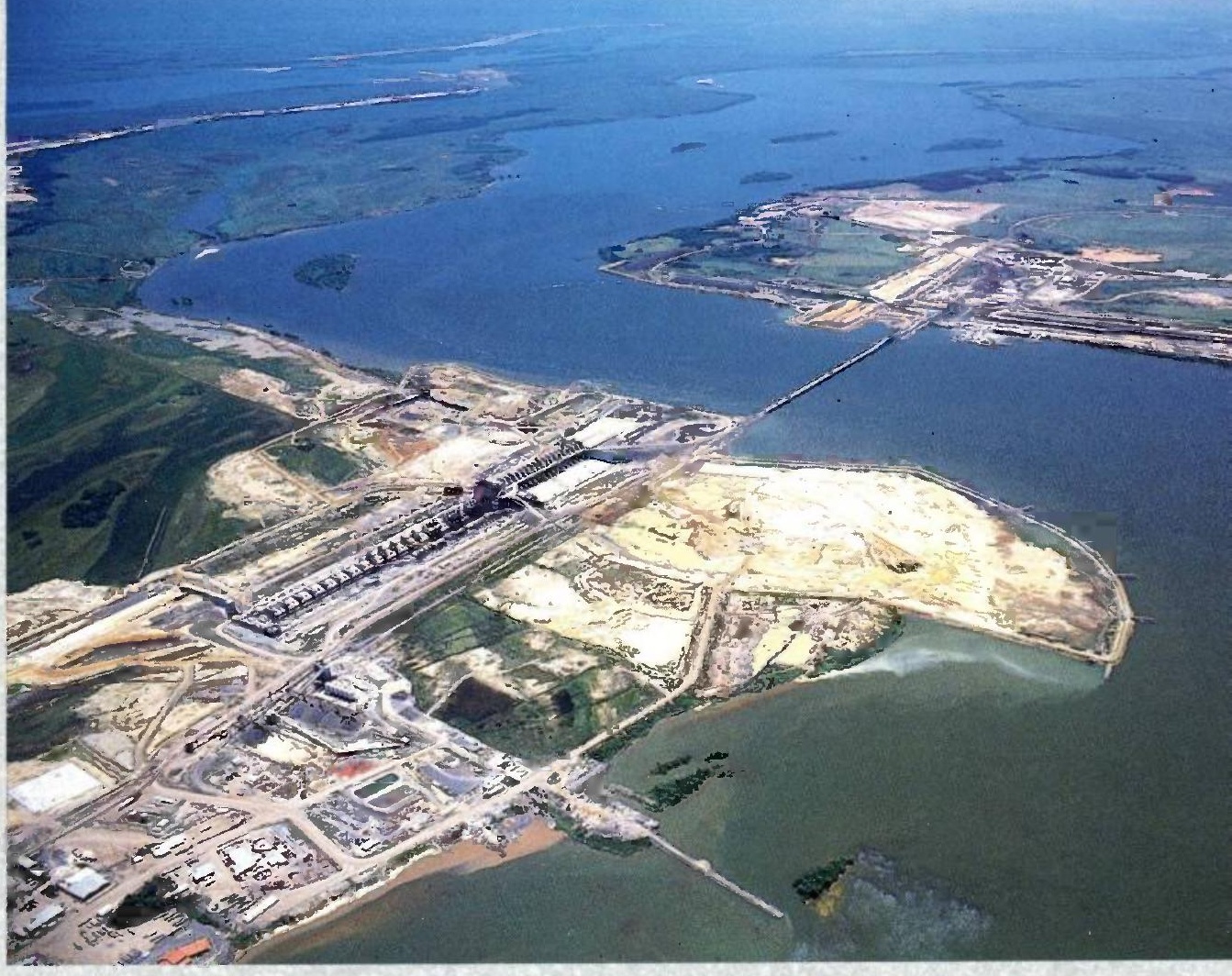

Looking upstream on the Parana River at the multipurpose Yacyreta Hydroelectric Project, this photograph dramatically shows the full extent of the multi-billion dollar project before the main river closure was completed. The main branch was closed in 1989 and work has commenced on construction of the main dam.

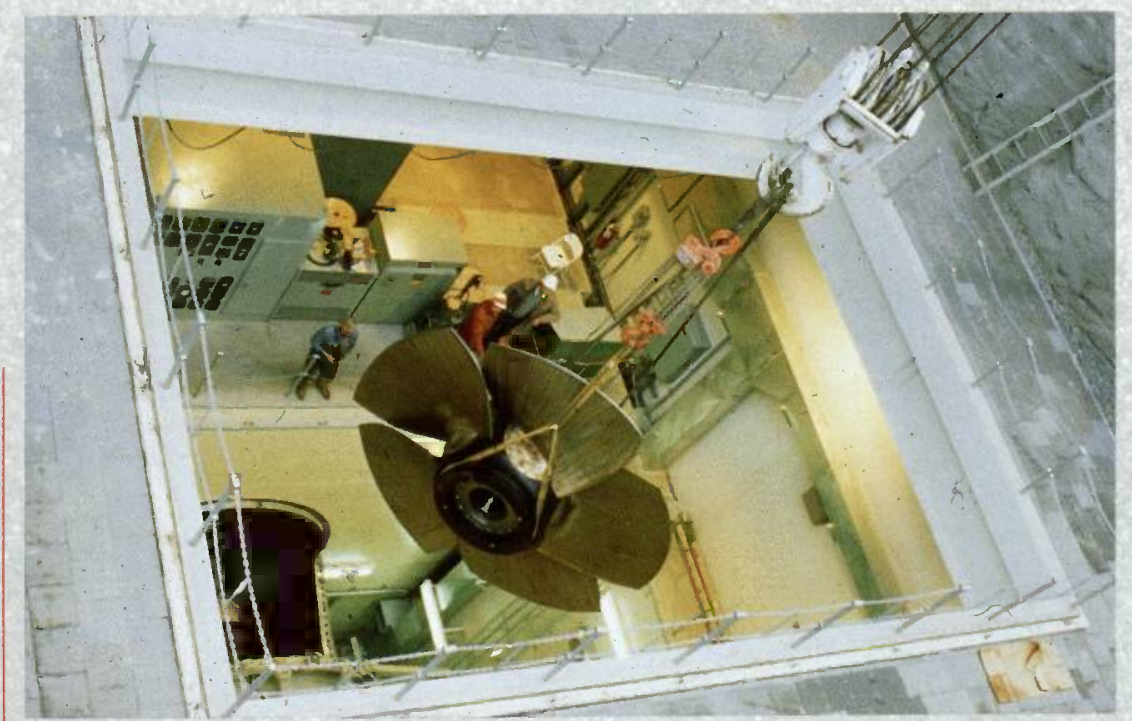

Construction crews lower a 40,700-pound runner assembly into position for installation at PEC Headworks Hydroelectric Project in Grant County. Washington. The 6.5-MW power plant will use irrigation water to develop 20 million kWh of power annually. 


\section{Generation and Power Systems}

On the Argentine/Paraguayan border, construction on the earthen and concrete works of the dams, dikes, spillways, and powerhouse of the $\$ 5$ billion Yacyreta Hydroelectric Project on the Parana River advanced on schedule last year. The work included closure of the main branch of the Parana River which is one of the largest such closures ever accomplished. Manufacturers also began fabrication of the 138-MW turbines and generators for the 2,760-MW project, the first unit of which is scheduled to come on line in early 1993.

In 1989, Harza returned to Priest Rapids and Wanapum, two hydroelectric projects that the company designed for the Grant County Public Utility District, Washington, in the 1960s, which provided for future generation expansion. In association with $\mathrm{CH} 2 \mathrm{M}$ Hill, Harza is reviewing and updating the feasibility studies for the expansion of hydroelectric generation at both facilities. The planned expansion of $640 \mathrm{MW}$ was never initiated due to reduced market demand during the 1980s. The current review is addressing any needed modifications to the plans in light of today's higher environmental standards.

Harza, in association with R.W. Beck, was retained by the Arizona Power Authority and the
Colorado River Commission to review Bureau of Reclamation plans and designs for a 500-MW expansion of the Hoover Dam power plant.

Field explorations for the foundations of the dams and dikes began in earnest last year on Oglethorpe Power Corporation's Rocky Mountain Project, a 760MW pumped-storage facility in northern Georgia. Construction also began on the site microwave system. The general construction contract bid documents were started and work on construction drawings will be initiated by the second quarter of 1990. Harza also generated computer models of the powerhouse and lower intake channel for stability analysis and structural design.

Harza research and development funds supported development of a powerful PC-based computer program designed to simulate the operation of complete river/ reservoir hydropower systems (RRHS). The RRHS model has been applied across the United States assisting hydro power regulators and owners, such as Central Maine Power and Wisconsin Electric, in optimizing power generation while maintaining instream flows for a variety of environmental and recreational purposes.
Harza's expertise in pumpedstorage generation was a major factor for the company's selection to provide technology transfer to China in the design of the large-diameter, high-pressure, reinforced-concrete manifold for the 1,200-MW Guangzhou Pumped Storage Project.

Harza also participated in a feasibility study with Jungwoo Engineering Company considering the development of the 1,000 MW Yangyang Pumped Storage Project for the Korea Electric Power Corporation (KEPCO). If built, the project will feature a design head of $780 \mathrm{~m}$, which would make it the highest head for any pumped-storage project in the world.

For Naperville, Illinois, Harza designed three 138-kV and one $34.5-\mathrm{kV}$ substations to assist the city in strengthening its distribution system. This was the first electrical design project to be fully implemented on Harza's Intergraph CADD system.

Last year continued to be a strong one for FERC relicensing activities. Harza and StetsonHarza assisted hydro power plant owners across the United States in relicensing applications encompassing over 70 dams and power plants from 0.25 to 100 MW. The services covered the full-range of licensing activities, including safety inspections; rehabilitation services; generation systems analyses; fisheries (Instream Flow Incremental Method) and recreation (Form 80) studies; license compliance; and a variety of economic studies and projections. As expected, environmental issues related to hydropower operations have become one of the most important aspects of current license applications. These issues are covered in the Environmental Sciences Section on page 13.

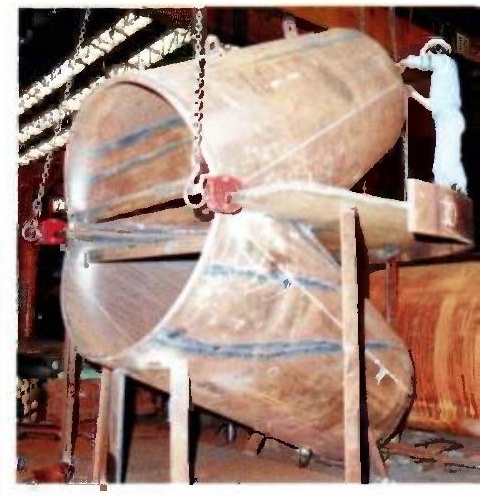

Construction is nearly complete on the 80-MW Kangneung Hydroelectric Project in Korea, which features a $15 \mathrm{-km}$ long power tunnel and a 600-m vertical shaft. The design of the steel penstock bifurcation (pictured) was a critical component to the success of the project. 


\section{Public Works}

In the Chicago area, the U.S. Army Corps of Engineers conceived a plan to develop surface reservoirs to collect storm water from the Metropolitan Water Reclamation District of Greater Chicago's (MWRDGC) TARP, which will help prevent flooding and decrease the annual cost of water damage in low-lying urban areas. Harza was retained in 1989 to study the feasibility of future expansion of these reservoirs to address the MWRDGC's need to prevent backflows into Lake Michigan of polluted storm water from the city's combined sewers.

By the end of 1989, work on the concrete structures, miter gate, and control features for the navigation lock at the Yacyreta Multipurpose Project was nearing completion. By mid1990 , assembly of the downstream miter gate will be complete along with primary electromechanical systems to provide for provisional operation of the 886-foot-long, 88-footwide lock while construction proceeds on the main project. Completion of the control house and operating systems and final assembly of the upstream wheel gate will be accomplished by mid-1991 to place the facility in full operation.
During 1989, the Harza team working at the proposed site of the first national nuclear waste repository in Nevada grew to 21 people, including specialists in the design and construction of underground tunnels and structures. Since the safety and security of the stored nuclear waste is the highest concern of the project, great efforts have been expended over the last year to develop new quality assurance procedures that will apply to all aspects of the project as it progresses from planning through construction. For example, Harza has been assisting during the development of prototype dry drilling techniques, which will be vital during site explorations to locate and identify potential perched groundwater. The identification of any sources of naturally occurring groundwater is crucial to the selection of the final site for the underground storage facility.

Harza began work on contract plans, specifications, and estimates for a section of the new Elgin-0'Hare Expressway, which will help reduce congestion on roads serving suburban communities northwest of Chicago

Designs include complete construction of a new 1.3 mile section of a four-lane, limitedaccess freeway; two, two-span composite steel plate girder bridges; a full diamond interchange; frontage roads; signage and signalization; a major crossroad realignment/relocation; as well as designs for widening an adjacent service artery. Plan preparation and geometric design are being performed using Harza's Intergraph CADD system.

In 1989, the joint-venture of Harza and James Montgomery continued providing construction management services to the National Organization of Potable Water and Sanitary Drainage (NOPWASD), for water supply and waste water treatment facilities for three cities in Egypt. Engineering services include review of designs, monitoring of construction, technology transfer for $0 \& \mathrm{M}$, certification of payments, and general contract administration.

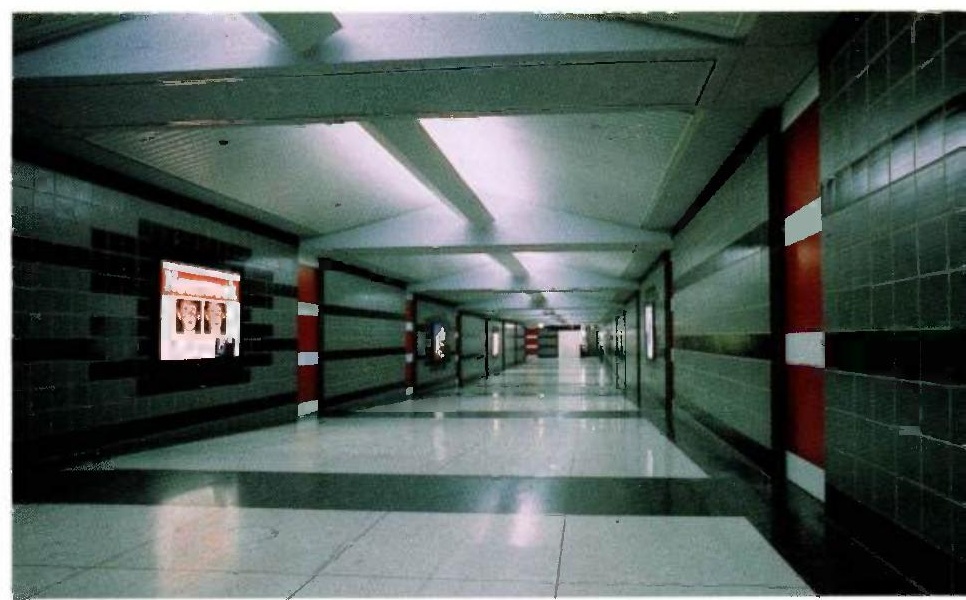

The new Harza-designed pedestrian/utility tunnel at O'Hare Airport in Chicago is open and in service, allowing passengers and airport personnel access to short-term outdoor parking facilities from the main terminal building. The location of the tunnel in a busy section of the airport crisscrossed by vital utilities, posed many challenges to Harza both during design and construction. 


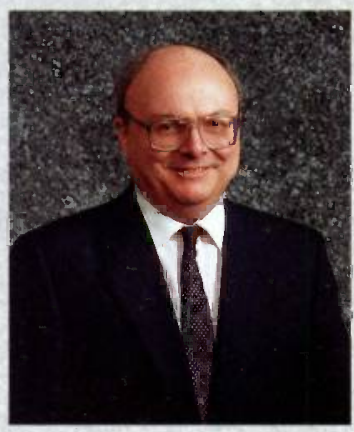

Richard L. Meagher Head, Planning and Licensing

Food crops are a nation's most basic natural resource. Harza has been involved on four continents assisting the governments of 39 nations in the planning, development, and maintenance of largeand small-scale agricultural projects. It is with great pride that among the company's many accomplishments,

Harza can claim a role in assisting the country of Bangladesh in planning for widespread development of irrigation and the realization of major gains in food grain production.

In the Bakel region of Senegal, Harza is assisting with the improvement and expansion of irrigation systems. Here, local farmers are being instructed by Harza's team leader on the requirements of a good irrigation water control structure.

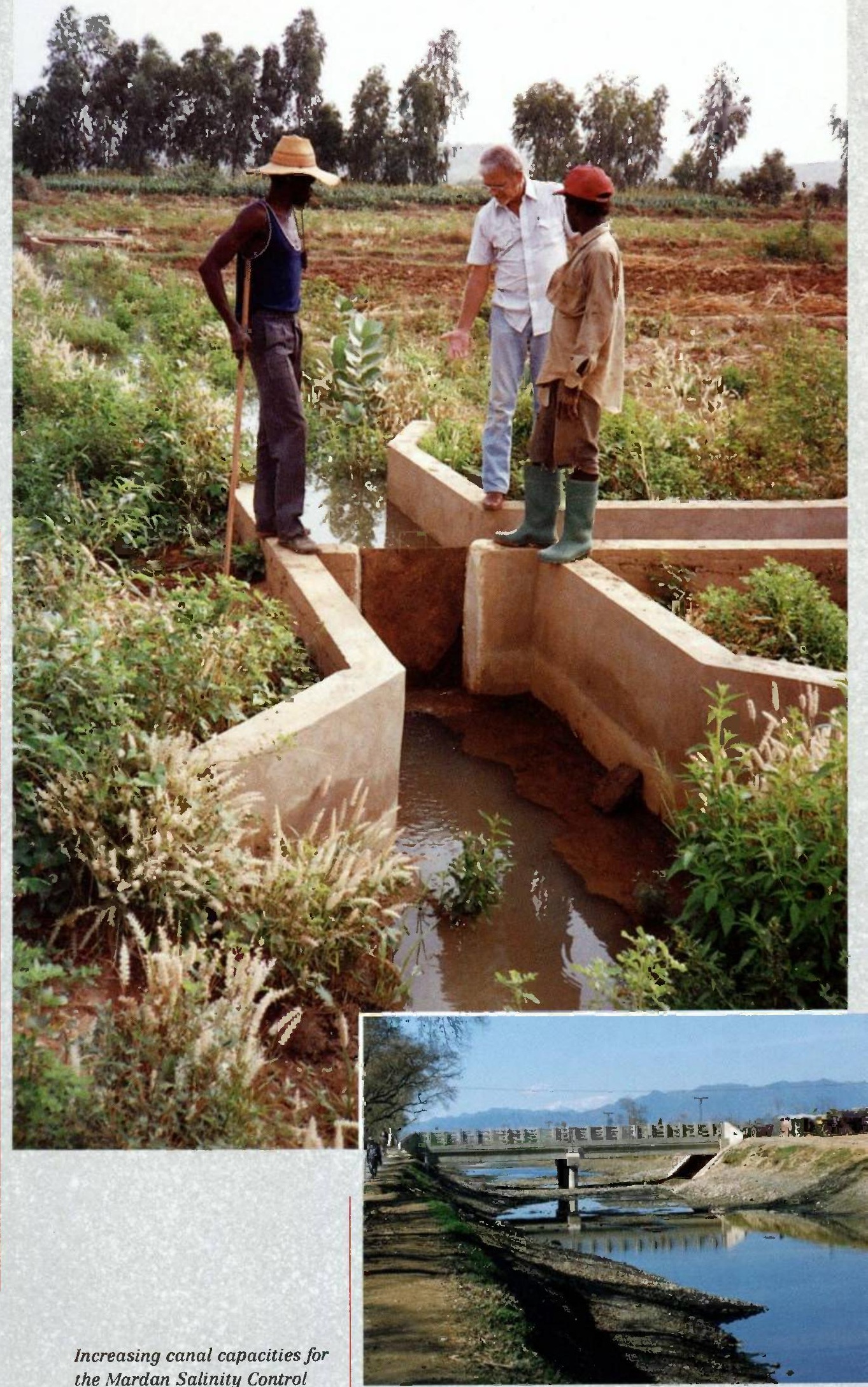

and Reclamation Project

(SCARP) required the design

and construction of new bridges,

such as this one pictured, over

the widened canals. 


\section{Agriculture and River Basin Planning}

Building on a 30-year history of successful service to the government of Pakistan, Harza continued or started work on five different projects which will help in the development and maintenance of irrigated land throughout the country. For the Water Sector Investment Plan, Harza is assisting WAPDA in the identification and prioritization of investment opportunities for the improvement and expansion of irrigation and drainage facilities Construction is advancing on drainage and irrigation system improvements for the Mardan SCARP, as well as training in effective means of utilizing the improved irrigation system. Harza also began work last year assisting the Federal Flood Control Commission to plan and design methods to prevent or minimize damage from storm flooding along the Indus and other rivers in Pakistan.

Harza is also playing an important role on a project in Egypt, the goal of which is to implement a computer-aided control system for over $31,000 \mathrm{~km}$ of irrigation canals along the Nile River Basin. The project will eventually monitor and operate over 560 pumping facilities and 22,000 control structures, and will help to minimize water waste throughout the system. Harza is involved with all aspects of the project which has included planning, field investigations, in- service training and technology transfer, and the specification and installation of meteor burst, VHF, and microwave telecommunication systems.

Construction is nearing completion on a major irrigation development project for the government of the Dominican Republic. The project includes construction and/or rehabilitation of land and water resources in the area. It will serve up to 29,118 hectares of irrigated farmland distributed over several regions of the country. The project has been divided into two subprojects which include construction of approximately $202 \mathrm{~km}$ of main and lateral lined and unlined canals, $102 \mathrm{~km}$ of drains, and $117 \mathrm{~km}$ of berms and service roads; and on-farm development requiring construction of $120 \mathrm{~km}$ of feeding and supply canals, and $109 \mathrm{~km}$ of drains. Harza provided assistance in planning, preparation of contract documents, final designs, and construction management.

In 1989, Harza provided assistance to the government of Indonesia for the development of small scale irrigation projects. These projects affected 25,000 hectares in three provinces in this 13,000 island archipelago. Sponsored by USAID, the project's goals are to diversify production, increase cropping intensity, and improve water reliability. Harza's assistance will also include studies to ascertain the economic viability of the projects.

Harza services were continued into a phase II project to update and expand the water sector master plan for Bangladesh. Planning has already contributed to a major milestone as the country is nearing self-sufficiency in food grain production. Under the second phase, emphasis is being given to assisting the government in the establishment of a permanent Master Plan Organization which will plan for efficient use of water in the agricultural and other sectors, and address conflicts between water users.

In India, Harza helped establish a program of in-service training in Integrated River Basin Planning and Management for professionals from the Central Water Commission (CWC), state irrigation departments, and other water sector agencies. Harza, Utah State University, and CES (Pvt) Ltd. of New Delhi developed the training program for the CWC's new Central Training Unit. Harza helped select and train teaching staff, procure facilities and equipment, prepare case studies based on local conditions, and conduct the initial series of three- to ninemonth courses and related U.S. study tours. Some 200 professionals will attend courses during the five-year program.

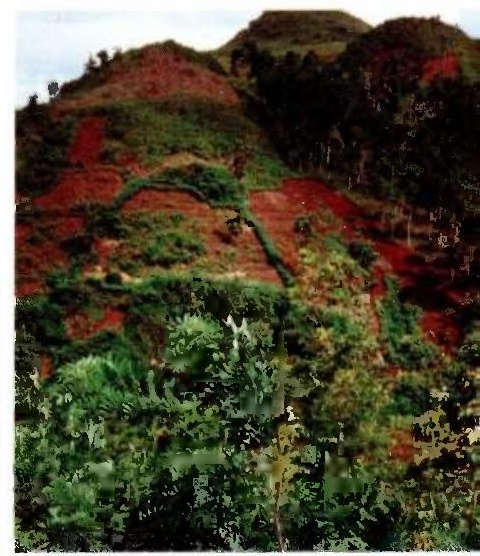

In many areas of Indonesia, good farmland is being subjected to unnecessary erosion. Harza is assisting the government to implement various methods of preventing this erosion as well as training local farmers in soil conservation and proper irrigation techniques. 


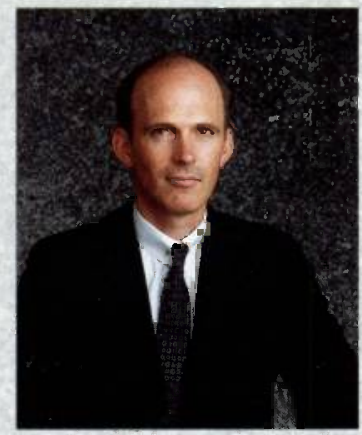

David R. Baier

Head, Special Projects

Harza's leadership in the rehabilitation of dams and hydroelectric projects is unprecedented and founded on the firm's 70 years of experience in the design and development of these types of projects. Rehabilitation expertise has become especially important today as regulations regarding all aspects of the safety and operation of dams and hydraulic structures have grown more stringent. Harza's Special Projects Department provides rehabilitation services through a staff of engineers and specialists experienced in all aspects of the design and operation of these projects.

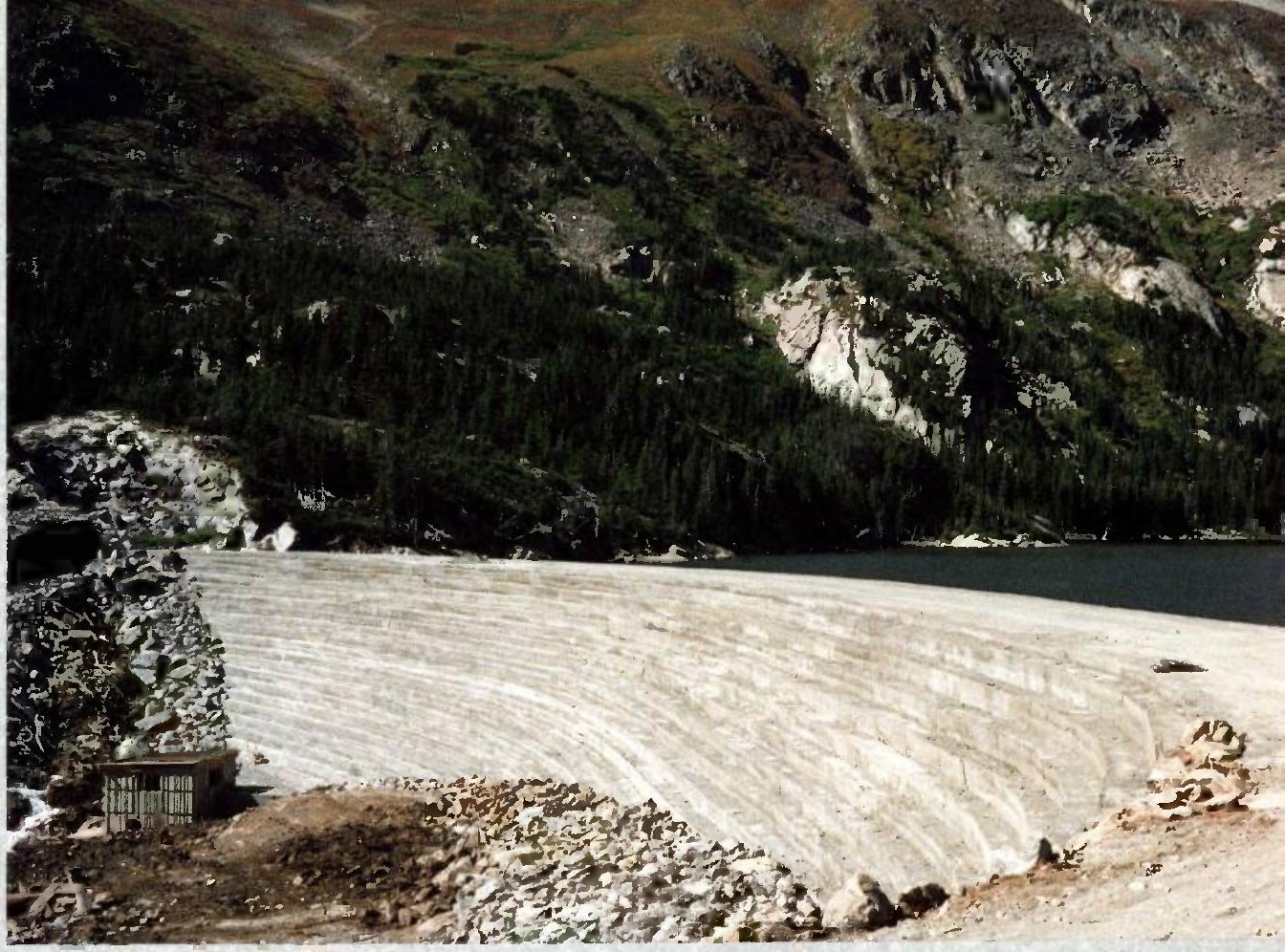

Responding to the client's need to address increased PMF safety requirements for the Goose Lake Dam in Colorado, Harza designed a unique soil-cement, cascade-type spillway which permits the dam to be overtopped safely during maximum flood.
After studying alternatives for the rehabilitation of Wissota North Dam in western Wisconsin, Harza proposed removing backfill from inside the slab and buttress structure and replacing it with concrete, thereby converting the structure into a gravity dam.

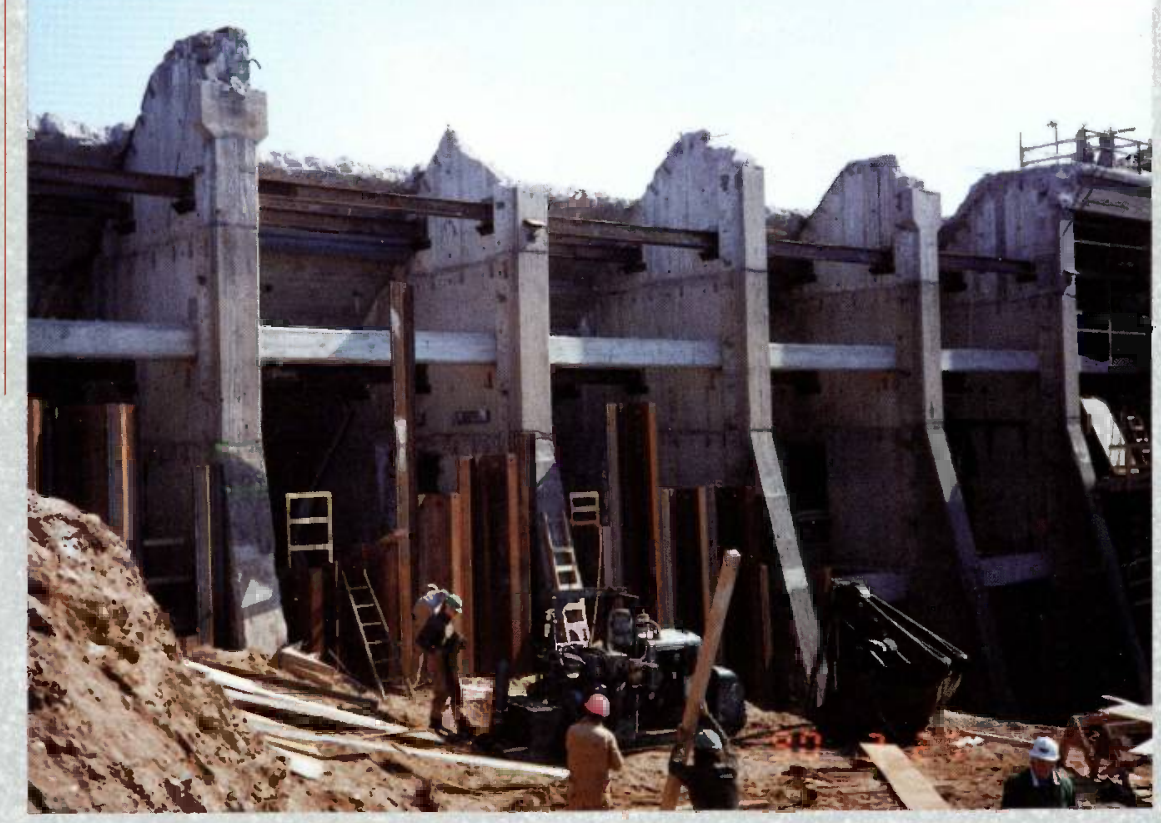




\section{Rehabilitation}

Designs, construction drawings, and specifications were completed in 1989 for the spillway expansion and rehabilitation for Wisconsin Electric's Brule Hydroelectric Project. As a result of Harza's inflow design flood studies, the client was able to obtain FERC approval for spillway capacity requirements substantially lower than initially required by FERC. Rehabilitation work on five of Brule's eight tainter gates, which included new concrete piers and sills, was substantially completed in 1989 . All work on the gates will be completed in 1990. The work includes incorporation of a minimum flow release structure in one of the remaining piers.

Construction of the emergency spillway designed by Harza for Boney Falls Dam was nearing completion by the end of the year. The unique design features a 500-foot-long RCC spillway controlled by a shallow, fourfoot-high earthfill fuse plug on top of the RCC structure. Five gravel-filled starter notches are provided through the earthfill to initiate spillway operation at the designed elevation. The new structure will allow safe passage of the FERC-approved inflow design flood.

Recent concerns about the safety of slab-and-buttress dams have prompted the review of such dams at several locations in
North America. The 60-foot-high Wissota Dam slab-and-buttress structure has been affected by the severe winter conditions near Eau Claire, Wisconsin, and was in need of rehabilitation. Northern States Power retained Harza to plan, design, and study alternatives for improvements to the dam, produce contract documents for repair, and provide technical assistance as requested during construction.

Harza continued work for Utah Power and Light as a result of FERC Part-12 safety inspections for Soda, Oneida, and Viva Naughton Dams. Field investigations, including core drilling and testing, led to the design of posttensioned anchors for Soda and Oneida Dams. Designs for raising the crest of the embankment at Oneida Dam were also completed in 1989, after PMF studies identified the need to increase the reservoir capacity to contain the necessary flood volumes. At Viva Naughton Dam, Harza addressed FERC concerns about possible seepage problems during flood surcharges and designed a fuse-plug spillway to accommodate discharges from the projected PMF. The client has also retained Harza to provide construction engineering services for all three projects.

For the city of Decatur, Illinois, Harza planned and designed the rehabilitation of two 233-feet- long, 5-feet-high, flap gates for the city's Main South Dam and Reservoir, which supplies domestic water to the area. The rehabilitation work also included the design and replacement of the aging electrical and hydraulic control systems.

Concerned about the safety and stability of a 140-year-old timber crib dam, a client in Massachusetts had retained Harza in 1982 to study rehabilitation or replacement options for the structure. Following Harza's recommendation, the client authorized Harza in 1989, to design a 9-foot-high, 165-footlong, ogee-crested, concrete weir which was built just downstream of the older dam as a replacement.

At Illinois Power's Clinton Power Station in Illinois, Harza planned and designed a program to dredge accumulated sediments from the facility's Ultimate Heat Sink. This 150 -acre reservoir. which is designed for use in an emergency shutdown of the power plant, was silting up more quickly than had been projected. Harza's services - which included specification of the dredging program, engineering design of a disposal facility, and assistance during construction - enabled Illinois Power to provide for their dredging needs for the next 50 years.

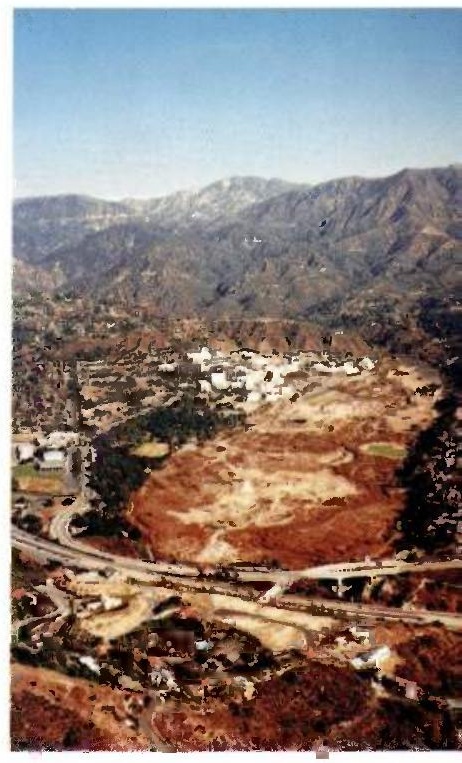

In California, the city of Pasadena retained Harza and another firm to study the feasibility of rehabilitating the Devil's Gate Dam and developing the area into a regional park with recreation facilities. 


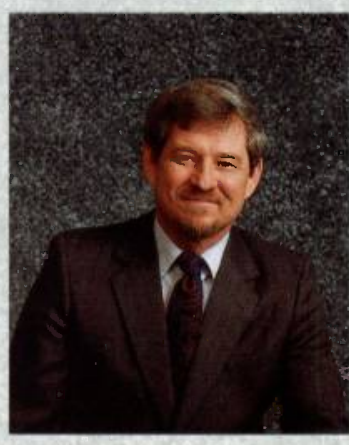

James H. Thrall

Head, Environmental Sciences

One way in which the growing concern over environmental issues both in the United States and around the world can be seen is in the doubling of the size of this department over the last two years.

Whether Harza addresses the regulatory compliance requirements, public access and recreation or the impact of flood control on fish habitat and food crop production, the company is committed to having in-house specialists with the expertise and experience to meet all clients' requirements.

Aerial view of the Rocky Mountain Pumped Storage Project in northern Georgia, showing the intake for the upper reservoir at the top right and the excavation for the 760-MW powerhouse below.

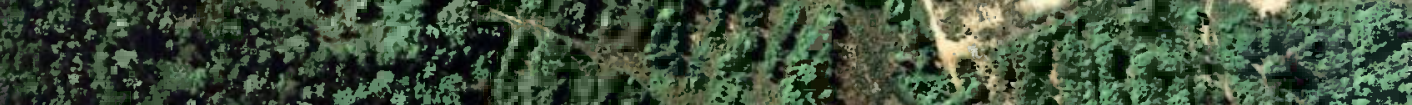

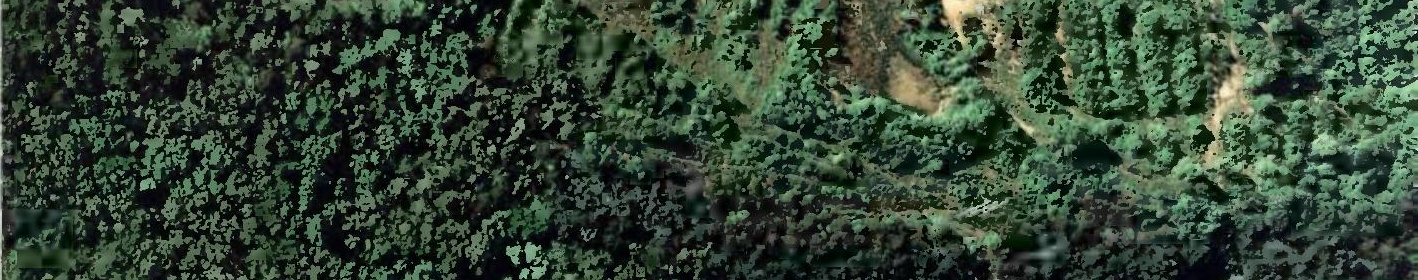

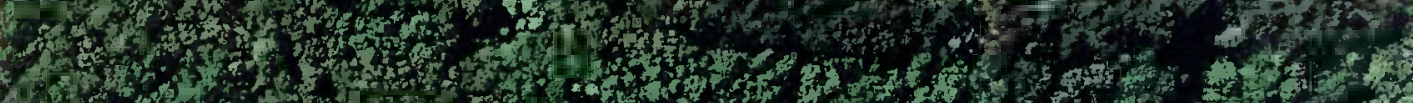

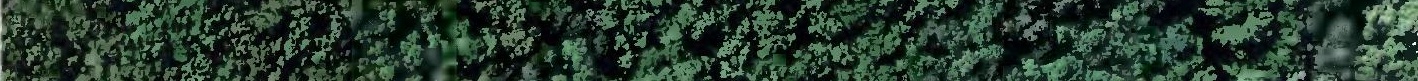
19.

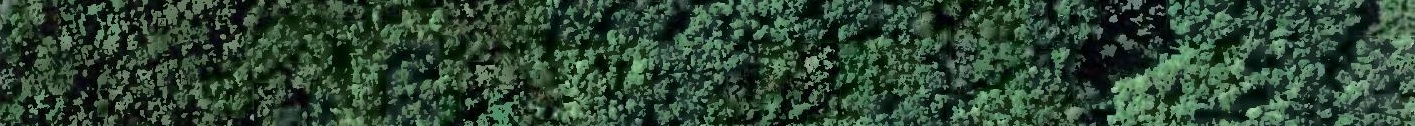

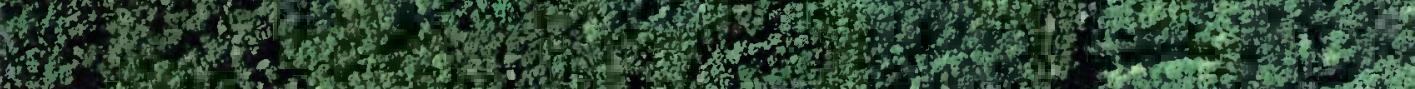

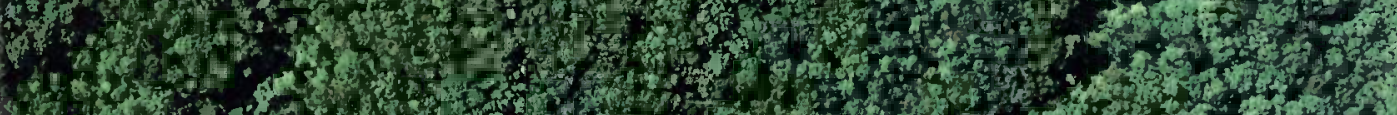

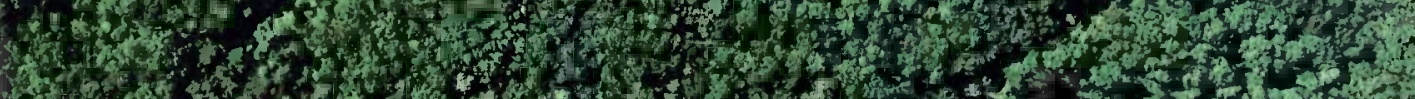

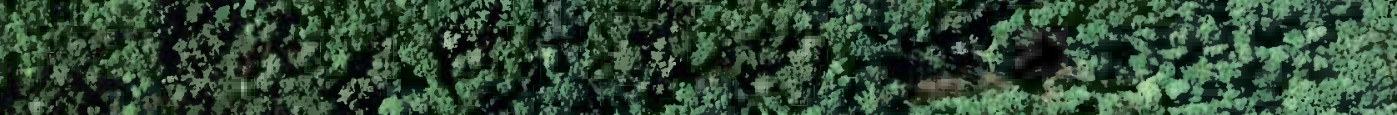

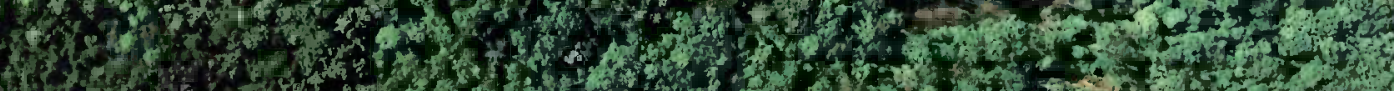

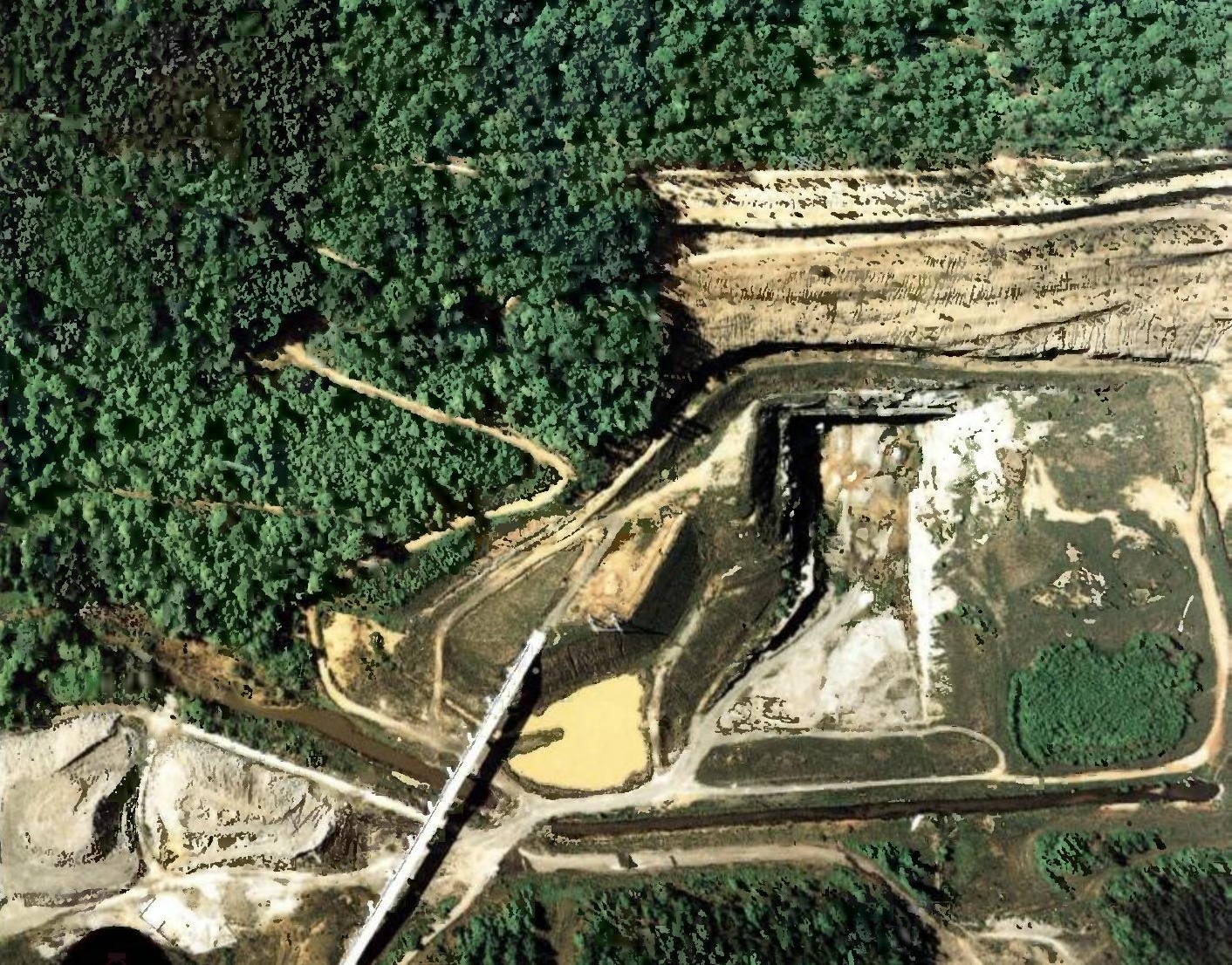




\section{Environmental Sciences}

In 1989, Harza began a baseline study of PCB contamination of air, water, biota, and sediment in the Hudson River in upper New York State. Retained by GE and working in close cooperation principally with the U.S. EPA and the New York State Department of Environmental Conservation, Harza performed field investigations to determine the seasonal levels of PCB contamination around the Ft. Edward PCB Remnant Deposits. Harza specialists used state-of-the-art monitoring techniques for the study, including multi-plate samplers, solventfilled dialysis bags, and in situ fish assays. Harza's involvement will extend through containment of the remnant sites and is expected to continue for the next two to three years.

Environmental compliance work for the construction of the Rocky Mountain Pumped Storage Project in Georgia also progressed. In 1989, Harza assisted Oglethorpe Power Corporation during transfer of existing permits from Georgia Power, including Corps of Engineers Section 404 , and in obtaining other needed permits. Harza reviewed existing water quality data, on-going field sampling, and lab procedures in compliance with federal and state requirements, and began refinement of the project clearing and recreation plans.
For Scott Paper, Harza negotiated with the FERC, U.S. Fish and Wildlife Service, and the Michigan and Wisconsin Departments of Natural Resources on behalf of the client to perform a year-long fish entrainment study as a condition to their FERC license application. The study will employ both netting and hydroacoustic sampling techniques and will gather comprehensive data on the numbers, species, and size of fish entrained.

Harza assisted Cooper Consultants in conducting studies for a flow management plan in the Upper Klamath River Basin in Oregon. The primary concern of the plan was to maintain flows to protect the habitat of two endangered species of fish inhabiting approximately 200 miles of stream. Study sites were selected on representative reaches for detailed investigation of flows versus habitat relationships using Instream Flow Incremental Methodology. Minimum flow requirements for protecting the endangered fish will be based on the results of the study.

On the Escanaba River in Michigan, Harza is conducting extensive environmental studies to support the relicensing of four dams and three powerhouses operated by Mead Paper. The studies include evaluation of wetlands utilization by bald eagles and waterfowl, estimation of fish entrainment mortality, analysis of water quality in the river and impoundments, and preparation of fish habitat maps for each impoundment and intervening river reaches.

Harza conducted environmental studies necessary to support an application for licensing of hydroelectric facilities at a water supply project on the Occoquan River near Washington, D.C. A major issue of the licensing process was the availability of suitable spawning habitat for anadromous American shad, blueback herring, and alewife upstream from the project. Habitat evaluations were performed to determine the need for fish passage facilities at the two dams which compose the project.

In Asia, Harza scientists assisted the government of Indonesia during a study of water and land use for small-scale irrigation on several islands in the archipelago. Environmental issues concerning water supply and quality, and increased cropping intensities are all under consideration.

In conjunction with investigations by other Harza specialists studying flood management methods in Bangladesh, environmental scientists are evaluating potential detrimental impacts flood control measures may have on the existing ecosystem. One important positive aspect of the perennial flooding is the role these waters play in sustaining flood plain fisheries. Fish are the second most important source of protein in the country after food grain, and changes to these fisheries could dramatically affect this resource.

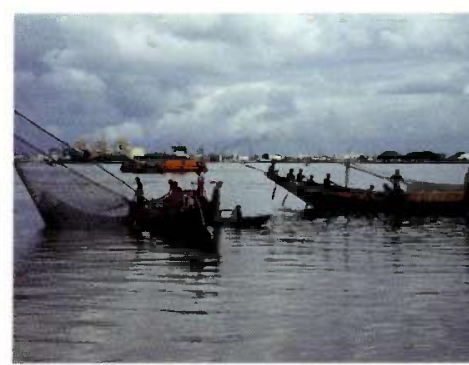

As Harza assists the government of Bangladesh in the investigation of various flood control measures, environmental specialists are studying potential adverse effects these controls would have on valuable fresh water fisheries. 


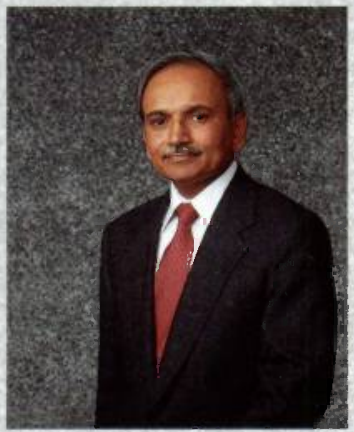

Jitendra R. Ghia President, HES

Founded in 1986, Harza Environmental Services (HES) has two primary objectives. The first is to provide clean, safe water supply to municipalities, and the second is to assist public agencies and private industry in the storage, treatment, and disposal of wastewater, and industrial and hazardous wastes. In the last four years, HES has expanded in step with the growing concerns of protecting and preserving the environment, and is prepared for the new challenges of the decade.

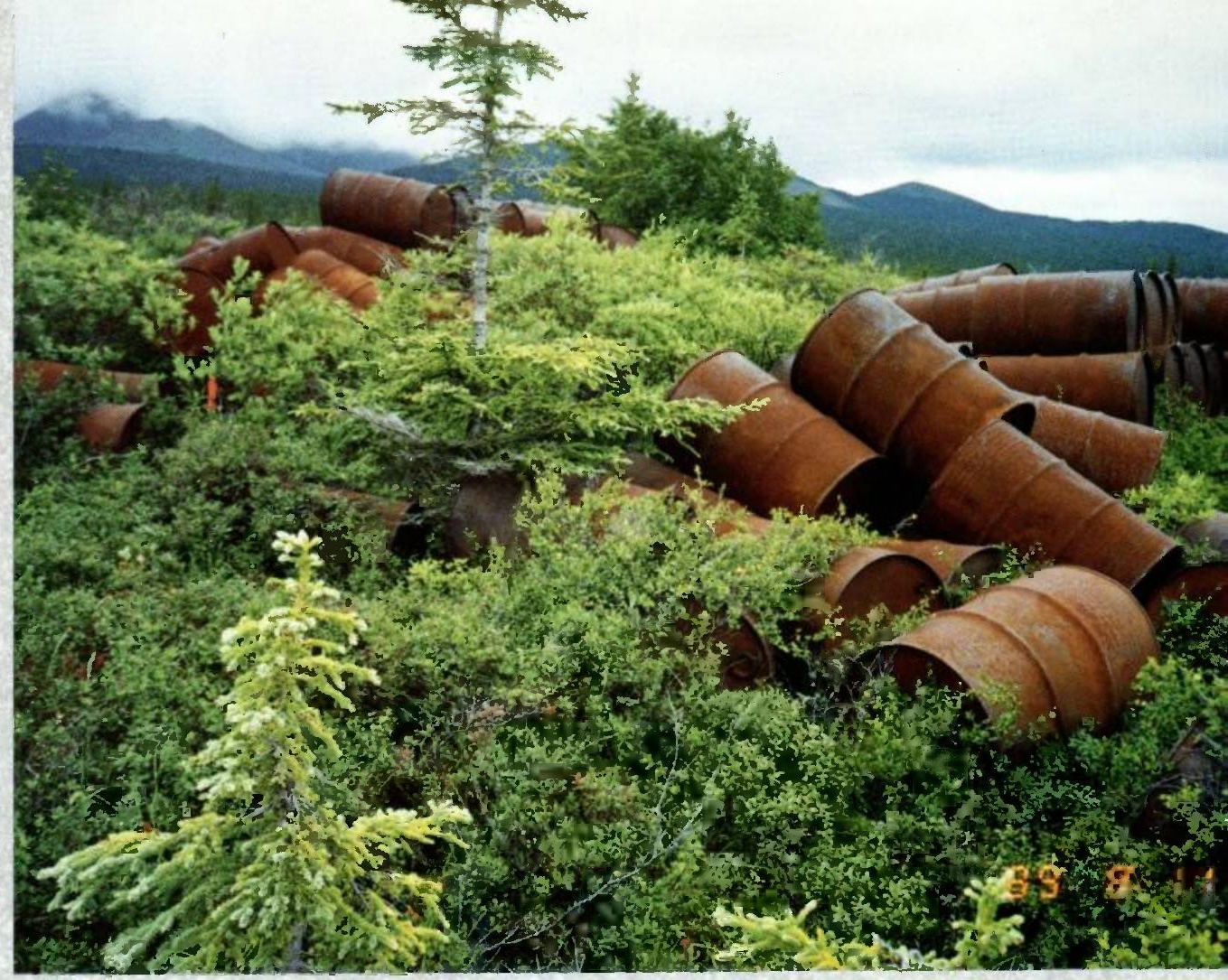

HES is working in cooperation with the U.S. Army Corps of Engineers to assess potential contamination of soils, sediments, and surface water and develop recommendations for remedial actions at abandoned military installations in Alaska's Seward Peninsula.

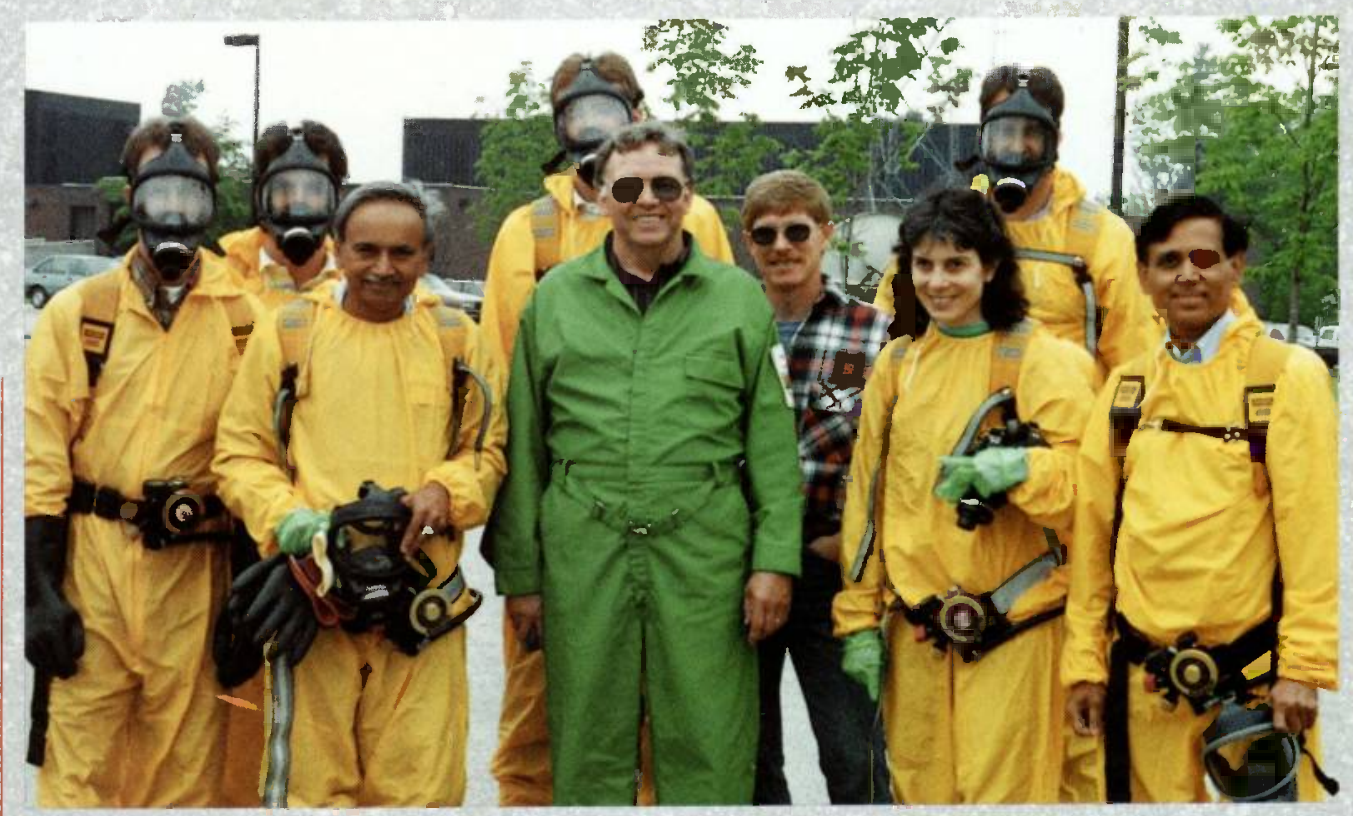

In 1989. HES conducted training in proper handling and field sampling procedures for drums and other hazardous materials to maintain the company's high record of safety. 
In 1989, HES continued work for Eli Lilly at two sites in the United States. HES conducted bench scale testing of in-situ bioremediation and began screening other remedial technologies to address groundwater contamination at one site. At the second site, HES is providing complete planning and engineering services for the closure of an ash incinerator landfill.

HES also worked on a Remedial Investigation/Feasibility Study for the Whitestown municipal landfill, an operating facility recently listed on New York's hazardous waste site register. HES' responsibilities include sampling and testing of groundwater, seeps, sediments, soils, and air; planning and design of the landfill cap; and evaluation of interim remedial alternatives.

HES is assisting the U.S. Army Corps of Engineers in the Defense Environmental Restoration Program by conducting remedial investigations at 13 abandoned military facilities in the Seward Peninsula, Alaska. Investigations involved the sampling and testing of soils, sediments, surface water, drums, tanks, and transformers to determine the level of contamination at those sites. HES is currently evaluating test results to provide recommendations for possible remediation.
HES performed technical review of the existing landfill design of the Phase III Municipal Landfill for the city of Ann Arbor, Michigan. HES recommended suitable liner material following leachate compatibility testing, and completed the initial slurry wall design.

HES, under contract with the Illinois Environmental Protection Agency, provided technical support for a state superfund mobile incineration site in southeast Chicago. HES monitored the excavation of contaminated soils and verified permit conditions during site operations.

In 1989, HES completed design work on improvements to the water supply system for the village of Oak Brook, Illinois. The work included the planning, design, and services during construction for a 13 milliongallon-per-day booster pumping station; design for three pressureadjusting stations; site planning for a four-million-gallon storage reservoir and pumping station; and planning and design for connections to the DuPage Water Commission.

Since coming on-line last July, a HES-designed water treatment plant has been operating successfully for the DuPage County Department of Environmental Concerns. Capable of treating four million gallons per day, the facility uses an innovative process including continuous backwash filters and the latest technology in reverse osmosis to remove iron and dissolved solids from the system's groundwater supply. Treated water from the plant is stored in a 500,000 gallon reservoir and delivered to the distribution system by an 11-mgd variable frequency driven pumping station, also planned and designed by HES

HES and Harza are also working together under funding by the Inter-American Development Bank to provide consulting services during preparation of a master plan for the expansion and upgrading of the water supply and wastewater treatment systems in the Central Littoral of Venezuela. The study will identify a plan for increasing surface water supply, improving water distribution/treatment, and upgrading wastewater collection/disposal.

HES involvement in the multimillion dollar plan to address flooding problems in and around the village of Arlington Heights, Illinois, continued through 1989. HES was responsible for about two miles of channel improvements upstream of the 540 -acrefoot detention basin, including permitting assistance, planning and design of channel widening and gabion walls, and assistance during construction.
HES was retained by the village of Northbrook, Illinois, to begin preliminary design of improved and expanded raw water supply and treatment facilities in the community.

For the city of Evanston, Illinois, HES developed a plan for mitigation of basement flooding utilizing the concept of partial separation of sanitary and storm flows.

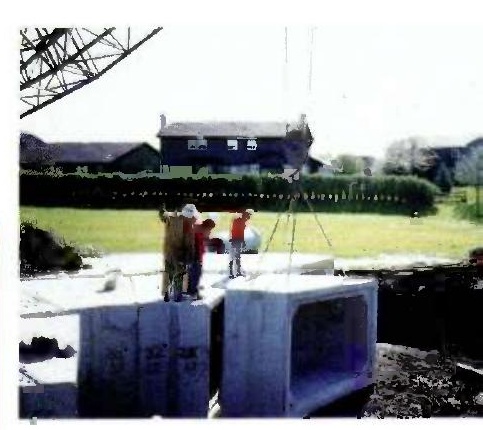

Workers are installing box culvert sections as part of the Harza-designed McDonald Creek flood control reservoir and channel improvements in Arlington Heights, Illinois. 
Stetson-Harza, a wholly owned subsidiary of Harza Engineering, is an architectural, engineering, planning, and construction management firm with corporate headquarters in Utica, New York. Over the past 26 years, the company, headed by President John B. Stetson, has provided services to a diverse group of national and international clients in industrial, utilities, governmental, military, health care and educational markets.

If there was a theme for the kinds of projects Stetson-Harza worked on in 1989, it would focus on the growing concerns, both in the public and private sector, about the rebuilding of our nation's infrastructure and preservation of the environment. For example, the team of StetsonHarza, Harza Engineering, and Hazen and Sawyer is undertaking a $\$ 155$ million water supply "mega-project" for the Orange County Water Authority in Orange County, New York, to accommodate the county's rapid growth and development

For the New York State Department of Transportation, StetsonHarza is designing interchanges, accesses, and bridges. This project is part of a statewide rebuilding program for roadways and bridges.

Final design for a 34-milliongallon-per-day water filtration plant on which Stetson-Harza worked as a program engineer was successfully completed for the City of Utica, New York. Construction of the plant, which will serve 135,000 residents in the greater Utica area, will begin in 1990.

In 1989, environmental protection issues were a paramount concern among clients. StetsonHarza is working with industrial clients to reduce environmental and workplace hazards at the source. "Source reduction", as espoused by Stetson-Harza's process, facilities, and environmental engineers, is the path chosen by an increasing number of clients to respond to government environmental regulations, economic imperatives, and survival realities.

For General Motors, StetsonHarza is preparing a database of oil usage and disposal practices. The proposal includes recommendations for re-refining oil for reuse at six GM Hydramatic Division plants. In addition, Stetson-Harza is implementing its study for a resin plant to reduce the emission of organic vapors.

The process engineering group also completed a study for Nabisco Brands, Inc. for the modernization of a Houston, Texas, bakery; provided fullservice engineering for the production of two organics inter- mediates for Sterling Organics; and is designing a state-of-theart pigment manufacturing plant for a subsidiary of a major international company.

Stetson-Harza continues to be a leader in serving New York State school districts. When the Carthage School District had to provide for a threefold increase in enrollment resulting from substantial expansion of the nearby military base at Fort Drum, Stetson-Harza designed an addition to the existing 250student Black River Elementary School. The new addition architecturally complements the original 1928 structure and provides ample new space to accommodate updated educational programs and the enlarged student body. Students in the combined Cherry Valley-Springfield School District now occupy a school that sets new standards for the integration of grades kindergarten through 12 . The school was completed in 1989.

In Rome, New York, the firm has completed the schematic design for a 275,000-square-foot high school which is the largest single school building that StetsonHarza has completed. In Utica, the firm was retained to prepare the district-wide consolidation plan for the city school district.
Preferred Mutual Insurance Company-Rich, cherry veneer paneling, linen wall covering. and glass block accent lites enhance the board room of Preferred Mutual's corporate headquarters in New Berlin, New York. The new corporate complex, which doubles the size of the former facility, links an original 1916 brick headquarters building and several subsequent additions with a new 41,000-sq.-ft. space. Remodeling of the existing space, design of the new addition, and construction management services were all provided by Stetson-Harza.

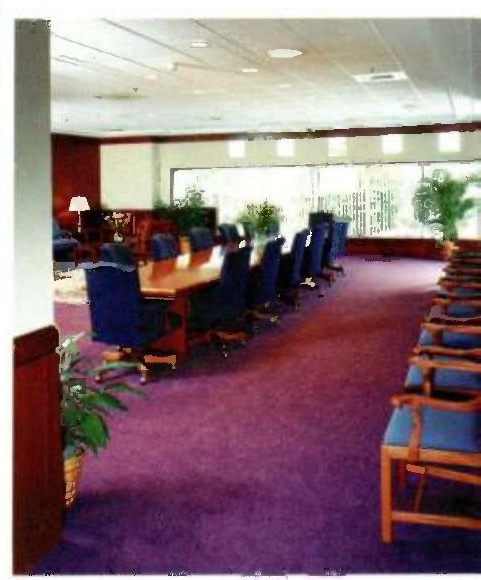


New York State Electric \& Gas Corp-—This state-of-the-art energy control center contains a control room; computer and systems support spaces; display and database maintenance, and communication facilities; and associated support, office, and circulation areas.
The \$45-million Utica plan in-

cludes the renovation and

expansion of nine existing schools

and the construction of two

new schools. Stetson-Harza will provide construction manage-

ment services for the first phase of the project.

Driven by rapidly shifting socioeconomic, technological, and demographic forces, the health care industry is witnessing dramatic changes in the delivery of patient services, marketing, and facility design. Some of the most noticeable ramifications have been the widespread increase in outpatient ambulatory services, long-term elderly care, skilled nursing facilities, and congregate care centers. Stetson-Harza has been monitoring these trends and has established responses to these new market demands. Reflective of these efforts is the design work for St. Luke's Memorial Hospital Center in Utica, New York. During 1989, project work included expansion and renovation for a new ambulatory care center; an addition to the skilled nursing facility; the incorporation of a new mental health unit; and, in the planning stages, the expansion/renovation for maternity care, medical/ surgical bed expansion, and a physicians office building, including a parking structure.

Stetson-Harza continues offering extensive experience and service capabilities to the utility industry. In 1989, the firm provided full planning, architectural, and engineering services for a 50,000-square-foot energy control center for New York State Electric and Gas Corporation in

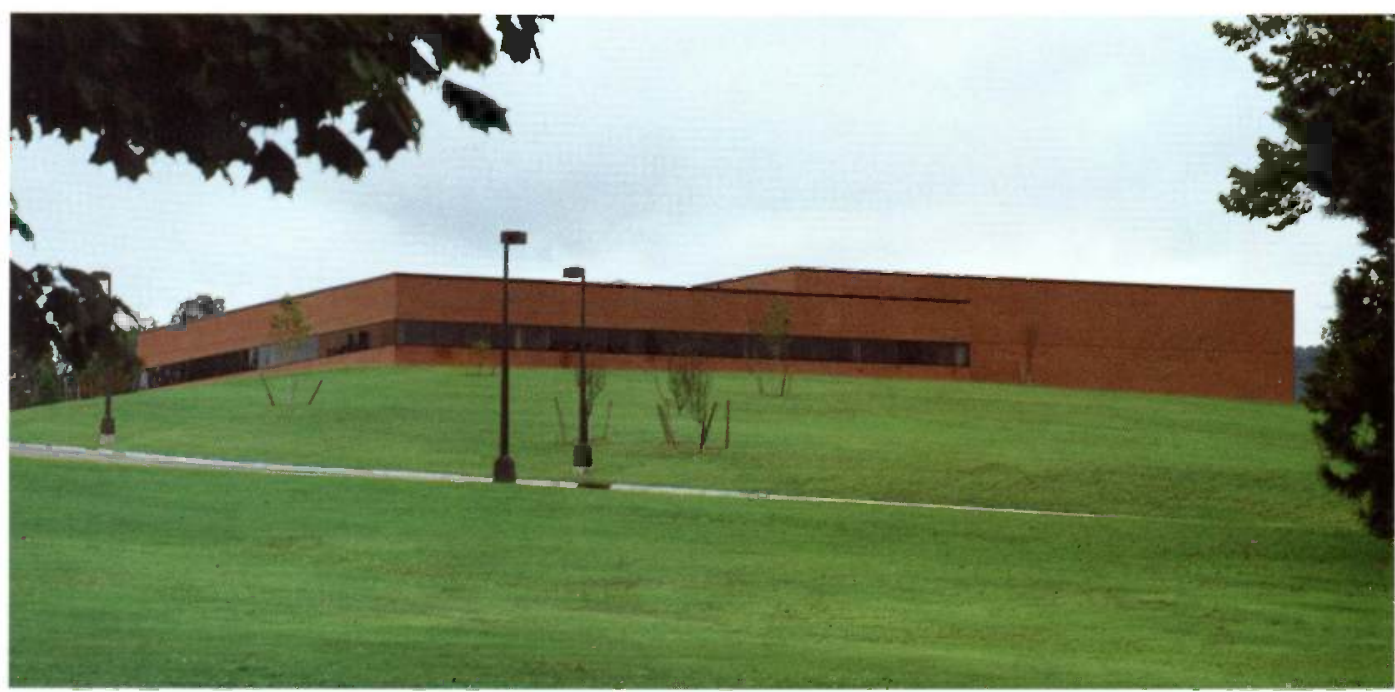

Binghamton, New York. The project also included development of a total site plan and traffic study to determine the capacity of adjoining roads and intersections.

Design services were provided to Niagara Mohawk Power Corporation for a planned 60,000-square-foot, two-story office building and a smaller two-story cafeteria, both part of the Nine Mile Point Nuclear Complex in Oswego, New York. Master site planning for Philadelphia Electric Company, completed in 1989, was StetsonHarza's largest master planning project to date for the nuclear energy industry. Planning for both the Peach Bottom Atomic

Bristol-Myers Squibb-Shown here is the batch reactor area in Bristol-Myers Squibb's $\$ 40$ million bulk pharmaceutical chemical plant in Barceloneta, Puerto Rico. Completion of the fast-track project in 1989 was an important milestone for the client and for Stetson-Harza's process engineering group.

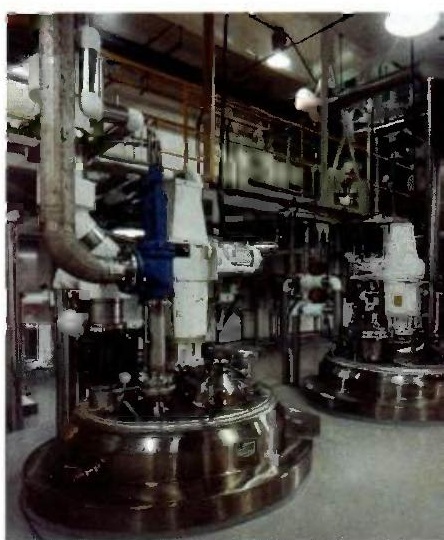




\section{Harza Companies Representative List of Clients in 1989}

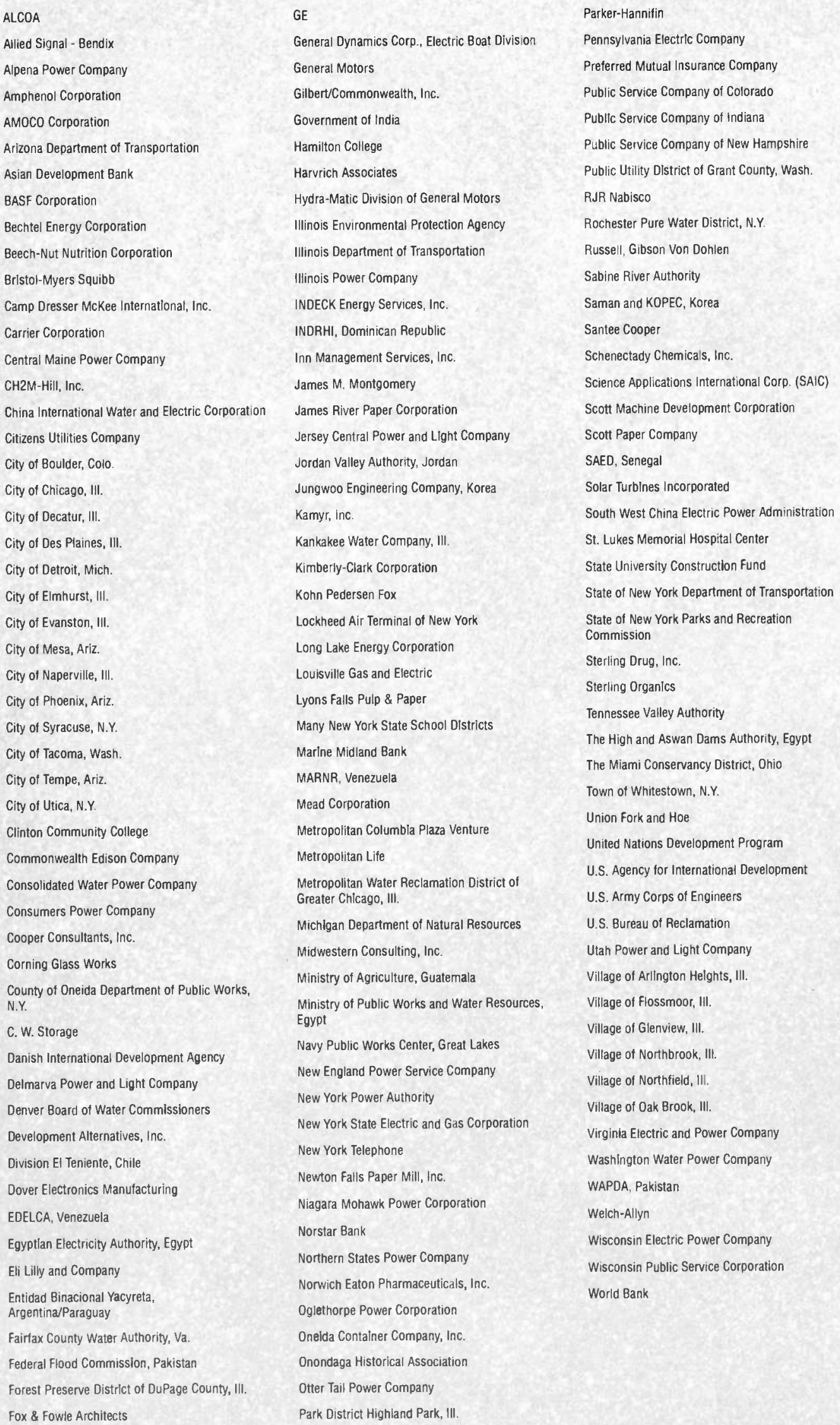




\section{Directors of Harza Engineering Company and Managers of Harza Engineering Company International}

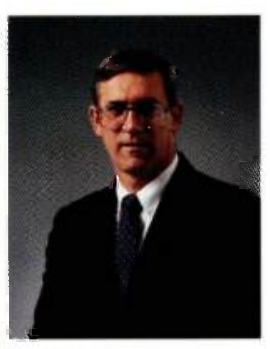

Walter J. Bogdovitz

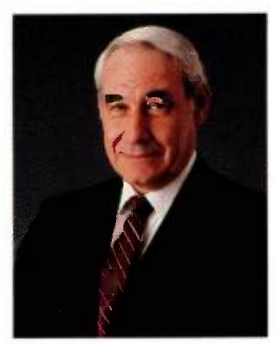

Donald J. Duck

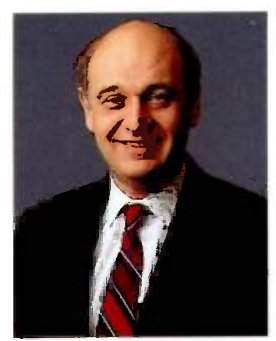

Ernest R. Hoelterhoff

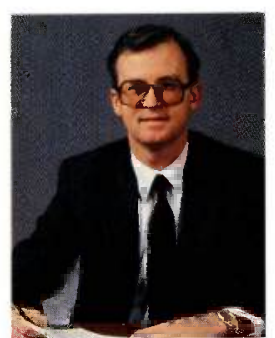

James T. Passage

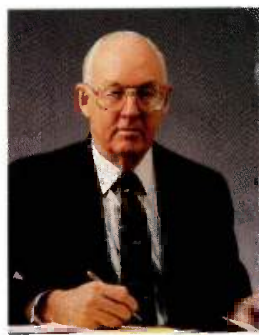

Russell Roddy, Jr

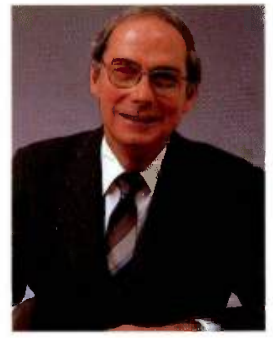

John A. Scoville

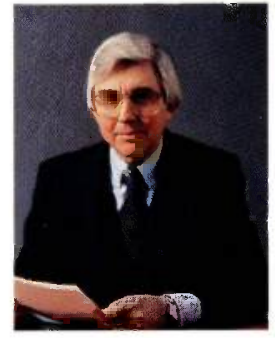

Robert H. Staplin

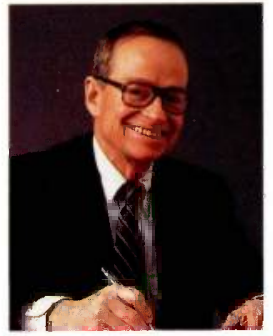

John B. Stetson

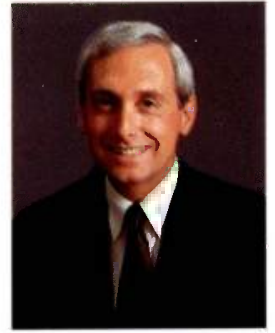

Glenn S. Tarbox

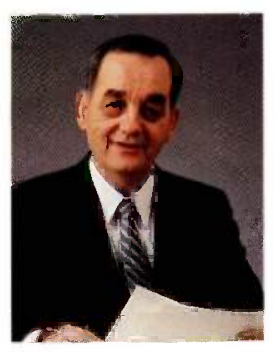

Roman P. Wengler

\section{Harza Engineering Company-Officers}

Brian A. Anthony

Rimas J. Banys

Walter J. Bogdovitz

William T. Bristow

Henry $\mathrm{H}$. Chen

Peter J. Conroy

Donald J. Duck

Yoneo Fukuda

Hans Hasen

Sean Hastings

Ernest R. Hoelterhoft

Jack $C$. Jones

David E. Kleiner

Richard L. Meagher

Eduardo A. Mellado
Edgar T. Moorē

James T. Passage

Leo A. Polivka

James $C$. Ringenoldus

Russell Roddy, Jr.

John A. Scoville

Robert H. Staplin

John B. Stetson

Glenn S. Tarbox

Jan A. Veltrop

Roman P. Wengler

Arvids Zagars

Vincent J. Zipparro

Leonard E. Zak

\section{Harza Engineering Company International-0fficers}

Refaat A. Abdel-Malek

Rimas J. Banys

Walter J. Bogdovitz

Donald J. Duck

Ernest R. Hoelterhoff

Richard L. Meagher

Eduardo A. Mellado

James T. Passage
James C. Ringenoldus

Russell Roddy, Jr.

John A. Scoville

Robert H. Staplin

John B. Stetson

Glenn S. Tarbox

Roman P. Wengler

Vincent J. Zipparro

\section{Stetson-Harza, Inc.-Officers}

Francis W. Byszewski

James H. Gwise

Frederick J. Kircher

Robert L. Manning

Anthony C. Martino

Thomas J. O'Shea

James T. Passage

R. Dale Reeves
Ernest F. Slocum

John B. Stetson

William H. Taylor

J. Michael Van Strander

Donald C. Wilhelm

John D. Williams

Leonard E. Zak
Harza Environmental Services, Inc.-Officers

Jitendra R. Ghia

Ashok L. Lagvankar 


\section{The Harza Companies}

Projects that protect and improve the environment

\section{United States}

\section{Regional Offices}

Colorado: 7979 East Tufts Avenue

Parkway, Suite 303

Denver, Colorado 80237

(303) $779-4830$

Oregon: 11675 SW 66th Avenue

Portland, Oregon 97223-8531

(503) 684-2701

\section{Subsidiaries}

Stetson-Harza, Inc.

185 Genesee Street

Utica, New York 13501

(315) 797-5800

Stetson-Harza, Inc.

250 Jordan Road

Troy, New York 12180

(518) 283-8080

Stetson-Harza, Inc.

Concord Center

10 Ferry Street

Suite 310

Concord, New Hampshire 03301

(603) 226-2888

Harza Environmental Services, Inc.

150 South Wacker Drive

Suite 1200

Chicago, Illinois 60606-4288

(312) $855-3300$

\section{Worldwide}

Harza Engineering Company:

Santo Domingo, Dominican Republic; Alexandria, Giza, Cairo, Egypt; New Delhi, Pune, India;

Jakarta, Indonesia; Amman, Jordan; Islamabad, Pakistan; Bakel, Senegal

Harza Engineering Company International L.P.: Buenos Aires, Ituzaingó, Argentina; Dhaka, Bangladesh; Chengdu, China; Guatemala City, Guatemala; Kingston, Jamaica; Amman, Jordan; Lahore, Peshawar, Pakistan; Asunción, Ayolas,

Paraguay; Caracas, Venezuela

Harza Canada, Inc.:

Toronto, Ontario, Canada

\section{HARZA}

Harza Engineering Company

Consulting Engineers

150 South Wacker Drive

Chicago, Illinois 60606-4288

(312) $855-7000$

Fax (312) 236-8010

Telex 25-3540 


\section{REPRESENTATIVE \\ EXPERIENCE IN ASIA}

Project and Location

Client

Services

Bangladesh

Small Scale Irrigation

Asian Development Bank

P

Sector

Improving Water Sector

Plan

World Bank

$\mathrm{P}$

Work Bank

P,T

Plan

China

Tianshengqiao Project

Ministry of Water Resources and

$\mathrm{T}$

Basuo and Dawan Dams

Electric Power

China International Water and

R,T,E,P

Ertan Hydroelectric

Project

Electric Power

Southwest China Electric Power Ad-

$\mathrm{R}, \mathrm{D}$

ministration

Ministry of Water Resources and

$\mathrm{P}, \mathrm{R}$

Electric Power

Guangxi Electric Power Bureau

$\mathrm{D}, \mathrm{C}, \mathrm{R}$

Project

India

Review of Pump Tur-

Damodar Valley Corporation

$\mathrm{R}$

bine Tender

P - Planning

R - Review

D - Design

$\mathrm{T}$ - Technical Assistance

C - Construction Services

E - Evaluation 


\section{REPRESENTATIVE \\ EXPERIENCE IN ASIA}

Project and Location

Services

India (cont'd)

India Dam Inspections

World Bank

$\mathrm{T}$

Hydrology/Hydraulics

Standards

Tamil Nadu Water Re-

United Nations Development Pro-

$\mathrm{P}$

sources Management

Study

Water Resource Systems

USAID/Government of India

P,T

Planning and Managegram

ment

Indonesia

Medan Electric Power

Rehabilitation

National Electric Company

P,C,D

Pekalen-Sampear

Rehabilitation Project

Ministry of Public Works and

$\mathrm{D}, \mathrm{C}, \mathrm{P}$

Electric Power

Rehabilitation and

Ministry of Public Works and

$\mathrm{D}, \mathrm{P}$

Extension Irrigation

Electric Power

Perusahan Umum Listrik Negro

$\mathrm{P}$

Electric Power - Long
Range Planning Study

P - Planning

D - Design

R - Review

$\mathrm{T}$ - Technical Assistance

C - Construction Services

E - Evaluation

900726

A900032P REA

$-2-5$ 


\section{REPRESENTATIVE \\ EXPERIENCE IN ASIA}

Project and Location

Indonesia (cont'd)

Hydro Development to

Freeport, Indonesia

$\mathrm{P}$

Copper Mine

\section{Korea}

Upper South Han River

Saman Engineering Company for

$\mathrm{P}, \mathrm{E}, \mathrm{T}$

Basin Hydroelectric

Korea Electric Power Corporation

Power Feasibility Studies

Kangneung Hydroelectric

Power Plant Project

Kangneung Hydro-Metal

Works

Nak Dong River

Barrage

Saman Engineering Company for

$P, D, E$

Korea Electric Power Corporation

Korean Heavy Industries and Con-

D struction Company Ltd.

World Bank, for Industrial Sites and

P,D,T

Water Development Corporation

\section{Sri Lanka}

Irrigation System Man-

Consortium for International Devel-

$\mathrm{T}$

agement

opment

Taiwan

Mingtan Pumped-Stor-

age Project

Sinotech Engineering Consultants

P

P - Planning

D - Design

R - Review

C - Construction Services

$\mathrm{T}$ - Technical Assistance

900726

A900032P REA 


\section{REPRESENTATIVE \\ EXPERIENCE IN ASIA}

Project and Location

Client

Services

Thailand (cont'd)

Mingtan Penstock

Taiwan Power Company

E,T

Bifurcation Configura-

tion

Project Management

Logistics Services

Provincial Electricity Authority

$\mathrm{P}$

Water Resources Man-

National, Economic and Social Devel-

agement Organization

opment

Study

Review Feasibility

Studies for Nam Mun

Royal Irrigation Department

D,C

Dam

Water Supply for Irrigation at Nam Mun Dam

Royal Irrigation Department

P,D,C

P - Planning

D - Design

C - Construction Services

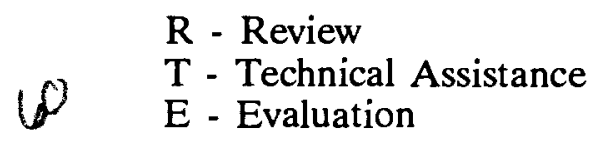

900726

A900032P REA

$-4-$ 


\section{CONSULTING ASSIGNMENTS WHICH BEST ILLUSTRATE QUALIFICATIONS}

The following information should be provided for each reference project in the format indicated below:

\begin{tabular}{|c|c|c|c|}
\hline \multicolumn{2}{|c|}{$\begin{array}{l}\text { Project Name: } \\
\text { Small Scale Irrigation Management }\end{array}$} & \multicolumn{2}{|c|}{$\begin{array}{l}\text { Country: } \\
\text { Indonesia }\end{array}$} \\
\hline \multicolumn{2}{|c|}{$\begin{array}{l}\text { Project Location Within Country: } \\
\text { Jakarta }\end{array}$} & \multirow{2}{*}{\multicolumn{2}{|c|}{$\begin{array}{l}\text { Professional Staff Provided } \\
\text { No. of Staff: } \\
\text { No. of Man-months: } 140.0\end{array}$}} \\
\hline $\begin{array}{l}\text { Name of Client: } \\
\text { USAID/Jakarta }\end{array}$ & & & \\
\hline $\begin{array}{l}\text { Start Date (month/year): } \\
\text { August } 1987\end{array}$ & $\begin{array}{l}\text { Completion Date (month/year } \\
\text { April } 1990\end{array}$ & & $\begin{array}{l}\text { Approximate Value of Services: } \\
\$ 5,027,888\end{array}$ \\
\hline \multicolumn{2}{|c|}{$\begin{array}{l}\text { Name of associated firm, if any: } \\
\text { DAI, GEI, Wiratman and Assoc. }\end{array}$} & \multicolumn{2}{|c|}{$\begin{array}{l}\text { No. of Man-months of professional } \\
\text { staff provided by associated firm: } \\
329\end{array}$} \\
\hline \multicolumn{4}{|c|}{ Senior Staff involved and functions performed: } \\
\hline \multicolumn{4}{|c|}{$\begin{array}{l}\text { R. D. Meredith - Project Manager } \\
\text { R. C. Rudberg - Area Manager } \\
\text { B. A. Anthony - Project Group Manager }\end{array}$} \\
\hline
\end{tabular}

Detailed Narrative Description of Project \& Services Provided:

Harza has been retained to provide Technical Assistance services for engineering and related institutional support to the Government of Indonesia for the development of small scale irrigation systems. For these services, Harza will provide leadership, management, advisory, and a wide range of technical services through teams located in three different provinces to work with the Provincial Public Works units to carry out reviews, planning, design, and construction of irrigation systems.

This will be accomplished by providing an integrated team composed of personnel from Harza Engineering Company and personnel from Harza's associated subcontractors, Development Alternatives Incorporated (DAI) of Washington, D.C., Global Exchange Incorporated (GEl) of Xenia, Ohio, and Wiratman and Associates of Jakarta, indonesia. 


\section{CONSULTING ASSIGNMENTS WHICH BEST ILLUSTRATE QUALIFICATIONS}

The following information should be provided for each reference project in the format indicated below:

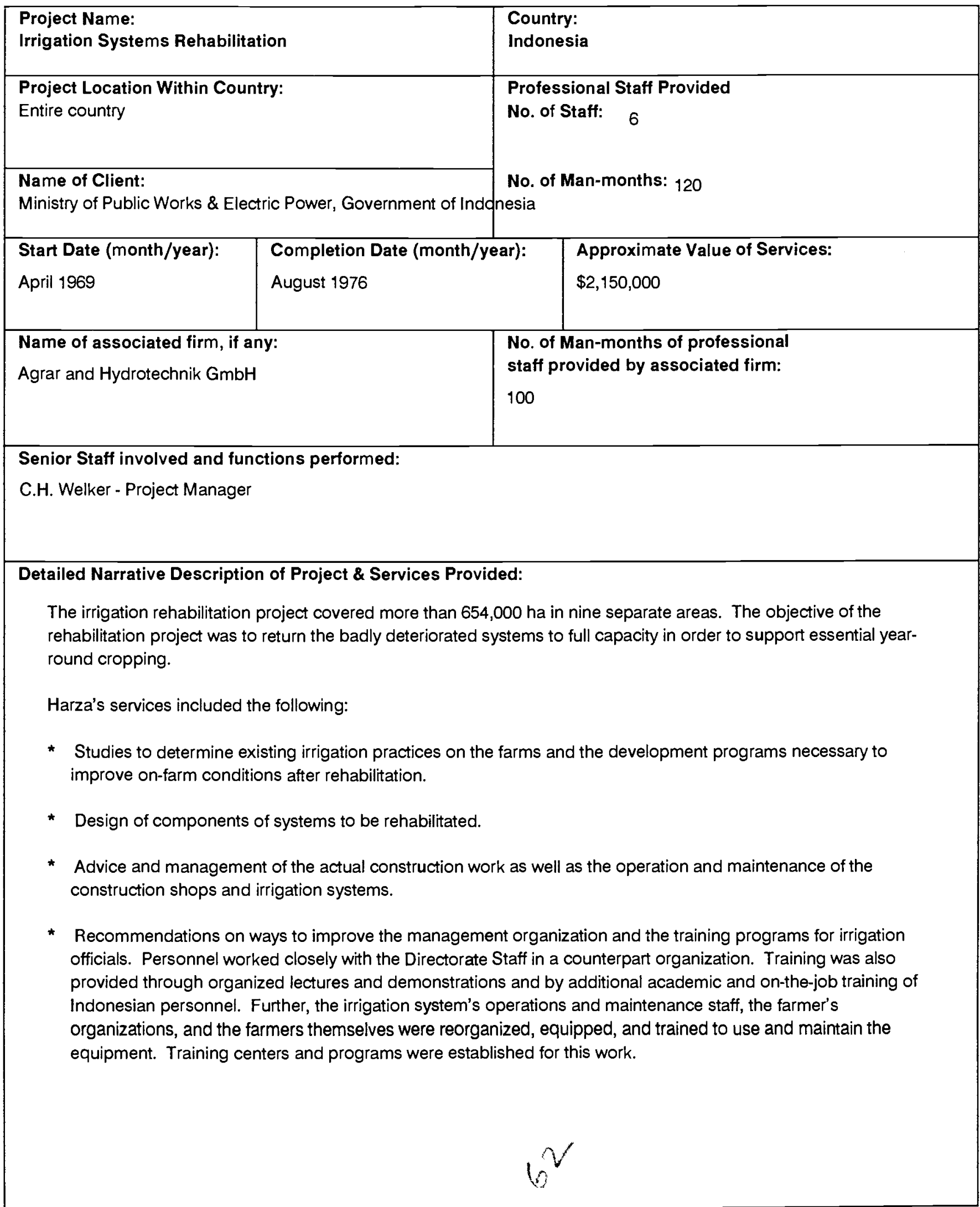




\section{CONSULTING ASSIGNMENTS WHICH BEST ILLUSTRATE QUALIFICATIONS}

The following information should be provided for each reference project in the format indicated below:

\begin{tabular}{|c|c|c|}
\hline \multicolumn{2}{|c|}{$\begin{array}{l}\text { Project Name: } \\
\text { Small Scale Irrigation Project }\end{array}$} & $\begin{array}{l}\text { Country: } \\
\text { Bangladesh }\end{array}$ \\
\hline \multicolumn{2}{|c|}{$\begin{array}{l}\text { Project Location Within Country: } \\
\text { Entire country }\end{array}$} & \multirow{2}{*}{$\begin{array}{l}\text { Professional Staff Provided } \\
\text { No. of Staff: } \\
\text { No. of Man-months: } 49\end{array}$} \\
\hline \multicolumn{2}{|c|}{$\begin{array}{l}\text { Name of Client: } \\
\text { Bangladesh Water Development Board }\end{array}$} & \\
\hline $\begin{array}{l}\text { Start Date (month/year): } \\
\text { April } 1981\end{array}$ & $\begin{array}{l}\text { Completion Date (month/year): } \\
\text { October } 1981\end{array}$ & $\begin{array}{l}\text { Approximate Value of Services: } \\
\$ 370,000\end{array}$ \\
\hline \multicolumn{2}{|c|}{$\begin{array}{l}\text { Name of associated firm, if any: } \\
\text { None }\end{array}$} & $\begin{array}{l}\text { No. of Man-months of professional } \\
\text { staff provided by associated firm: } \\
\text { None }\end{array}$ \\
\hline \multicolumn{3}{|c|}{$\begin{array}{l}\text { Senior Staff involved and functions performed: } \\
\text { R.C. Rudberg - Project Manager }\end{array}$} \\
\hline \multicolumn{3}{|c|}{$\begin{array}{l}\text { Harza was retained by the Asian Development Bank to assist the Bangladesh Water Development Board in } \\
\text { preparing an Irrigation Sector Project for a possible loan from the Bank. The Technical Assistance project included } \\
\text { three components: }\end{array}$} \\
\hline \multicolumn{3}{|c|}{ 1.Identify and rank 30 small scale irrigation, drainage, and flood control projects for possible implementation; } \\
\hline \multicolumn{3}{|c|}{$\begin{array}{l}\text { 3.Formulate the sector project, including guidelines, procedures, and criteria to be used in implementing the } \\
\text { Sector Project. }\end{array}$} \\
\hline \multicolumn{3}{|c|}{$\begin{array}{l}\text { Harza provided a full range of services including engineering, agronomy, and economics. Much of the work was } \\
\text { related to the feasibility study of the six selected subprojects for which preliminary design and cost estimates were } \\
\text { prepared and project economic and financial assessments were made. Modes of development for which feasibility } \\
\text { studies were made included private well development. }\end{array}$} \\
\hline
\end{tabular}




\section{CONSULTING ASSIGNMENTS WHICH BEST ILLUSTRATE QUALIFICATIONS}

The following information should be provided for each reference project in the format indicated below:

\begin{tabular}{|c|c|c|}
\hline \multicolumn{2}{|c|}{$\begin{array}{l}\text { Project Name: } \\
\text { Irrigation System Rehabilitation }\end{array}$} & $\begin{array}{l}\text { Country: } \\
\text { Bangladesh }\end{array}$ \\
\hline \multicolumn{2}{|c|}{ Project Location Within Country: } & $\begin{array}{l}\text { Professional Staff Provided } \\
\text { No. of Staff: } \quad 4\end{array}$ \\
\hline $\begin{array}{l}\text { Name of Client: } \\
\text { Engineering and Planning }\end{array}$ & ultants, Ltd. & No. of Man-months: 15 \\
\hline $\begin{array}{l}\text { Start Date (month/year): } \\
1986\end{array}$ & $\begin{array}{l}\text { Completion Date (month/year } \\
1987\end{array}$ & $\begin{array}{l}\text { Approximate Value of Services: } \\
\text { US } \$ 250,000\end{array}$ \\
\hline \multicolumn{2}{|c|}{$\begin{array}{l}\text { Name of associated firm, if any: } \\
\text { None }\end{array}$} & $\begin{array}{l}\text { No. of Man-months of professional } \\
\text { staff provided by associated firm: }\end{array}$ \\
\hline
\end{tabular}

Senior Staff involved and functions performed:

R.C. Rudberg - Project Manager

Detailed Narrative Description of Project \& Services Provided:

The Bangladesh Water Development Board (BWDB) has constructed about 300 water projects which are completed and in operation. These projects were built for many purposes, including flood control, drainage, irrigation, town protection and erosion control. Most of the projects are of small or medium scale.

A large number of the BWDB completed projects have lost some or all of their original effectiveness due to lack of timely maintenance, resulting principally from inadequate funding for that purpose in the annual Revenue Budget of the Government of Bangladesh.

This United Nations Development Programme (UNDP) financed study had the following objectives: based on a survey of BWDB infrastructure works, defined the need for structure rehabilitation including the types of structure in need of rehabilitation, approximate costs for the works, and improvement in project function that will result; assessed the capacity and needs of the BWDB for implementing a rehabilitation programme as well as maintaining the works in the improved condition following implementation; prepared an inventory of assets and liabilities of each scheme including surplus lands, equipment and construction materials and identified the surplus resources which may be utilized otherwise; prepared guidelines for transferring the completed schemes of BWDB to Upazila parishads for operation and maintenance or otherwise; furnished the collected informations in a prescribed proforma for use in computer; prepared the Terms of Reference for a feasibility study. For the selected schemes.

As subcontractor to EPC Harza assisted in planning system rehabilitation and improvement for existing irrigation and drainage systems and in preparing tender documents. An important part of the work was developing operational and management procedure to keep the systems running smoothly and effectively long into the future.

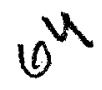




\section{CONSULTING ASSIGNMENTS WHICH BEST ILLUSTRATE QUALIFICATIONS}

The following information should be provided for each reference project in the format indicated below:

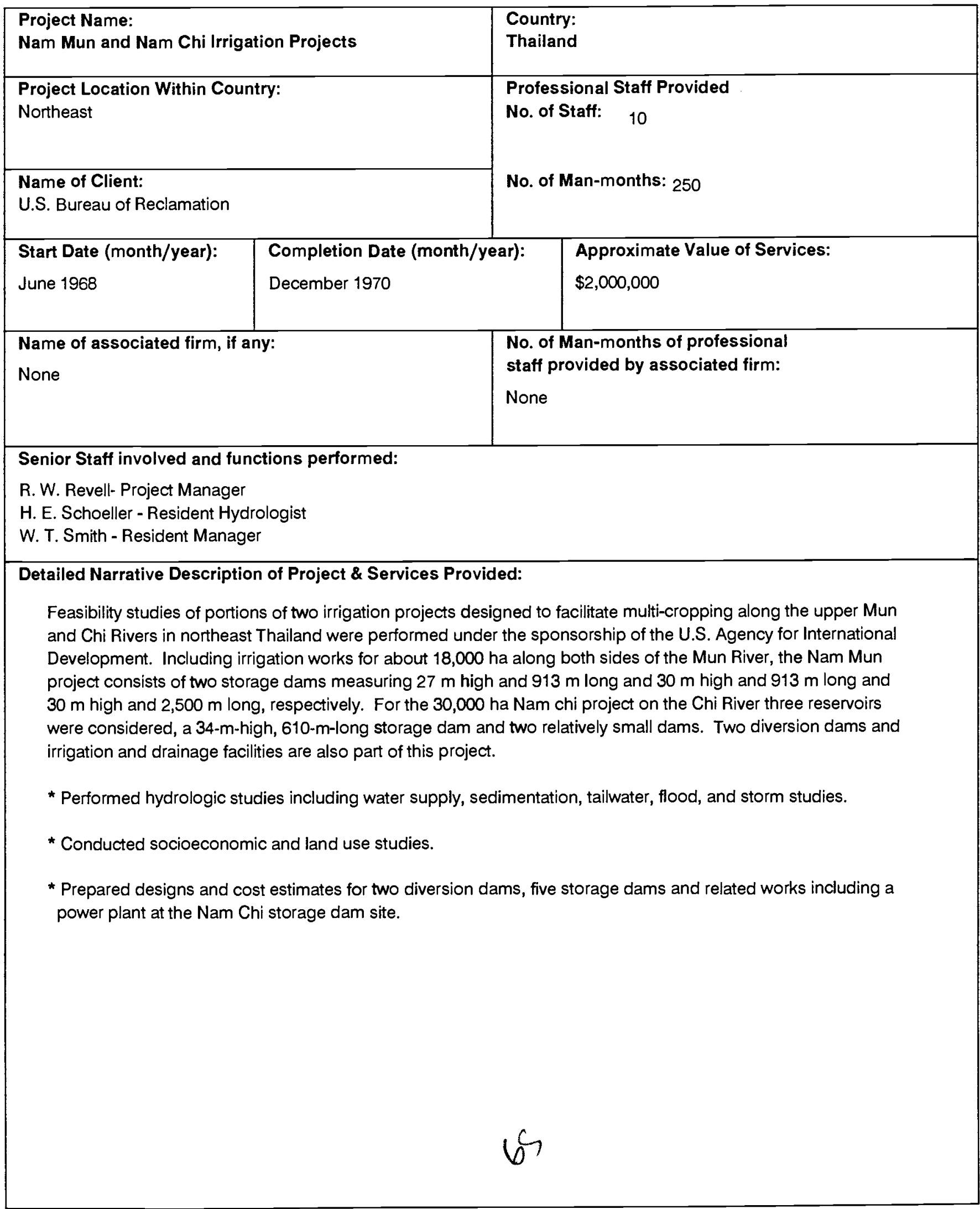




\section{Project}

EGYPT

Main System

Management

Provincial

Cities Project

Aswan Old Dam

Urban Distribution
Systems

National Rural Electrification Plan

Egypt Master Plan

El Nasr Canal Rehabilitation

Irrigation Management

Project

IRAN

Karadj Dam

Karun Dam

Nader Shah Dam

Utility Management

Services

Karun EHV Transmission System

Gotvand Irrigation Project

Beheban Irrigation Project
Client

Description

Services

Ministry of Public Work and Water Resources

USAID

The High and Aswan Dams Authority

Egyptian Electricity Authority

Rural Electrification Authority

World Bank

Ministry of Irrigation

Ministry of Irrigation

Tehran Water Board

Ministry of Water and Power

Ministry of Water and Power

Ministry of Energy

Ministry of Water and Power

Ministry of Energy

Khuzestan Water and Power Authority
Control of the Nile water to increase agricultural production.

Construction management services for water and wastewater facilities.

Perform stability analysis of the dam.

P,D

Electrical rehabilitation work for four cities.

$\mathrm{P}, \mathrm{D}, \mathrm{C}, \mathrm{S}$

Rehabilitation and expansion of electrical distribution systems in rural areas.

Advisory services for Egypt Water Resources Planning.

Rehabilitation of main irrigation canal.

$P, D, C, S$

Develop capabilities in Ministry of Irrigation to prepare planning and feasibility studies.

$P, D, C, S$

P

M

Double-curvature, thin-arch dam for water supply, irrigation and power.

$P, D, C, S$

Multi-purpose double curvature, multicentered concrete arch dam for flood control, irrigation and power.

Earth and rockfill dam for irrigation and power.

P,D,C

Provide utility management and operating services.

400-kV transmission system including $850 \mathrm{~km}$ of transmission lines.

Diversion dam and canal.

$P, D, C$

Irrigation and drainage of 15,000 ha including diversion weir, two pumping stations, canals, drains and related structures. 
Project

Client

Description

Services

IRAQ

Derbendi Khan Dam

Development Board of Iraq

Hydrologic Survey of Iraq

Development Board of Iraq

Eski Mosal Project

Government of Iraq

Jalaula - Derbendi Kahn

Highway

Bekhme Dam

Directorate General of Irrigation

Development Board of Iraq

Kaiseba Irrigation Project

FAO - Rome

Derbendi Khan Gates

\section{JORDAN}

Al Wehdah Dam

Red Sea - Dead Sea

Hydropower Development

Jordan Valley Irrigation

Project, Stage II

Jordan Valley Marketing

Study

Raising of King Talal Dam Jordan Valley Authority

East Ghor Canal Project Jordan Valley Authority
Jordan Valley Authority

Jordan Valley Authority

Jordan Valley Commission

State Organization for Dams

Jordan Valley Authority

Irrigation modernization and expansion project including earth dam, and conversion 11,000 ha from gravity to sprinkler irrigation.

Marketing study to determine future demand for agricultural products of the Jordan Valley

Raising of King Talal dam by $9.5 \mathrm{~m}$ to replace storage lost by sedimentation

Diversion, irrigation and drainage systems including $\mathbf{4 3 . 5}$ miles of concrete lined canal and development of 11,000 ha.
$P, D, C, S$

$\mathrm{P}$

$\mathrm{P}$

$P, D$

$P, D$

$P, C$

D

$P, D$

$P$

$P, D, C$

P

$\mathrm{P}, \mathrm{D}, \mathrm{C}, \mathrm{S}$

$P, D, S$

LEGEND: $\quad \mathrm{P}=$ Planning $\quad \mathrm{D}=$ Design $\quad \mathrm{C}=$ Contract Document $\mathrm{S}=$ Services During Construction $M=$ Management Services $T=$ Technical Services 


\section{HARZA REPRESENTATIVE PROJECTS IN THE MIDDLE EAST (CONT'D)}

\section{Project}

\section{OMAN}

Burami Flood Control Airport

Nejd Soil and Groundwater Survey

Earth Science

Consultancy

\section{SAUDI ARABIA}

Makkah University Wastewater Treatment and

Storm Management

Improved Agricultural Development (Qatif-Area)

Date Palm Tissue Culture Laboratory

Water Supply Reservoir

New Jeddah International Airport

Underground Distribution Review

Agricultural Drainage Projects

Al Mazarat Farm Development Survey

\section{SUDAN}

Energy Planning and Management Project

Kassala Water Supply

\section{Client}

Description

Regional Development Committee

Ministry of Agriculture and Fisheries

United Nations Development Program

Skidmore, Owings and Merrill

Ministry of Agriculture and Water

Ministry of Agriculture and Water

Dar Al Handasah Consultants

Skidmore, Owings and Merrill

James P. Driscoll Company

Ministry of Agriculture and Water

Prince Waleed

USAID and Sudan National Electricity Corporation

United Nations Development for the Kassala province.
Develop plan to protect the town of Bu-<smiles>[Pb]</smilesrami from flooding. Under separate assignment, evaluated recharge potential of flood-detention reservoir.

Preliminary soil and groundwater survey.

Seismicity studies report on seismicity T and tectonic structures.

Review of the master plan design concept of the wastewater treatment plant and stormwater management.

Planning and design of irrigation and drainage and support facilities $(6,200$ ha).

Prepare plans, designs and contract documents for a genetics engineering lab and greenhouse to process palm tissue cultures annually.

Consulting engineering

Wastewater treatment and solid waste disposal plant.

Review drainage and specifications for distribution of power from $3-26 \mathrm{MW}$ gas turbines to a new village near Jeddah

Drainage of the Ghuwayba and West of Dammans Areas

Determine groundwater and soils suitability for farm development.

P Consulting engineering and utility management services.

Provide water supply needs assessment $\mathbf{p}$
900727

069\FS\EXP-ARE\TABLES HRPITME 


\section{CONSULTING ASSIGNMENTS WHICH BEST ILLUSTRATE QUALIFICATIONS}

The following information should be provided for each reference project in the format indicated below:

\begin{tabular}{|c|c|c|c|}
\hline \multicolumn{2}{|l|}{$\begin{array}{l}\text { Project Name: } \\
\text { Gotvand Irrigation Project }\end{array}$} & \multicolumn{2}{|c|}{$\begin{array}{l}\text { Country: } \\
\text { Iran }\end{array}$} \\
\hline \multicolumn{2}{|c|}{$\begin{array}{l}\text { Project Location Within Country: } \\
\text { Khunzestan Province }\end{array}$} & \multirow{2}{*}{\multicolumn{2}{|c|}{$\begin{array}{l}\text { Professional Staff Provided } \\
\text { No. of Staft: } 60 \\
\text { No. of Man-months: } 900\end{array}$}} \\
\hline \multicolumn{2}{|c|}{$\begin{array}{l}\text { Name of Client: } \\
\text { Khunzestan Water and Power Authority }\end{array}$} & & \\
\hline $\begin{array}{l}\text { Start Date (month/year): } \\
1965\end{array}$ & $\begin{array}{l}\text { Compl } \\
1978\end{array}$ & & $\begin{array}{l}\text { Approximate Value of Services: } \\
\$ 11,000,000\end{array}$ \\
\hline \multicolumn{2}{|c|}{$\begin{array}{l}\text { Name of associated firm, if any: } \\
\text { F. \& H.R. Farman - Farmaian }\end{array}$} & \multicolumn{2}{|c|}{$\begin{array}{l}\text { No. of Man-months of professional } \\
\text { staff provided by associated firm: } \\
200\end{array}$} \\
\hline \multicolumn{4}{|c|}{$\begin{array}{l}\text { Senior Staff involved and functions performed: } \\
\text { J.D. Earles - Project Manager, Chicago Office } \\
\text { J.C. Van der Wiel - Resident Manager in Tehran for Design and Tendering } \\
\text { G.B. Thompson - Resident Engineering During Construction }\end{array}$} \\
\hline \multicolumn{4}{|c|}{$\begin{array}{l}\text { Detailed Narrative Description of Project \& Services Provided: } \\
\text { Harza in association with the Iranian consulting firm Farman-Fa }\end{array}$} \\
\hline
\end{tabular}




\section{CONSULTING ASSIGNMENTS WHICH BEST ILLUSTRATE QUALIFICATIONS}

The following information should be provided for each reference project in the format indicated below:

\begin{tabular}{|c|c|c|c|}
\hline \multicolumn{2}{|c|}{$\begin{array}{l}\text { Project Name: } \\
\text { Jordan Valley Irrigation Project - Stage II }\end{array}$} & \multicolumn{2}{|c|}{$\begin{array}{l}\text { Country: } \\
\text { Jordan }\end{array}$} \\
\hline \multicolumn{2}{|c|}{$\begin{array}{l}\text { Project Location Within Country: } \\
\text { East Jordan Valley }\end{array}$} & \multirow{2}{*}{\multicolumn{2}{|c|}{$\begin{array}{l}\text { Professional Staff Provided } \\
\text { No. of Staff: } \\
\text { No. of Man-months: } 1,200\end{array}$}} \\
\hline \multicolumn{2}{|l|}{$\begin{array}{l}\text { Name of Client: } \\
\text { Jordan Valley Authority }\end{array}$} & & \\
\hline $\begin{array}{l}\text { Start Date (month/year): } \\
\text { April } 1976\end{array}$ & $\begin{array}{l}\text { Completio } \\
\text { December }\end{array}$ & ar): & $\begin{array}{l}\text { Approximate Value of Services: } \\
\$ 18,000,000\end{array}$ \\
\hline \multicolumn{2}{|c|}{$\begin{array}{l}\text { Name of associated firm, if any: } \\
\text { Dar Al-Handasah (DAR) }\end{array}$} & \multicolumn{2}{|c|}{$\begin{array}{l}\text { No. of Man-months of professional } \\
\text { staff provided by associated firm: } \\
\text { Not available }\end{array}$} \\
\hline \multicolumn{4}{|c|}{$\begin{array}{l}\text { Senior Staff involved and functions performed: } \\
\text { M.P. Saunders - Project Manager (feasibility) } \\
\text { J.C. Van der Weil - Project Manager (design) }\end{array}$} \\
\hline \multicolumn{4}{|c|}{ Detailed Narrative Description of Project \& Services Provided: } \\
\hline \multicolumn{4}{|c|}{$\begin{array}{l}\text { This project will control and regulate the } \\
\text { efficiency irrigation methods and agricul } \\
\text { Principal elements of the project area: }\end{array}$} \\
\hline \multicolumn{4}{|c|}{$\begin{array}{l}\text { * Al Wehdah (formerly Maqarin) Dam and Reservoir. The reservoir will store water for irrigation, municipal, and } \\
\text { industrial uses, and for } 22.5 \mathrm{MW} \text { of power generation. }\end{array}$} \\
\hline \multicolumn{4}{|c|}{ * Diversion for Wadi Raqqad into the Al Wehdah reservoir. } \\
\hline \multicolumn{4}{|c|}{$\begin{array}{l}\text { * Adasiye diversion facilities, approximately } 37 \mathrm{~km} \text { (23 miles) downstream from the dam). } \\
\text { * East Ghor Main Canal on the left bank of the Jordan River. The existing canal will be rehabilitated and }\end{array}$} \\
\hline \multicolumn{4}{|c|}{$\begin{array}{l}\text { * Installation of a pressure distribution irrigation system of approximately } 12,000 \text { ha }(29,600) \text { of presently surface- } \\
\text { irrigated land. This includes } 22 \text { pump stations. }\end{array}$} \\
\hline \multicolumn{4}{|c|}{ * Single circuit transmission lines 31 km long. } \\
\hline $\begin{array}{l}\text { * Subsurface drainage } \\
\text { investigations, desig }\end{array}$ & $\begin{array}{l}\text { salinity con } \\
\text { struction, } 0\end{array}$ & enar & $\begin{array}{l}\text { e in planning soil and water table } \\
\text { of surface and subsurface drainage systems. }\end{array}$ \\
\hline
\end{tabular}




\section{CONSULTING ASSIGNMENTS WHICH BEST ILLUSTRATE QUALIFICATIONS}

The following information should be provided for each reference project in the format indicated below:

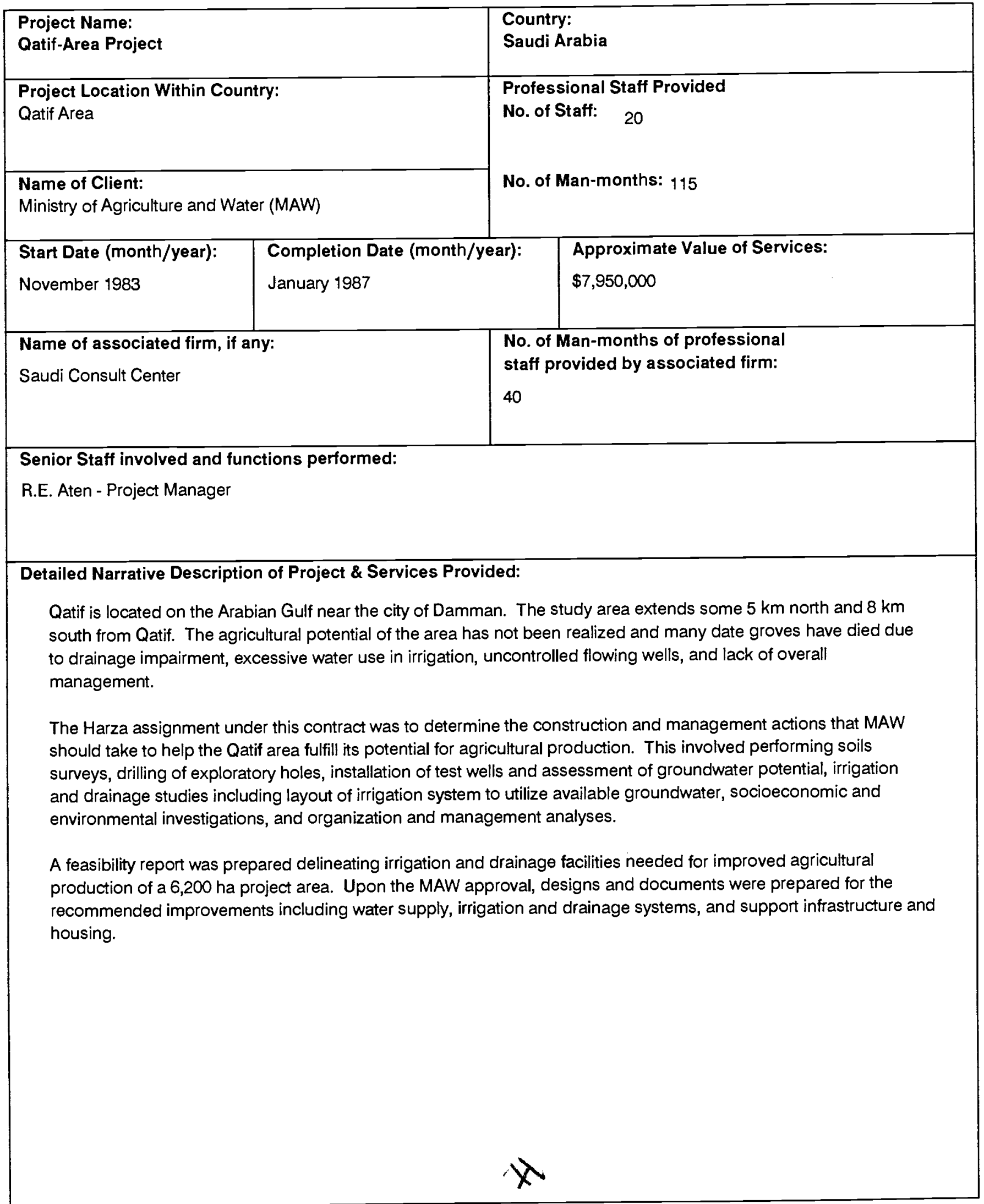




\section{CONSULTING ASSIGNMENTS WHICH BEST ILLUSTRATE QUALIFICATIONS}

The following information should be provided for each reference project in the format indicated below:

\begin{tabular}{|c|c|c|}
\hline \multicolumn{2}{|c|}{$\begin{array}{l}\text { Project Name: } \\
\text { Ghuwayba Agricultural Drainage Project }\end{array}$} & $\begin{array}{l}\text { Country: } \\
\text { Saudi Arabia }\end{array}$ \\
\hline \multicolumn{2}{|c|}{$\begin{array}{l}\text { Project Location Within Country: } \\
\text { Ghuwayba }\end{array}$} & \multirow{2}{*}{$\begin{array}{l}\text { Professional Staff Provided } \\
\text { No. of Staff: } 25 \\
\text { No. of Man-months: } 85\end{array}$} \\
\hline $\begin{array}{l}\text { Name of Client: } \\
\text { Ministry of Agriculture \& Water }\end{array}$ & & \\
\hline $\begin{array}{l}\text { Start Date (month/year): } \\
\text { May } 1982\end{array}$ & $\begin{array}{l}\text { Completion Date (month/year } \\
\text { October } 1985\end{array}$ & $\begin{array}{l}\text { Approximate Value of Services: } \\
\$ 1,826,000\end{array}$ \\
\hline \multicolumn{2}{|c|}{$\begin{array}{l}\text { Name of associated firm, if any: } \\
\text { Saudi Consult Center }\end{array}$} & $\begin{array}{l}\text { No. of Man-months of professional } \\
\text { staff provided by associated firm: } \\
30\end{array}$ \\
\hline \multicolumn{3}{|c|}{ Senior Staff involved and functions performed: } \\
\hline $\begin{array}{l}\text { J.E. Priest - Project Director } \\
\text { R.E. Aten - Project Manager } \\
\text { D.B. Palmer - Project Enginee }\end{array}$ & $\begin{array}{l}\text { R.K. Bull - Soils Scientist } \\
\text { R.D. Sargon - Project Engineer }\end{array}$ & \\
\hline
\end{tabular}

\section{Detailed Narrative Description of Project \& Services Provided:}

Harza performed detailed soil and land classification studies, performed drainage studies, developed alternative plans for improving existing drainage systems, and studied several methods for disposal of the drainage water from a 76 square $\mathrm{km}$ study area.

Detailed drainage studies led to the recommendation of subsurface perforated plastic tube drains. The disposal alternatives studied included: 1) improving and using an existing drain and evaporation lake; 2) desert disposal; 3) green-belt development; 4) subkhah disposal; and 5) dune disposal.

Cadastral and route surveys were completed and project facilities were assigned, and technical specifications and construction drawings were prepared.

Following the Ministry's approval, the design report, tender documents and an engineer's estimate were completed. 


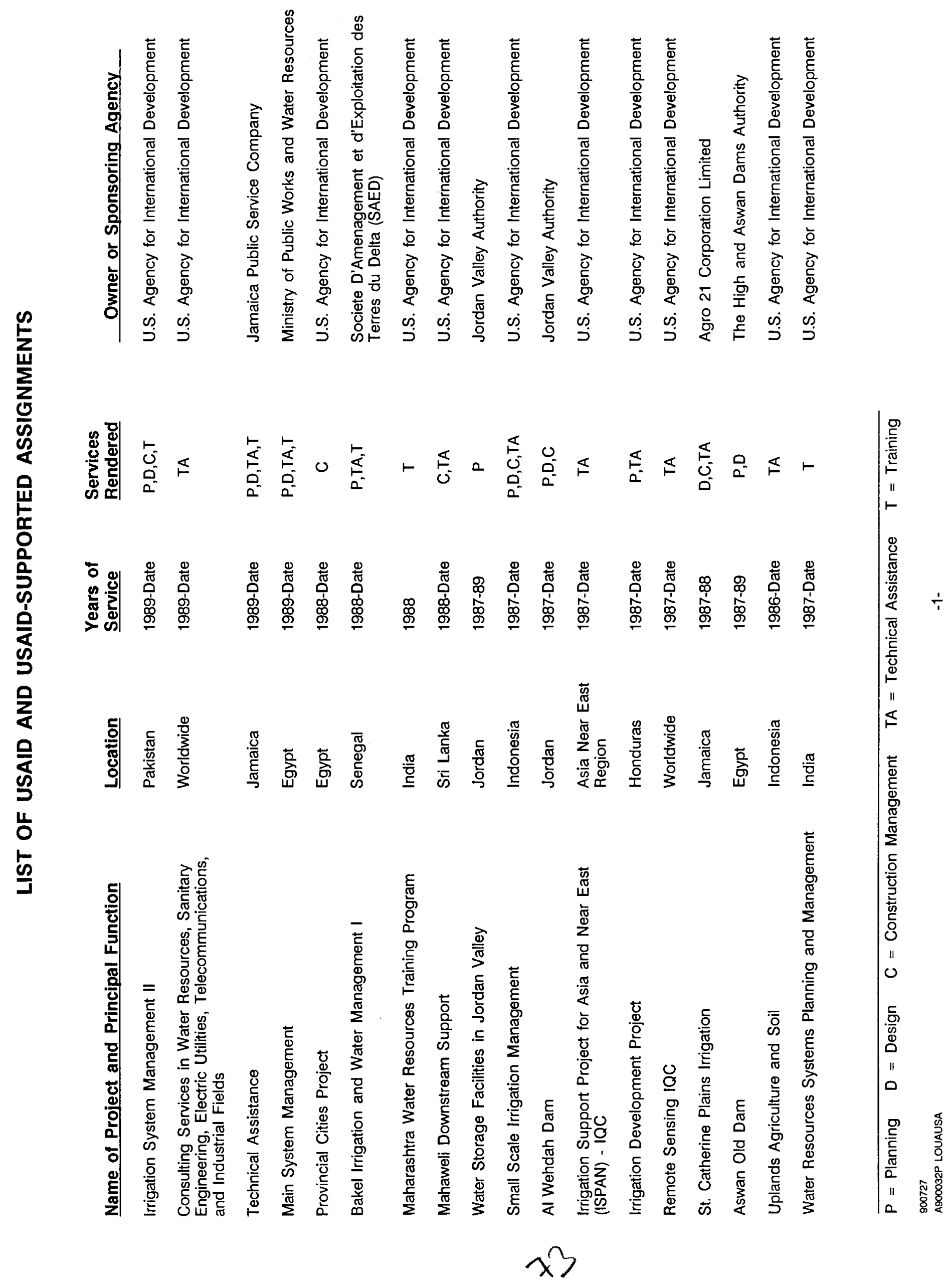




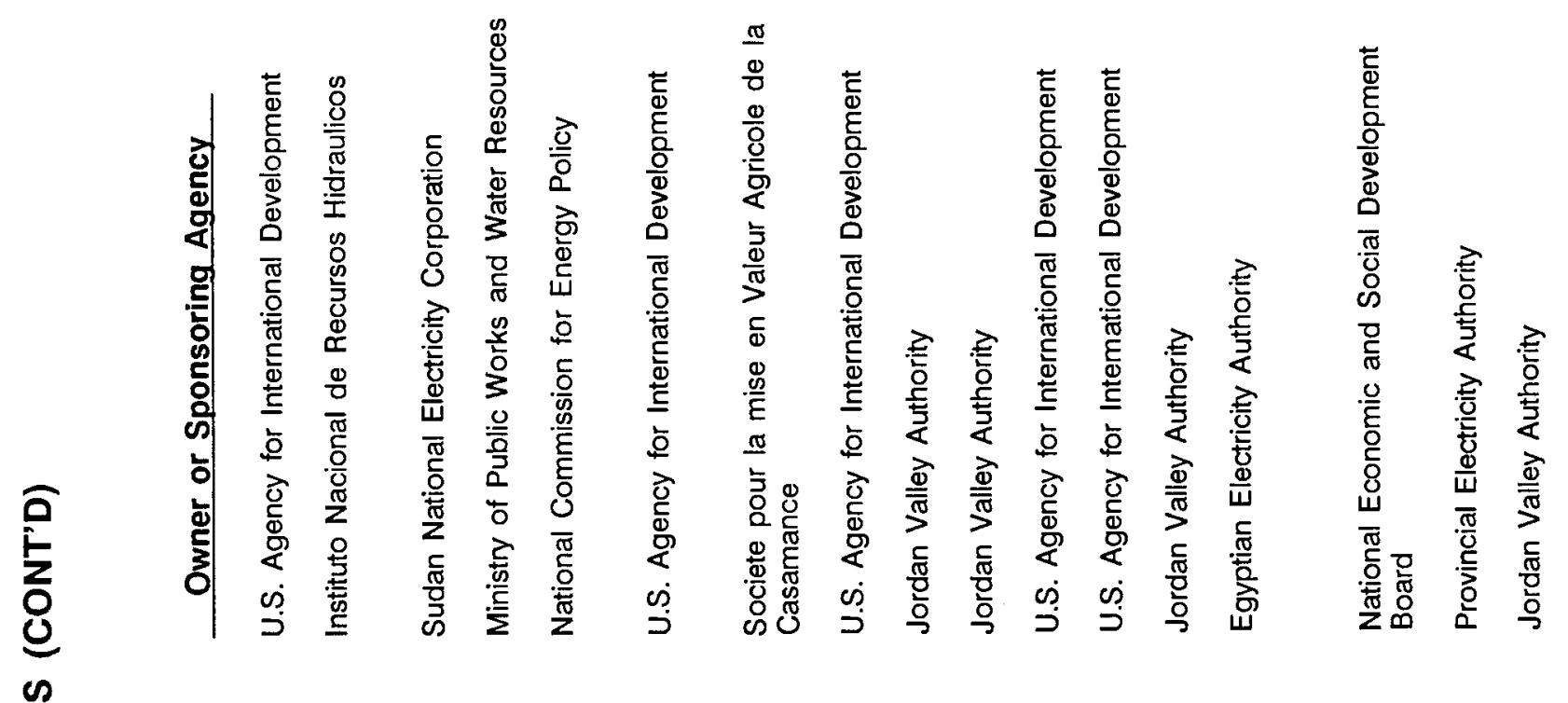

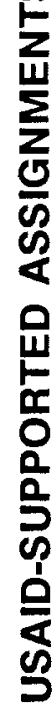

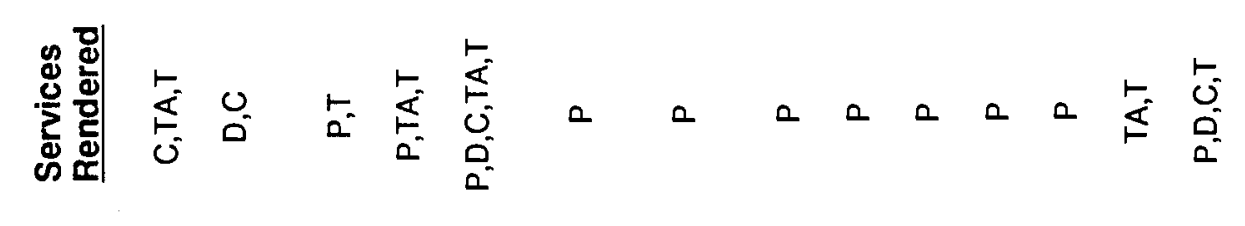

$-\frac{2}{2}$

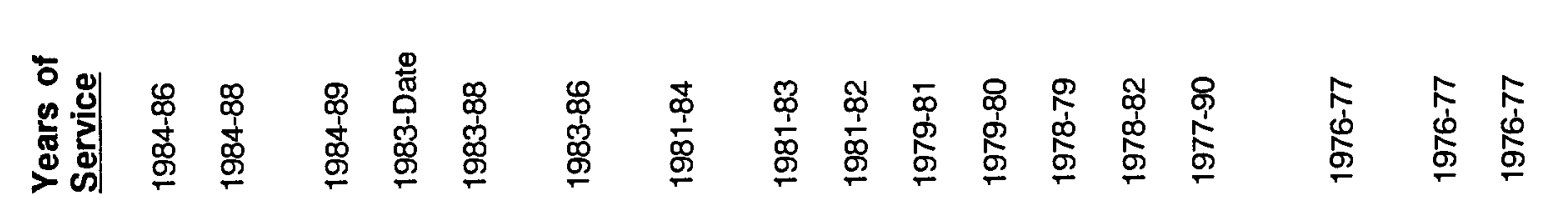

要

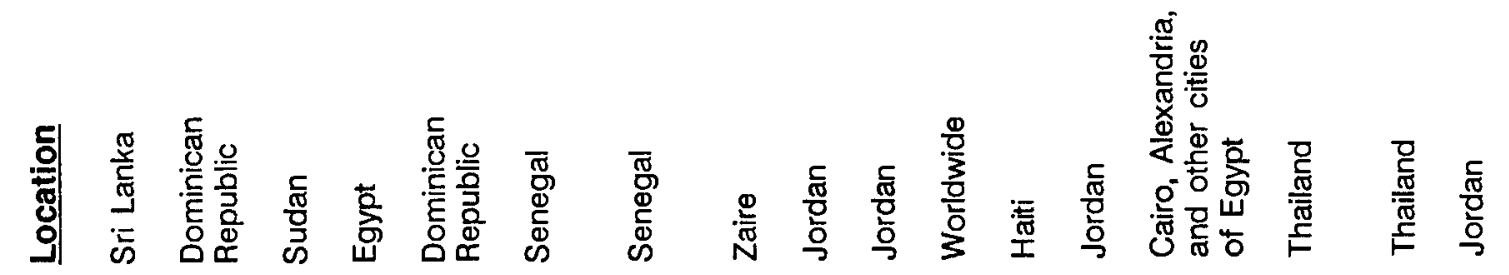

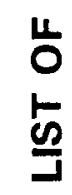

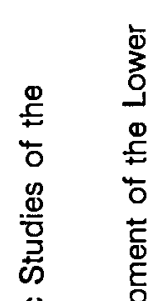

흘

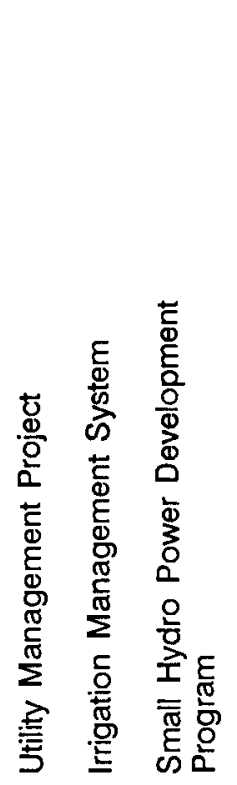

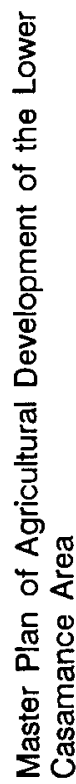

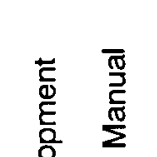

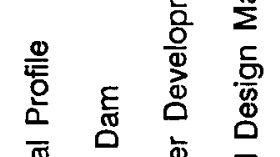

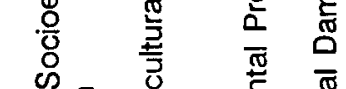

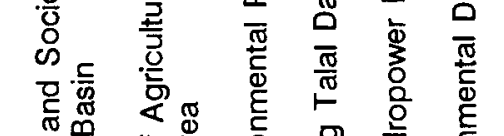

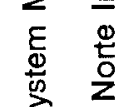

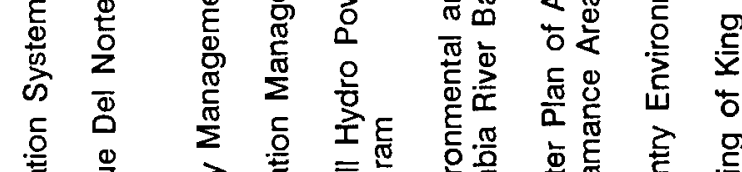

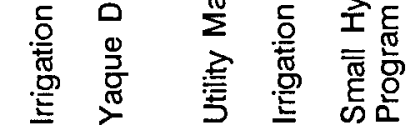




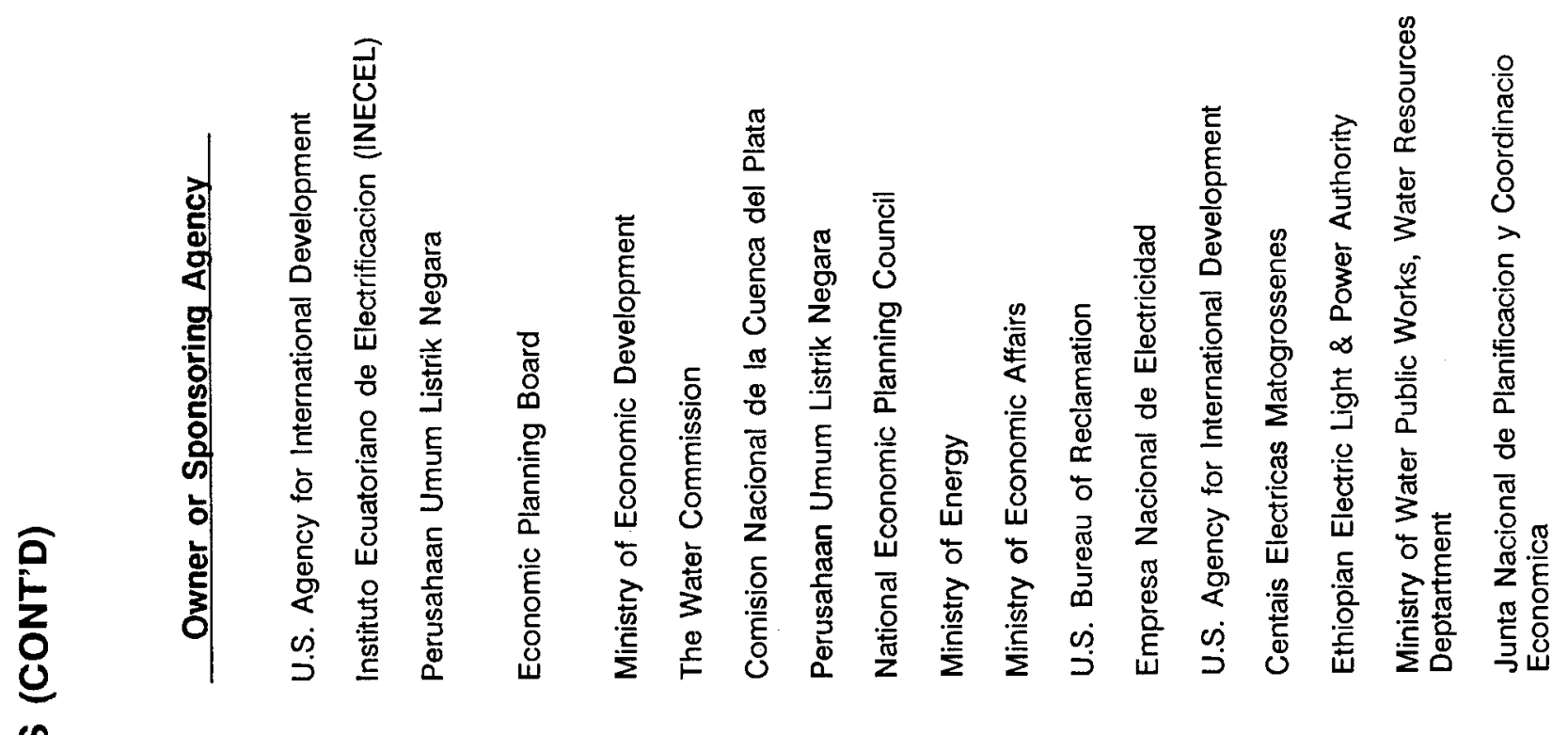

$\sum_{\substack{5 \\ 0}}^{\infty}$

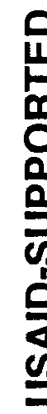

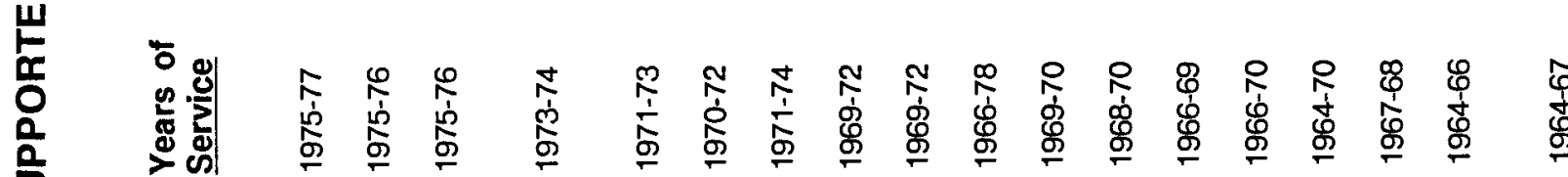

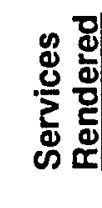

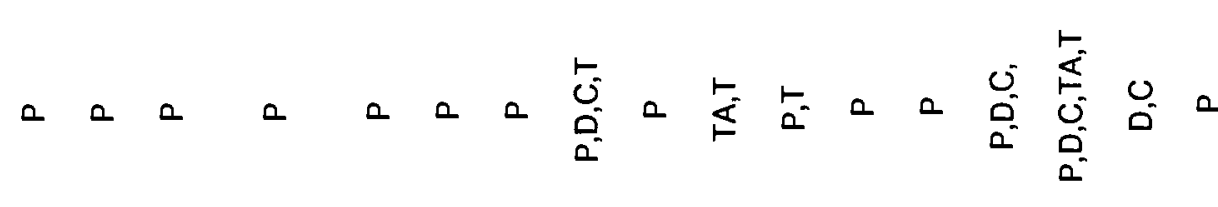

.

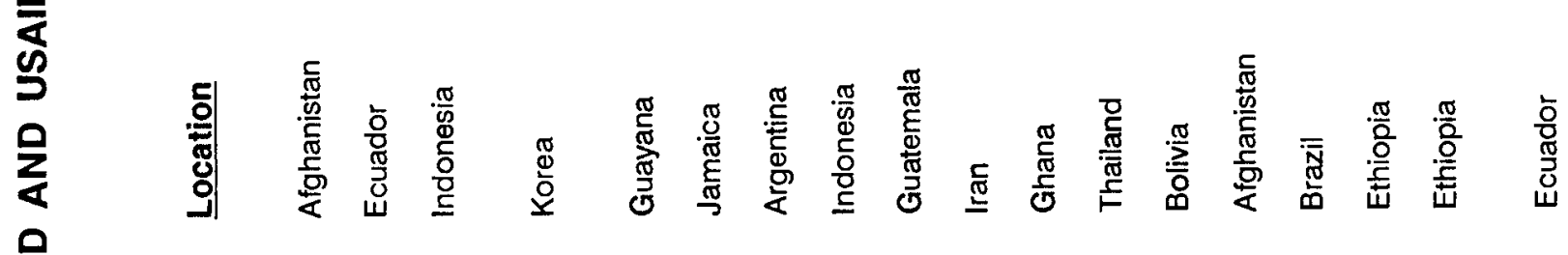

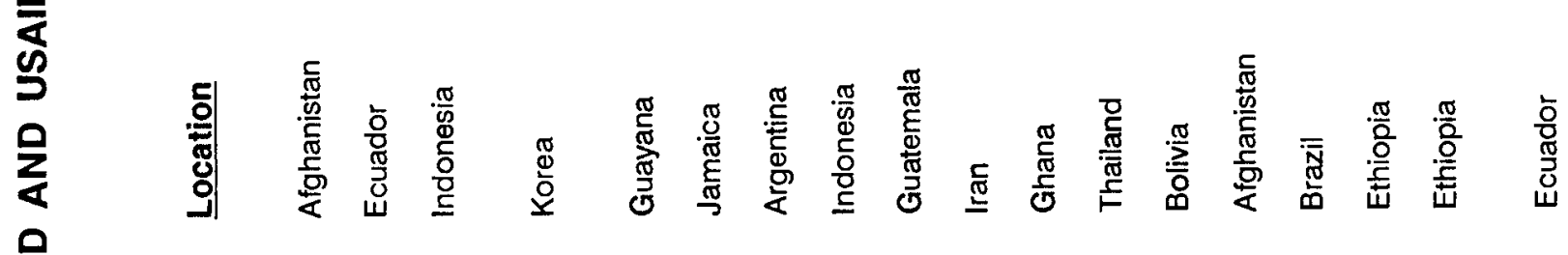

号

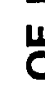

5

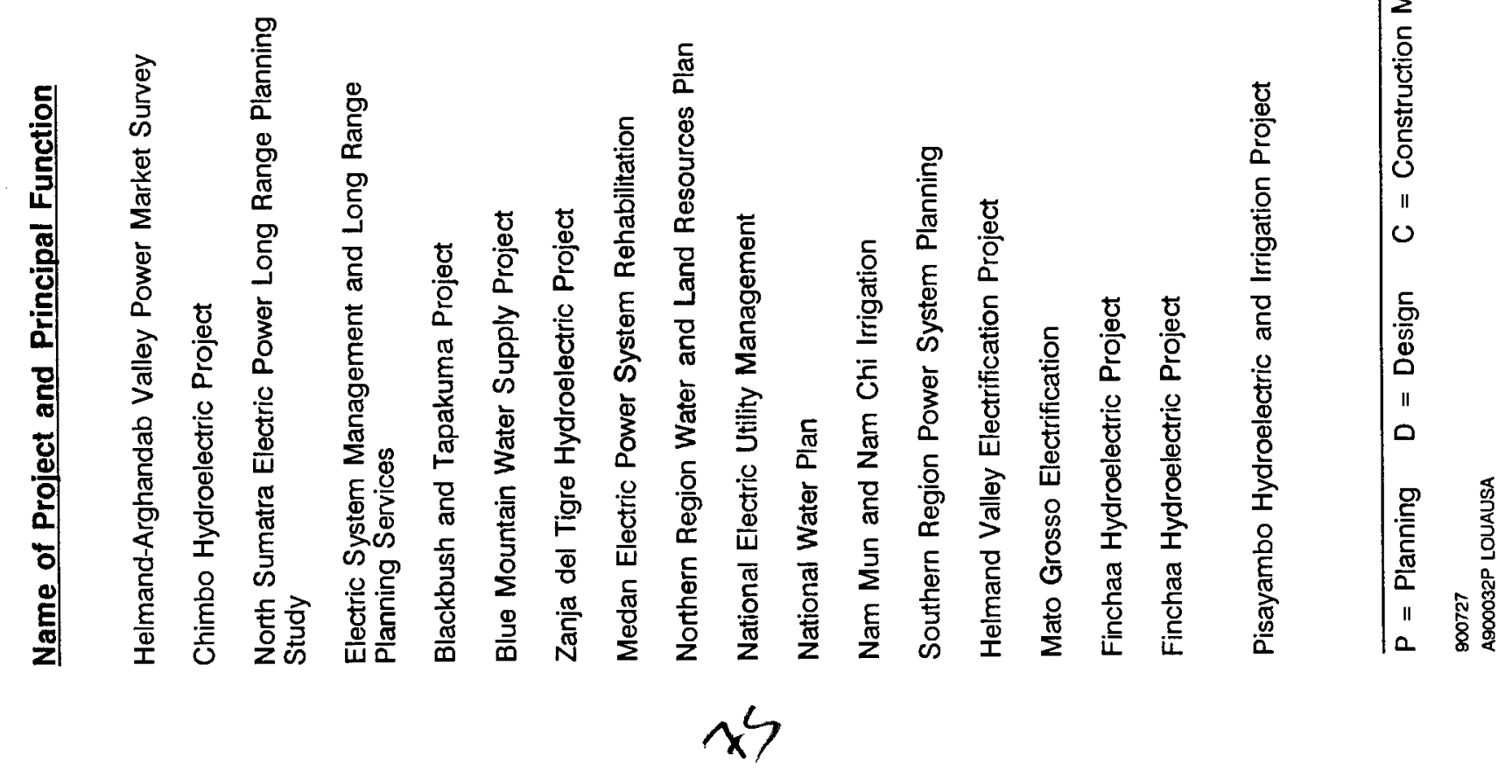




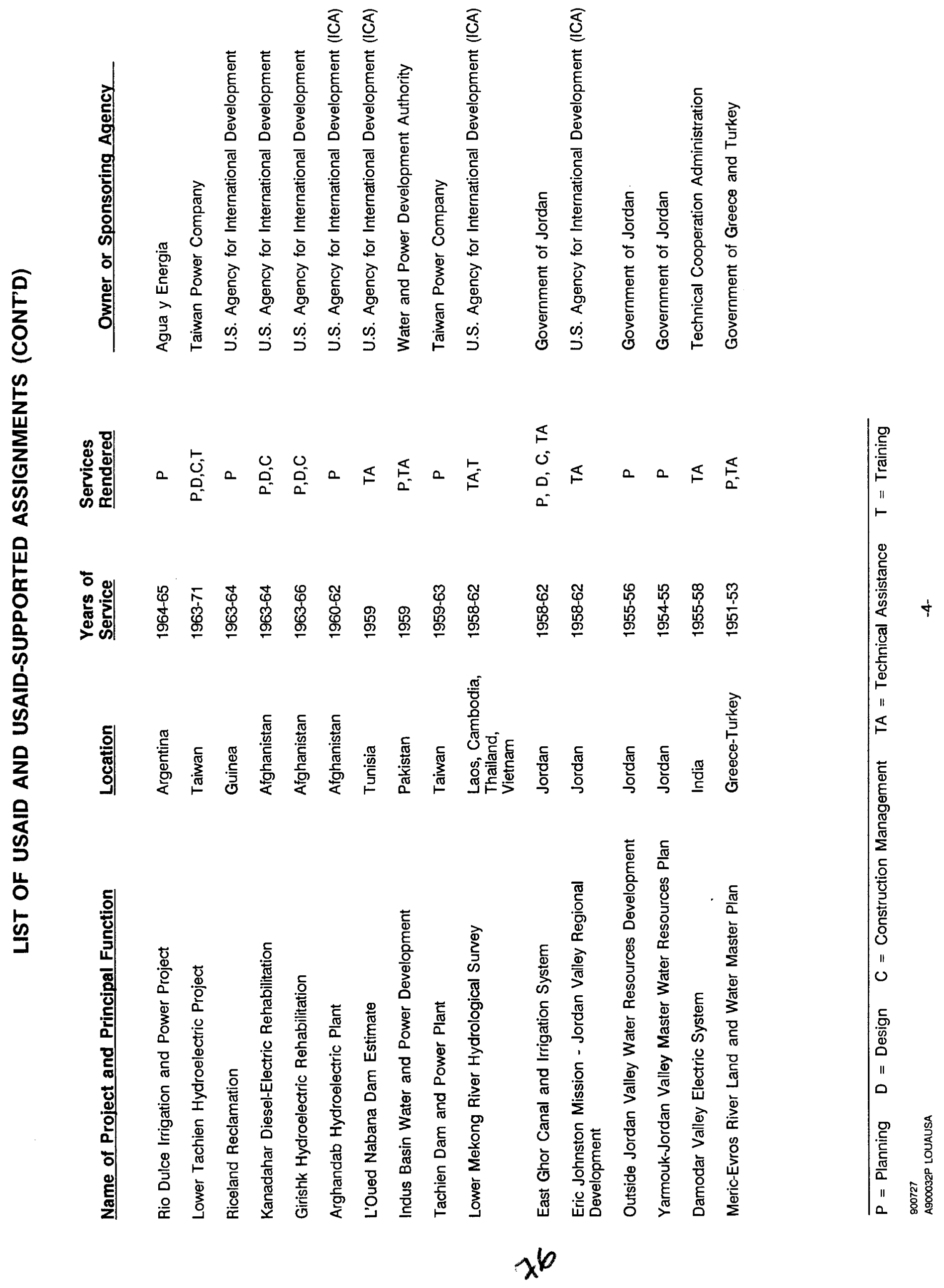




\section{EXPERIENCE IN TRAINING AND TECHNOLOGY TRANSFER}

\section{Introduction}

For the past 40 years, training has been an integral part of Harza's services on many projects worldwide. During this period, we have provided training, institutional development, and technology transfer services in more than 30 countries covering the areas of hydroelectric power, construction, agriculture, and water resources. We work closely with clients and host countries to establish well-defined systems and procedures, and customize our training services to best meet the needs of each client and project. Our approach of sharing our engineering expertise enhances and augments local practices and technological know-how.

An overview of Harza's training experience in the areas of power systems, construction and water resources development is presented in a table included at the end of this document.

During the course of our assignments we have been involved with:

- Organizational and operational analysis.

- Design and implementation of planning and management systems.

- Organization, administration, and training of site teams for technical oversight quality control, and contract administration for construction projects.

- Assisting with management procedures and operations.

- Developing information systems.

- Practical and operation training on-site or through seminars.

- Management training in local or U.S. academic institutions and government agencies.

- Specialized training in Harza offices and in other private or public organizations in the U.S. and other countries.

Specific examples of institutional development, technology transfer, and training activities carried out by Harza are discussed below. 


\section{Water Resources Systems Planning, India Government of India and USAID - 1987 to Date}

Water Resources Systems Planning and Management Program in India has, as its major objective, the development of the institutional capability for training in water resources planning and management. A Central Training Institute is being established in Pune, India. Emphasis in the program is being placed on computer-based systems analysis applied to detailed case studies of selected river basins in India. Trainees undertake either a three-month or nine-month program at the Pune Institute followed by a four week study tour to the United States. To date, Harza has organized two study tours, each for 25-30 trainees. As a part of the study tour, the trainees visit various water resources planning institutions in the U.S. including the U.S. Bureau of Reclamation, Tennessee Valley Authority and the California Department of Water Resources.

\section{Maharashtra Water Resources Training Program, India USAID - 1988}

Harza recently organized and implemented a 14 week study tour to the United States for 10 trainees from the Maharashtra Department of Irrigation. On that program, the trainees spent four weeks in the Harza Chicago office reviewing techniques for computer-aided water resource planning and reservoir operation. The trainees also visited the Salt River Irrigation Project in Arizona to study the operational aspects of a functioning irrigation system. That program also included a classroom component conducted at Utah State University.

\section{Irrigation System Management II, Pakistan USAID - 1989 to Date}

Harza is currently providing guidance and technical assistance to Pakistan's Provincial Irrigation Department (PIDs) in their responsibilities for construction, operation, and maintenance of the Indus Basin Irrigation and Drainage System, the largest contiguous irrigation system in the world. The ISM-II Project focuses on strengthening the physical tools and the organizational resources available to the PIDs to maintain the vast canal systems under their charge as well as increasing the benefits of irrigated agriculture. The project emphasizes evaluating the functions that must be performed in an effective program of canal maintenance, appraising how these functions may be carried out by the PIDs and providing technical assistance for institutionalizing these functions. 
Harza will assist in developing a training program covering the following subjects: preparation of estimates; preparation of design strategies; construction specifications and methods; construction planning; contract administration and quality control; operation and maintenance of canals. Training will a combination of U.S. based training, incountry courses, and on-the-job training.

\section{Guri Hydroelectric Project, Venezuela CVG-EDELCA - 1979-81}

CVG-EDELCA founded a Venezuelan agency, Ministry of Environment and Renewable Natural Resources (MARNR). Harza in association with the Venezuelan firm INELECTRA developed three comprehensive parametric cost estimating manuals for 1) preliminary level, 2) prefeasibility level hydroelectric project planning, and 3) watershed management. The manuals, containing an aggregate of approximately 560 pages in the Spanish language version alone, cover all aspects of development - dams, spillways, intakes, and water conduits, tunnels, outlet works, power stations, and equipment.

\section{Rural Electrification Authority Assistance, Egypt Egyptian REA - 1977-84}

Harza provided extensive support, guidance, and instruction to the Egyptian REA regarding the planning and construction management of a nationwide expansion of the country's electric distribution system. As part of this work, Harza developed schedule monitoring systems, including CPM networks, bar charts, and tabulations of available supplies and equipment. Harza engineers instructed REA personnel in the use of these systems during the construction phase.

\section{Lopez-Angostura Project, Dominican Republic Dominican Power Corporation (CDE) - 1983-88}

Harza provided resident engineering services for this hydroelectric project which includes a dam, spillway, diversion tunnel, water conductor (power) tunnel, and a subsurface pit-type powerhouse. To support the office engineering staff provided by the owner, Harza developed a computer program to compute and tabulate monthly pay estimates for the construction contractors. Harza provided an engineer to train CDE personnel in the use of this program. 


\section{Kajakai Service Area Power Market Study, Afghanistan Government of Republic of Afghanistan - 1976}

Harza provided resident personnel in southern Afghanistan who developed a system to survey the need for electric power in that area. Local power company personnel were instructed in the gathering of the required information, and in the tabulation of its results.

\section{Technical Services to Sudan National Electricity Corporation 1984-88}

Harza was retained by the Sudan National Electricity Corporation (NEC) to provide services to improve the reliability of NEC electricity service.

Harza provided assistance in:

- Management and operational systems and controls.

- Legislative and regulatory concern and the development of standards.

- Development, modification, and implementation of the purchase and stores system.

- Planning and budgeting procedures and techniques.

- Financial controls.

- Development of plans to balance electricity supply and demand in order to improve the efficiency of electricity use.

- Development of rates which reflect true systems costs.

- Installation, maintenance, use of the hardware and software facilities, and software development. 


\section{Urban Distribution Systems, Egypt Egyptian Electricity Authority and USAID - 1977-90}

In 1977, Harza was retained by the Egyptian Electricity Authority (EEA) and USAID to provide engineering services necessary for the planning, design and implementation of expansion and rehabilitation work needed to provide reliable and efficient electrical service to the cities of Cairo, Alexandria, Shibin El Kom and Beni Suef.

The transfer of U.S. technology was an important goal of this project. Harza provided distribution and substation engineering experts, a computer specialist, a warehouse specialist, and construction specialists.

\section{Electric Utility Management Project, Iran Ministry of Energy and USAID - 1976-78}

Starting in 1966, Harza embarked upon a five year program to provide electric utility management and operating services to the Ministry of Energy. Harza services included management, financial and accounting, planning, engineering, personnel and training, economics and tariffs and operations of eleven Regional Electric Companies plus the generation and transmission company (TAVANIR).

Iranian personnel were trained for key staff positions in the Ministry's operations. This training included: (1) on-the-job training of counterpart personnel by the Harza expatriate staff, and (2) training programs in the U.S.A. organized by Harza Chicago staff.

The Harza Tehran staff also outlined in detail the basic manpower training requirements of the Ministry and its affiliated companies and recommended means for training Iranian technicians and workers in specialized skills required for the operation of an electric utility system. The initial courses of instruction were directed principally to training transmission, distribution and substation staff. These were later expanded to include diesel and steam power generation and electronics.

A multi-million dollar Training Center was constructed to serve approximately three hundred trainees at one time.

Harza assisted the Ministry in establishing a formal training program of management development for the top executives of the Power Division of the Ministry and associated operating utilities. The program utilized United States university seminars, professional management development seminars, on-the-job training, utility visits, and manufacturing firm tours to develop, train and otherwise encourage Iranian utility personnel to learn and implement modern theories and practices of management in the Iranian Electric and Water Utility Systems. 
Participants in this Program were selected by the Ministry from the Power Division, the Auditing Company, the Purchasing Company, TAVANIR, the Regional Electric Companies, and the Tehran Regional Water Board. A comprehensive and detailed program was arranged for each Executive or Manager in accordance with training and development plans for the individual.

As a preparatory program for United States visits, the Public Utilities Report (P.U.R.) Guide home study course were used. It covered the nature of the electric utility business, its importance in the economy, the conditions under which it is conducted, and its fundamental objectives and responsibilities.

The P.U.R. courses, with monthly sessions held in Tehran, were a valuable adjunct to the Executive Management Training Program. The monthly sessions also provided a forum for discussions of the assigned lessons and a means to exchange views with respect to implementation of the subject matter. Guest speakers, experts in electric utility management and operations, gave presentations at the monthly seminars.

Both the Executive Management Training Program and the supplementary P.U.R. course were used to further the competence of the managers, engineers, supervisors, and administrators in the Power Division and associated operational companies in the Iran Electric Utility System and the Tehran Regional Water Board. Because of their value, the Ministry has been continuing the two programs each year.

The training program in the United States generally covered a period of eight to ten weeks.

Harza personnel played major roles in formulating and implementing the program through contacts with the various institutions, coordinatirig and managing the activities of the engineers receiving training, and in providing assistance in setting up curricula.

\section{Master Planning for National Water Resources Development Government of Ghana - 1969-70}

Harza personnel, under subcontract to Robert R. Nathan Associates, Inc. and aided by Ghanian counterparts, evaluated the groundwater and surface water potential of the country on national, regional, and watershed bases. A comprehensive plan for water resources development was formulated. It included a ten-year program of water supply development to meet full requirements through the year 2000, community water supply system layouts, investment and personnel requirements, scheduling and financing recommendations, and recommendations for data collection and analysis. 
River basin development potentials were determined for all basins within the country, and a program was developed for ongoing planning studies. The recommended national water resources management program included an assessment of existing institutions and operational, regulatory, supporting, coordinating, staffing, and training needs.

Harza provided a resident engineer and long-term specialists in hydrology, hydrogeology, and water resources planning. Each of the resident specialists worked with the counterpart staff and provided on-the-job training. One important aspect of the project was the preparation of a River Basin Planning manual. The counterpart staff received training on use of the manual during its preparation. Harza's principal planning engineer and principal hydrologist supplemented the team with short term visits. The principal hydrologist presented a seminar on basic hydrology. Together, the resident staff and counterpart staff prepared a formal five-year development report that satisfied the requirements for international financing.

\section{Flood Control and Related Multi-Purpose Development, Honduras Ministries of Public Works and Natural Resources - 1976-79}

Harza was retained by the Government of Honduras to perform a feasibility study of the Quimistan Valley and a study of the Sula Valley including a prefeasibility of the valley's agricultural potential, a soil survey, and a feasibility level study for flood control with final designs of the priority hydraulic works. Training of government counterpart engineers, agronomists, and economists from the Ministries of Public Works and Natural Resources was emphasized in all phases of the project work. Harza also equipped a soils laboratory and trained client personnel in the appropriate analytical techniques and practices.

Training of the Honduran engineers and technicians included planning, hydrology, project layout, evaluation, and design. Agronomists were trained in soil survey techniques, agricultural data collection, and field testing, such as infiltration and hydraulic conductivity tests. Economists were trained in project analysis and evaluation and in farm survey techniques.

\section{Indus Basin Development, Pakistan}

Water and Power Development Administration - 1976-80

Harza completed an assignment for the World Bank to assist and advise the Water and Power Development Administration (WAPDA) of Pakistan in preparing a master plan for irrigated agriculture in the 35 million acre Indus Basin integrated system. The plan called the "Revised Action Programme" includes recommendations for policy and institutional adjustments and a schedule, through 1990 of projects for the planning, preparation and implementation of programs and projects for irrigation rehabilitation and 
development, surface storage and related hydroelectric generation, drainage, saline soil reclamation, groundwater development, and flood protection.

Harza provided resident advisors in the areas of planning, economics, irrigation, water resource engineering, agronomy, soil science, agricultural surveys, system analysis, and environmental science.

The project activities were undertaken and completed by the Master Planning Division of WAPDA with professional advice and technical guidance from the Harza Advisors. Thus, technology transfer was accomplished to further develop capabilities within WAPDA and other Federal and Provincial agencies for the independent continuation of planning in these fields.

A formal training program also was organized and coordinated by Harza. Two in-country workshops, study tours in U.S.A. and other countries for three senior officials, and four scholarships for training in U.S.A. and other countries were arranged and administered by Harza. Month-long workshops for WAPDA and for personnel from other governmental agencies were conducted on the subjects of water resources planning and groundwater modeling. Scholarships were awarded in the subjects of system analysis, flood management, groundwater modeling, and agricultural economics.

\section{Irrigation Management System Project, Egypt Ministry of Irrigation - 1983 to Date}

Harza was retained by the Egyptian Ministry of Irrigation in 1983 to provide services necessary to increase the efficiency and effectiveness of the irrigation system.

Harza is providing long- and short-term technical assistance in counterpart relationships to the Egyptian professionals. The objective is to develop and strengthen the capacity of the newly established Project Preparation Unit.

In addition to the counterpart training, technical assistance also includes short courses for engineers and technicians in irrigation design and construction, administration and management, and construction management methods and quality control.

Formal training abroad is being provided to more than 50 Egyptian personnel to provide exposure to the most modern standards and engineering and management techniques.

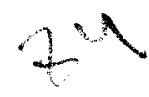




\section{Organization Strengthening, Bangladesh World Bank - 1980-83}

This project entailed the strengthening of the administrative, managerial, and implementation aspects of the development programs of the Bangladesh Water Development Board. Harza provided daily, on-the-job training by using counterpart relationships. Short courses, seminars, and workshops were developed to cover the topics and areas most emphasized in the work. These were designed to include specific and general lectures. Harza personnel assisted in the selection of candidates for advance training.

\section{Irrigation Systems Rehabilitation, Indonesia Directorate General of Water Resources Development - 1969-76}

Harza performed an eight-year program of technical assistance and guidance to the Directorate General of Water Resources Development for the rehabilitation of irrigation systems. These systems, totaling about 654,000 ha, had lost efficiency as a result of inadequate maintenance since World War II. The feasibility of rehabilitating four additional irrigation systems (primarily rice) serving an aggregate area of about 250,000 ha also was investigated.

Following completion of the feasibility reports, Harza specialists prepared a "Guidelines Manual" to provide the field staff with uniform criteria for the design of drainage systems, irrigation works, and desilting basins.

During the rehabilitation phase counterpart training was provided whereby two Indonesians served alongside their Harza counterparts in the following positions: resident manager, irrigation design engineer, construction plant engineer, agricultural economist, agronomist, operation and maintenance specialist, and field (irrigation construction) engineers.

Organized lectures, demonstrations and on-the-job training were part of the program. Visits to Japan, the Philippines and Taiwan were arranged for selected client personnel for observation and training.

Harza also prepared an Operations and Maintenance Manual for the system which incorporated the best of local experience and modern practice. 


\section{Small Hydro Power Development Program, Dominican Republic National Commission for Energy Policy - 1983-89}

In 1983 the National Commission for Energy Policy (COENER) in the Dominican Republic retained Harza to provide technical assistance services in the development of a nation-wide program comprising project identification, screening, planning, evaluation, design, contracting and construction phases for the development of small hydro power projects. The program included the construction of several plants with installed capacities generally in the range of $1,000 \mathrm{~kW}$.

Transfer of technology to Dominican personnel was one of the principal objectives of Harza's technical assistance. Harza provided a resident advisor for the overall planning, scheduling, coordination and supervision of the program, plus specialists on short-term assignments in the following categories: planning, environmental, soil mechanics and geology, hydro-mechanical and civil works, electro-mechanical, operation and maintenance, financial and rate scheduling, watershed conservation, and production use of energy.

Harza's specialists in the above areas worked in close cooperation with a counterpart group integrated by technical personnel from COENER and local agencies INDRHI and CDE. 


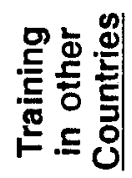

昜

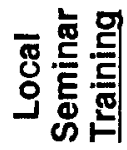

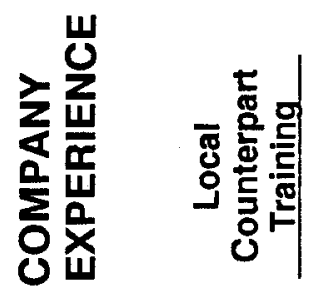

焉变

稳

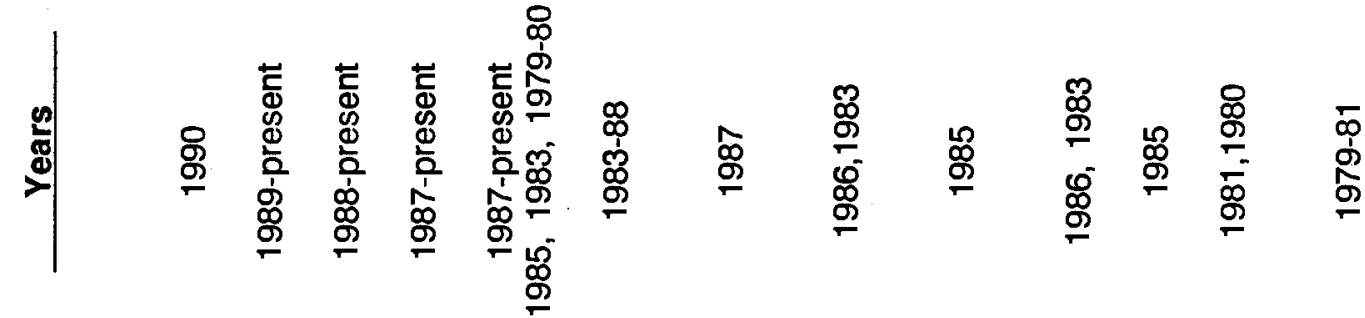

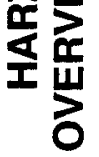

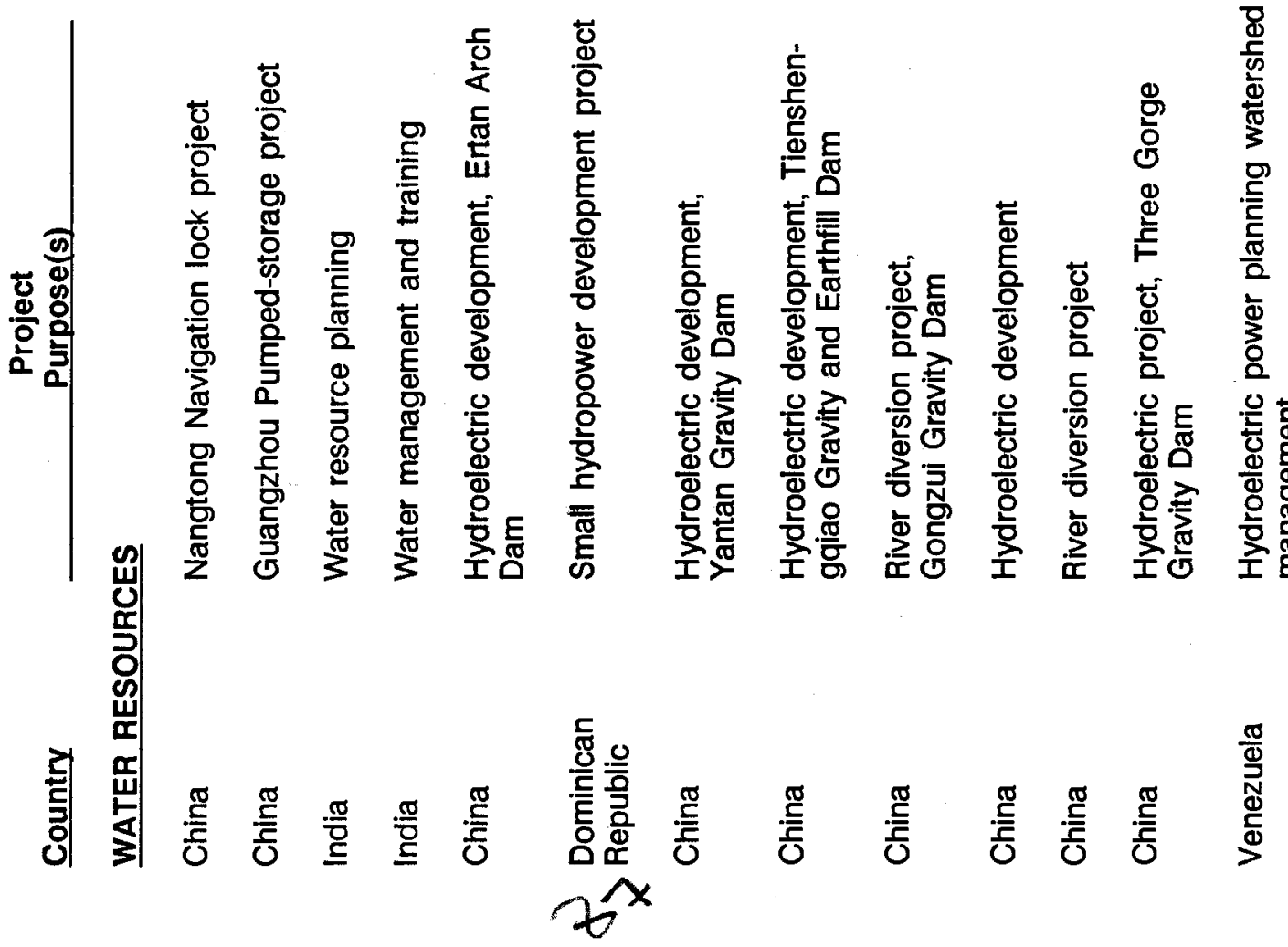


国

产: $=$

蛋

斑岂

|

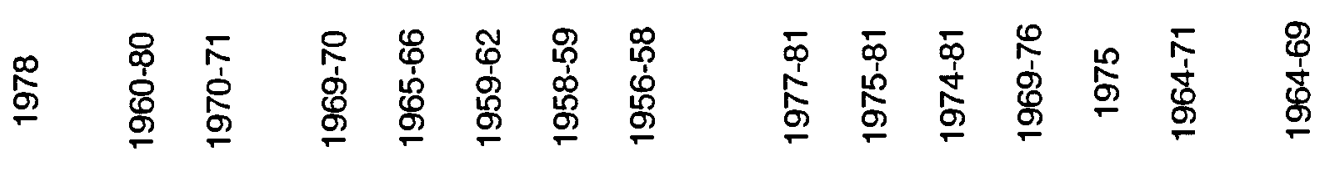

㸴崖

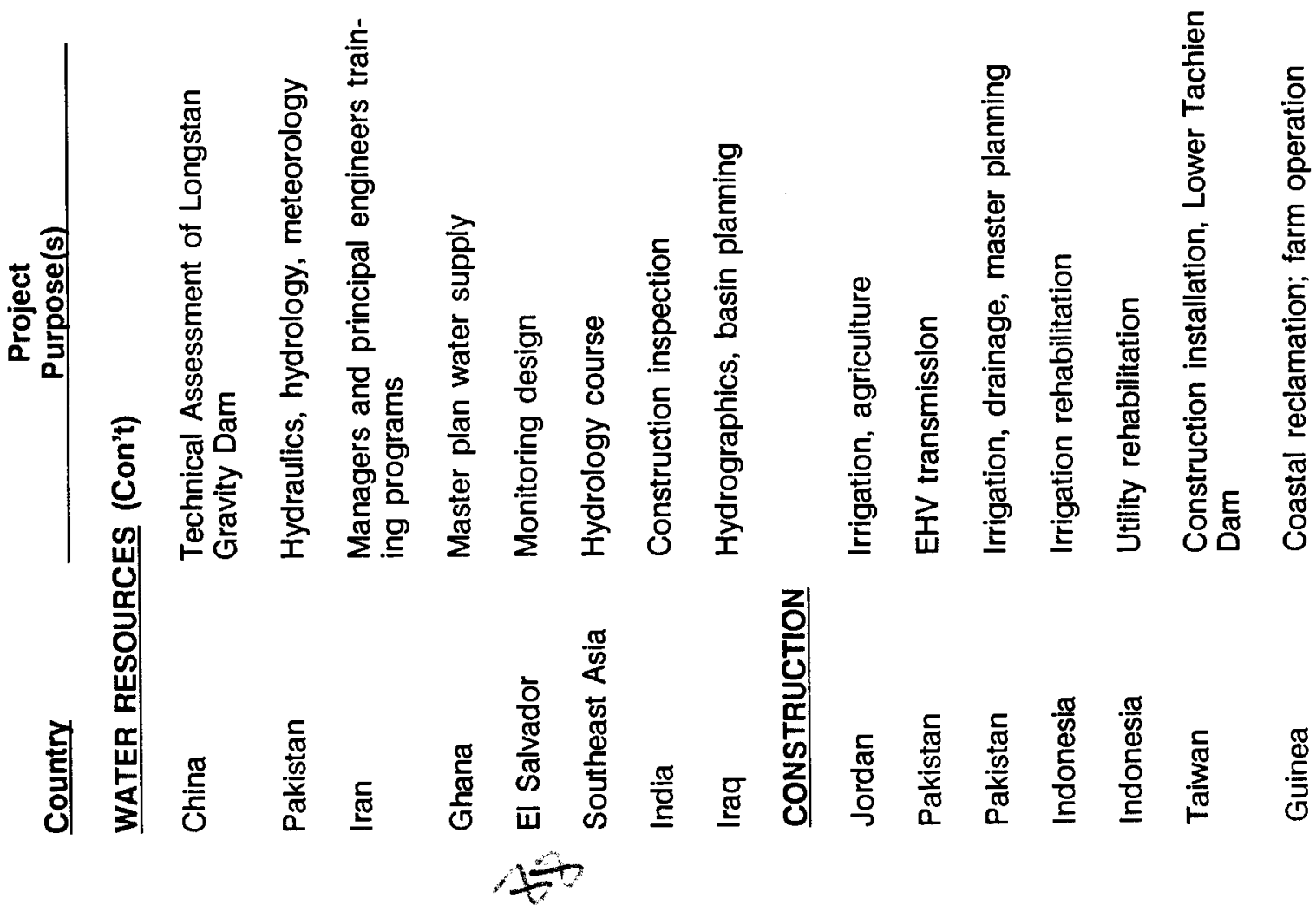




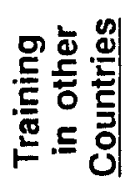

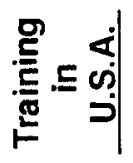

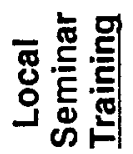

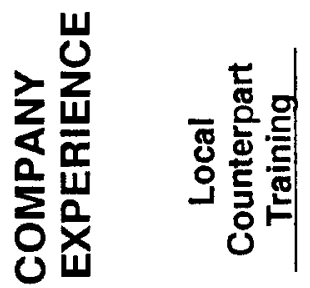

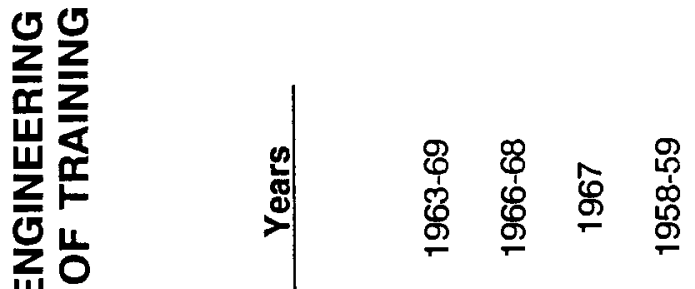

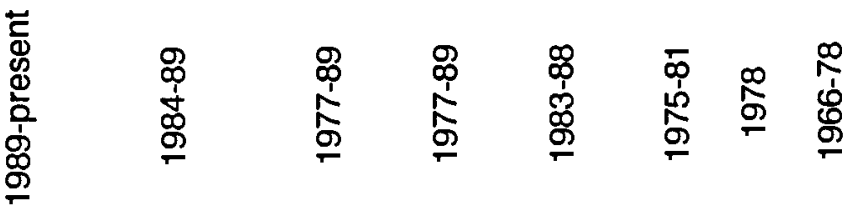

䍃罊

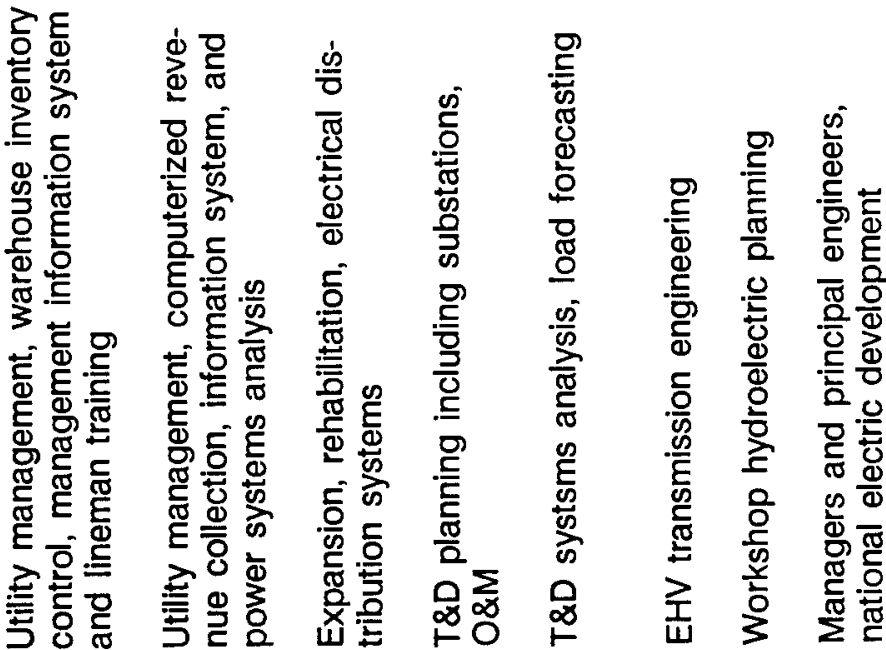

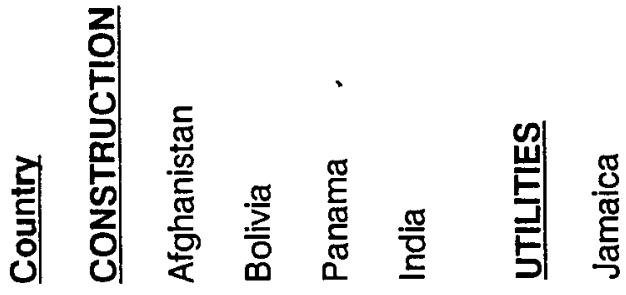

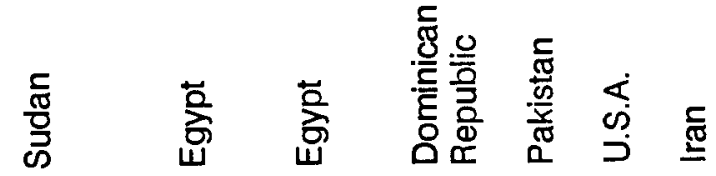




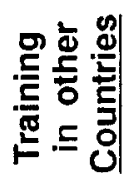

产

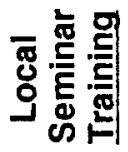

紊至

|

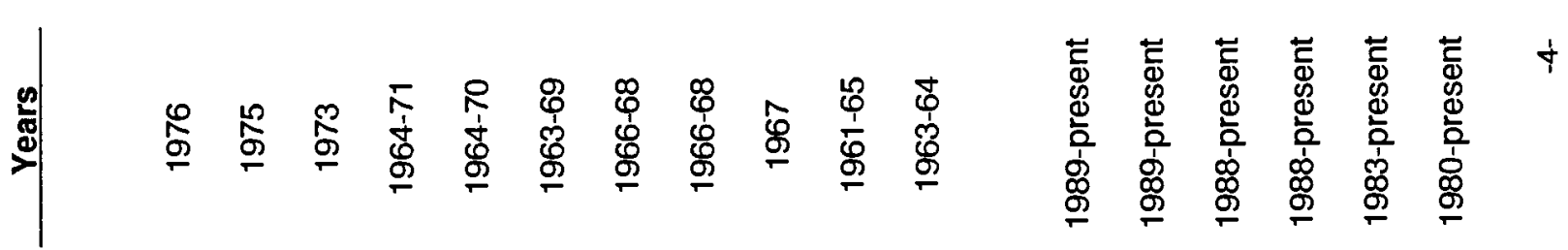

页䎡

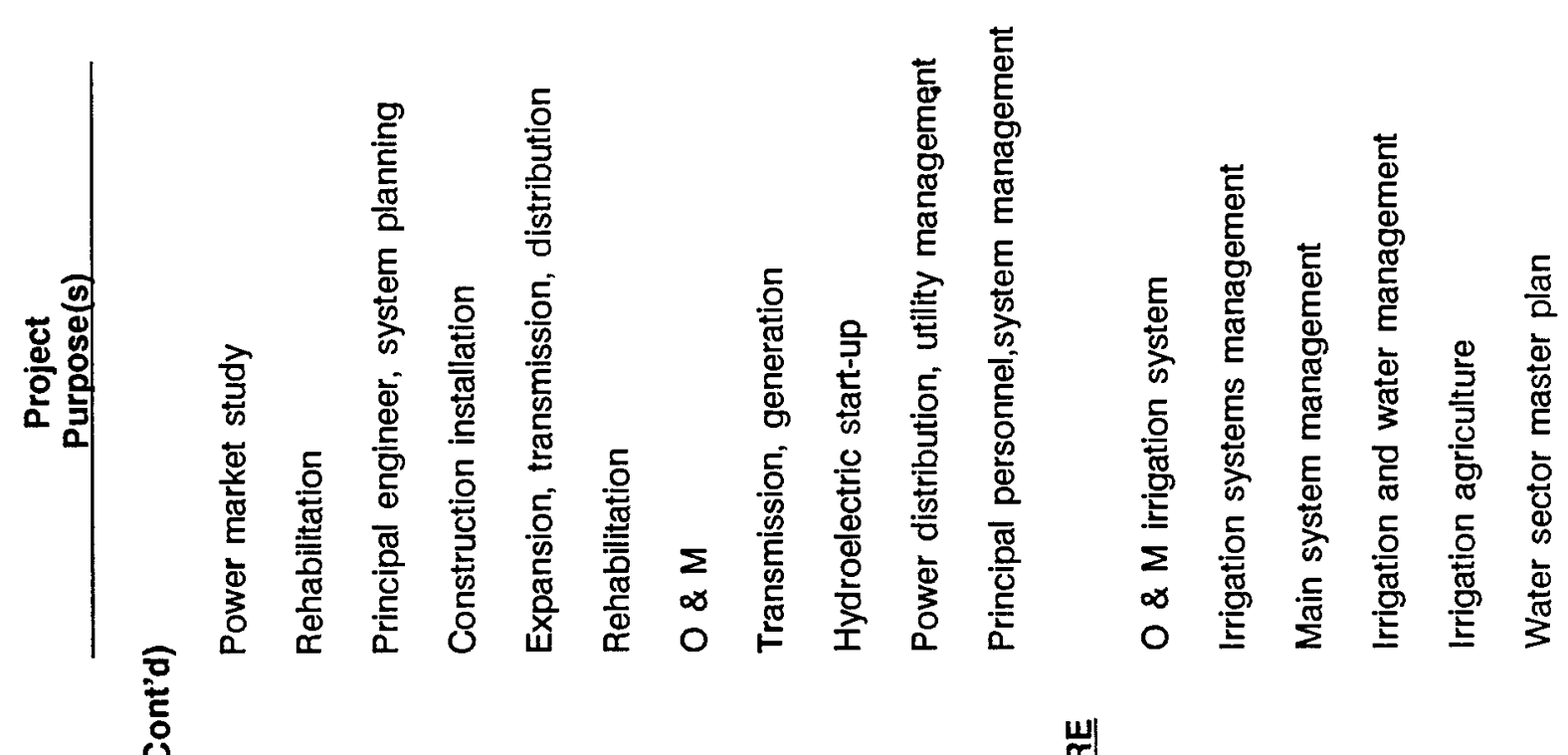

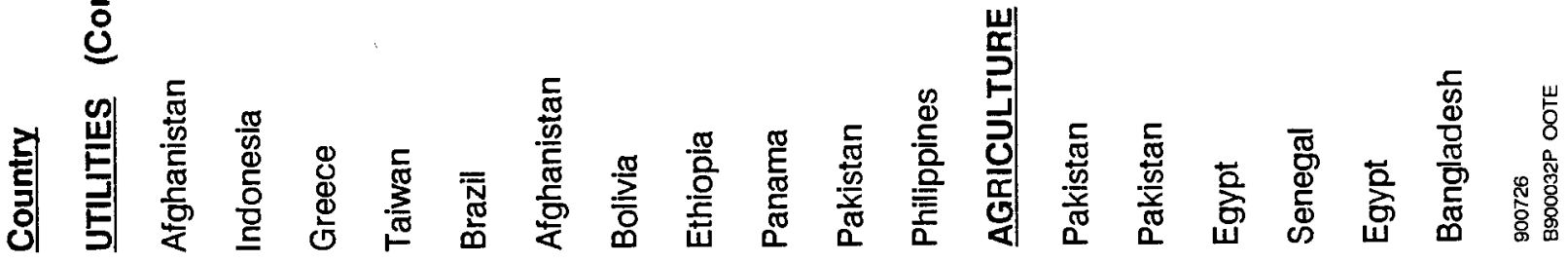




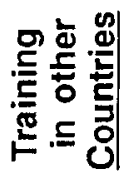

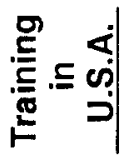

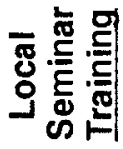

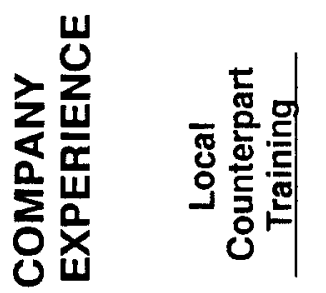

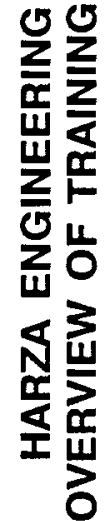

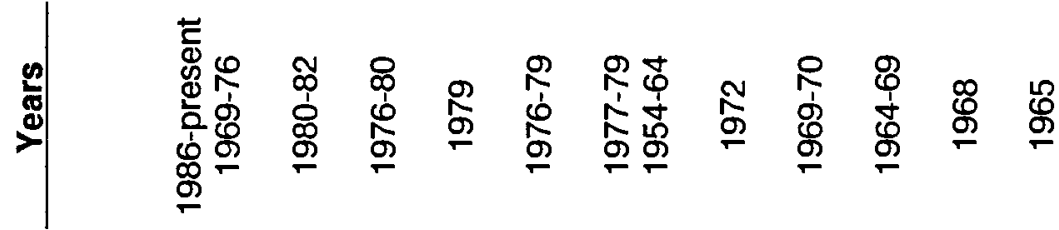

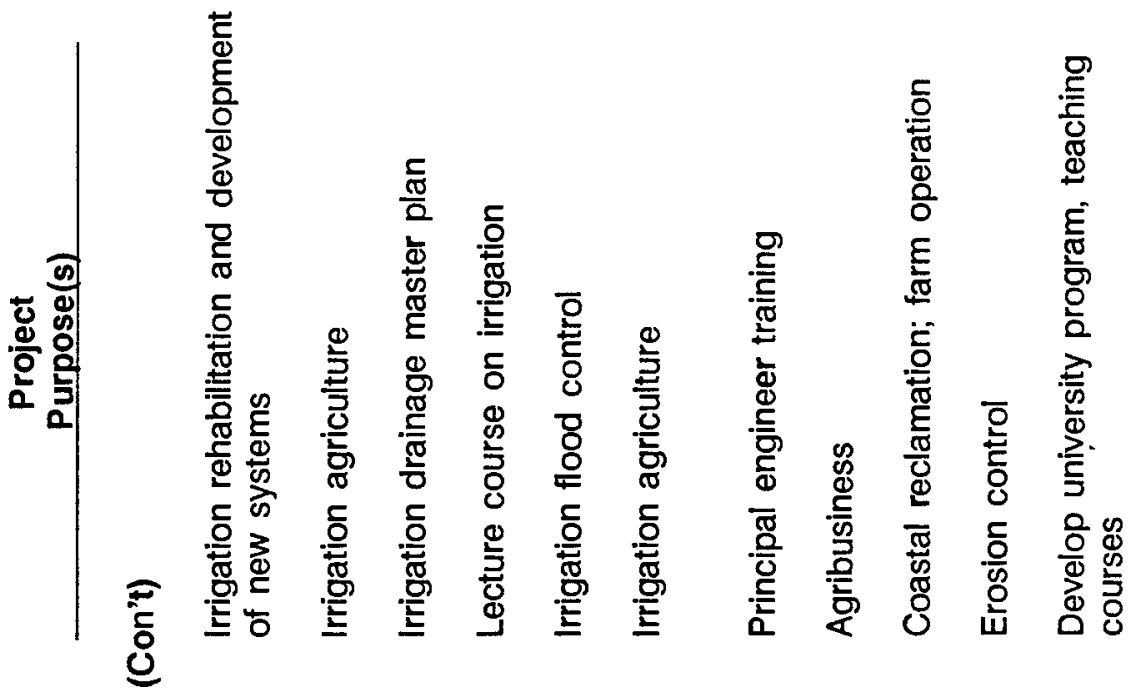

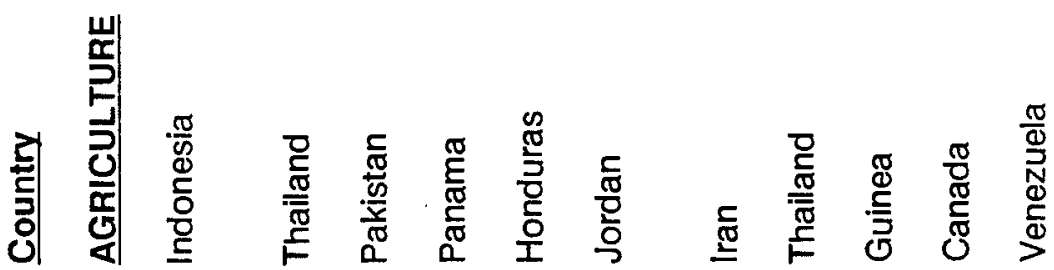




\title{
QUALIFICATIONS FOR DAM REHABILITATION ASSIGNMENTS
}

\author{
Corporate Experience
}

\section{General}

Harza has been a leading water resources engineering consultant since the firm's founding in 1920. To date, more than 100 dams have been built to Harza designs including some of the largest structures of their type in the world at the time of original construction. Nearly 200 projects have been either inspected by Harza staff or rehabilitated in accordance with Harza plans and specifications. Work has included involvement with nearly every type of dam including earthfill, rockfill, concrete gravity, buttress, arch, steel and concrete-faced dams, cribs, and various specialty steel sheetpile structures. Prior inspection work includes preparation of FERC Part 12 Independent Consultant's Safety Reports for 57 FERC-licensed projects during the last twenty years, along with a large number of inspection and rehabilitation assignments for water supply, flood control, cooling lake, and ashpond impounding structures in accordance with state dam safety regulations and design of dam safety improvements at Corps of Engineers projects as a Corps contractor. Four Harza staff members have been approved as FERC Independent Consultants for Part 12 Inspections.

As a result of this extensive experience, Harza offers consulting engineering services in a wide variety of dam inspection and rehabilitation fields including FERC Part 12 inspections; inspection and rehabilitation of water supply, flood control, and recreation dams in accordance with state dam safety regulations; evaluation of mechanical and electrical rehabilitation needs for gates and outlet works; design of stability improvements for earth and concrete dams; inflow design flood evaluation; design of auxiliary spillways for existing projects; remedial grouting for seepage control in concrete dams, earth dams, and tunnels of various designs; Probable Maximum Flood estimation; earthquake engineering for earth and concrete dams; underseepage control at earth dams utilizing filtered drains or extensive relief well arrays; and development of computerized instrumentation systems for dam performance monitoring. Experience highlights in these and related areas of potential interest are presented below.

\section{Post-Tensioned Anchor Design Experience for Stability Improvement of Gravity Dams}

Modern dam safety regulations for existing dams often result in the need for stability improvement at many older projects, especially concrete gravity dams. Post-tensioned anchors are a common means of achieving the safety factors presently required by many 
regulatory agencies. Harza's experience in post-tensioned anchor design and installation assistance is unsurpassed. Twelve assignments have been completed since 1965. Prior anchor assignments have involved difficult drill rig setup, use of barges for access, or helicopters for placement of tendons in the hole.

Prior Harza post-tensioning projects include anchors at the Wanapum Project (WA), Utah Power and Light's Oneida Dam (UT), Tacoma City Light's Cushman Dam, the New York Power Authority's Hinckley Dam, Northeast Utilities' Shepaug and Stevenson Dams (CT), Crown Zellerbach's Elwha and Glines Canyon Dams (WA), the City of New York's Boyd's Corner Dam, Pennelec's Piney Dam, the Corps of Engineers' Mississippi River Lock and Dam No.1, Soda Dam (UT), and Washington Water Power's Long Lake Project. All the above projects except Boyd's Corner and Lock and Dam No. 1 were subject to FERC review. Projects with anchor systems under design include Mead Paper's Boney Falls Project (MI), Springfield Utilities' McDaniel Lake Dam (MO), Sabine River Authority's (TX) Iron Bridge Dam, and the Fairfax County Water Authority's Occoquan Project (VA).

\section{Coring for Evaluation of Gravity Dam Foundation Interface Shear Strength and Foundation Uplift}

Gravity dam stability improvement commonly requires geotechnical evaluation of shear strength at the concrete/rock contact at the base of the dam and determination of uplift pressures by piezometer installation. Careful drilling and testing is required to obtain the necessary data. FERC has recently revised their guidelines to permit reduced factors of safety if detailed exploration programs are undertaken. Harza has been successful in obtaining relief from more stringent factors of safety as a result of detailed drilling and testing programs at several projects. Harza has completed 15 assignments in the last eight years involving coring for sampling and testing of the foundation interface of concrete gravity dams in support of anchor design or general stability analysis. Prior work includes investigations at Bridgeport Hydraulic Company's Means Brook and Samuel P. Senior Dams in Connecticut; Northeast Utilities' Stevenson and Shepaug Dams; the lock walls at Mississippi River Lock and Dam No.1; Pennelec's Piney Dam; Ford Lake Dam (MI); Mead Paper's Boney Falls Dam (MI); six dams for the City of New York including Boyd's Corner, New Croton, Croton Falls, Cross River, Titicus, and Sodom; and Soda and Oneida Dams for Utah Power and Light.

\section{Evaluation of Spillway Capacity Expansion Alternatives at Existing Projects}

A large portion of Harza's dam safety experience is related to identification of need for auxiliary spillway capacity and design of new spillway structures at existing projects. Options for spillway capacity expansion commonly involve consideration of new gated structures, design of fuse plug spillways, armoring dams with concrete or rollcrete to

900726

A900032P GRAND

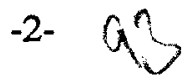


permit safe overtopping, or raising dams to increase head on existing spillways or contain flood waters.

Recent assignments of this type include Tacoma's Cushman Project where a fuse plug was approved by FERC, Wisconsin Electric's Brule Project where a fuse plug is now under design by Harza, studies and designs for the Corps of Engineers' Baldhill Dam Project in North Dakota, spillway expansion studies and designs for Mead Paper's Boney Falls Project (MI), studies and designs for 14 dams in the City of New York water supply system including Boyd's Corner Dam where construction is now in progress, and studies and designs for new spillways at the Cheyenne Water Board's Granite and Crystal Dams where fuse plugs have just been constructed to Harza designs.

In addition to the above, Harza prepared a study of spillway capacity expansion alternatives for Utah Power and Light's Viva Naughton Project in 1988, and is presently involved in design of a new fuse plug controlled side channel spillway for Wisconsin Electric's Brule Project in upstate Wisconsin. The Brule Project also involves complete overhaul of the existing gated spillway and replacement of all spillway piers. The Boney Falls project involves design and construction of a rollcrete auxiliary spillway.

Nearly all of the spillways at the 100 or more Harza designed dams were designed by in-house hydraulics engineers. To date, Harza has designed over 65 new gated spillways for some of the largest projects in the world. In-house capabilities include development and supervision of hydraulic model tests when appropriate.

\section{Probable Maximum Flood Studies}

Evaluation of spillway capacity adequacy at existing projects involves knowledge of the magnitude of the Probable Maximum Flood. Harza has undertaken over 75 other PMF studies worldwide. Studies have included work based on National Weather Service (NWS) generalized probable maximum precipitation data (PMP) from NWS Hydrometeorological Reports, and site specific PMP studies. Site specific PMP studies have been accepted by FERC and occasionally result in reduced PMF's when compared with peaks generated using HMR's.

\section{Effects of Dam Overtopping on Stability}

Harza has participated in several studies of the effects of overtopping on stability of concrete dams during floods including evaluations at the Denver Water Board's Lake Cheesman and Strontia Springs Dams, and at Tacoma City Light's Alder Dam. 


\section{Dambreak/Incremental Stage Rise/Inflow Design Flood Studies}

Many dam safety agencies now accept inflow design floods less than the PMF for existing projects if the results of dam break/flood wave modelling show that the effects of hypothetical dam failure in downstream areas is insignificant. Harza has been involved in some of the most complex dambreak/flood wave studies for project specific inflow design flood (IDF) identification ever submitted for FERC review. Most of this work involves application of the National Weather Service DAMBRK computer program. The Brule Project IDF study in Wisconsin involves eight dams on the same river and evaluation of incremental stage rises and the consequences of dam failure for a suite of assumed inflow floods and spillway capacities for all the projects. Similar work on the Boney Falls Project has lead to FERC acceptance of an IDF less than the full PMF. Studies for Colorado Public Service's Cabin Creek Project are underway. Prior work has also included studies at 14 dams in the New York City water supply system, and dambreak studies for earthquake failure conditions at the Santee Cooper Project (SC) that led to FERC acceptance of a comprehensive emergency action plan in lieu of structural modifications.

\section{Earthquake Engineering for Dams}

Harza has been responsible for ground motion determination and stress evaluation on a number of FERC and NRC projects in recent years. Past assignments include dynamic, three-dimensional FEM studies for Tacoma's Cushman, Mossyrock, and Mayfield Dams, UP\&L's Cutler Dam, Washington Water Power's Cabinet Gorge Project, several U.S. Bureau of Reclamation Projects, and Hydro Quebec's Daniel Johnson Dam, the largest multiple arch buttress dam in the world. Applicable experience in earthquake engineering for embankment dams includes studies for the FERC-licensed Santee Cooper Project (SC), the cooling lake embankment at the South Texas Nuclear Project, and recently completed studies at Kentucky Lake and Ft. Loudon Dams for the Tennessee Valley Authority.

\section{Experience in Evaluation of Deteriorated Concrete}

Harza has extensive experience in evaluation and repair of deteriorated concrete including structures damaged by freeze-thaw, sulfate, attack, and alkali-aggregate reaction. Repairs have included epoxy crack grouting, chipping and replacement of concrete, blasting deteriorated concrete from the surfaces of gravity monoliths and piers, and complete reconstruction and replacement of complex hydraulic structures including tainter gate piers.

Harza has worked on two FERC-licensed projects that involve extensive alkali-aggregate reaction problems. The centerline of the gravity section at the Santeetlah Project (TN)

900726

A900032P GRAND

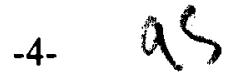


has actually risen and moved upstream as a result of expansion from alkali-aggregate reactivity. Harza studies of the Santeetlah situation have indicated that there are confining pressures above which alkali-aggregate reaction expansion in suppressed.

Other applicable prior experience includes extensive evaluation of freeze-thaw damage and remedial repairs at Cheyenne Water Board's Granite and Crystal Dams, reconstruction of gate piers at Pennelec's Piney Dam, replacement of waterstops at Mississippi River Lock and Dam No. 2, evaluation of extensive freeze-thaw deterioration at Eisenhower Lock on the St. Lawrence Seaway, repair of erosion damage at Warsak Dam (Pak) with fiber reinforced concrete, repair of cavitation damage in the low-level outlet tunnel at Painted Rocks Dam (MT), and resurfacing of all lock wall surfaces at the Corps of Engineer's Mississippi River Lock and Dam No.1. Controlled blasting techniques were employed. The freeze-thaw deterioration at Eisenhower has seriously threatened the integrity of the structure. Harza's Lock and Dam No.1 work won a Corps awarded as the best Corps engineering project in the U.S. in 1983.

Serious concrete deterioration at Wisconsin Electric's Brule Project, and at Utah Power and Light's Cutler Dam has resulted in the need for complete replacement of existing tainter gate piers in accordance with Harza designs.

\section{Design of Spillways on Engineered Fills}

Spillway capacity expansion studies commonly involve evaluation of the potential for paving or armoring earth dams to permit safe overtopping during major floods. Harza is presently involved in an assignment for the Corps of Engineers at Baldhill Dam in North Dakota that involves design of a spillway slab on an engineered embankment. The crest of the embankment at Baldhill will be excavated to about 3 feet below normal pool without reservoir drawdown, and the entire 1300 -foot-long, 50-foot-high embankment will be paved to permit overflow during major floods. The project is at the top of the list of Corps' projects with spillway deficiency problems. A drawing of the Baldhill slab and upstream diversion and cofferdamming scheme is included in the attached Supplemental Information. A rollcrete armoring scheme is presently under design for Boulder Colorado's Silver Lake Dam.

\section{Raising Dams for PMF Containment}

Many earth and concrete dams require raising to contain PMF headwaters, increase head and capacity of existing spillways, or provide adequate freeboard under extreme flood conditions. Harza has been involved in several such assignments in recent years. Recent Harza projects include raising the earth dam at Seattle City Water's Tolt River Dam by three feet using precast concrete highway median barriers. Cheyenne's Granite and Crystal arch dams (WY) were raised by up to 12 feet with new reinforced concrete

900726

A900032P GRAND

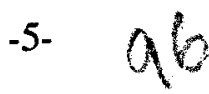


parapet walls. The gravity sections at Pennelec's Piney project were raised 5 feet. Portions of the concrete structures at Wisconsin Electric's Brule Project are scheduled for raising. A steel sheetpile wall 5 feet high has just been installed in accordance with Harza specifications at SCE\&G's Saluda Project (SC) for PMF containment. The Saluda installation involved nearly 1.5 miles of wall 5 feet high. Spillway capacity expansion designs for Mead Paper's Boney Falls Project involve raising the project's earth dams to increase spillway capacity. Earth embankments at the Brule Project will be raised and bolstered for PMF containment and to minimize effects of headwater seepage over the embankment core into the downstream shell during flood surcharge events. A new 5-foot high reinforced concrete parapet wall will be built on the Baldhill Dam embankment crest for added freeboard as part of overall spillway capacity expansion at the project. Studies for a similar structure are presently in progress at Utah Power and Light's Viva Naughton Project. All these design studies involved evaluation of structural alternatives, evaluation of freeboard requirements, embankment stability or seepage analyses, and flood routing studies.

\section{Fuse Plug Design}

Fuse plugs are becoming an increasingly attractive spillway capacity expansion option at many older projects. Harza has designed 10 fuse-plug spillways since 1962. Projects include spillways for Ross Barnett Reservoir (MS), Pennelec's Kinzua Pumped Storage Project (PA), the Guri Project in Venezuela, Burfell Project (Iceland), Granite and Crystal Dams (WY), the Denver Water Board's Strontia Springs Project, Bath County Pumped Storage Project (VA), and the New York Power Authority's Felts Mills Project. Fuse plugs for Wisconsin Electric's Brule Project and Utah Power and Light's Viva Naughton Project are presently under design. Fuse plugs at the Kinzua and Guri Projects eroded as predicted when overtopped by excess project inflow.

\section{Remedial Grouting}

Harza has extensive experience in remedial grouting for crack sealing, seepage control through concrete dams, foundation seepage control under concrete and earth dams, and for seepage control and ground improvement around tunnels of various designs. Work at the South Texas Nuclear Project Main Cooling Lake Embankment involved chemical grouting beneath spillway slabs to minimize potential for piping. Similar work was conducted in accordance with Harza specifications at the Corps of Engineers' Locks and Dams 1 and 2 on the Mississippi River after sounding for voids with pulse echo and ground penetrating radar.

Epoxy crack grouting experience includes work at Lock and Dam No.1 and at Pennelec's Piney Dam in Pennsylvania.

900726

A900032P GRAND
$-6-$

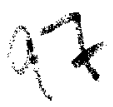


Ongoing grouting at New York City's Boyds Corner Dam involves extensive grouting inside the body of the 110-year old concrete dam and in the underlying foundation. Extensive grouting operations were conducted in Utah Power and Light's Electric Lake Dam to repair sinkholes in the embankment, and to control seepage in the underlying rock foundation.

Harza's recently completed grouting program in the power tunnels at the Bath County Pumped Storage Project (VA) was one of the most complex seepage control and consolidation grouting programs ever undertaken. High pressure grouting at up to $600 \mathrm{psi}$ was undertaken.

Harza experience in design of grouting programs includes work on over 100 new dams with grout curtains or remedial foundation treatment, and design and construction of nearly 195,000 linear feet of Harza-designed tunnels.

\section{Rehabilitation and Improvement of Mechanical and Electrical Equipment}

Harza dam rehabilitation experience includes evaluation of existing mechanical and electrical equipment, and design of improvements and replacements as necessary. Prior assignments include spillway rehabilitation at the Brule, Piney, and Cutler Projects described above, along with complete gate overhaul and height extension at Interstate Water Company's Lake Vermilion Dam (IL). The Brule work involved design of new gate hoisting equipment. Similar work was just completed for the Lower Colorado River Authority's Lake Brazos Dam (TX) on an existing bascule gate spillway. Typical assignments include design of new gate seal plates, gate seals, side seal heaters, and gate bubblers for ice control.

Recent low level outlet and sluice gate/valve designs include work at Cheyenne Granite and Crystal Dams, in New York at Boyds' Corner Dam, in Montana at Painted Rocks Dam, and in Colorado at several City of Boulder Dams, and at Rio Grande Dam where the entire outlet tunnel and sluice gate arrangement were reconstructed.

Prior work has also included detailed surveys and testing of mechanical and electrical equipment at existing projects and development of recommendations for replacement or upgrading as necessary. Detailed studies of this type have been conducted for the locks on the St. Lawrence Seaway, for Mississippi River Locks and Dams 1 and 2, and for spillway hoisting equipment at Baldhill Dam in North Dakota.

\section{Seepage Control}

Seepage control experience includes design of relief well and collector drain systems at numerous existing dams in addition to work associated with remedial grouting, slurry

900726

A900032P GRAND
$-7-$

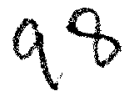


trench cutoffs, and repair of sinkholes in seepage blankets and liners. Over 13 miles of filtered underseepage collection ditch were designed by Harza for the South Texas Nuclear Project Cooling Lake Embankment. Work also included over 400 relief wells for additional seepage control. Filtered, pumped collection systems were designed for the cooling lake at the Dresden Nuclear Power Station (IL), portions of the ashpond dikes at the Four Corners Power Station (NM), and the Colleto Creek Station (TX).

Work has also included design of seepage control cutoffs for existing dams including corewall raising for the Boney Falls Project, a new steel sheetpile cutoff for portions of the cooling lake embankment at Dresden, and design of slurry trench cutoffs for a large number of dams including Wanapum Dam (WA) in 1965, Tilden Tailings Dam (MI), and Wissota Dam (WI) for Northern States Power. Harza has been a pioneer in slurry trench applications embankment dam seepage control at both new and existing projects.

Other seepage control assignments include design of seepage blanket/liner repairs at the Ludington Pumped Storage Project (MI), and at Tarbela Dam (Pak).

\section{Instrumentation Systems}

Review of the adequacy of project instrumentation systems and evaluation of data obtained is an important part of many dam safety assignments. Harza has been a pioneer in the design of computerized presentation systems for display of data from complex instrumentation systems. Work includes systems for compilation of readings for over 400 relief wells and 300 piezometers at the South Texas Nuclear Project, and several hundred piezometer and settlement monuments at the Bath County Pumped Storage Project in Virginia.

Powerton Station (IL), LaSalle County Nuclear Station (IL), Kincaid Station, Baldwin Station, the South Texas Nuclear Project, Cholla Steam Station (AZ), Four Corners Power Station, and Vermilion Station (IL).

\section{Earth Embankment Rehabilitation}

To date, Harza has designed over 50 earth or rockfill embankment dams and evaluated the stability and performance of hundreds of existing structures designed by others. Most of this work has been accomplished with in-house geotechnical staff. Experience includes layout, execution, and interpretation of geotechnical exploratory programs; stability analyses; evaluation of embankment failures; and design of new embankments or remedial works for existing structures. The Baldhill, South Texas, Brule, and Boney Falls projects described above all involved exploration, stability analysis and design of remedial works for stability improvement including new corewalls, slope flattening, or berm construction for downstream bolstering. Work has involved use of a variety of

900726

A900032P GRAND
$-8-$

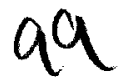


computer programs for slope stability and seepage evaluation. Assignments involving evaluation of embankment failures include study of the tailings dam failure at Churchrock Mine (NM), the tailings dam failure at Chino Mines (NM), and the cooling lake embankment failure at Florida Power and Light's Seminole Power Station.

\section{Risk Assessment}

Many dam safety regulatory agencies have begun to accept a risk assessment approach to determination of rehabilitation needs at older dams. Harza has staff with experience in dam safety risk assessment, and a formal working arrangement with Risk Assessment Consultants (RAC), the national leader in water resources risk assessment studies. $\mathrm{RAC}$ was responsible for a major risk assessment study involving 6 Utah Power and Light dams on the Bear and Hams Fork River that was presented to FERC as a basis for developing rehabilitation plans for the dams.

\section{Cofferdam Design}

Rehabilitation of older dams often involves consideration of cofferdamming and construction dewatering needs. Harza has designed a large number of earth and sheetpile cofferdams of various types including cellular cofferdams and unique space-saving sheetpile arc-backstay walls as discussed in the attached professional paper describing cofferdamming for new stilling basin construction at Miraflores Dam, Panama. Work has also involved design of temporary wellpoint systems including assignments at the South Texas Nuclear Project, and for initial construction of Calion Locks and Dam, Arkansas, for the Corps of Engineers.

\section{Operation, Maintenance, and Emergency Action Plans}

Development of operation, maintenance, and emergency action plans is an important part of many dam safety and rehabilitation assignments, along with the complex plans that are commonly prepared for new projects designed by Harza. Detailed operation and maintenance plans were prepared for the main cooling lake at the South Texas Nuclear Project, for the entire Bath County Pumped Storage Project, for the Corps' Baldhill Dam in North Dakota, and for many smaller dams owned by electric power utilities, water companies, developers, and state and federal agencies. Work commonly involves preparation of flood control operation plans and procedures for project operation during major floods. Plans of this type prepared in recent years include assignments at Interstate Water Company's Lake Vermilion Dam (IL), Woods Pond Dam (MA), and Ross Barnett Reservoir in Mississippi.

Nearly 40 emergency action plans have been prepared for existing projects in the last 5 years including assignments for Jersey Power and Light's Yard's Creek Pumped Storage

900726

A900032P GRAND
$-9-$

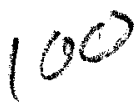


Project, Pennelec's Piney Project, two Scott Paper Company dams in Wisconsin, 5 dams in Minnesota for Power, and 14 major impoundments owned by the City of New York. Assignments have included plans prepared in response to both FERC and state dam safety agency requirements.

\section{Divers Inspections and Non-Destructive Testing}

Underwater inspections and non-destructive testing of various project components is an important part of many dam safety assignments. To date, Harza has been responsible for development and supervision of over 25 diver's inspections and several remote operated vehicle and mini-submarine inspections. Assignments include work at many of the projects described in previous paragraphs including 14 New York City water supply impoundments and Mossyrock and Mayfield Dams in Washington state.

Experience in non-destructive geophysical testing programs includes pulse-echo and ground penetrating radar for detection of voids behind tunnel liners and beneath slabs, electrical resistivity surveys for seepage detection, side scan sonar and precision fathometer surveys for detection of reservoir bottom irregularities, and ultra sound surveys of penstock and water conveyance pipelines. Applicable experience includes detailed geophysical surveys for voids and ground condition behind the tunnel liners at the Bath County Pumped Storage Project (VA), tunnel liner soundings at the Corbett Irrigation Tunnel (WY), pulse echo surveys for voids beneath slabs at Mississippi River Locks and Dams 1 and 2, resistivity surveys for seepage identification at the Boney Falls and Ludington Pumped Storage Projects(MI), reservoir bottom surveying at Ludington, and penstock/water pipe testing at Occoquan Dam (VA) and 6 power dams owned by the City of Tacoma.

\section{Erosion Control}

Many dam projects suffer from erosion problems on the upstream slope and in the tailrace. Development of erosion control plans and rectifying erosion problems is a common task in many Harza assignments. Applicable experience includes tailrace armoring studies at Mossyrock Dam (WA) using precast concrete dolosse armor units, stilling basin repair at Warsak Dam (Pak) using fiber reinforced concrete, and stilling basin construction at Miraflores Dam (Panama). Applicable experience in upstream slope protection includes repairs to 5 miles of embankment at the Ross Barnett Reservoir Project (MS) after a hurricane, and design of a sacrificial erosion control berm and fabriform facing for portions of the upstream face of Cooper Lake Dam (AK) for Chugach Power in addition to riprap design for all new Harza designed projects. 
$\mathrm{H}^{2}$ arza Engineering Company is acutely aware of the immensity, urgency and complexity of the food supply problems of coming decades. To meet the continuing challenge of demand versus food supply around the world, basic natural resources-farmlands, fisheries, minerals, energy, air and water-must be conserved, developed, and better managed for the benefit of dependent populations.

C lients in nearly every state and 62 countries have engaged Harza for agricultural services to:

- increase food and fiber production

- maintain soil fertility

- improve farm income

- provide a higher standard of living for farmers and processors of farm produce

- develop farm settlement plans

T aking many forms, Harza's agricultural

development assignments have ranged from major projects such as development of multipurpose plans for an entire nation or geographical region, to simple, straightforward activities such as draining a swamp to bring more land into productive use.

ur experience has included:

- appraisal or feasibility-level studies on $\mathbf{3 0 . 6}$ million hectares ( 75.7 million acres), an area equal to the combined farm acreage of Illinois and Nebraska, or the country of Bangladesh

- soil surveys for more than 2.2 million hectares (5.4 million acres)

- land classification studies for 10.8 million hectares (26.7 million acres)

- designs for irrigation facilities for 8.5 million hectares (21 million acres)

- designs for drainage facilities for 2.3 million hectares (5.7 million acres)

W e have offered a full range of services for the development of water, land and energy projects for nearly 65 years. Harza's Agricultural and Irrigation Services professionals are ready to assist governments and businesses around the world to achieve their goals. 


\section{AGRICULTURAL AND IRRIGATION SERVICES}

\section{CONTENTS}

Harza's Professional Staff for Agricultural and Irrigation Services

How Harza Works

Regional and River Basin Planning

6

Land Development

10

Institutional/Management Studies

Computer and Remote Sensing Capabilities
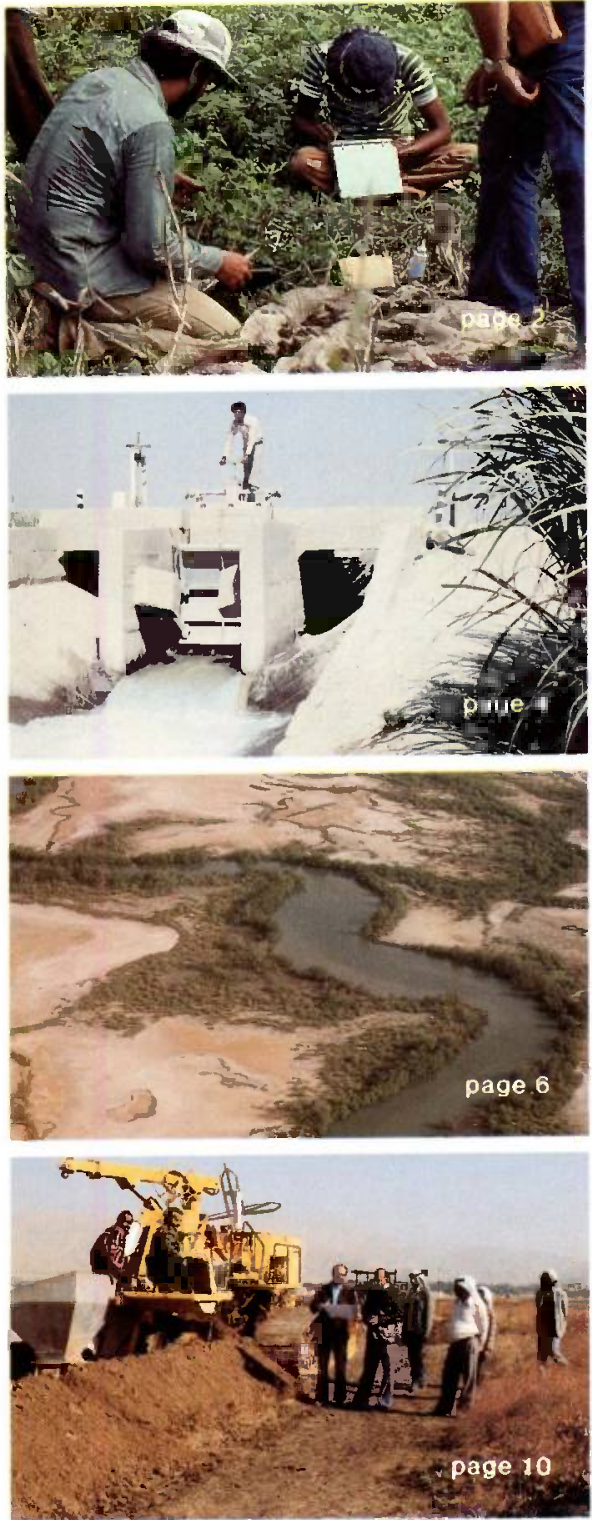

LARZA Engineering Company

Consulting Engineers 150 South Wacker Drive Chicago, Illinois 60606 (312)855-7000

Cable: HARZENG CHICAGO Telex 25-3540
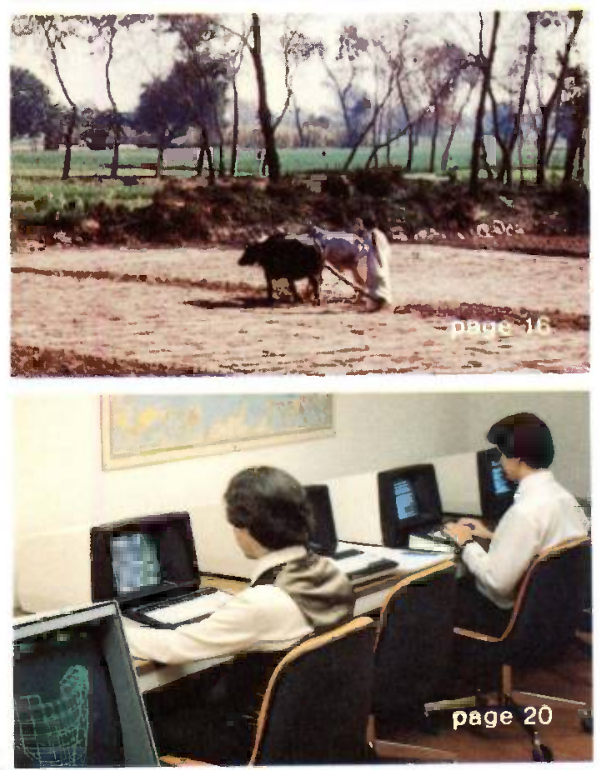


\section{HARZA'S PROFESSIONAL STAFF FOR AGRICULTURAL AND IRRIGATION SERVICES}

$\mathrm{H}$ arza Engineering $\mathrm{Co}$. is uniquely equipped to provide the wide range of experience and specialized talents required for modern land development. We maintain a staff which is fully represented in the major engineering disciplines and is amply complemented by scientists, farm planners, agronomists, ecologists and other specialists. Approximately 760 people are employed by Harza throughout the world. Of this total, two-thirds are professionals, including agricultural and environmental scientists, engineers and economists.

$\Delta t$ all levels, we focus on working on a one-to-one basis with our client's counterparts. Close liaison with our client's staff and custom training programs aid in the transfer of technology. This is provided at the highest levels on problems of agency organization, international financing and management; at the intermediate levels on engineering and agronomic matters; and at the farm level on water management, farm operation and training in new techniques.

- arza professionals represent many disciplines, many national origins. They have a single purpose: to assist each client in applying appropriate scientific agricultural development techniques in the most efficient, complete and cost-effective manner possible.
Saudi Arabia / Harza agricultural engineers used a variety of data collection methods to establish design parameters for agricultural water management (Dammam/Ghuwayba Agricultural Drainage)
In addition to this agricultural and general staff, specialists are available for the planning and design of other features of multiple-purpose developments, such as dams and spillways, hydroelectric power facilities, water supply treatment and conveyance systems, navigation

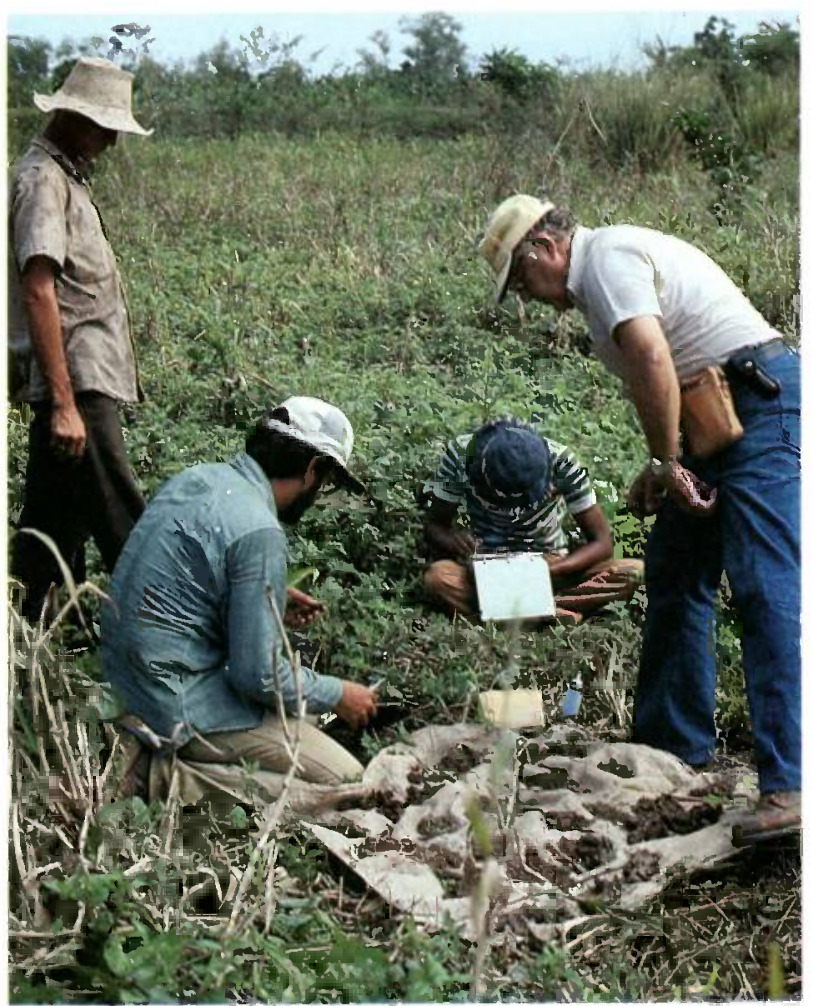

Honduras / Identification and analysis of soil horizons are important elements of soil surveys (Quimistan Valley).

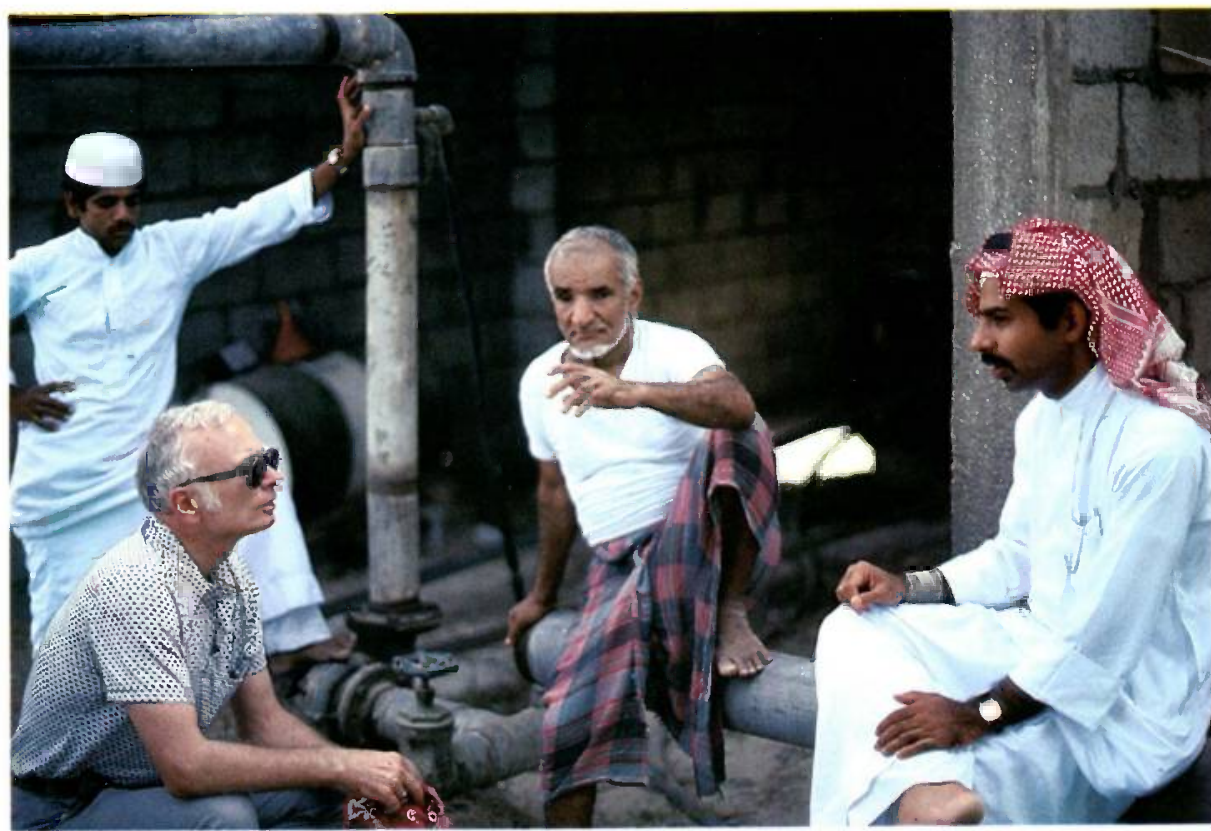




\section{AGRICULTURAL SPECIALISTS}

Agricultural chemists

Agricultural economists

Agricultural engineers

Agronomists

Animal scientists

Drainage engineers

Environmental analysts

Extension services specialists

Farm mechanization specialists

Foresters

Horticulturalists

Irrigation engineers

Land reclamation specialists

Marketing specialists

Resource economists

Resource planners

Watershed management specialists

\section{SUPPORTING SPECIALISTS}

Civil engineers

Electrical engineers

Geohydrologists

Geologists

Hydrologists

Hydraulic specialists

Mechanical engineers

Recreation planners

Systems analysts

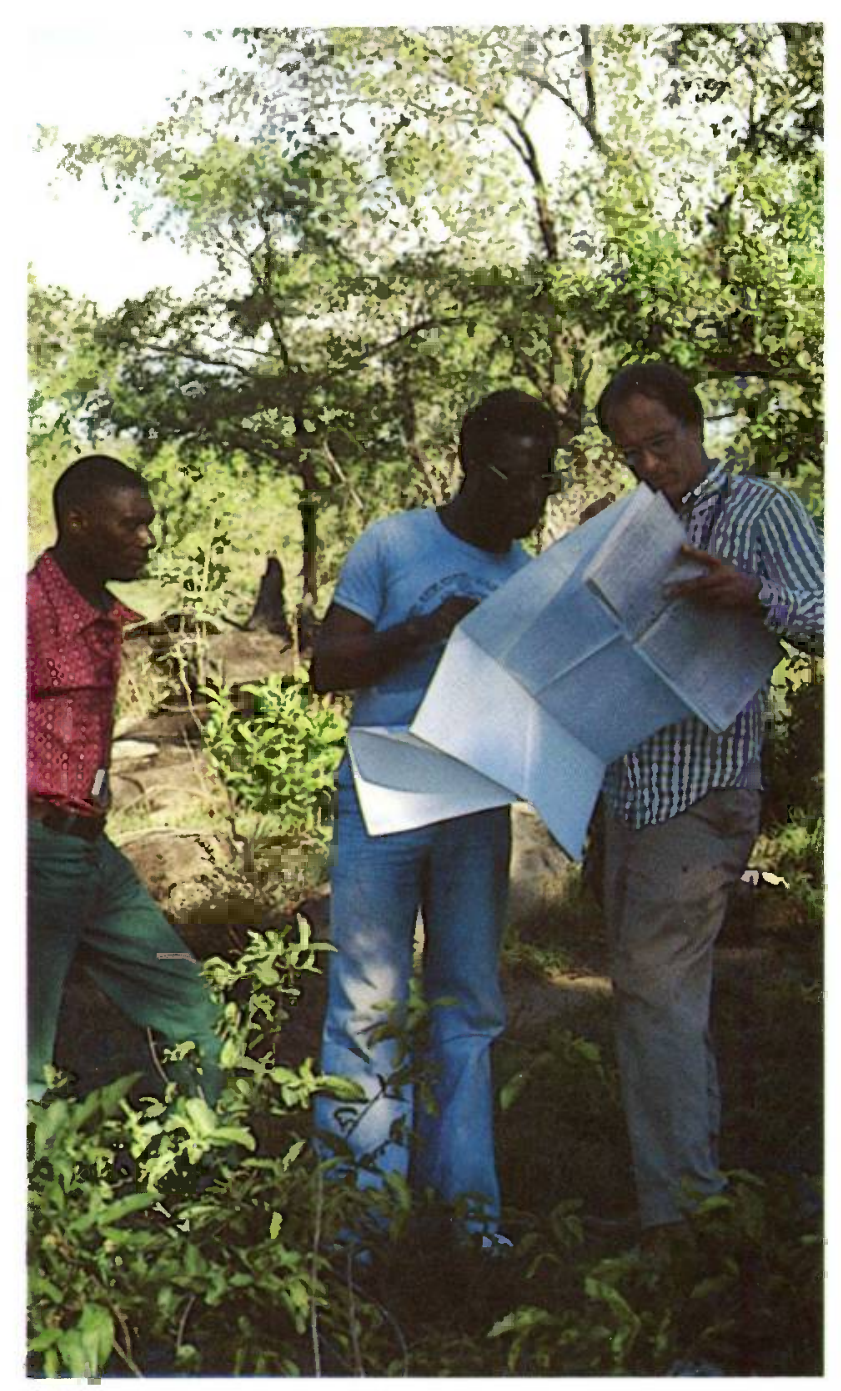

Tanzania / Plant resources were inventoried to develop an appropriate program for resource utilization (Reservoir Bush Clearing Study-Stieglers Gorge Project).
Jordan / Training of our clients' staffs is an important function of many of Harza assignments. (Jordan Valley Agricultural Drainage).

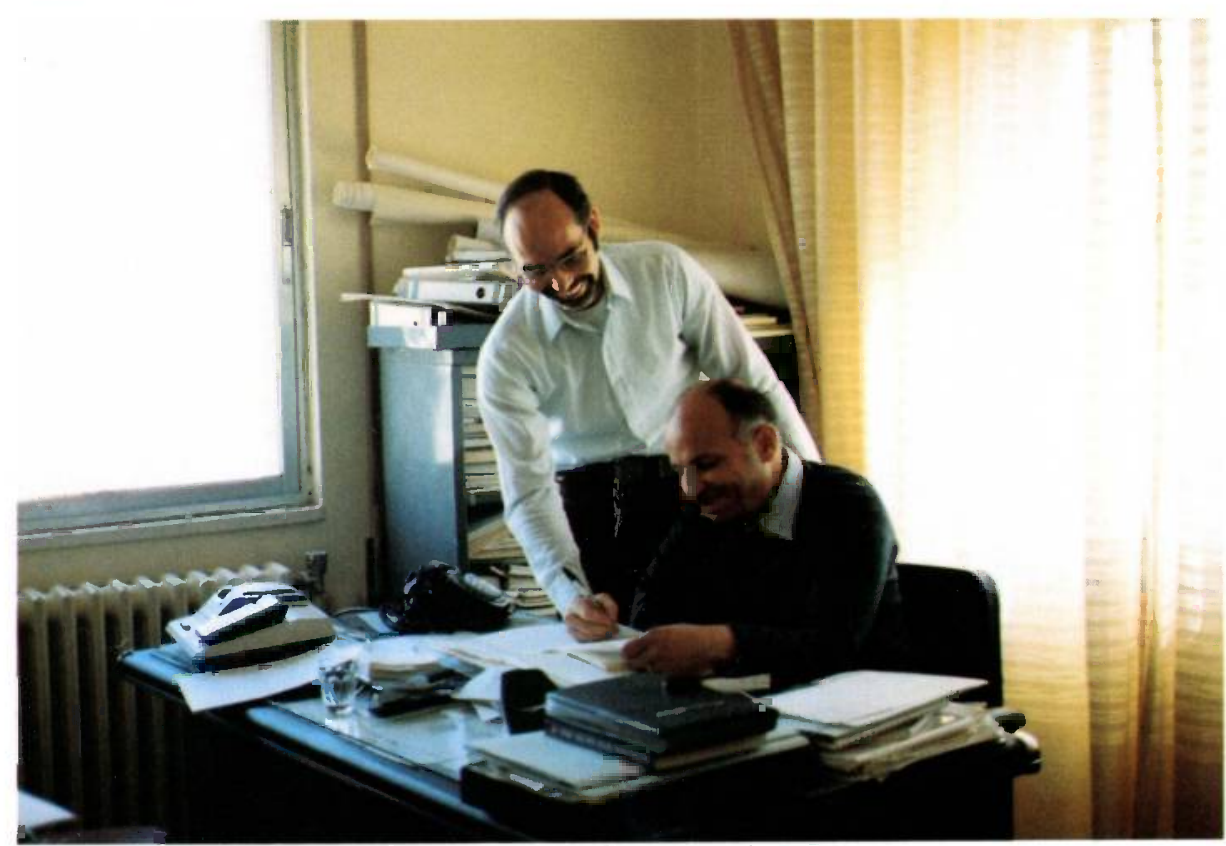




\section{HOW HARZA WORKS}

\section{PLANNING ... SELECTION ... DESIGN ... IMPLEMENTATION \\ AGRICULTURAL PROJECT DEVELOPMENT}

The planning process provides ample opportunity for both the client and Harza personnel to develop, review and modify development and design criteria before the program gets underway. In a typical assignment, Harza specialists work closely with client personnel and often with one or more associated firms; tasks are assigned to qualified personnel and all facets of the project are appropriately considered in a systems context.

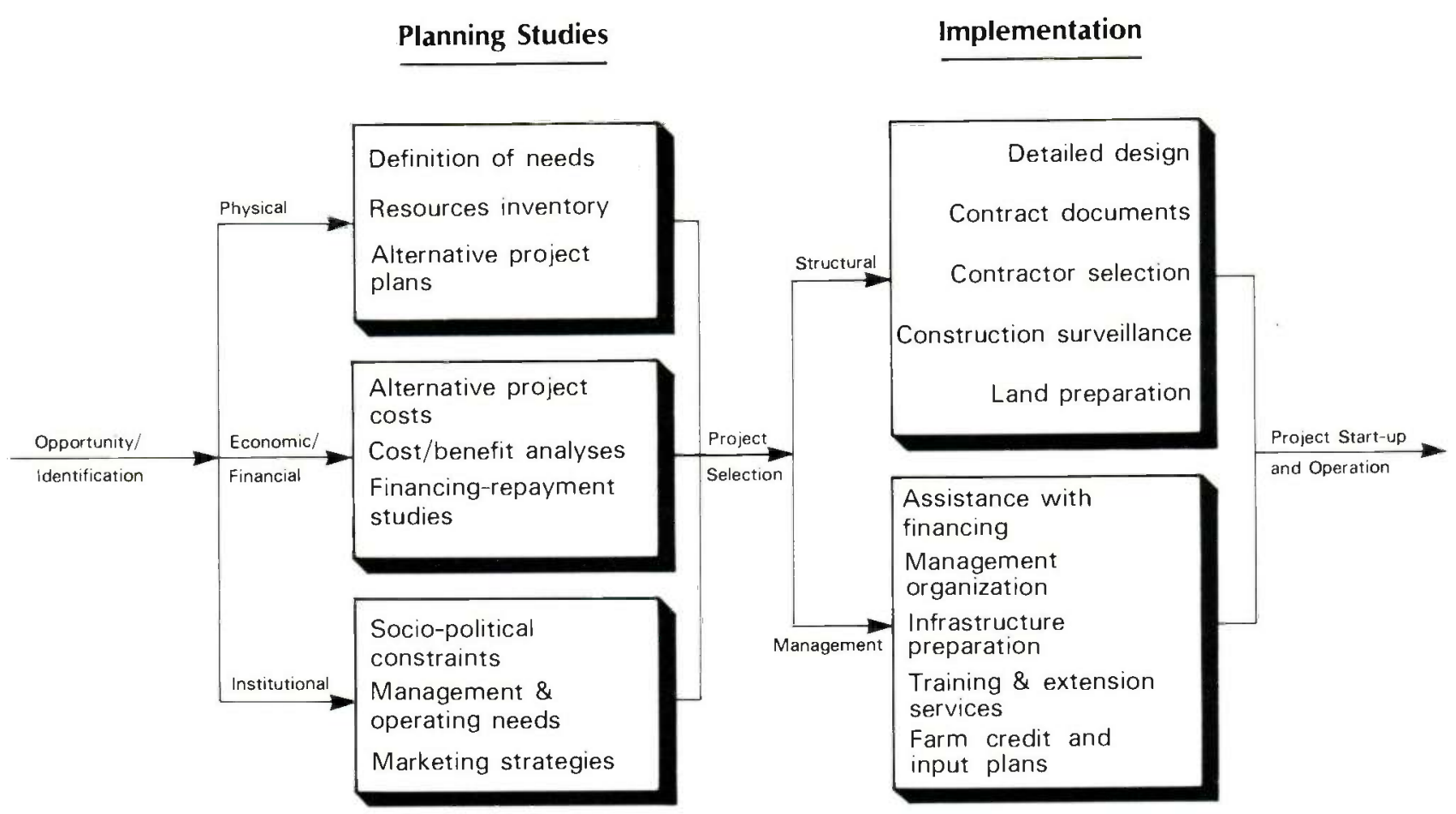

Iran / Harza designed, prepared tender documents and assisted during construction of this first stage river and land development project (Gotvand).

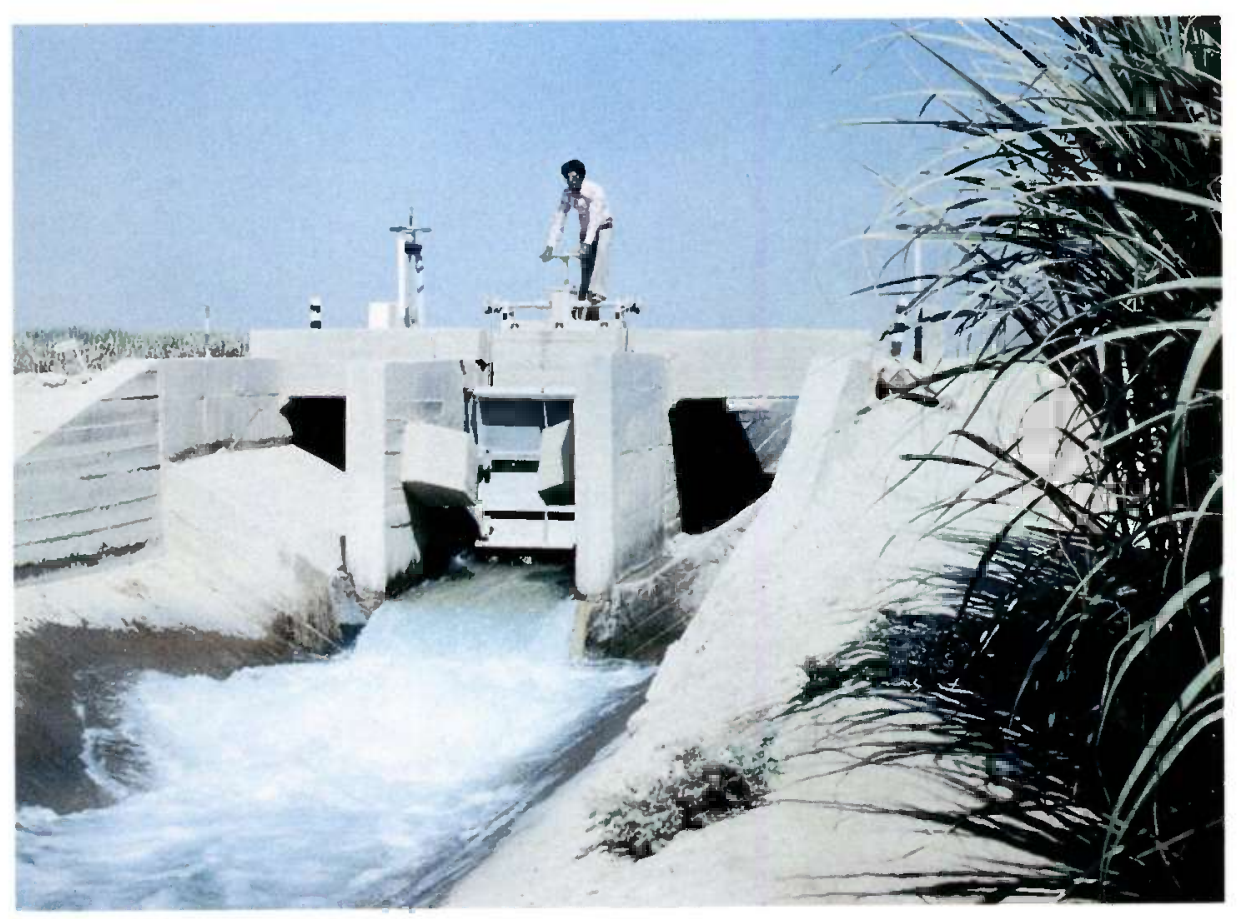




\section{Plan Selection and Project Report}

arza team members analyze
a wide range of alternatives and provide recommendations from which the client can make an informed decision. The project report reflects the way the information is to be used, usually including a summary of conclusions and recommendations followed by the more detailed project report. Appendices, which contain the basic data and special studies on which the report is based, are always provided for the use of client personnel.

\section{Project Design and Implementation}

$\mathrm{H}$ arza provides all or any part of the services required for project design and implementation throughout the world. Preparation of detailed design drawings, the most labor-intensive phase of engineering services, is frequently carried out by engineers and draftsmen of a local associated firm or may be carried out by the client's staff. Specialists furnished by Harza advise and train local technicians and review work during production. Our professionals are also involved in the preparation of contract documents, contractor selection, and rendering services during construction. We are experienced in major projects involving international construction and supply firms, as well as projects completed entirely by local contractors, or by the client.

T he initial operation of a project, particularly where irrigation facilities are being introduced, can be critical to its success. Harza will provide the necessary specialists to train project operators and farmers, assist with farm and water management, help establish extension services, advise on infrastructure operation, and initiate farm credit and cooperative programs.

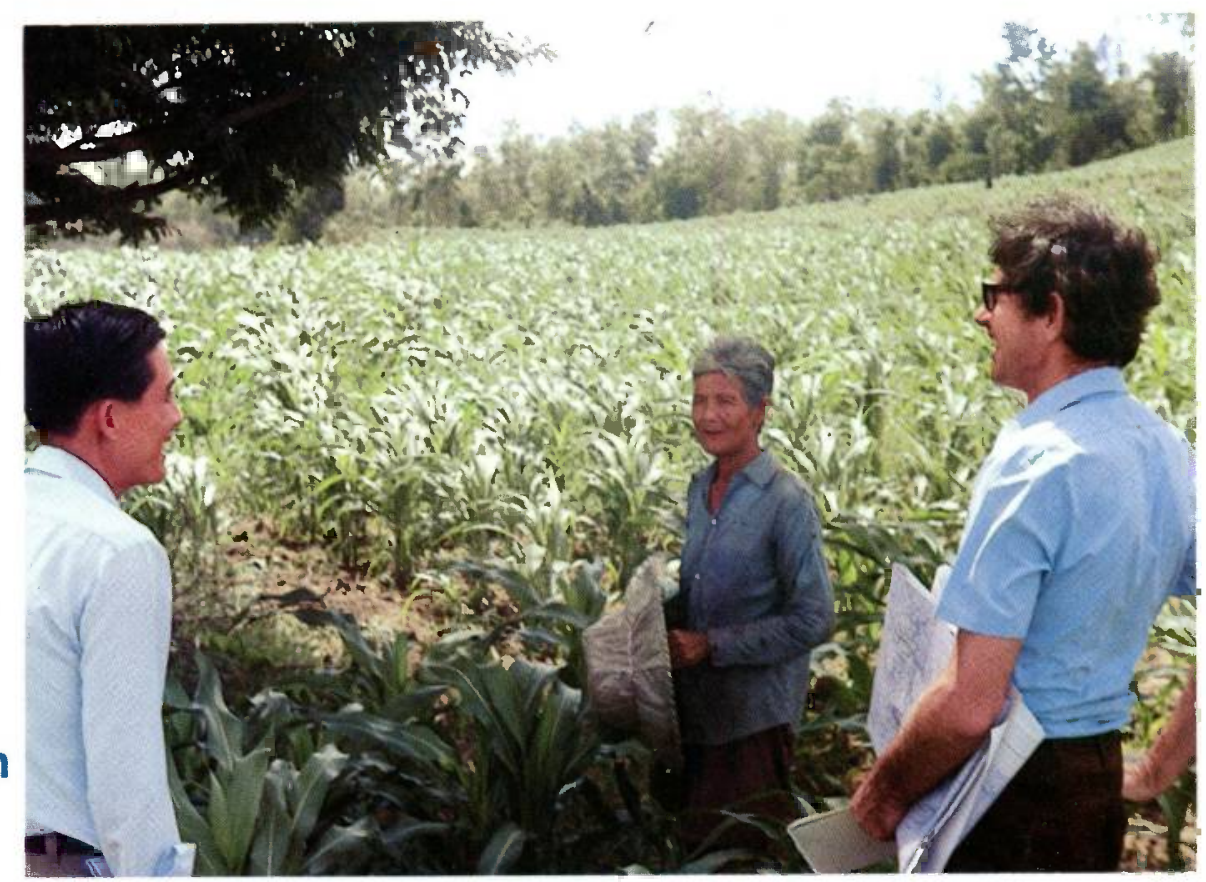

Thailand / Farm surveys established current farming practices and provided the basis for agronomic, economic and financial plans (Nam Mun and Nam Chi).

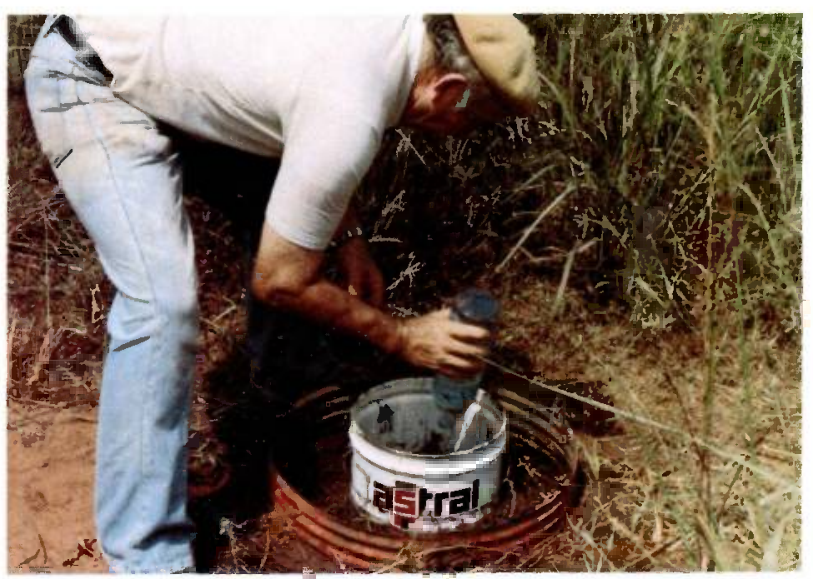

Senegal / Infiltration test yields basic soil data for land development. Harza's soil survey activities include such testing procedures that lead to the determination of land resources capabilities. (Lower Casamance Master Plan). 
$F^{\prime}$ rom the 140,000 square kilometer Indus Basin irrigation system in Pakistan, to the 20,200 square kilometer western New York State region, Harza has completed more than 600 assignments in the U.S. and abroad in the past 40 years involving irrigation, water quality management, water supply, flood control, hydroelectric development, and navigation and harbor facilities.

ith the client's planners and
administrators, objectives are established for a regional study of needs and potentials that could include:

- water supply

- land use

- increased crop production

- irrigation development

- reclamation

- flood control

- land settlement

- water quality management

- hydroelectric generation

- existing and potential recreation areas

Qegional and river basin projects require many diverse disciplines and a wide range of services, including water control and storage, development of groundwater sources, irrigation and drainage, flood control and other supporting agricultural services.

Warza agricultural/irrigation specialists work with clients to assure maximum project success by thorough conceptual planning. This planning process includes benefits from all reasonable objectives.

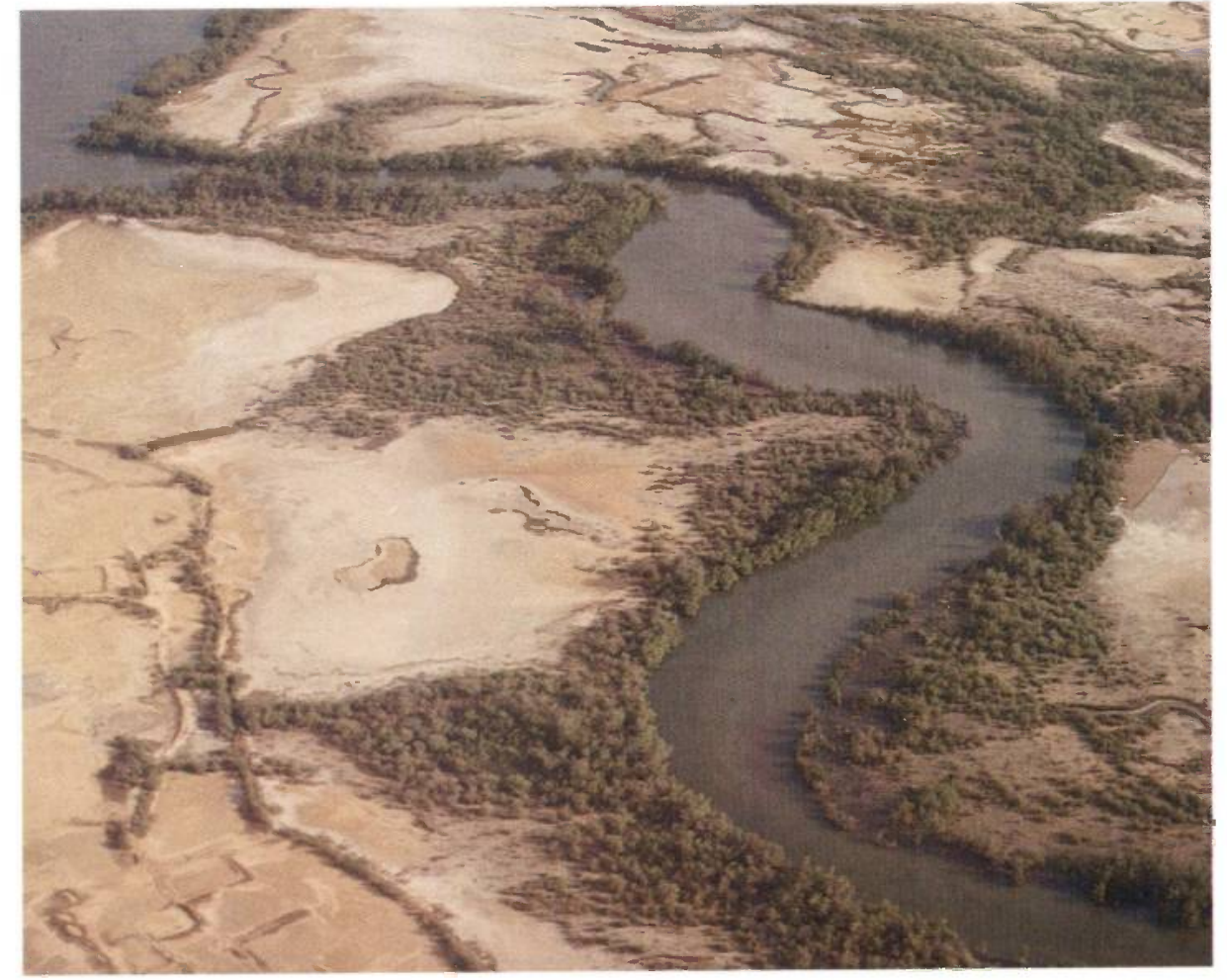

Senegal / The unique land and water resources of tropical tidal lowlands required careful study (Lower Casamance Master Plan).

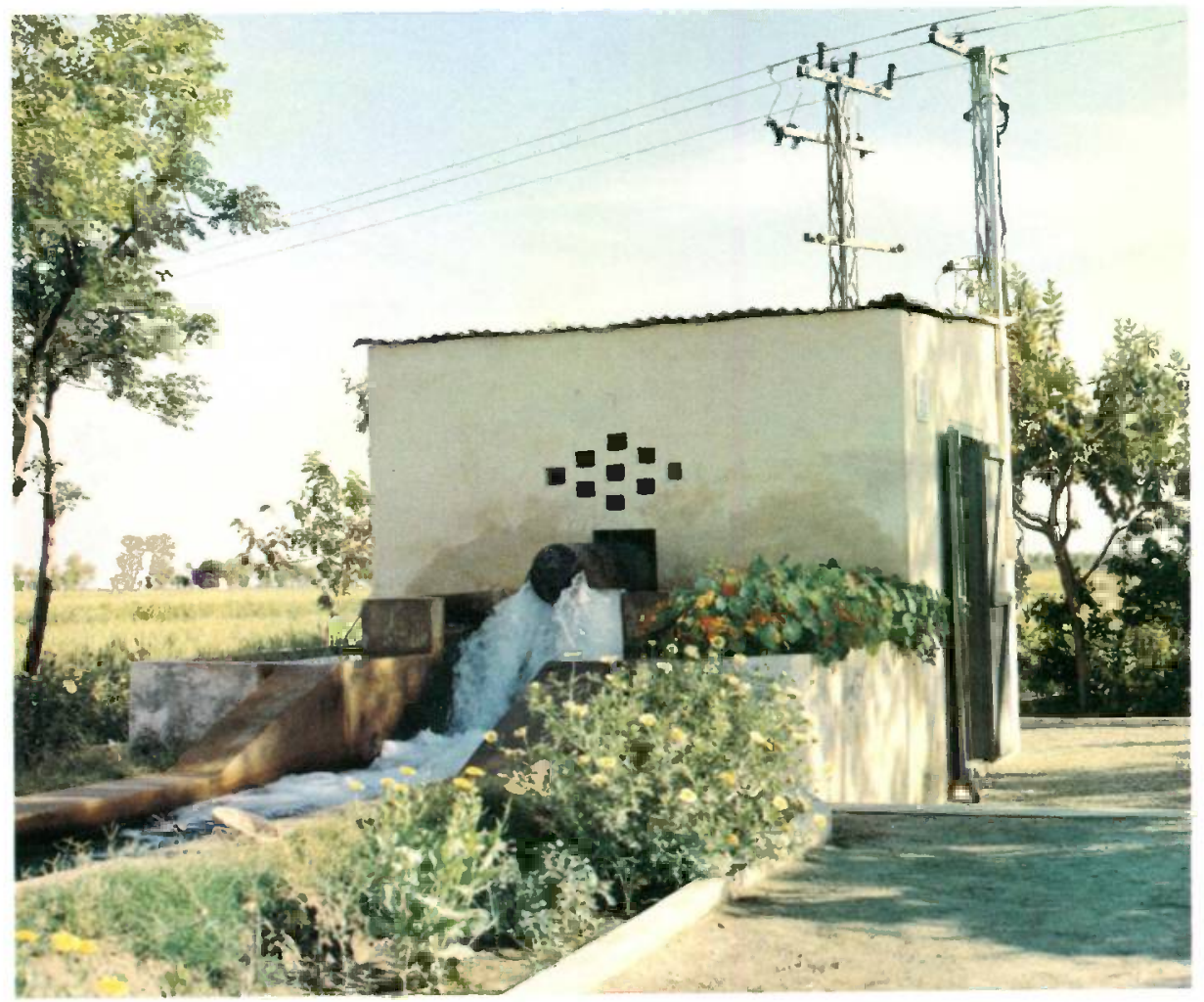

Pakistan / Wells for water supply and drainage are an essential ingredient for the development of the Indus River Basin. This 15-year plan encompasses the continuing development of agriculture, power and food control in a 14 million hectare area. 


\section{SERVICES}

Regional, river basin, or national reconnaissance surveys

Research of available data and reports

Aerial and on-site surveys, including interpretation of remote sensing data

Land-use mapping

Soil surveys and land evaluation

Resource inventories and evaluations

Hydrometeorological studies

Demographic and socioeconomic studies

Projections of regional and national needs

Inventories of existing facilities Identification of potential projects

Preparation and analysis of alternative development plans

Agronomic studies

Selection of priority projects

Preparation of long-term master plans

s part of our client services,
Harza has organized and participated in international consortia that bring together experts from around the world to study and evaluate regions and resources.

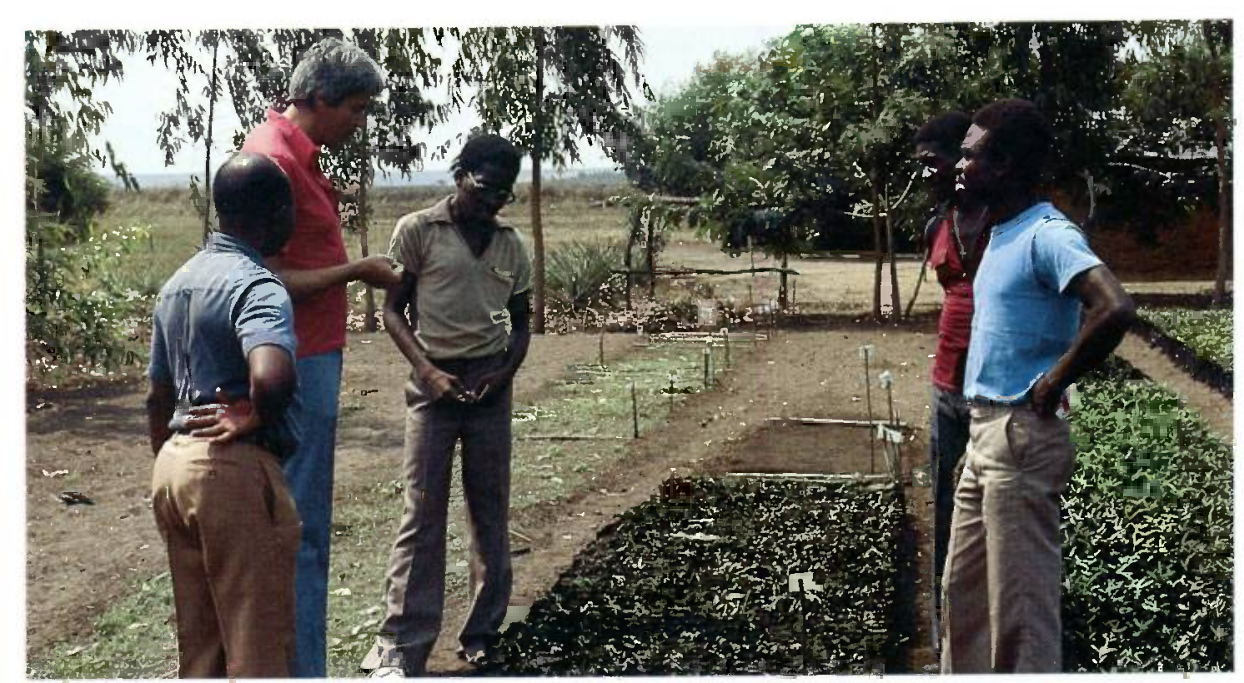

Zaire / Assessment of reforestation potential can be extremely helpful in evaluating characteristics of forest management (Zaire Environmental Profile).

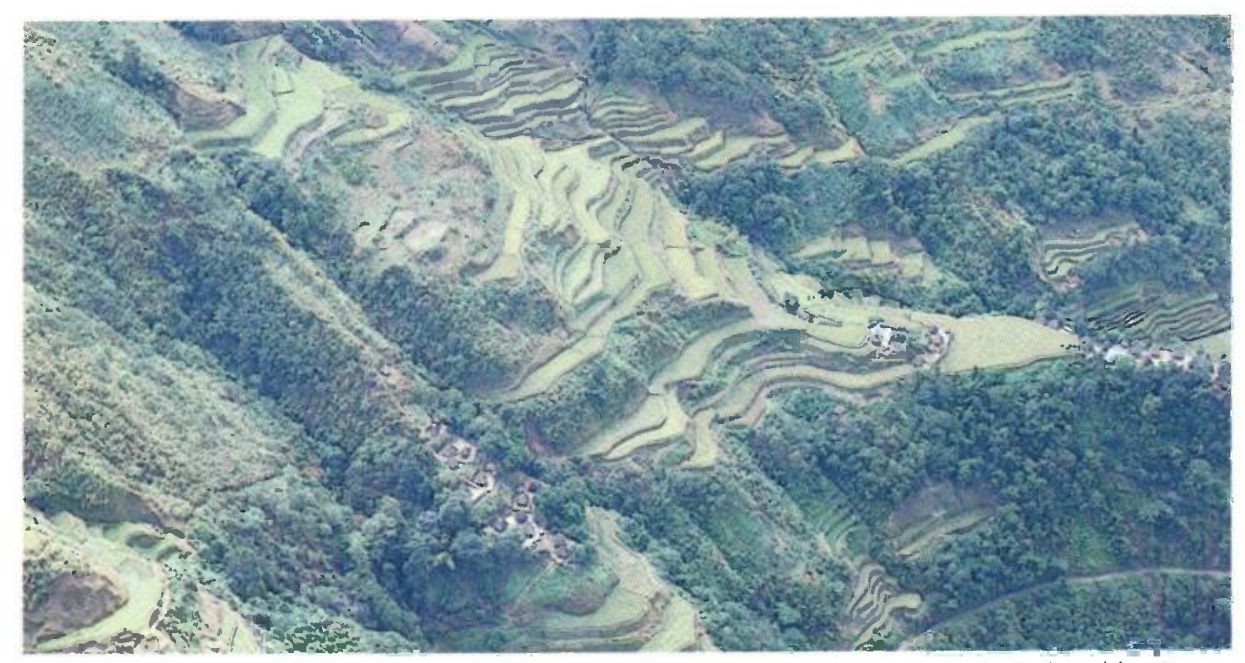

Philippines/Successful developments, such as the Banaue terraces, are studied to identify success and failure elements for proposed projects (Lusaran Dam Conservation Program).
Philippines/ The marketplace provides the information required to identify representative crops and marketing data for project evaluation (Luzon Watershed Management). 
REGIONAL AND RIVER BASIN PLANNING

\section{REPRESENTATIVE PROJECTS}

\begin{tabular}{|c|c|c|c|c|c|}
\hline Sponsor or Client & Project Name & Location & Description & Harza Services & Date \\
\hline $\begin{array}{l}\text { United States } \\
\text { New York State } \\
\text { Conservation Dept., } \\
\text { Division of Water } \\
\text { Resources }\end{array}$ & $\begin{array}{l}\text { Erie-Niagara Basin Master } \\
\text { Plan }\end{array}$ & Western New York State & $\begin{array}{l}\text { Plan for the development of water } \\
\text { and land resources through the year } \\
2020 \text {, including } 185,000 \text { acres } \\
(73,000 \text { ha) of irrigable land. }\end{array}$ & $\begin{array}{l}\text { Projection of agricultural needs, } \\
\text { evaluation of alternatives, layouts } \\
\text { and cost estimates, economic } \\
\text { analyses. }\end{array}$ & 1968 \\
\hline State of New York & Genesee River Basin Plan & New York State & $\begin{array}{l}\text { Comprehensive plan for } \\
\text { development of ifrigated agriculture, } \\
\text { water supply, and hydro generation. }\end{array}$ & $\begin{array}{l}\text { Resources inventory, evaluation of } \\
\text { alternatives, and preparation of } \\
\text { development plan. }\end{array}$ & $\begin{array}{l}1967 \\
1968\end{array}$ \\
\hline $\begin{array}{l}\text { Southeastern Wisconsin } \\
\text { Regional Planning } \\
\text { Commission }\end{array}$ & Root River Watershed & Wisconsin & $\begin{array}{l}\text { Formulation of comprehensive plan } \\
\text { for management of a watershed } \\
\text { changing from rural to urban. }\end{array}$ & $\begin{array}{l}\text { Hydrologic, hydraulic and economic } \\
\text { studies related to the overall plan. }\end{array}$ & 1967 \\
\hline $\begin{array}{l}\text { Argentina-Paraguay } \\
\text { Entidad Binacional } \\
\text { Yacyreta }\end{array}$ & Parana River Development & Argentina and Paraguay & $\begin{array}{l}\text { Multi-purpose development of the } \\
690-\mathrm{km} \text { reach of the Parana River } \\
\text { separating Argentina and Paraguay. }\end{array}$ & $\begin{array}{l}\text { Studies of hydro power, irrigation, } \\
\text { and navigation resulting in selection } \\
\text { of Yacyreta and Corpus projects." }\end{array}$ & 1972 \\
\hline $\begin{array}{l}\text { Bangladesh } \\
\text { Bangladesh Water } \\
\text { Development Board }\end{array}$ & $\begin{array}{l}\text { Water-sector Planning } \\
\text { Assistance }\end{array}$ & Bangladesh & $\begin{array}{l}\text { Preparation of guidelines for water } \\
\text { sector planning and assistance with } \\
\text { master planning. }\end{array}$ & $\begin{array}{l}\text { Study of needs of client organization } \\
\text { and assistance with strengthening } \\
\text { planning capability. }\end{array}$ & $\begin{array}{l}1980- \\
\text { present }\end{array}$ \\
\hline $\begin{array}{l}\text { Colombia } \\
\text { World Bank }\end{array}$ & $\begin{array}{l}\text { Upper Magdaiena } \\
\text { Watershed }\end{array}$ & Colombia & $\begin{array}{l}\text { Study of three subwatersheds (total } \\
194,000 \text { ha) to serve as pilot project } \\
\text { for } 5.6 \text { million ha watershed. }\end{array}$ & $\begin{array}{l}\text { Examine alternative soil } \\
\text { conservation, reforestation, land use } \\
\text { management, and extension services } \\
\text { programs. }\end{array}$ & $\begin{array}{l}1980- \\
1981\end{array}$ \\
\hline $\begin{array}{l}\text { Dominican Republic } \\
\text { Corporacion Dominicana } \\
\text { de Electricidad }\end{array}$ & Rio Bao Development & Bao River & $\begin{array}{l}\text { Study of possible irrigation } \\
\text { expansion with construction of Bao } \\
\text { Dam at Tavera Hydro Project. }\end{array}$ & $\begin{array}{l}\text { Feasibility-level investigations of } \\
\text { reregulating dam and potential } \\
\text { irrigation. }\end{array}$ & 1978 \\
\hline $\begin{array}{l}\text { Ecuador-Peru } \\
\text { Comision Mixta } \\
\text { Ecuatoriano-Peruan }\end{array}$ & $\begin{array}{l}\text { Puyango-Tumbes } \\
\text { Development }\end{array}$ & $\begin{array}{l}\text { Ecuador-Peru border } \\
\text { region }\end{array}$ & $\begin{array}{l}\text { Reservoirs and transbasin diversions } \\
\text { to supply } 140,000 \text { ha irrigation and } \\
520 \mathrm{MW} \text { power project. }\end{array}$ & $\begin{array}{l}\text { Study of alternatives, plan selection, } \\
\text { and teasibility studies, with } \\
\text { Ecuadorian and Peruvian } \\
\text { associates. }\end{array}$ & $\begin{array}{l}1976- \\
1977\end{array}$ \\
\hline $\begin{array}{l}\text { El Salvador } \\
\text { Ministerio de Agricultura } \\
\text { y Ganaderia }\end{array}$ & $\begin{array}{l}\text { Upper Lempa River Basin } \\
\text { Development }\end{array}$ & Northern El Salvador & $\begin{array}{l}\text { Identification of irrigation and } \\
\text { drainage projects totaling } 23,000 \\
\text { hectares. }\end{array}$ & $\begin{array}{l}\text { Reconnaissance-level soil surveys, } \\
\text { water supply studies, project } \\
\text { selection, and economic evaluation. }\end{array}$ & $\begin{array}{l}1965- \\
1966\end{array}$ \\
\hline $\begin{array}{l}\text { Guatemala } \\
\text { Consejo Nacional de } \\
\text { Planificacion Economica }\end{array}$ & $\begin{array}{l}\text { Water and Land Resources } \\
\text { Master Plan }\end{array}$ & $\begin{array}{l}\text { Chixoy, Ixcan, and Xalbal } \\
\text { Rivers }\end{array}$ & $\begin{array}{l}\text { Study of irrigation, hydro power, } \\
\text { water supply, and flood control in } \\
37,000 \mathrm{sq} \mathrm{km} \text { area. }\end{array}$ & $\begin{array}{l}\text { Identification and inventory of } \\
\text { potential projects and selection of } \\
\text { seven projects for early } \\
\text { development. }\end{array}$ & $\begin{array}{l}1970- \\
1971\end{array}$ \\
\hline $\begin{array}{l}\text { Honduras } \\
\text { Ministry of Communica- } \\
\text { tions, Public Works, and } \\
\text { Transportation }\end{array}$ & Sula Valley Master Plan & Honduras & $\begin{array}{l}\text { Flood control and agricultural studies } \\
\text { leading to development of } 60,000 \\
\text { ha of marginal lands. }\end{array}$ & $\begin{array}{l}\text { Hydrologic, agronomic, engineering, } \\
\text { and economic studies for valley } \\
\text { master plan. }\end{array}$ & $\begin{array}{l}1977 \\
1978\end{array}$ \\
\hline $\begin{array}{l}\text { Ministry of Natural } \\
\text { Resources }\end{array}$ & $\begin{array}{l}\text { Quimistan Valley } \\
\text { Development }\end{array}$ & Honduras & $\begin{array}{l}\text { Study of } 15,000 \text {-ha valley leading to } \\
\text { selection of most appropriate } 4000- \\
\text { ha irrigation project. }\end{array}$ & $\begin{array}{l}\text { Hydrometeorology, soils, alternative } \\
\text { layouts, agronomy, surface and } \\
\text { water supplies, and economic } \\
\text { analyses. }\end{array}$ & $\begin{array}{l}1977- \\
1978\end{array}$ \\
\hline
\end{tabular}

"Services provided in association with others.

Pakistan / Processing and transport are vital to project success (Revised Action Program).

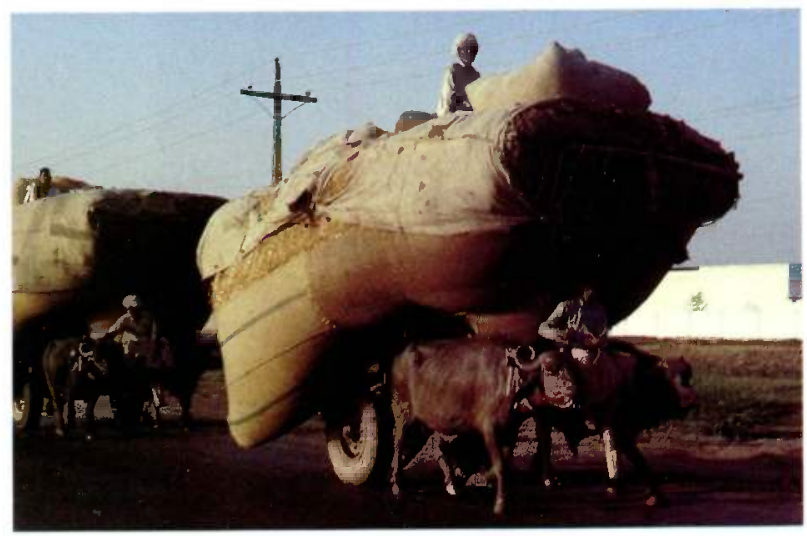




\section{REGIONAL AND RIVER BASIN PLANNING REPRESENTATIVE PROJECTS (Cont'd)}

\begin{tabular}{|c|c|c|c|c|c|}
\hline Sponsor or Client & Project Name & Location & Description & Harza Services & Date \\
\hline $\begin{array}{l}\text { Iran } \\
\text { Ministry of Water and } \\
\text { Power }\end{array}$ & $\begin{array}{l}\text { Karun and Marun River } \\
\text { Irrigation }\end{array}$ & Southern Iran & $\begin{array}{l}\text { Studies to identify potentially } \\
\text { ir rigable lands in the two river } \\
\text { basins. }\end{array}$ & $\begin{array}{l}\text { Soils, water supply, and economic } \\
\text { studies leading to selection of initial } \\
\text { and future projects. " }\end{array}$ & $\begin{array}{l}1966- \\
1967\end{array}$ \\
\hline $\begin{array}{l}\text { Iraq } \\
\text { Development Board of } \\
\text { Iraq }\end{array}$ & Hydrologic Survey of Iraq & Iraq & Hydrologic survey. & $\begin{array}{l}\text { Computerized simulation of river } \\
\text { basin for flood control and irrigation. }\end{array}$ & 1962 \\
\hline $\begin{array}{l}\text { Jordan } \\
\text { Jordan Valley Authority }\end{array}$ & $\begin{array}{l}\text { Yarmouk-Jordan Valley } \\
\text { Master Plan }\end{array}$ & Jordan & $\begin{array}{l}\text { Master plan for development of the } \\
\text { ir igation potential of the Jordan } \\
\text { Valley. }\end{array}$ & $\begin{array}{l}\text { Studies resulting in two-stage } \\
\text { development of water supply, } \\
\text { irrigation, and drainage facilities." }\end{array}$ & 1955 \\
\hline $\begin{array}{l}\text { Pakistan } \\
\text { Water and Power } \\
\text { Development Authority, } \\
\text { World Bank, UNDP }\end{array}$ & Revised Action Programme & Indus Basin, Pakistan & $\begin{array}{l}\text { Fifteen-year plan for continuing } \\
\text { development of agriculture, power, } \\
\text { and flood control in } 14 \text { million } \\
\text { hectare canal command area. }\end{array}$ & $\begin{array}{l}\text { Preparation of plan and schedule for } \\
\text { implementation; develop client's } \\
\text { capability to carry on planning } \\
\text { function. }\end{array}$ & $\begin{array}{l}1975- \\
1979\end{array}$ \\
\hline $\begin{array}{l}\text { Philippines } \\
\text { Cebu Water Board } \\
\text { World Bank (National } \\
\text { Irrigation Administration) }\end{array}$ & $\begin{array}{l}\text { Lusaran Dam Conservation } \\
\text { Program } \\
\text { Watershed Management }\end{array}$ & $\begin{array}{l}\text { Cebu Island } \\
\text { Luzon, Philippines }\end{array}$ & $\begin{array}{l}\text { Watershed management for } 6,000- \\
\text { ha watershed to reduce reservoir } \\
\text { sedimentation. } \\
\text { Land management in the } \\
90,000 \text {-ha Pantabangan and } \\
254,000 \text {-ha Magat basins to control } \\
\text { siltation. }\end{array}$ & $\begin{array}{l}\text { Watershed management planning } \\
\text { including agricultural and forestry } \\
\text { programs for erosion control and } \\
\text { income for residents. } \\
\text { Plans to reduce soil erosion, provide } \\
\text { livelihood for } 25,000 \text { people } \\
\text { displaced by reservoirs, and } \\
\text { produce revenues." }\end{array}$ & $\begin{array}{l}1979 \\
1980- \\
1981\end{array}$ \\
\hline $\begin{array}{l}\text { Senegal } \\
\text { Societe de Mise en } \\
\text { Valeur de la Casamance } \\
\text { (SOMINAC), U.S.AID }\end{array}$ & $\begin{array}{l}\text { Lower Casamance Master } \\
\text { Plan }\end{array}$ & $\begin{array}{l}\text { Lower Casamance region, } \\
\text { Senegal }\end{array}$ & $\begin{array}{l}\text { Plan for optimum development of } \\
\text { land, water, and human resources in } \\
\text { a one million heclare area. }\end{array}$ & $\begin{array}{l}\text { Preparation of master plan, feasibility } \\
\text { reports on sub-projects, and design } \\
\text { of initial project, including } \\
\text { sociological and infrastructure } \\
\text { needs. }\end{array}$ & $\begin{array}{l}1980- \\
1983\end{array}$ \\
\hline $\begin{array}{l}\text { Tanzania } \\
\text { Rufiji Basin Development } \\
\text { Authority }\end{array}$ & $\begin{array}{l}\text { Reservoir Bush-Clearing, } \\
\text { Stigler's Gorge Project }\end{array}$ & Southeast Tanzania & $\begin{array}{l}\text { Alternatives for clearing/utilization of } \\
\text { trees. }\end{array}$ & $\begin{array}{l}\text { Inventory of resources, development } \\
\text { of clearing and wood utilization } \\
\text { plans, economic analysis. }\end{array}$ & $\begin{array}{l}1980- \\
1981\end{array}$ \\
\hline $\begin{array}{l}\text { Zaire } \\
\text { U.S. Agency for } \\
\text { International } \\
\text { Development }\end{array}$ & Zaire Environmental Profile & Zaire & $\begin{array}{l}\text { Assessment of present and future } \\
\text { condition of natural and sociological } \\
\text { resources. }\end{array}$ & $\begin{array}{l}\text { Study of forest, marine and wildlife } \\
\text { resources. }\end{array}$ & 1981 \\
\hline
\end{tabular}

*Services provided in association with others.

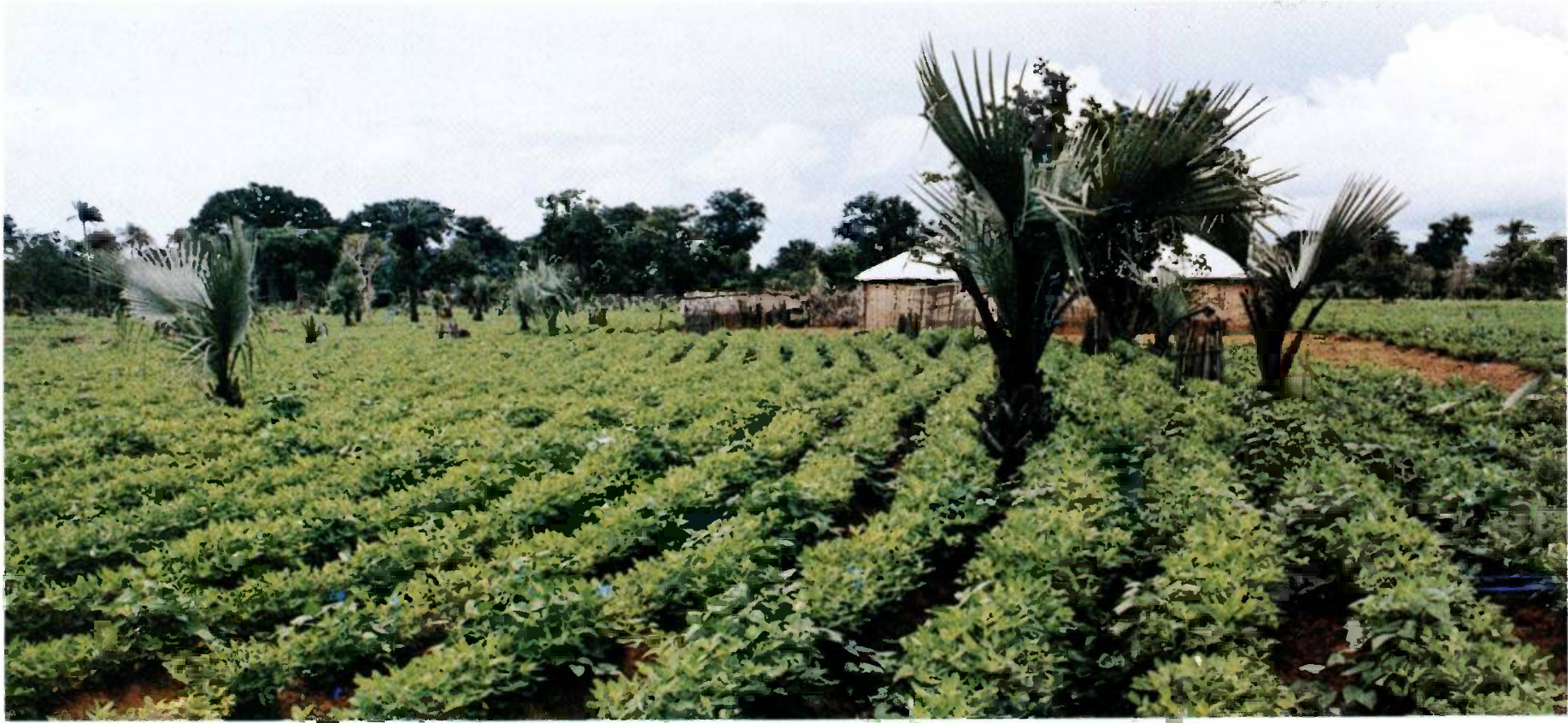

Senegal / Crops, such as groundnuts shown, are carefully selected to establish production input capability and appropriate benefit levels (Lower 


\section{LAND DEVELOPMENT}

\section{Project and farm planning ... irrigation and drainage ... land reclamation ... soil conservation and erosion control ... soil survey and land classification ... agronomy and agricultural engineering ... agricultural economics ... financial analyses}

roject and Farm Planning are major land resource development phases following regional plan completion. Harza assignments include feasibility and planning studies throughout the world, ranging from a feasibility study of the utilization of sewage sludge on Illinois farm land, to a full range of services in the rehabilitation and extension of rice irrigation projects in Indonesia.

rrigation and Drainage are important means of increasing food supply for expanding populations in many nations of the world. Harza provides: plans and designs for surface, sprinkler, and drip irrigation systems and for surface and subsurface drainage systems; determinations of crop water requirements and seepage and water conveyance losses; studies of water quality and water rights; engineering for groundwater development and for agricultural systems utilizing sewage sludge or wastewater.

and Reclamation experience of the Harza staff includes:

- leaching of salts

- land leveling

- management of water applications and withdrawals to maintain water and salt balances

- reclamation through application of sewage sludge as fertilizer and soil conditioner of unproductive coarse textured soils and areas disturbed by strip mining

These activities are designed to make poor lands suitable for cultivation and to restore productivity of lands previously under cultivation.

Qil Conservation and Erosion Control maintains or builds soil productivity while reducing soil loss. Harza services include:

- layout and design of erosion control systems (including bench terraces with tile outlets)

- determination of alternatives such as reforestation

- post-construction farm practice recommendations

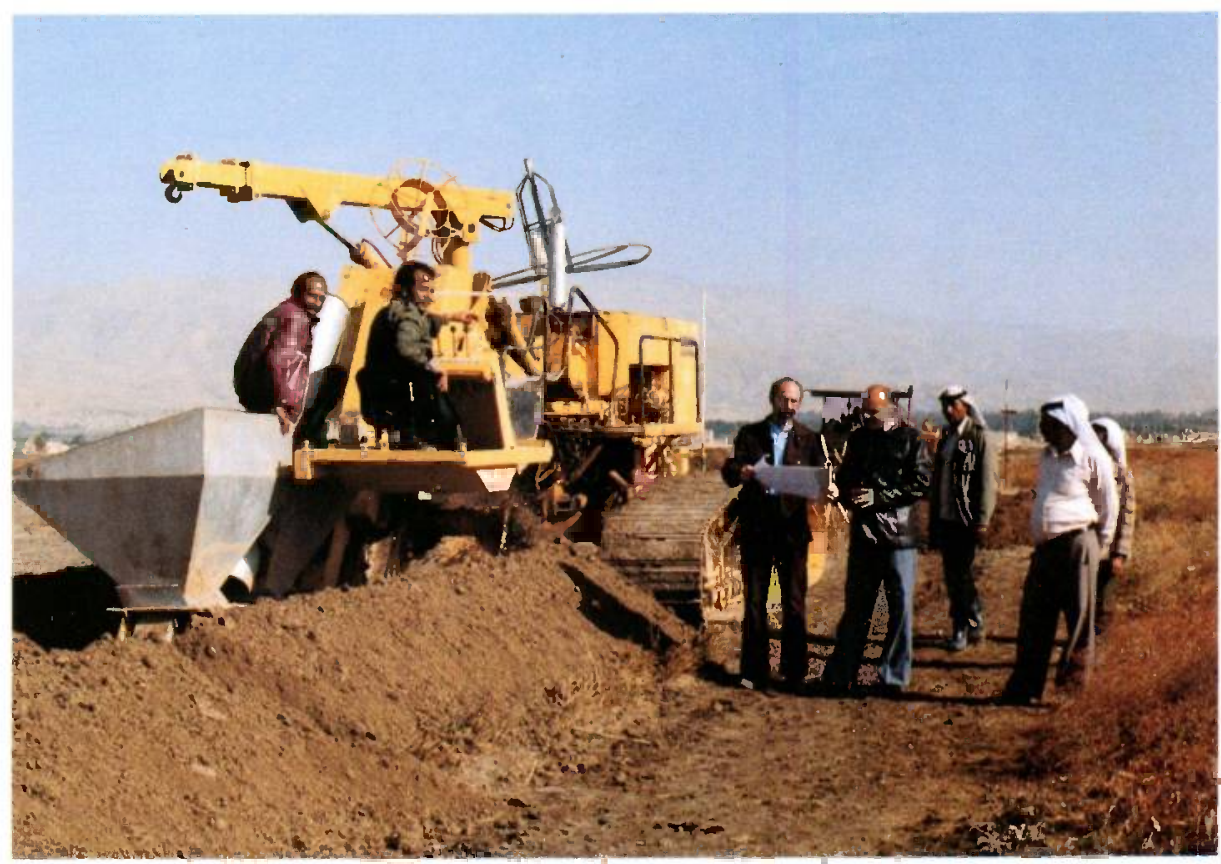

Jordan / Harza drainage specialists assisted client in formulating a drainage program and installing drainage improvements (Jordan Valley Subsurface Drainage).

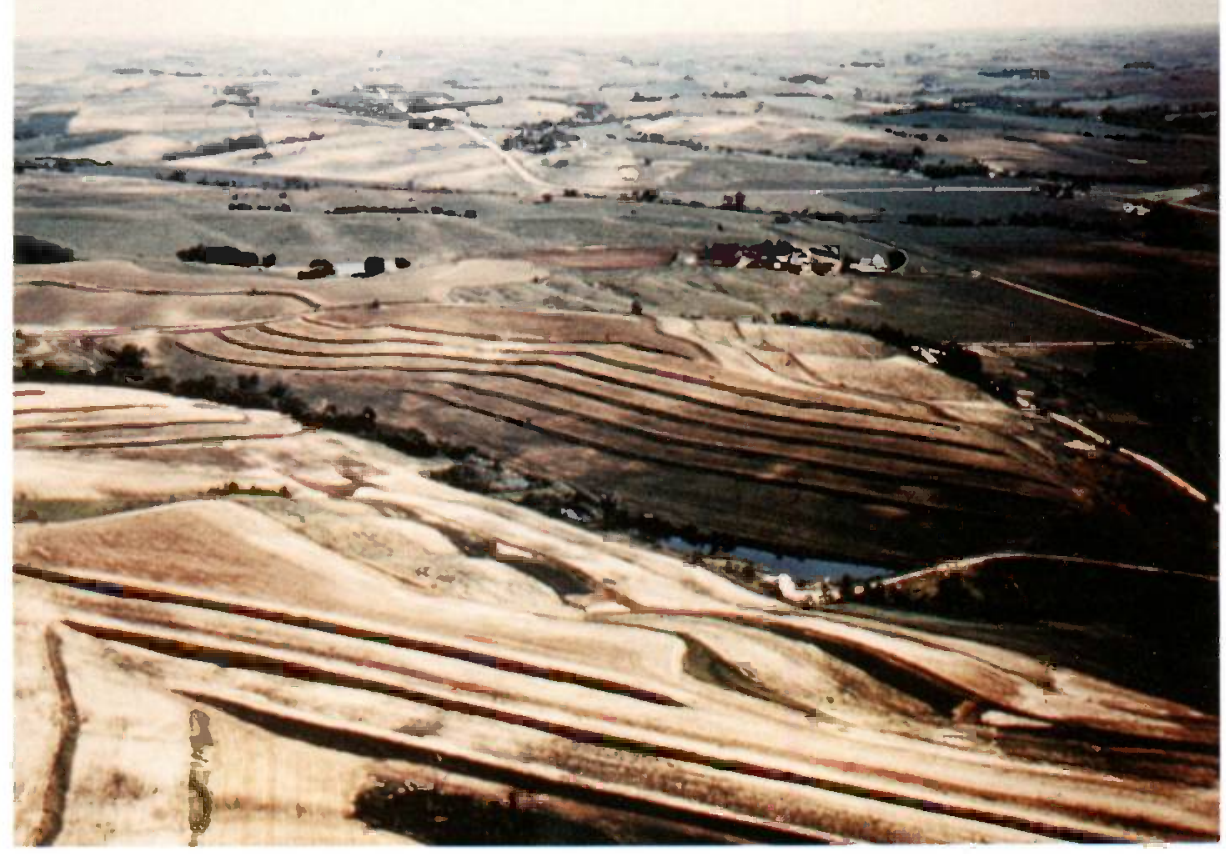

United States / Bench terraces are an important technique for soil conservation. (Farm development, lowa). 
So oil Survey and Land Evaluation are provided by the Harza staff for reconnaissance-level basin studies to identify important soil characteristics, plot on maps the boundaries between the various soil units. The classification (land evaluation) activities assess the suitability of land for various productive activities under consideration by client. development of the available soil, determine appropriate mechanization
Pakistan / Evaluation of irrigation systems leads to reduction in water losses and improvement in equity of distribution (Revised Action Program).

Jamaica / Development of new agricultural region required this major pumping facility (Black River Upper Morass).
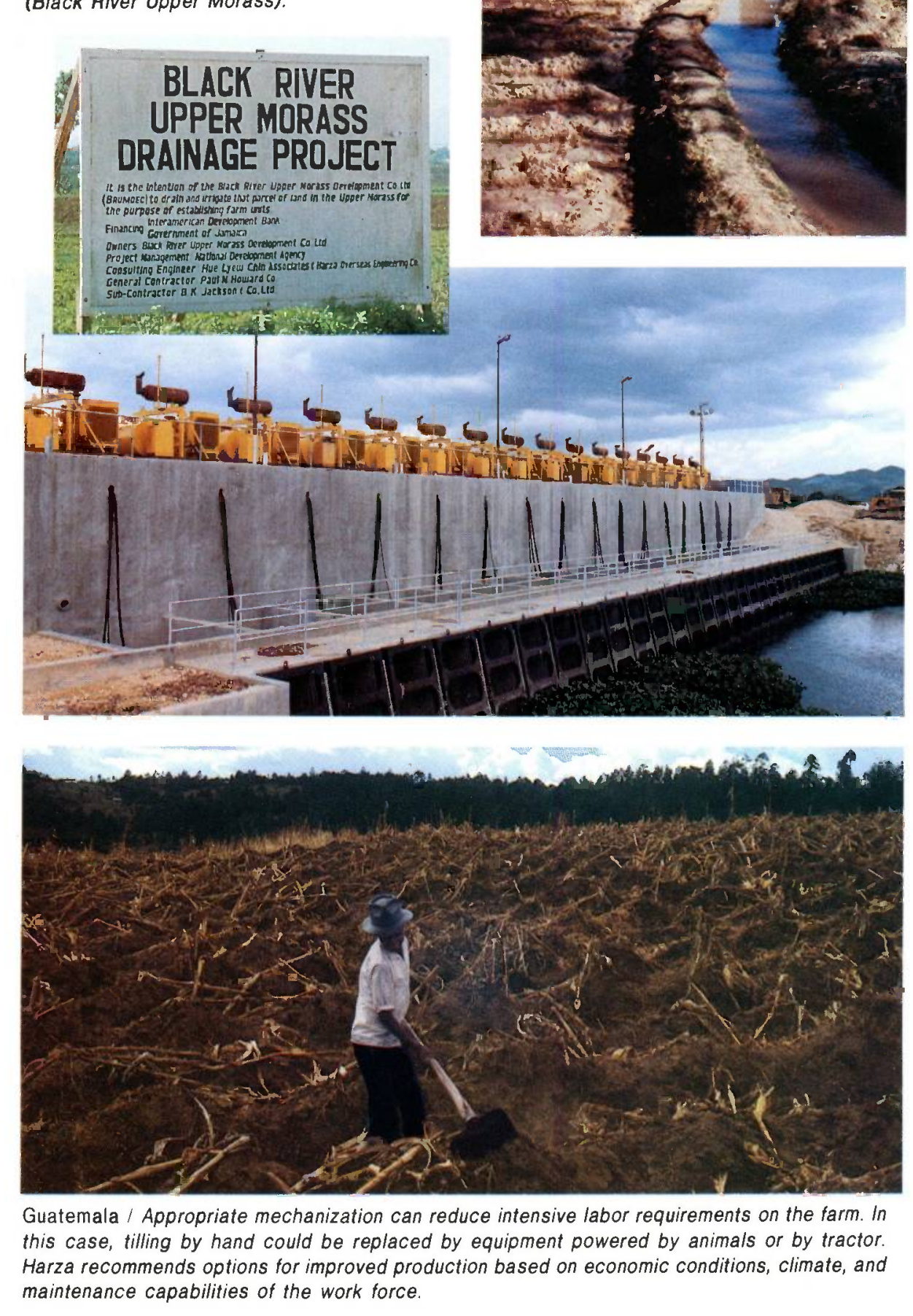

Guatemala / Appropriate mechanization can reduce intensive labor requirements on the farm. In this case, tilling by hand could be replaced by equipment powered by animals or by tractor. Harza recommends options for improved production based on economic conditions, climate, and maintenance capabilities of the work force.

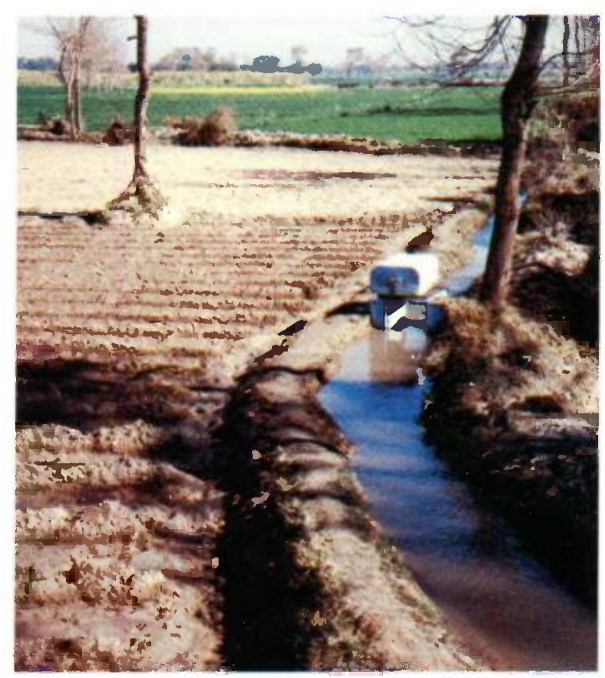
a wide range of purposes from detailed-level project designs. The inventory (soil survey) activities group the soils into defined units and Agricultural production classification considers soil survey results, agronomic and engineering alternatives, and economic and financial consequences.

$A$ gronomic studies identify and appropriate cultural practices, and cropping patterns most suitable for water and human resources.

Agricultural Engineering studies and labor requirements, crop storage and processing, transport, as well as irrigation, drainage, and erosion control methods.
$\Lambda$ gricultural Economics
identifies and compares costs and benefits resulting from a project. Market or financial prices of project inputs and outputs are adjusted to reflect true economic values, when necessary. The economic analyses may be used to compare alternative project designs and provide a basis for selecting the recommended project. Harza agricultural economists perform investigations covering three time categories: historic and present conditions; probable future conditions without the proposed project; and probable future conditions with the project in operation.
farm

\section{rece}
ancial analyses are and expenditures expected for the various project ons in both the private and and

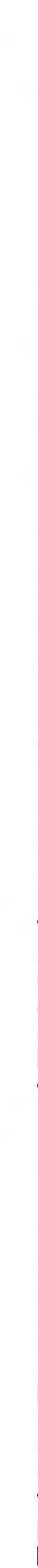




\section{LAND DEVELOPMENT}

\section{SERVICES}

\section{Appraisal, Feasibility, Financing}

- Soils and topographic surveys

- Agronomy and farm planning

- Inventory and inspection of existing facilities

- Determination of water use efficiencies

- Hydrology, hydrogeology, meteorology

- Water supply and on-farm water management facilities planning

- Non-agricultural aspects (hydro power, flood control, etc.)

- Environmental studies

- Social aspects, resettlement planning

- Formulation of alternative projects

- Preliminary costs estimates

- Marketing studies

- Infrastructure planning

- Economic analyses (cash flow, rate of return, sensitivity analyses)

- Assistance with external financing

\section{Design and Contract Documents}

- Project optimization

- Design criteria

- Geotechnical studies and materials testing for major structures

- Detailed design

- Contract drawings and specifications

- Tender documents for local, national, or international bidding

- Construction costs estimates

- Construction schedule

\section{Services During Construction and Start-up}

- Bid analysis, contractor selection

- Resident services during construction

- Review of design and testing of mechanical and electrical equipment

- Operation and maintenance manuals

- Personnel training, extension services

- Project start-up and certification

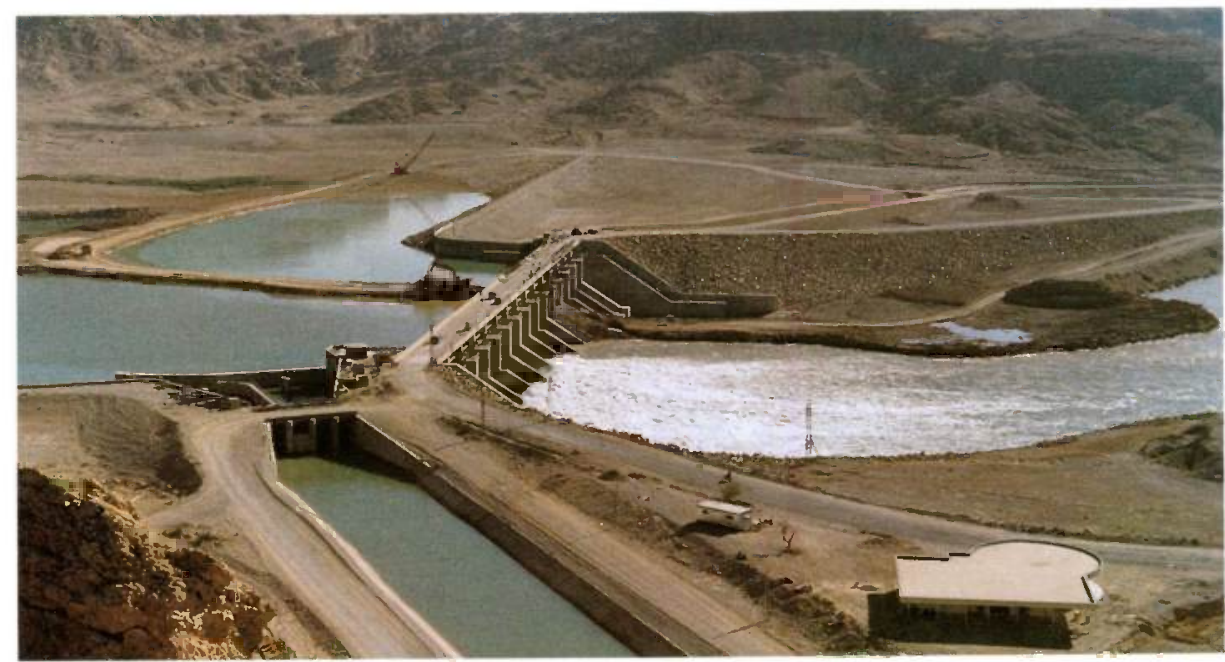

Iran / Major diversion works are successfully constructed after careful consideration of flow requirements, site conditions, materials and construction conditions (Gotvand).

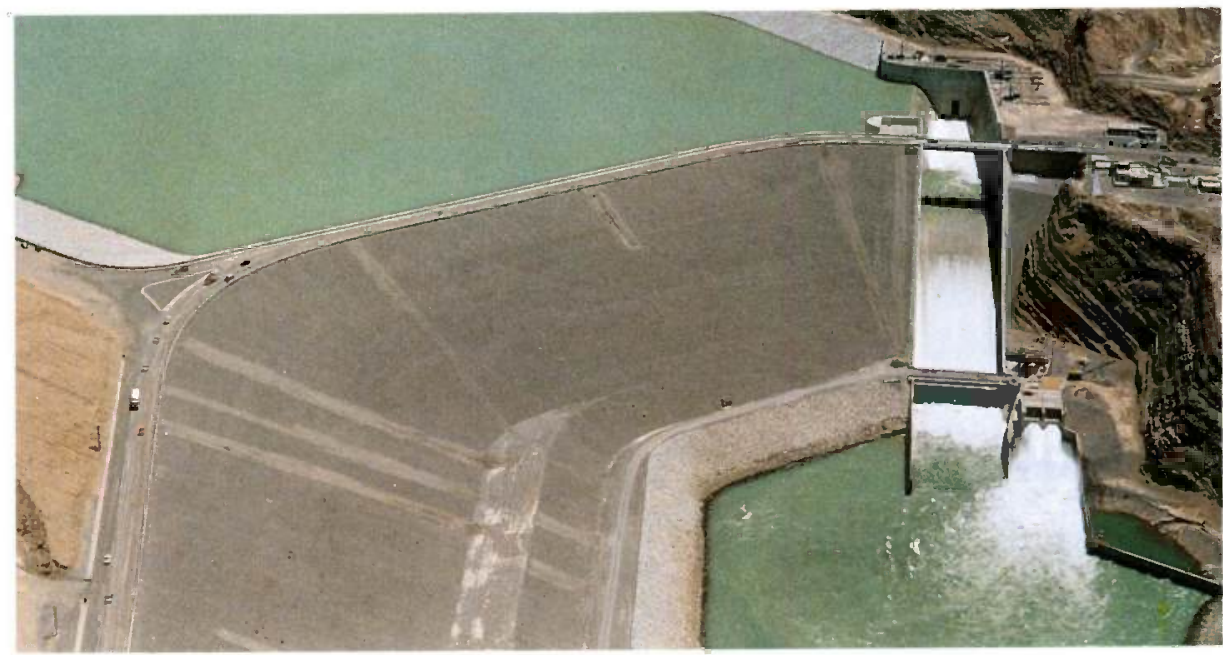

Argentina / One reservoir may often achieve the dual objectives of regulating an irrigation water supply and providing flood control (Ullum).
United States / Groundwater development includes: test well drilling; testing well and well field design; collection and transport of developed supply (AK-Chin Water Supply; Arizona)

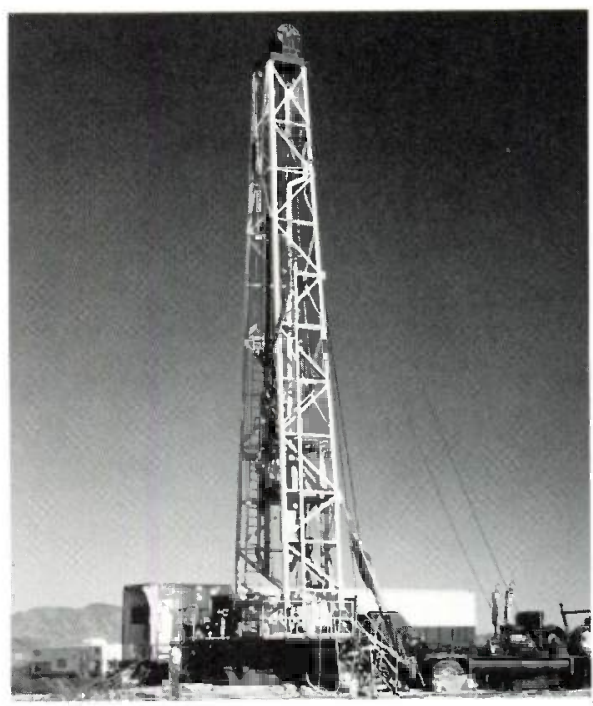




\section{LAND DEVELOPMENT}

\section{REPRESENTATIVE PROJECTS}

\begin{tabular}{|c|c|c|c|c|c|}
\hline Sponsor or Client & Project Name & Location & Description & Harza Services & Date \\
\hline $\begin{array}{l}\text { United States } \\
\text { Benjamin-Kasl \& } \\
\text { Associates (Lake } \\
\text { Andes-Wagner Irrigation } \\
\text { District) }\end{array}$ & Lake Andes-Wagner & South Dakota & $\begin{array}{l}\text { Pumping plants, conveyance } \\
\text { canals, pipe distribution system, } \\
\text { and drains for } 79,000 \text { acre } \\
(32,000 \text { ha) irrigation project. }\end{array}$ & $\begin{array}{l}\text { Feasibility-level planning and } \\
\text { economic analyses. }\end{array}$ & $\begin{array}{l}1976- \\
1977\end{array}$ \\
\hline $\begin{array}{l}\text { Franzoy-Corey and } \\
\text { Associates (Ak-Chin } \\
\text { Indian Community) }\end{array}$ & Ak-Chin Water Supply & Arizona & $\begin{array}{l}\text { Well field and } 30 \text {-mile }(48 \mathrm{~km}) \\
\text { long conveyance system to } \\
\text { deliver } 30,000 \text { ( } 37 \text { million cubic } \\
\text { meter) acre-feet of water for } \\
\text { irrigation. }\end{array}$ & $\begin{array}{l}\text { Planning and environmental } \\
\text { studies. Design of on-reservation } \\
\text { link, including } 8.5 \text {-mile long } \\
\text { siphon." }\end{array}$ & $\begin{array}{l}1980- \\
\text { present }\end{array}$ \\
\hline John W. Klooster & Peat Development Study & Minnesola & $\begin{array}{l}\text { Use of peat as a fuel and feed- } \\
\text { stock in agricultural processing. }\end{array}$ & $\begin{array}{l}\text { Study of the feasibility of using } \\
\text { peat in processing soybeans, } \\
\text { pelletizing grasses and other } \\
\text { applications. }\end{array}$ & 1981 \\
\hline \multirow[t]{3}{*}{$\begin{array}{l}\text { Metropolitan Sanitary } \\
\text { District of Greater } \\
\text { Chicago }\end{array}$} & $\begin{array}{l}\text { Land Reclamation Using } \\
\text { Digested Sewage Sludge }\end{array}$ & Illinois & $\begin{array}{l}\text { Plan to use MSD's entire output of } \\
\text { digested sludge in productive } \\
\text { agriculture. }\end{array}$ & $\begin{array}{l}\text { Socio-economic, environmental, } \\
\text { fertilization value, crop selection, } \\
\text { and operation studies. }\end{array}$ & 1967 \\
\hline & Sludge Utilization Project & Illinois & $\begin{array}{l}\text { Design studies for the } 2000 \text {-acre } \\
\text { ( } 800 \text { ha) first phase sludge } \\
\text { utilization development. }\end{array}$ & $\begin{array}{l}\text { Design of sludge conveyance and } \\
\text { application systems, contract } \\
\text { documents for first year } \\
\text { construction and subsequent } \\
\text { expansion. }\end{array}$ & 1978 \\
\hline & $\begin{array}{l}\text { Hanover Park Sludge } \\
\text { Utilization }\end{array}$ & Illinois & $\begin{array}{l}\text { A } 200 \text {-acre ( } 80 \text { ha) project with } \\
\text { gated pipe distribution, terraced } \\
\text { land with tile drains and recycling } \\
\text { pumps. }\end{array}$ & $\begin{array}{l}\text { Planning, design, and contract } \\
\text { documents, including engineering, } \\
\text { agricultural, and environmental } \\
\text { aspects. }\end{array}$ & 1976 \\
\hline $\begin{array}{l}\text { Various farm owners } \\
\text { and management } \\
\text { organizations }\end{array}$ & $\begin{array}{l}\text { Farm Land Development } \\
\text { and Soil Conservation }\end{array}$ & lowa and Illinois & $\begin{array}{l}\text { Use of bench terraces and drains } \\
\text { for erosion control and rainfall } \\
\text { infiltration of } 3000 \text { acres ( } 1200 \\
\text { ha). }\end{array}$ & $\begin{array}{l}\text { Topographic mapping, layout and } \\
\text { design, and benefil/cost studies. }\end{array}$ & $\begin{array}{l}1965- \\
1970\end{array}$ \\
\hline $\begin{array}{l}\text { Argentina } \\
\text { Agua y Energia } \\
\text { Electrica }\end{array}$ & Rio Dulce & Santiago del Estero & $\begin{array}{l}\text { Reciamation of saline soils and } \\
\text { irrigation of } 118,000 \text { hectares. }\end{array}$ & $\begin{array}{l}\text { Hydrologic studies, soil surveys, } \\
\text { layout of drainage and irrigation } \\
\text { systems, and preliminary } \\
\text { designs." }\end{array}$ & $\begin{array}{l}1964- \\
1965\end{array}$ \\
\hline $\begin{array}{l}\text { Comision Nacional de } \\
\text { la Cuenca del Plata }\end{array}$ & Zanja del Tigre & Rio Bermejo & $\begin{array}{l}66 \text { meler high water supply dam, } \\
\text { downstream diversion dam, and } \\
100,000 \text { hectare irrigation system. }\end{array}$ & $\begin{array}{l}\text { Feasibility studies of the main dam } \\
\text { and appraisal of the irrigation } \\
\text { project." }\end{array}$ & 1974 \\
\hline Provincia de San Juan & Ullum Valley & Tulum Valley & $\begin{array}{l}\text { Irrigation of } 100,000 \text { hectares, } \\
66-\text { meter high water supply dam, } \\
40-\mathrm{MW} \text { powerhouse. }\end{array}$ & $\begin{array}{l}\text { Irrigation planning, design and } \\
\text { assistance during construction of } \\
\text { dam, and subsurface drainage } \\
\text { and erosion control planning. }\end{array}$ & $\begin{array}{l}1969- \\
\text { present }\end{array}$ \\
\hline \multicolumn{6}{|l|}{$\begin{array}{l}\text { Argentina- } \\
\text { Paraguay }\end{array}$} \\
\hline $\begin{array}{l}\text { Comision Mixta Tecnica } \\
\text { Paraguayo-Argentina }\end{array}$ & $\begin{array}{l}\text { Yacyreta and } \\
\text { Corpus Multi- } \\
\text { Purpose Projects }\end{array}$ & Parana River & $\begin{array}{l}\text { Potential irrigation of } 90,000 \\
\text { ha downsteam of Yacyreta } \\
\text { Project and } 140,000 \text { ha down- } \\
\text { stream of Corpus. }\end{array}$ & $\begin{array}{l}\text { Land classification, water supply } \\
\text { studies, and technical and } \\
\text { economic analyses of irrigation } \\
\text { work." }\end{array}$ & $\begin{array}{l}1972 \\
\text { and } \\
1975\end{array}$ \\
\hline $\begin{array}{l}\text { Bangladesh } \\
\text { Bangladesh Water } \\
\text { Development Board, } \\
\text { Asian Development } \\
\text { Bank }\end{array}$ & $\begin{array}{l}\text { Small-Scale Irrigation } \\
\text { Sector Project }\end{array}$ & Bangladesh & $\begin{array}{l}30 \text { small irrigation, drainage, or } \\
\text { flood control projects covering } \\
100,00 \text { hectares. }\end{array}$ & $\begin{array}{l}\text { Screening to identify } 30 \text { projects } \\
\text { followed by feasibility studies on } \\
\text { six projects planned for early } \\
\text { construction. }\end{array}$ & 1981 \\
\hline $\begin{array}{l}\text { Bolivia } \\
\text { Empresa Nacional de } \\
\text { Electricidad }\end{array}$ & San Jacinto Irrigation & Bolivia & $\begin{array}{l}\text { Reservoir, pumping plants, } 5,000- \\
\text { ha irrigation system, and hydro } \\
\text { station. }\end{array}$ & $\begin{array}{l}\text { Alternative project layouts, cost } \\
\text { estimates, determination of } \\
\text { present and projected crop } \\
\text { values." }\end{array}$ & 1970 \\
\hline $\begin{array}{l}\text { Canada } \\
\text { Department of Forestry } \\
\text { and Rural Development }\end{array}$ & $\begin{array}{l}\text { Soil Erosion Control } \\
\text { Program }\end{array}$ & $\begin{array}{l}\text { Allantic } \\
\text { Provinces }\end{array}$ & $\begin{array}{l}\text { Erosion control and increased } \\
\text { productivity through construction } \\
\text { of bench terraces and tile outlets. }\end{array}$ & $\begin{array}{l}\text { Evaluation of erosion, establish } \\
\text { hydrologic and design criteria, and } \\
\text { train local personnel in } \\
\text { implementation. }\end{array}$ & $\begin{array}{l}1967- \\
1968\end{array}$ \\
\hline $\begin{array}{l}\text { Colombia } \\
\text { Instituto Colombiano de } \\
\text { Energia Electrica }\end{array}$ & Betania & Magdalena River & $\begin{array}{l}\text { Comparison of loss of agricultural } \\
\text { production in reservoir area and } \\
\text { development of } 25,000 \text {-ha } \\
\text { project. }\end{array}$ & $\begin{array}{l}\text { Feasibility-level studies of loss of } \\
10,200 \text {-ha reservoir area and } \\
\text { irrigation of new areas." }\end{array}$ & 1972 \\
\hline
\end{tabular}


LAND DEVELOPMENT

\section{REPRESENTATIVE PROJECTS (Cont'd)}

\begin{tabular}{|c|c|c|c|c|c|}
\hline Sponsor or Client & Project Name & Location & Description & Harza Services & Date \\
\hline $\begin{array}{l}\text { Dominlcan } \\
\text { Republic } \\
\text { Instituto Nacional de } \\
\text { Recursos Hidraulicos }\end{array}$ & Sanate & $\begin{array}{l}\text { Sanate and } \\
\text { Yama Rivers }\end{array}$ & $\begin{array}{l}\text { Water supply reservoir on the Sa- } \\
\text { nate River and conveyance canal } \\
\text { to } 5000 \text {-ha project on the Yuma } \\
\text { River. }\end{array}$ & $\begin{array}{l}\text { Planning, design, and contract } \\
\text { plans and specifications. }\end{array}$ & $\begin{array}{l}1974- \\
1975\end{array}$ \\
\hline $\begin{array}{l}\text { Ecuador } \\
\text { Junta Nacional de } \\
\text { Planificacion y } \\
\text { Coodinacion } \\
\text { Economica } \\
\end{array}$ & Pisayambo & Central Ecuador & $\begin{array}{l}\text { Dam, conveyance tunnel and ca- } \\
\text { nals, irrigation of } 21,000 \text { ha, and } \\
\text { two hydro stations totaling } 140 \\
\text { MW. }\end{array}$ & $\begin{array}{l}\text { Power and agriculture market sur- } \\
\text { veys, soil classification, cropping } \\
\text { and water requirements, } \\
\text { preliminary design." } \\
\end{array}$ & $\begin{array}{l}1964- \\
1966\end{array}$ \\
\hline $\begin{array}{l}\text { El Salvador } \\
\text { Ministerio de Agricultura } \\
\text { y Ganaderia }\end{array}$ & $\begin{array}{l}\text { Olomega, Zapotitan, and } \\
\text { Rio Grande de San Miguel } \\
\text { Projects } \\
\text { Soil Erosion Control }\end{array}$ & $\begin{array}{l}\text { El Salvador } \\
\text { Rio Grande de San Miguel } \\
\text { basin }\end{array}$ & $\begin{array}{l}\text { Olomega, } 11,000 \text { ha; Zapotitan, } \\
5000 \text { ha; Rio Grande de San } \\
\text { Miguel, } 31,000 \text { ha. } \\
\text { Appraisal and design of erosion } \\
\text { control measures for } 28,500 \text { ha in } \\
\text { upland areas. }\end{array}$ & $\begin{array}{l}\text { Feasibility-level studies." } \\
\text { Determination of cause and extent of } \\
\text { erosion, recommendations and } \\
\text { design of bench terraces for } 7200 \\
\text { ha." }\end{array}$ & $\begin{array}{l}1965- \\
1967 \\
1967\end{array}$ \\
\hline $\begin{array}{l}\text { Ethiopia } \\
\text { Ministry of Public Works } \\
\text { and Communications }\end{array}$ & Finchaa & Ethiopia & $\begin{array}{l}\text { Drainage of } 31,000 \text { ha Chomen } \\
\text { swamp area and ifrigation of } \\
15,000 \text { ha in the Finchaa Valley. }\end{array}$ & $\begin{array}{l}\text { Appraisal of Finchaa irrigation and } \\
\text { recommendations for development } \\
\text { of Chomen swamp. }\end{array}$ & $\begin{array}{l}1964- \\
1965\end{array}$ \\
\hline $\begin{array}{l}\text { Guinea } \\
\text { Government of Guinea, } \\
\text { U.S. AID, UNDP }\end{array}$ & Riceland Reclamation & Four coastal areas & $\begin{array}{l}\text { Drains and tide-control structures } \\
\text { to reclaim total of } 18,500 \text { ha of } \\
\text { existing cropped area and } \\
1,600 \text { ha of new lands. } \\
\end{array}$ & $\begin{array}{l}\text { Reclamation design and } \\
\text { implementation, soil surveys of } \\
380,000 \text { ha agri-economic } \\
\text { studies of } 42,000 \text { ha. } \\
\end{array}$ & $\begin{array}{l}1963- \\
1972\end{array}$ \\
\hline $\begin{array}{l}\text { Guyana } \\
\text { Ministry of Agriculture }\end{array}$ & $\begin{array}{l}\text { Black Bush and } \\
\text { Tapakuma }\end{array}$ & Coastal areas & $\begin{array}{l}\text { Improvement of irrigation for } \\
40,000 \text { ha of reclaimed land and } \\
\text { expansion by } 23,000 \text { ha. }\end{array}$ & $\begin{array}{l}\text { Evaluation of improvements need- } \\
\text { ed to increase rice production, } \\
\text { water supply and drainage, and } \\
\text { agronomic studies. } \\
\end{array}$ & $\begin{array}{l}1971- \\
1973 \& \\
1976 \\
1977 \\
\end{array}$ \\
\hline $\begin{array}{l}\text { Honduras } \\
\text { Ministry of Natural } \\
\text { Resources }\end{array}$ & Quimistan Valley & Honduras & $\begin{array}{l}\text { 3500-ha project made up of three } \\
\text { gravity-fed irrigation systems } \\
\text { serving } 10 \text {-ha farm units. }\end{array}$ & $\begin{array}{l}\text { Feasibility studies and design, in- } \\
\text { cluding soils and land classifica- } \\
\text { tion, water supply, and } \\
\text { agronomy. }\end{array}$ & $\begin{array}{l}1976- \\
1980\end{array}$ \\
\hline $\begin{array}{l}\text { Indonesia } \\
\text { Directorate General for } \\
\text { Water Resources } \\
\text { Development } \\
\end{array}$ & $\begin{array}{l}\text { Rehabilitation of Irrigation } \\
\text { Systems }\end{array}$ & $\begin{array}{l}\text { Java, Sumatra, and } \\
\text { Sulawesi }\end{array}$ & $\begin{array}{l}\text { Rehabilitation of eight irrigation } \\
\text { systems ranging from } 40 \text { to } 100 \\
\text { years old. }\end{array}$ & $\begin{array}{l}\text { Feasibility studies for } 654,000 \text { ha } \\
\text { and design and implementation for } \\
442,000 \text { ha. }\end{array}$ & $\begin{array}{l}1969- \\
1976\end{array}$ \\
\hline $\begin{array}{l}\text { Iran } \\
\text { Khuzestan Water and } \\
\text { Power Authority }\end{array}$ & $\begin{array}{l}\text { Behbehan } \\
\text { Gotvand }\end{array}$ & $\begin{array}{l}\text { Marun River } \\
\text { Karun River }\end{array}$ & $\begin{array}{l}\text { Water supply dam and down- } \\
\text { stream irrigation of } 55,500 \mathrm{ha} \text {. } \\
\text { Diversion dam and } 40,000 \mathrm{ha} \\
\text { irrigation system including } 300 \mathrm{~km} \\
\text { of primary canals and laterals and } \\
200 \mathrm{~km} \text { of surface drains. } \\
\end{array}$ & $\begin{array}{l}\text { Appraisal, feasibility, and design } \\
\text { services. } \\
\text { Appraisal, feasibility studies, } \\
\text { design, conlract documents, and } \\
\text { construction services." }\end{array}$ & $\begin{array}{l}1966 \\
1979 \\
1967- \\
1979\end{array}$ \\
\hline $\begin{array}{l}\text { Jamaica } \\
\text { Government of } \\
\text { Jamaica, Ministry of } \\
\text { Finance }\end{array}$ & Black River Upper Morass & Black River & $\begin{array}{l}\text { Drains and pumping stations for } \\
4800 \mathrm{ha} \text {, and diversion dam and } \\
\text { irrigation works for } 2400 \mathrm{ha} \text {. }\end{array}$ & $\begin{array}{l}\text { Feasibility and environmental } \\
\text { studies followed by project design } \\
\text { and assistance during } \\
\text { construction." }\end{array}$ & $\begin{array}{l}1976- \\
1982\end{array}$ \\
\hline $\begin{array}{l}\text { Jordan } \\
\text { Jordan Valley Authority }\end{array}$ & $\begin{array}{l}\text { Yarmouk-Jordan Valley } \\
\text { Automated Control } \\
\text { System } \\
\text { Drainage Engineering } \\
\text { Services } \\
\text { King Talal Dam }\end{array}$ & $\begin{array}{l}\text { Jordan Valley } \\
\text { Jordan Valley } \\
\text { Jordan Valley } \\
\text { Zarqua River }\end{array}$ & $\begin{array}{l}\text { Stage I project, including } 70-\mathrm{km} \\
\text { long main canal and disisibutition } \\
\text { canals and drains for } 11,000 \text { ha. } \\
\text { Stage II project, including Maqarin } \\
\text { water supply dam and } \\
\text { powerhouse, and piped distribution } \\
\text { to } 36,000 \text { ha. } \\
\text { Computer-based control system to } \\
\text { monitor crop conditions and } \\
\text { allocate waler throughout } 36,000 \\
\text { ha project area. } \\
\text { Subsurface draining and salinity } \\
\text { control of } 36,000 \text { ha. } \\
\\
\text { Raising } 100 \text {-m high dam by } 16 \mathrm{~m} \\
\text { to irrigate } 2,200 \text { ha of new lands } \\
\text { and maintaih in production } 2,400 \\
\text { ha of currently irrigated land; add } 4 \\
\text { Mw hydropower facilities. }\end{array}$ & $\begin{array}{l}\text { Master planning, feasibility, de- } \\
\text { sign, contract documents, construc- } \\
\text { tion services, and initial operation. } \\
\text { Detailed planning and design with } \\
\text { market and economic studies, } \\
\text { soils survey, and plan } \\
\text { optimization. } \\
\text { Design and preparation of contract } \\
\text { documents for system hardware } \\
\text { and software. } \\
\text { Assistance in planning, soil and } \\
\text { water table investigations, design, } \\
\text { construction, operation and } \\
\text { maintenance of surface and } \\
\text { subsurface drainage systems. } \\
\text { Feasibility studies, including eco- } \\
\text { nomic appraisal of high value } \\
\text { export crops to increase foreign } \\
\text { exchange earnings and farmer } \\
\text { settlement plans; design; contract } \\
\text { documents:construction services. }\end{array}$ & $\begin{array}{l}1955- \\
1963 \\
1976- \\
\text { present } \\
1980- \\
\text { present } \\
\\
1978- \\
1982 \\
\\
1981 \\
\text { present }\end{array}$ \\
\hline $\begin{array}{l}\text { Nicaragua } \\
\text { Instituto de Fomento } \\
\text { Nacional }\end{array}$ & Rivas Irrigation & Lake Nicaragua & $\begin{array}{l}\text { 9000-ha irrigation system with two } \\
\text { pumping stations, } 4-\mathrm{km} \\
\text { conveyance canal, and laterals and } \\
\text { drains. }\end{array}$ & $\begin{array}{l}\text { Review of planning, preparation of } \\
\text { design drawings and } \\
\text { specifications, and training of } \\
\text { engineers. }\end{array}$ & $\begin{array}{l}1963- \\
1964\end{array}$ \\
\hline
\end{tabular}




\section{LAND DEVELOPMENT}

\section{REPRESENTATIVE PROJECTS (Cont'd)}

\begin{tabular}{|c|c|c|c|c|c|}
\hline Sponsor or Client & Project Name & Location & Description & Harza Services & Date \\
\hline $\begin{array}{l}\text { Pakistan } \\
\text { Water and Power } \\
\text { Development Authority }\end{array}$ & $\begin{array}{l}\text { Mardan Salinity Control and } \\
\text { Reclamation Project } \\
\text { Water-logging and Salinity } \\
\text { Control }\end{array}$ & $\begin{array}{l}\text { Northwest Pakistan } \\
\text { National }\end{array}$ & $\begin{array}{l}\text { Increase water supply, improve } \\
\text { canal/drainage systems, reclaim } \\
\text { saline land in } 55,000 \text {-ha area; } \\
\text { feasibility study to improve adjacent } \\
116,000 \text {-ha irrigated area. } \\
\text { Technical program to attain } \\
\text { optimum agricultural production. }\end{array}$ & $\begin{array}{l}\text { Assistance with planning, design, } \\
\text { construction surveillance, and } \\
\text { training services." } \\
\text { Specialized consulting and training } \\
\text { services provided by Harza } \\
\text { personnel in Pakistan. }\end{array}$ & $\begin{array}{l}1980- \\
\text { present } \\
1974- \\
1978\end{array}$ \\
\hline $\begin{array}{l}\text { Saudi Arabia } \\
\text { Ministry of Agriculture } \\
\text { and Water }\end{array}$ & $\begin{array}{l}\text { West of Dammam and } \\
\text { Adjacent Areas Agricultural } \\
\text { Drainage } \\
\text { Ghuwayba Agricultural } \\
\text { Drainage }\end{array}$ & $\begin{array}{l}\text { Eastern Province } \\
\text { Eastern Province }\end{array}$ & $\begin{array}{l}\text { 7,000-ha of project areas needing } \\
\text { agricultural drainage selected from } \\
475-\text { square } \mathrm{km} \text { study area. } \\
7,600 \text {-ha of study area with } \\
\text { potential for high water tables. }\end{array}$ & $\begin{array}{l}\text { Soil surveys, land classification, in- } \\
\text { stallation and monitoring of observa- } \\
\text { tion wells and piezometers, } \\
\text { drainage system design, contract } \\
\text { documents. } \\
\text { Soli surveys, land classification, in- } \\
\text { stallation and monitoring of observa- } \\
\text { tion wells and piezometers, } \\
\text { drainage system design, contract } \\
\text { documents. }\end{array}$ & $\begin{array}{l}1982- \\
\text { present } \\
\text { 1982- } \\
\text { present }\end{array}$ \\
\hline $\begin{array}{l}\text { Thailand } \\
\text { Royal Irigation } \\
\text { Department }\end{array}$ & $\begin{array}{l}\text { Nam Mun and Nam Chi } \\
\text { Nam Mun and Nam } \\
\text { See Dams }\end{array}$ & $\begin{array}{l}\text { Mun and Chi Rivers } \\
\text { Mun and See Rivers }\end{array}$ & $\begin{array}{l}\text { Water supply and conveyance for } \\
\text { year-round cropping on } 19,000 \text {-ha } \\
\text { Nam Mun and } 30,000 \text {-ha Nam Chi } \\
\text { areas. } \\
\text { Water for Nam Mun irrigation area } \\
\text { supplied trom two } 26-\mathrm{m} \text { high } \\
\text { earthfill dams. }\end{array}$ & $\begin{array}{l}\text { Feasibility studies, including } \\
\text { hydrology, socioeconomic, land } \\
\text { use, and cost estimates for dams, } \\
\text { fish ponds, and irrigation systems. } \\
\text { Update of feasibility study; update } \\
\text { of land use in service and reservoir } \\
\text { areas; develop resettlement plans; } \\
\text { foundation exploration; design; } \\
\text { contract documents. }\end{array}$ & $\begin{array}{l}1968- \\
1970 \\
\\
1976-77 ; \\
1980-\end{array}$ \\
\hline $\begin{array}{l}\text { Uruguay } \\
\text { Ministry of Public Works }\end{array}$ & $\begin{array}{l}\text { Tacuarembo-Rivera } \\
\text { Regional Development } \\
\text { Zapucay Irrigation }\end{array}$ & $\begin{array}{l}\text { Uruguay } \\
\text { Uruguay }\end{array}$ & $\begin{array}{l}\text { Inventory of development potential, } \\
\text { including needed roads and } \\
\text { railroads, water supply, and } \\
\text { irrigation of } 100,000 \text { ha. } \\
\text { waler supply dam and } 3500 \text {-ha } \\
\text { pilot project to demonstrate } \\
\text { irrigation benefits and techniques. }\end{array}$ & $\begin{array}{l}\text { Appraisal of natural resources, } \\
\text { socio-economic programs, and } \\
\text { recommendation of } 5 \text {-year data } \\
\text { collection project." } \\
\text { Feasibility-level hydrologic, } \\
\text { agronomic, engineering, and } \\
\text { economic studies. " } \\
\end{array}$ & $\begin{array}{l}1961- \\
1963 \\
\\
1961 . \\
1963\end{array}$ \\
\hline
\end{tabular}
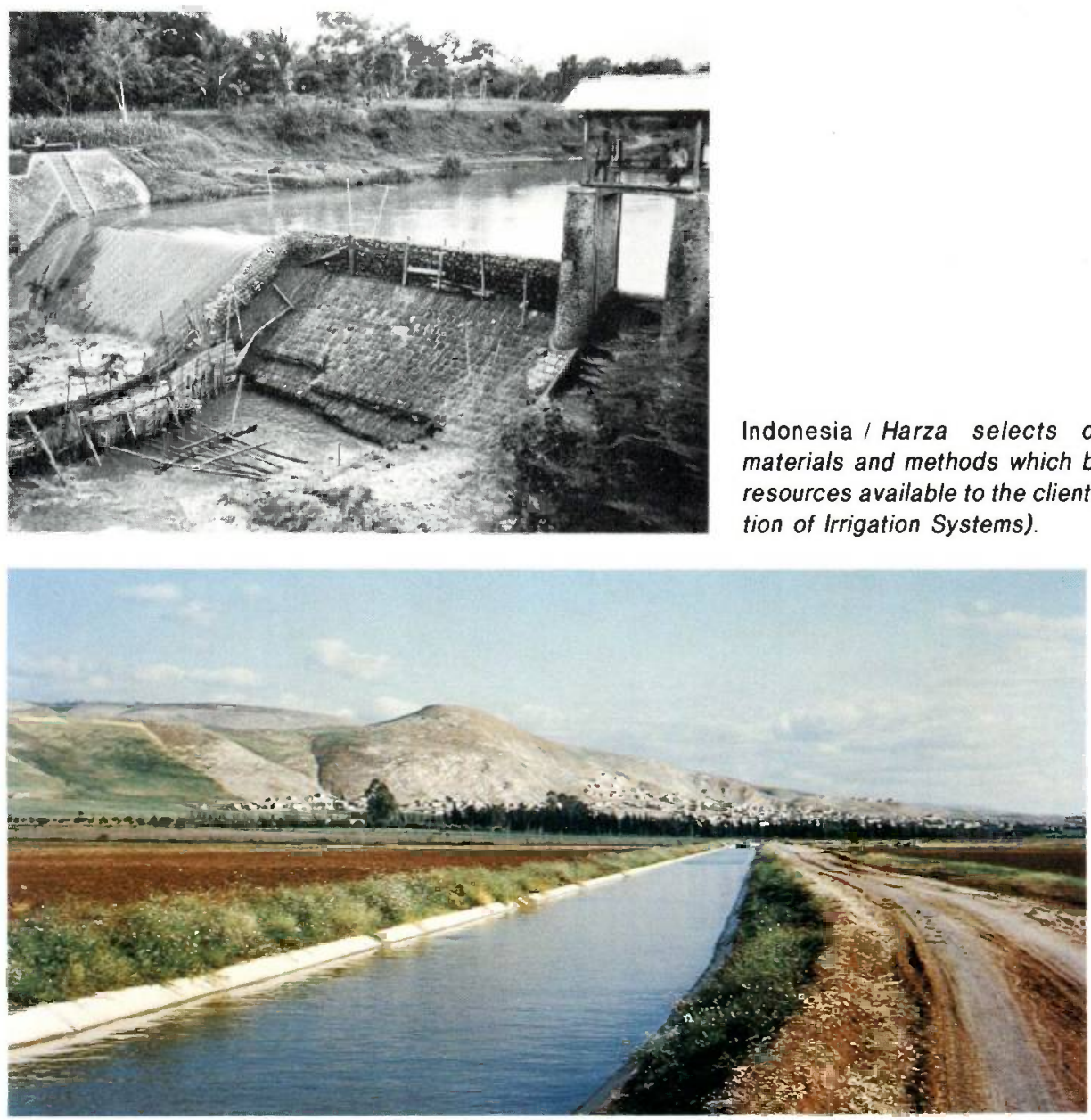

Indonesia / Harza selects construction materials and methods which best use the resources available to the client (Rehabilitation of Irrigation Systems).
Jordan / Staged construction enables revenues from first-stage developments to finance later-stage development. Stage 1 project included $70-\mathrm{km}$ long main canal and distribution drains for 11,000 hectares. (Yarmouk-Jordan Valley). 


\section{INSTITUTIONAL/MANAGEMENT STUDIES}

\section{Management assessments ... water resources and watershed management ... marketing studies ... rural electrification}

hese project descriptions
reflect Harza's depth of experience and talent which have been utilized worldwide to extend our client's own administrative and technical capabilities.

- Harza recommended and organized creation of a National Water Resources Board within the Office of the Prime Minister of Thailand.

- Over 130 Iranian managers, engineers and directors participated in Harza's executive management training programs.

- Study of social, administrative, institutional, labor and legal aspects of Yacyreta-Apipe Project, Argentina.

- Assisted the Jordan Valley Authority, Jordan, in developing the technical and administrative abilities for a new Drainage Division within the Authority.

- Performed institutional analysis of public and private agencies involved in Bolivia's Chaco region development.

In 1979, Harza was awarded a gold medal by Pakistan's Water and Power Development Authority in recognition of meritorious service over a 20 year period.

T oday's successful resources development projects must satisfy the constraints of physical, environmental, economic, financial, institutional and social aspects. Harza works with its clients to identify priorities for new projects. Then we help to determine proper operation and management guidelines. For existing projects, effective management and training improve project performance.

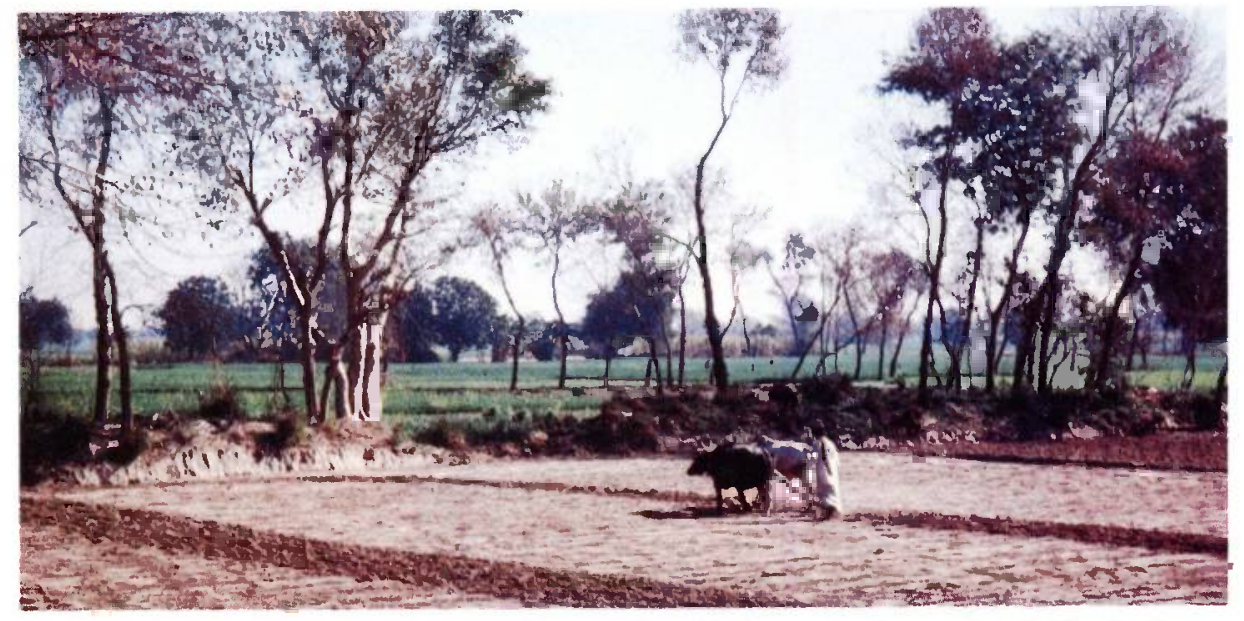

Pakistan / Training in methods of proper land grading aids in more uniform water distribution for improved yields. For the Water and Power Development Authority, Harza provided general consulting and training services related to flood management, waterlogging and salinity control, streamflow and climatology, master planning, and power system development.

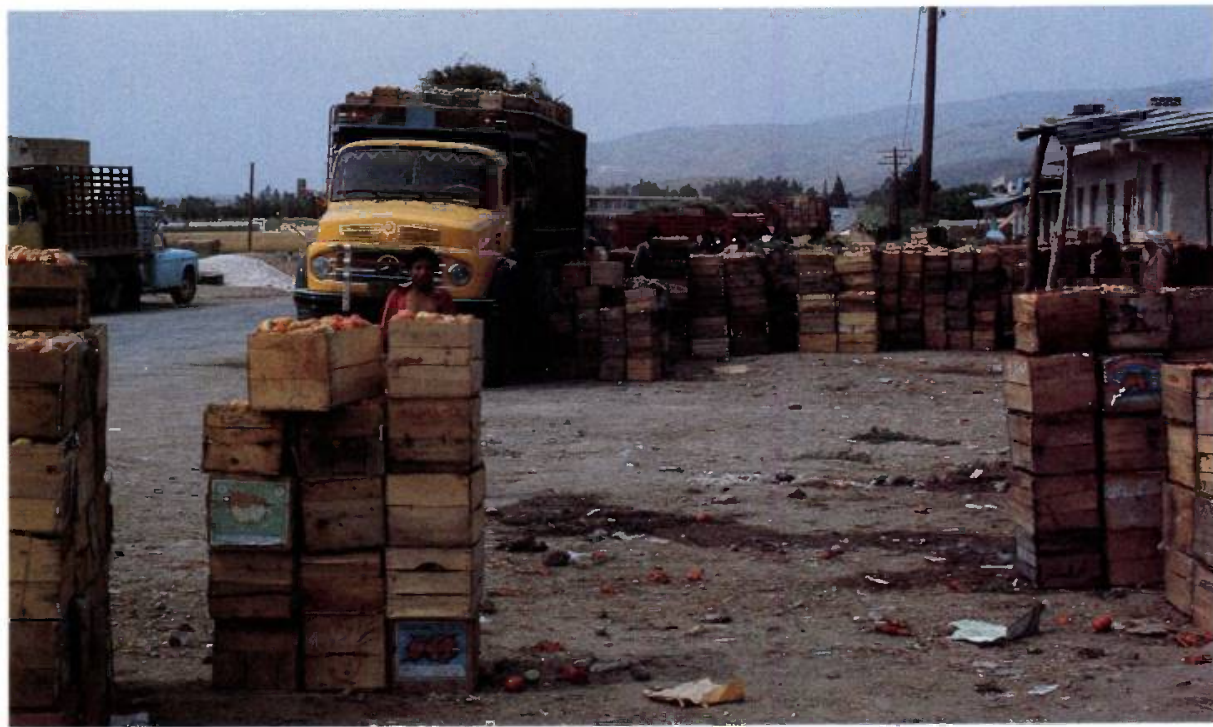

Jordan / Attention to harvesting, processing, transporting and marketing assures that potential benefits from crop production are realized (Marbeten Study).

Thailand / Resource investigation teams combine the talents of client and staffs ( $\mathrm{Nam}$ Mun and Lam Sae Dams)

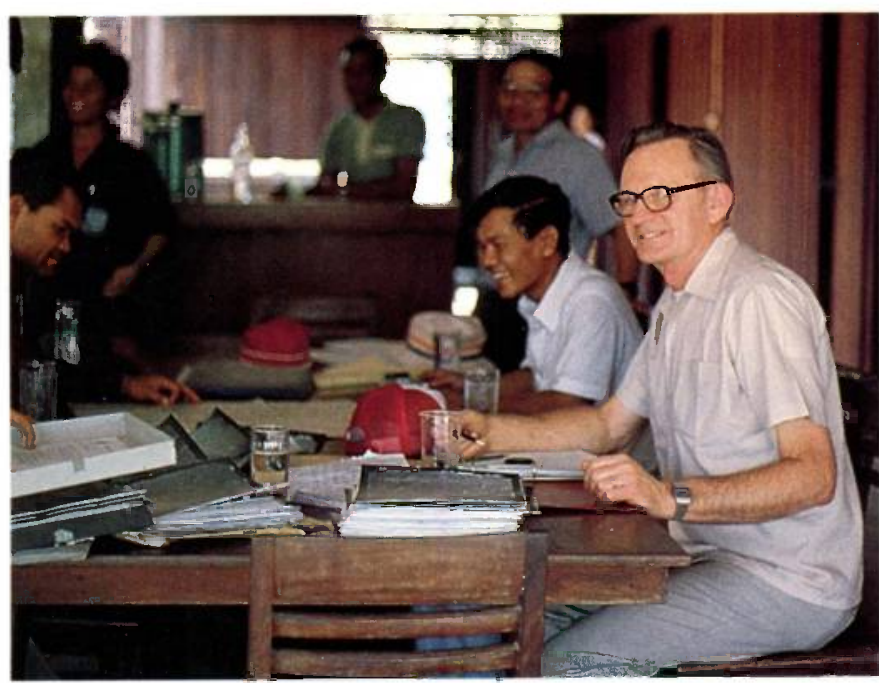




\section{INSTITUTIONAL/MANAGEMENT STUDIES}

Agricultural extension is an important service contributing to the ultimate success of an agricultural development project. Harza is staffed to provide experienced, specialized help and counsel in: seed improvement; cultural practices; farm maintenance programs; economics and marketing; credit and cooperatives; processing and storage; transportation and marketing; and socio-economic studies.

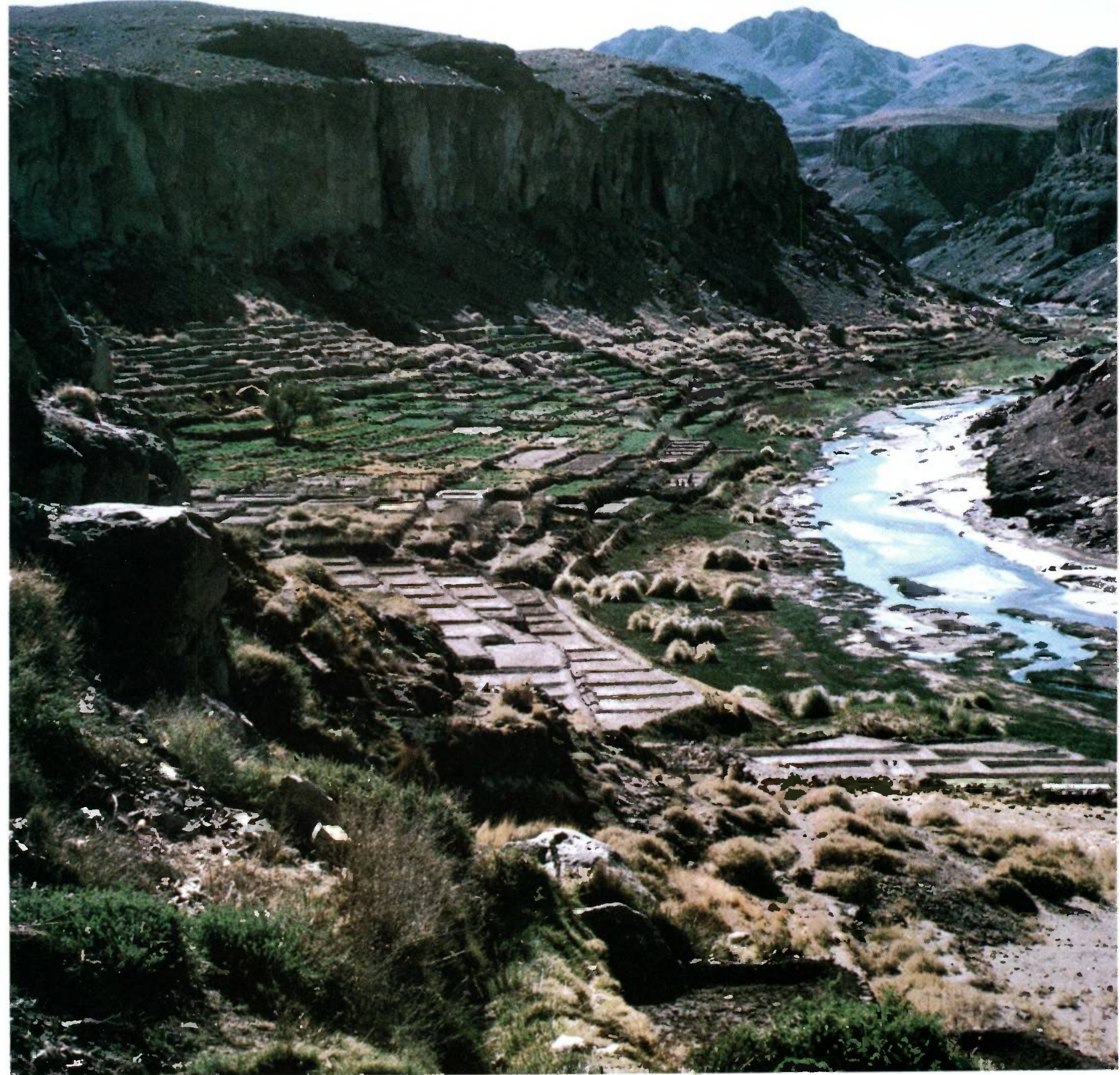




\section{SERVICES}

\section{Assessments of Institutions}

- Evaluation of demands, needs, and objectives

- Inventory of organizations and functional responsibilities

- Evaluation of dissemination of authority and responsibilities

- Formulation of alternative institutional responsibilities

- Recommendations for alternative and proven institutional frameworks

Technical Aids for Management

- Irrigation scheduling

- Soil water movement and storage studies

- Evapotranspiration measurement and prediction

- Irrigation efficiency studies

- Monitoring of changes in resource characteristics

- Computer simulation modeling

- Master planning

- Project planning, design, and contract documents

- Operation and maintenance programs

- Economic and financial analyses

Evaluation of Management Practices

- Consideration of current and future needs

- Analysis of existing management practices and interrelationships

- Development of recommended management practices

\section{Technical Management Training Programs}

These programs are specific to the needs of our clients and are conducted with the cooperation of universities, industry and government agencies throughout the United States and other countries. Specialized management training programs are also offered at Harza's Chicago headquarters.

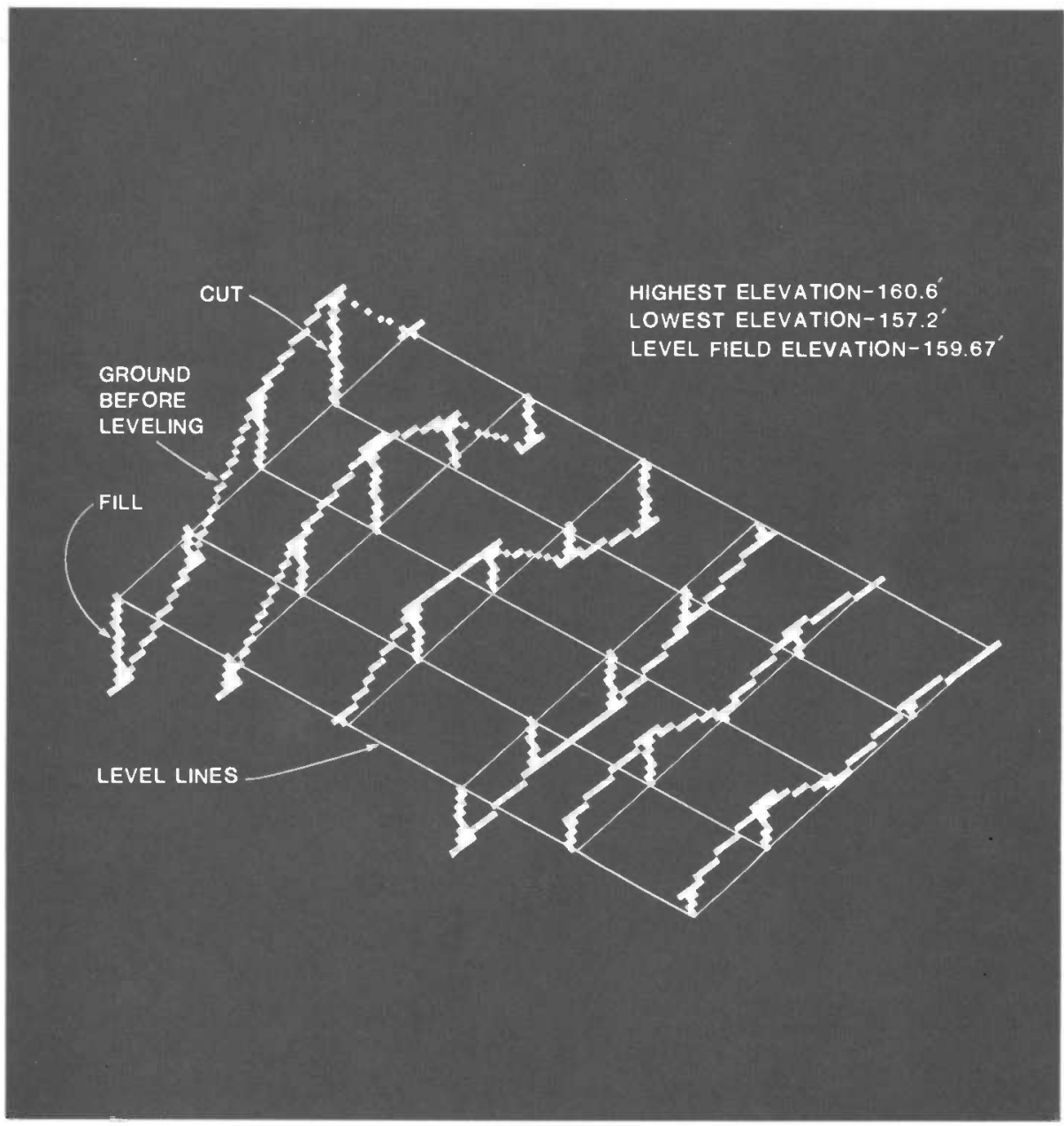

Jamaica / Computer-generated visual aid used to illustrate the minimum movement of soil needed to level a field for irrigation. (Black River Upper Morass). 
INSTITUTIONAL/MANAGEMENT STUDIES

\section{REPRESENTATIVE PROJECTS}

\begin{tabular}{|c|c|c|c|c|c|}
\hline Sponsor or Client & Project Name & Location & Description & Harza Services & Date \\
\hline $\begin{array}{l}\text { United States } \\
\text { Irrigation scheduling- } \\
\text { various farm owners } \\
\text { and operators } \\
\text { U.S. Bureau of } \\
\text { Reclamation }\end{array}$ & $\begin{array}{l}\text { Harza Agricultural } \\
\text { Services } \\
\text { Garrison Environmental } \\
\text { Study }\end{array}$ & $\begin{array}{l}\text { California Central Valley } \\
\text { North Dakota }\end{array}$ & $\begin{array}{l}\text { Scheduled irrigations and depth of } \\
\text { application for specific crops and } \\
\text { fields. } \\
\text { Environmental impacts resulting } \\
\text { from development of the } 250,000 \text { - } \\
\text { ac Garrison Diversion Unit. }\end{array}$ & $\begin{array}{l}\text { Modeled evapotranspiration using } \\
\text { soil, weather and crop develop- } \\
\text { ment data. Consirucled and } \\
\text { operated climatological stations. } \\
\text { Study of effects of irrigation return } \\
\text { flows on water quality and } \\
\text { ecology in } 1400 \text { miles of rivers } \\
\text { and streams. }\end{array}$ & $\begin{array}{l}1974- \\
1978 \\
\\
1975- \\
1976\end{array}$ \\
\hline $\begin{array}{l}\text { Afghanistan } \\
\text { U.S. Agency for } \\
\text { International } \\
\text { Development }\end{array}$ & Rural Electric Survey & $\begin{array}{l}\text { Helmand-Arghandab } \\
\text { Valleys }\end{array}$ & $\begin{array}{l}\text { Development of energy demand } \\
\text { projections for tarm and urban } \\
\text { families in the area. }\end{array}$ & $\begin{array}{l}\text { Surveys of energy use in electri- } \\
\text { fied areas were used to estimate } \\
\text { demand in areas to be electrified. }\end{array}$ & 1976 \\
\hline $\begin{array}{l}\text { Bangladesh } \\
\text { Water Development } \\
\text { Board; World Bank }\end{array}$ & $\begin{array}{l}\text { Organizational } \\
\text { Strengthening }\end{array}$ & Bangladesh & $\begin{array}{l}\text { Development of recommendations } \\
\text { for strengthening organizational } \\
\text { and project implementation } \\
\text { aspects. }\end{array}$ & $\begin{array}{l}\text { Study of organizational, } \\
\text { management, and project } \\
\text { implementation and operation } \\
\text { procedures. }\end{array}$ & $\begin{array}{l}1980- \\
\text { present }\end{array}$ \\
\hline $\begin{array}{l}\text { Bolivia } \\
\text { Ministry of Planning and } \\
\text { Coordination }\end{array}$ & $\begin{array}{l}\text { Chaco Boliviano } \\
\text { Institutional Study }\end{array}$ & Bolivia & $\begin{array}{l}\text { Institutional analysis of public and } \\
\text { private agencies involved in } \\
\text { Chaco region development. }\end{array}$ & $\begin{array}{l}\text { Formulate and recommend } \\
\text { institutional organization plan. }\end{array}$ & $\begin{array}{l}\text { 1981- } \\
\text { present }\end{array}$ \\
\hline $\begin{array}{l}\text { Chile } \\
\text { United Nations } \\
\text { Development Program }\end{array}$ & $\begin{array}{l}\text { Water Resources } \\
\text { Management }\end{array}$ & Norte Grande region & $\begin{array}{l}\text { Plan for conservation of irrigation, } \\
\text { industrial, and domestic waler } \\
\text { supply in extremely arid region. }\end{array}$ & $\begin{array}{l}\text { Development of alternalive water } \\
\text { use plans and use of computer } \\
\text { modeling to analyze results. }\end{array}$ & $\begin{array}{l}1977- \\
1978\end{array}$ \\
\hline $\begin{array}{l}\text { El Salvador } \\
\text { Inter-American } \\
\text { Development Bank }\end{array}$ & Feeder Road Appraisal & El Salvador & $\begin{array}{l}\text { Feeder road development in rural } \\
\text { areas of El Salvador. }\end{array}$ & $\begin{array}{l}\text { Feasibility analysis for financing of } \\
\text { road building program. }\end{array}$ & 1981 \\
\hline $\begin{array}{l}\text { Ghana } \\
\text { Government of Ghana }\end{array}$ & Water Resources Survey & Ghana & $\begin{array}{l}\text { Nation-wide study of water } \\
\text { resources, agriculture, and } \\
\text { transportation needs. }\end{array}$ & $\begin{array}{l}\text { Field surveys, layout of } \\
\text { community water supply systems, } \\
\text { and recommendations for } \\
\text { financing and implementation." } \\
\end{array}$ & $\begin{array}{l}1969- \\
1970\end{array}$ \\
\hline $\begin{array}{l}\text { Honduras } \\
\text { Ministry of Natural } \\
\text { Resources }\end{array}$ & Institutional Assessment & Honduras & $\begin{array}{l}\text { Assessment of institutional needs } \\
\text { in relation to development of Sula } \\
\text { Valley and Quimistan projects. }\end{array}$ & $\begin{array}{l}\text { Recommendations to assure that } \\
\text { farm inputs would be supplied and } \\
\text { utilized effectively. }\end{array}$ & 1980 \\
\hline $\begin{array}{l}\text { Indonesia } \\
\text { Directorate General for } \\
\text { Water Resources } \\
\text { Development }\end{array}$ & $\begin{array}{l}\text { Management Assistance } \\
\text { in Irrigation Rehabilitation }\end{array}$ & Indonesia & $\begin{array}{l}\text { Eight-year program of technical } \\
\text { assistance in rehabilitation of } \\
\text { systems covering } 442,000 \text { ha. }\end{array}$ & $\begin{array}{l}\text { Guidance and counterpart training } \\
\text { of key management, engineering, } \\
\text { and agricultural personnel." }\end{array}$ & $\begin{array}{l}1969- \\
1976\end{array}$ \\
\hline $\begin{array}{l}\text { Iraq } \\
\text { Government of Iraq, } \\
\text { FAO }\end{array}$ & $\begin{array}{l}\text { Kaiseba Design } \\
\text { Assistance }\end{array}$ & Kaiseba, Iraq & $\begin{array}{l}\text { Review and administrative assist- } \\
\text { ance with planning and design of } \\
17,000 \text {-ha irrigation project. }\end{array}$ & $\begin{array}{l}\text { Establishment of economic evalua- } \\
\text { tion, design, and construction } \\
\text { inspection procedures. }\end{array}$ & $\begin{array}{l}1979- \\
1980\end{array}$ \\
\hline $\begin{array}{l}\text { Jamaica } \\
\text { Ministry of Finance }\end{array}$ & $\begin{array}{l}\text { Cropping/Markeling } \\
\text { Analysis }\end{array}$ & $\begin{array}{l}\text { Black River Upper } \\
\text { Morass }\end{array}$ & $\begin{array}{l}\text { Detailed analysis of cropping and } \\
\text { marketing factors for the } 10,000- \\
\text { ha Black River irrigation project. }\end{array}$ & $\begin{array}{l}\text { Selection of suitable crops, eco- } \\
\text { nomic analysis, marketing } \\
\text { potential, and alternative cropping } \\
\text { patterns. }\end{array}$ & $\begin{array}{l}1976- \\
1977\end{array}$ \\
\hline $\begin{array}{l}\text { Jordan } \\
\text { Jordan Valley Authority }\end{array}$ & Marketing Study & Yamouk-Jordan Valley & $\begin{array}{l}\text { Study of market demands, quality } \\
\text { requirements, and pricing for } \\
\text { project crops in local and foreign } \\
\text { markets. }\end{array}$ & $\begin{array}{l}\text { Comprehensive plan to guide crop } \\
\text { selection, cropping patterns, and } \\
\text { infrastructure development. " }\end{array}$ & $\begin{array}{l}1976- \\
1977\end{array}$ \\
\hline $\begin{array}{l}\text { Pakistan } \\
\text { Water and Power } \\
\text { Development Authority } \\
\text { (WAPDA) }\end{array}$ & $\begin{array}{l}\text { General Consulling and } \\
\text { Training Services }\end{array}$ & Pakistan and U.S. & $\begin{array}{l}\text { Flood management, water-logging } \\
\text { and salinity control, streamflow } \\
\text { and climatology, master planning, } \\
\text { and power system development } \\
\text { services. }\end{array}$ & $\begin{array}{l}\text { Guidance and training of WAPDA } \\
\text { management and technical } \\
\text { personnel (and Pakistani } \\
\text { consultants) in on-the-job, } \\
\text { classroom, Harza office, and other } \\
\text { training locations. }\end{array}$ & $\begin{array}{l}1959- \\
1979\end{array}$ \\
\hline $\begin{array}{l}\text { St. Lucia } \\
\text { Amerada Hess } \\
\text { Corporation }\end{array}$ & $\begin{array}{l}\text { St. Lucia Water Supply } \\
\text { Study }\end{array}$ & Roseau River & $\begin{array}{l}\text { Watershed planning with analysis } \\
\text { of alternative dam sites, water } \\
\text { yields and cost of development. }\end{array}$ & $\begin{array}{l}\text { Estimaled the costs of losing } \\
\text { productive land, private property } \\
\text { and infrastructure facilities in the } \\
\text { reservoir area. Investigated } \\
\text { resettlement locations, institutional } \\
\text { aspects and development costs; } \\
\text { engineering, geologic, hydrology } \\
\text { and environmental studies. }\end{array}$ & $\begin{array}{l}1980- \\
1981\end{array}$ \\
\hline $\begin{array}{l}\text { Thailand } \\
\text { National Economic and } \\
\text { Social Development } \\
\text { Board }\end{array}$ & $\begin{array}{l}\text { Organization for Water } \\
\text { Resources Management }\end{array}$ & Thailand & $\begin{array}{l}\text { Management study to clarity } \\
\text { authority and responsibilities of } \\
\text { resources development agencies. }\end{array}$ & $\begin{array}{l}\text { Study of present organization and } \\
\text { recommenations for creation of a } \\
\text { national water resources board to } \\
\text { coordinate all activities. }\end{array}$ & $\begin{array}{l}1977- \\
1978\end{array}$ \\
\hline
\end{tabular}

"Services provided in association with others. 
$\mathrm{H}$ arza's in-house computer capability is based on a Harris $\mathrm{H} 800$ computer and terminals that provide direct access to some of the largest computer systems in the United States. The computer center currently has a library of more than 300 programs for planning and design functions, and the number is constantly growing. The programs most often used for agricultural and multiple-purpose project planning concern:

- Drainage and irrigation flow networks

- Simulation of water table drawdown between drains

- Irrigation water requirements and agricultural production

- Least cost solution for canals and drains

- Project economic analyses

- Reservoir yield and reservoir operation

- Water quality in receiving streams

- Mass balance, water quality in rivers and reservoirs

- Groundwater resources evaluation and aquifer simulation

- Flood hydrographs and backwater profiles

- Flood frequency and flood hazard factors

- Economic impact of fiscal constraints

- Water system constraints

- Economic analysis of power systems $n$ addition to these frequently

used programs, Harza also develops programs to suit the specific needs of clients. In Pakistan, for instance, Harza prepared a program that simulates the operation of that country's extensive irrigation, water suppply, and hydroelectric power systems.

Where needed to achieve
project objectives, computers are installed in field offices for data storage, analysis and word processing functions. For example, in the agricultural drainage projects in Saudi Arabia, Harza is using hardware and

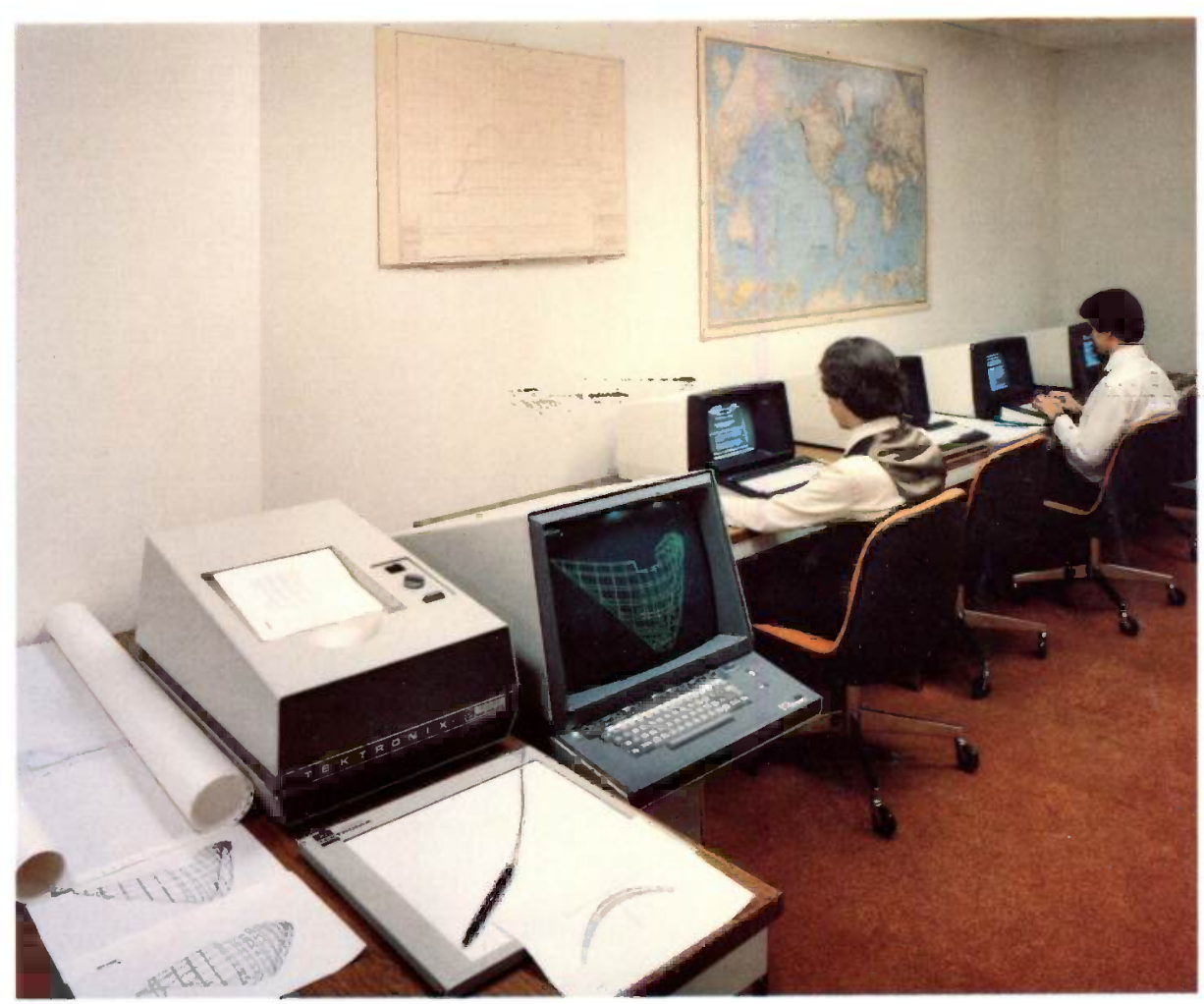

Harza Engineering Company, Chicago / Computer hardware and software systems are regularly improved to assure a balance between the requirements of our clients' projects and the costs of providing computational services. Harza computer specialists can create or adapt programs for the processing of data, or the development of solutions for design projects. 


\section{Impulse}

\begin{tabular}{|c|c|c|c|c|c|c|c|c|c|}
\hline 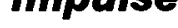 & & & & & & & & & \\
\hline Name of Project & Location & $\begin{array}{c}\text { Year } \\
\text { Initial } \\
\text { Operation }\end{array}$ & Number & $\begin{array}{l}\text { Head } \\
(\mathrm{m})\end{array}$ & Rating & $\begin{array}{l}\text { Speed } \\
(\mathrm{rpm})\end{array}$ & $\begin{array}{l}\text { Generator } \\
\text { Rating } \\
\text { (kVA) }\end{array}$ & $\begin{array}{c}\text { Turbine } \\
\text { Manufacturer }\end{array}$ & $\begin{array}{l}\text { Generator } \\
\text { Manufacturer }\end{array}$ \\
\hline Finchaa & Ethiopia & 1973 & 3 & 550 & 34 & 500 & 35,000 & $\begin{array}{l}\text { Bell } \\
\text { Engineering } \\
\text { Works }\end{array}$ & $\begin{array}{l}\text { NorskElectrisk } \\
\text { \& Brown-Boveri } \\
\text { (NEBB), Norway }\end{array}$ \\
\hline Guatape & Colombia & 1970 & 2 & 804 & 74 & 514 & 77,400 & Escher Wyss & AEG, Germany \\
\hline Las Placetas & $\begin{array}{l}\text { Dominican } \\
\text { Republic }\end{array}$ & $\begin{array}{l}\text { Construction } \\
\text { Deferred }\end{array}$ & 2 & 461 & 45 & 450 & 45,000 & To Be Awarded & To Be Awarded \\
\hline $\begin{array}{l}\text { Río Lindo } \\
\text { Units 3-4 }\end{array}$ & Honduras & 1978 & 2 & 373 & 22 & 450 & 21,053 & Hitachi & Hitachi \\
\hline Units 1-2 & Honduras & 1971 & 2 & 373 & 22 & 450 & 21,053 & Hitachi & Hitachi \\
\hline SanAgatón & Venezuela & 1985 & 2 & 350 & 153 & 225 & 158,000 & EscherWyss & Toshiba \\
\hline
\end{tabular}

\section{Bulb, Fixed-Blade Propeller, and Tube}

\begin{tabular}{|c|c|c|c|c|c|c|c|c|c|}
\hline Name of Project & Location & $\begin{array}{c}\text { Year } \\
\text { Initial } \\
\text { Operation }\end{array}$ & $\begin{array}{c}\text { Number } \\
\text { and } \\
\text { Type }\end{array}$ & $\begin{array}{l}\text { Head } \\
(\mathrm{m})\end{array}$ & $\mathbf{M W}$ & $\begin{array}{l}\text { Speed } \\
(\mathrm{pm})\end{array}$ & $\begin{array}{c}\text { Generator } \\
\text { Rating } \\
\text { (kVA) }\end{array}$ & $\begin{array}{c}\text { Turbine } \\
\text { Manufacturer }\end{array}$ & $\begin{array}{c}\text { Generator } \\
\text { Manutacturer }\end{array}$ \\
\hline Brokopondo & Suriname & 1965 & 6 Fixed-Blade & 41 & 33 & 240 & 27,800 & EscherWyss & $\begin{array}{l}\text { Siemens, } \\
\text { Germany }\end{array}$ \\
\hline Gregory B. Janvis & New York & 1986 & 2 Tube & 15 & 4.5 & 257 & 4,500 & $\begin{array}{l}\text { Dominion } \\
\text { Bridge-Sulzer, } \\
\text { Canada }\end{array}$ & Siemens-Allis \\
\hline Hadley Falls & Massachusetts & 1983 & 1Fixed-Blade & 15 & 15.5 & 150 & 15,800 & Allis-Chaimers & Siemens-Allis \\
\hline Main Canal Headworks & Washington & 1985 & 1 Bulb & 13 & 27 & 112 & 25,700 & Fuji Electric & Fujf Electric \\
\hline Santee-Cooper & South Carolina & 1942 & 2Fixed-Blade & 21 & 30 & 120 & 34,000 & Newport News & GE, USA \\
\hline
\end{tabular}

\section{Pumped-Storage Reversible Units}

\begin{tabular}{|c|c|c|c|c|c|c|c|c|c|}
\hline Name of Project & Location & $\begin{array}{c}\text { Year } \\
\text { Inittial } \\
\text { Operation }\end{array}$ & $\begin{array}{l}\text { Number } \\
\text { and } \\
\text { Type }\end{array}$ & $\begin{array}{l}\text { Head } \\
\text { (m) }\end{array}$ & MW & $\begin{array}{l}\text { Speed } \\
(\mathrm{rpm})\end{array}$ & $\begin{array}{l}\text { Generator } \\
\text { Rating } \\
\text { (kVA) }\end{array}$ & $\begin{array}{c}\text { Turbine } \\
\text { Manufacturer }\end{array}$ & $\begin{array}{c}\text { Generator } \\
\text { Manufacturer }\end{array}$ \\
\hline Bath County & Virginia & 1986 & 6Francis & 329 & 380 & 257 & 389,000 & Allis-Chalmers & Siemens-Allis \\
\hline Kinzua/Seneca & Pennsylvania & 1969 & 2Francis & 197 & 156 & 225 & 220,000 & $\begin{array}{l}\text { Newport News, } \\
\text { SD\&D }\end{array}$ & Westinghouse \\
\hline Smith Mountain & Virginia & 1979 & 1 Francis & 37 & 102 & 90 & 135,700 & Allis-Chalmers & Allis-Chalmers \\
\hline
\end{tabular}




\section{The Harza Companies}

Projects that protect and improve the environment

HARZA Engineering Company

150 South Wacker Drive

Chicago, Illinois 60606-4288

(312) $855-7000$

Cable:HARZENG CHICAGO

Telex 25-3540

\section{Subsidiaries}

Stetson-Harza, Inc.

185 Genesee Street

Utica, New York 13501

(315) $797-5800$

Stetson-Harza, Inc.

250 Jordan Road

Troy, New York 12180

(518) 283-8080

Harza Environmental Services, Inc. 150 South Wacker Drive

Chicago, Illinois 60606-4288

(312) 855-3300
Regional Otfices

Alaska: 900 West 5 th Avenue Anchorage, Alaska 99501 (907) 279-0471

Arizona: 5025 East Washington Street Suite 120

Phoenix, Arizona 85034

(602) 244-0992

Colorado: 7979 East Tufts Avenue Parkway, Suite 303

Denver, Colorado 80237

(303) $779-4830$

District of Columbia: 1060 Leigh Mill Road Great Falls, Virginia 22066

(703) $759-6746$

Minnesota: 6760 Old Sturbridge Drive Hamel, Minnesota 55340 (612) 478-9582

Washington: 31919 First Avenue South Suite 100

Federal Way, Washington 98003 (206) 946-515

\section{Worldwide}

Harza Engineering Company:

Algiers, Algeria

San Juan de la Maguana, Dominican Republic

Alexandria, Cairo, Egypt

New Delhi, India; Djakarta, Indonesia

Bakel, Senegal; Khartoum, Sudan

Harza Engineering Company International:

Dhaka, Bangladesh; Giza, Egypt

Madras, India; Abidjan, Ivory Coast

Amman, Jordan; Nairobi, Kenya

Lahore, Peshawar, Rawalpindi, Pakistan

Dammam, Riyadh, Saudi Arabia

Caracas, Puerto Ordaz, Venezuela

Harza Engineering Company International, S.A.:

Buenos Aires, Ituzaingó, Argentina

Santiago, Santo Domingo, Dominican Republic

Quito, Ecuador; San Salvador, El Salvador

Guatemala City, Guatemala

Asunción, Ayolas, Paraguay

Harza Canada, Inc.

Toronto, Ontario, Canada
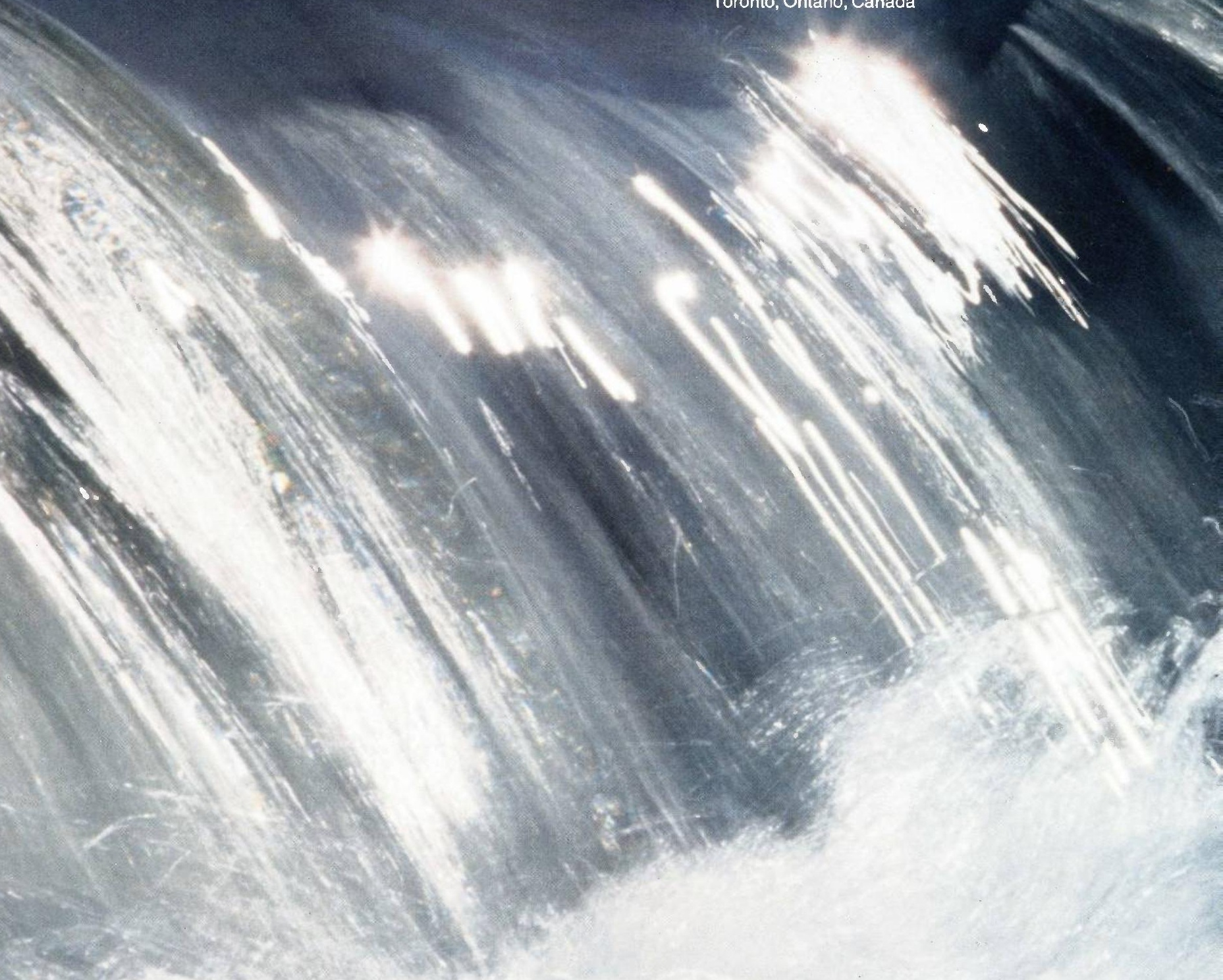


\title{
WORLDWIDE PROJECT DEVELOPMENT SERVICES FOR WATER, LAND AND ENERGY
}

\author{
Water \\ Dams, Dikes, Control Structures \\ Regional and River Basin Planning \\ Water Quality Management \\ Flood Control and Drainage \\ Water Supply and Treatment \\ Wastewater Collection and Treatment \\ Land \\ Irrigation and Drainage \\ Land Reclamation \\ Soil Conservation and Erosion Control \\ Agricultural Economics \\ Tunnels and Underground Structures \\ Transportation \\ Residuals Management
}

\section{Energy}

Hydroelectric, Pumped-Storage, Combustion Turbines

Transmission, Distribution, Substations

Thermal Plant Cooling Systems

Electric System Management

Energy and Mineral Resources

Harza provides complete construction management

and environmental services for projects anywhere in the world.

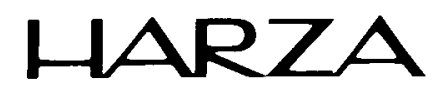

Engineering Company

Consulting Engineers

150 South Wacker Drive

Chicago, Illinois 60606-4176

(312) 855-7000 Cable: HARZENG CHICAGO Telex: 25-3540 


\section{THE HARZA COMPANIES}

Harza Engineering Company and associated companies for worldwide consulting services

Harza Engineering Company Consulting Engineers 150 South Wacker Drive, Chicago, Illinois 60606-4176 (312) 855-7000 Cable: HARZENG CHICAGO Telex 25-3540

\section{United States}

Branch offices:

Alaska: 203 West 15th Avenue, Suite 204, Anchorage, Alaska 99501 (907) 278-4415

Arizona: 1005 East Guadalupe Road, Suite Three, Tempe, Arizona 85283 (602) 831-2513

Colorado: 7108 South Alton Way, Building G, Englewood, Colorado 80112 (303) 779-4830

Washington, D.C.. 1629 K Street N.W., Suite 801, Washington, D.C. 20006 (202) 659-8833

Project offices:

Littleton, Colorado; Hammond, Indiana; Warm Springs, Virginia;

Bellevue, Washington; Pasco, Washington

\section{Overseas}

Harza Engineering Company International: Cairo, Egypt; Giza, Egypt;

Dhaka, Bangladesh; Amman, Jordan; Lahore, Pakistan; Peshawar, Pakistan;

Damman, Saudi Arabia; Riyadh, Saudi Arabia; Ziguinchor, Senegal

Harza Engineering Company International, S.A.: Buenos Aires, Argentina; Santiago, Chile;

Santo Domingo, Dominican Republic; San Salvador, El Salvador; Guatemala City, Guatemala; La Ceiba, Honduras; Asuncion, Paraguay; Lima, Peru (branch office)

Harza de Venezuela, C.A.: Caracas, Venezuela; Puerto Ordaz, Venezuela;

Uribante-Doradas, Tachira State, Venezuela

Harza Canada, Inc.: Halifax, Nova Scotia 


\section{Current Assignments Under TECAID}

- Hydraulic Analysis of the Water System in the Greater Amman Area, Jordan

- Raising Kafraim Dam, Jordan

- Review of La Fortuna Hydroelectric Project, Panama

- Ocho Rios Cruise Ship Study, Jamaica

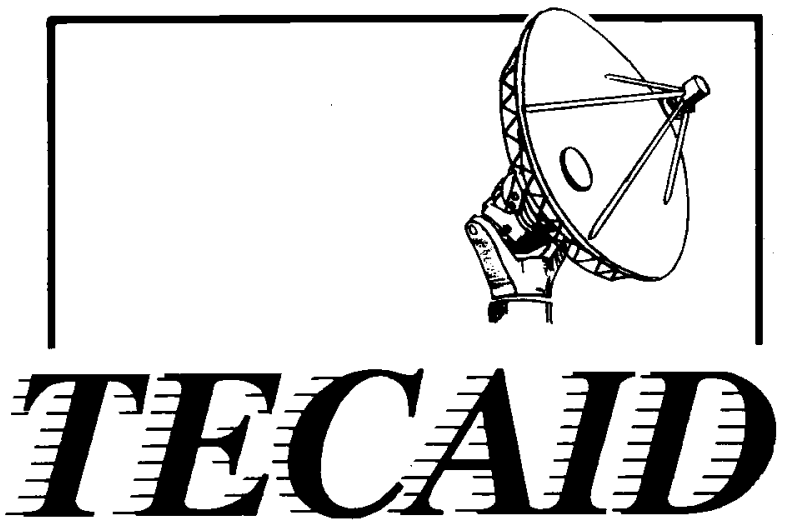

WORLDWIDE TECHNICAL SERVICES THROUGH USAID

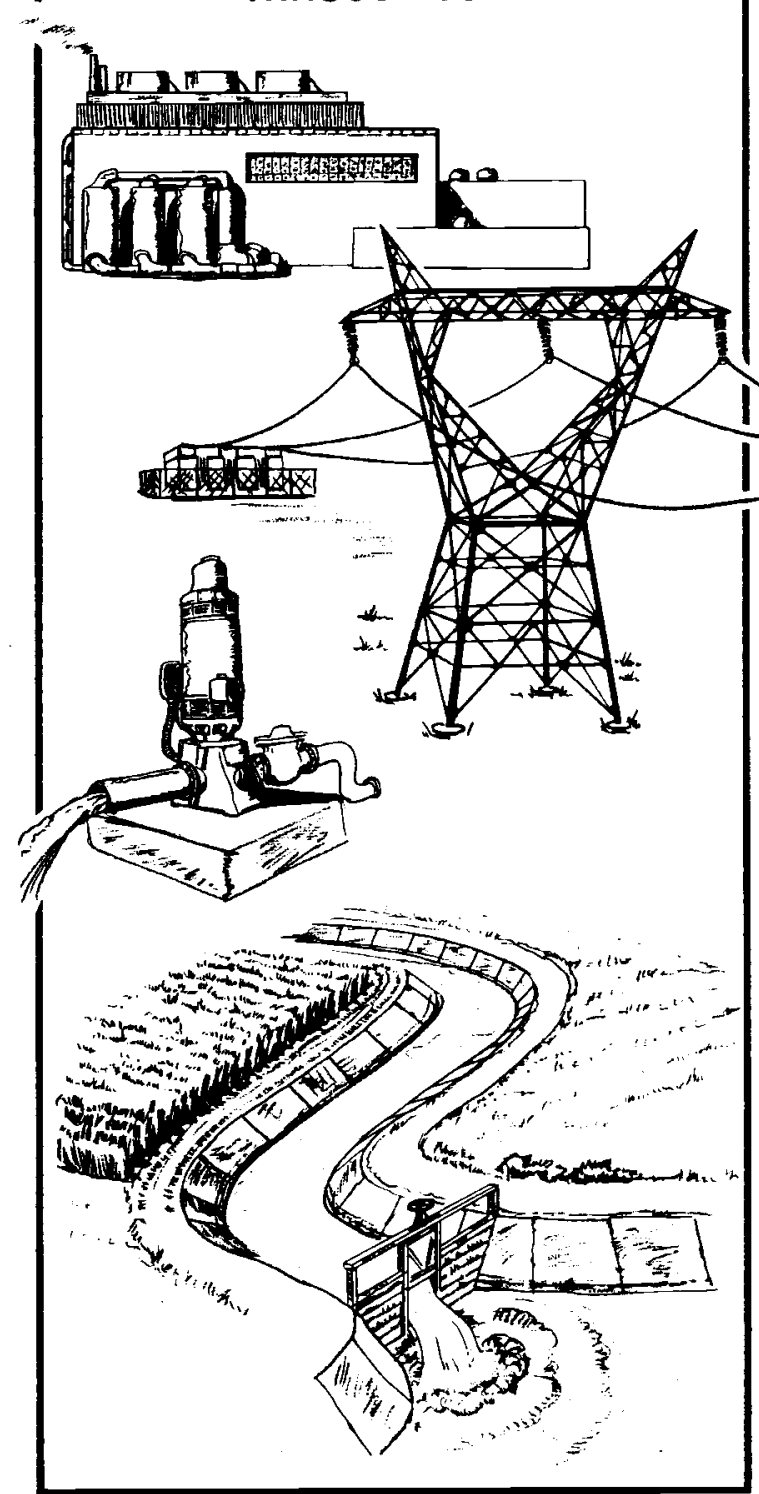


Hydroelectric

Power Plants

\section{HARZA} h

2

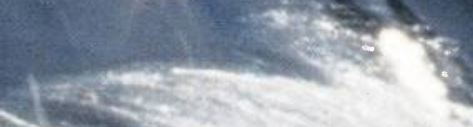

$\mathrm{V}_{2}$
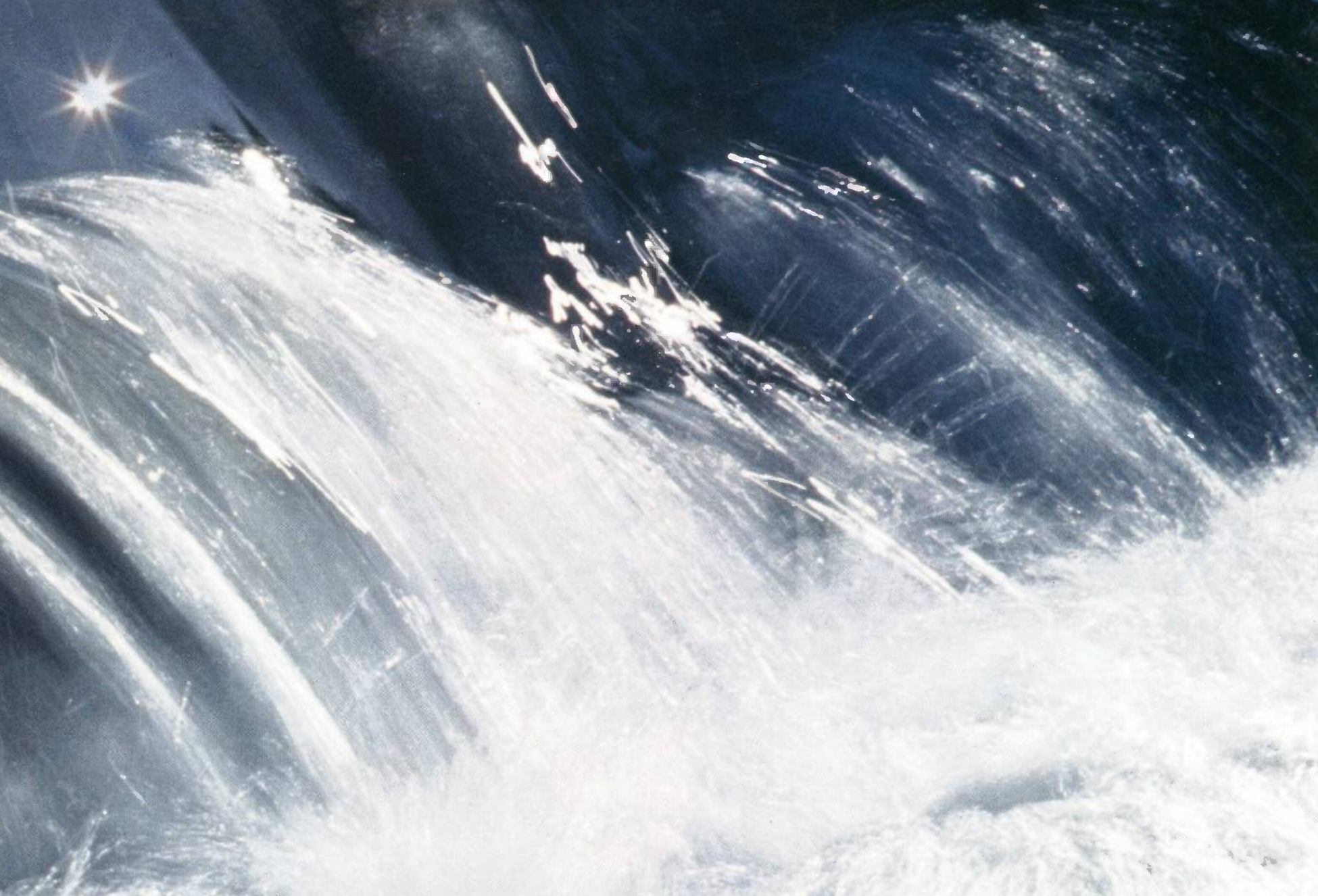
1924

Dix Dam, Harza's first major hydro power project, set a record as the world's highest rockfill dam when it was completed.

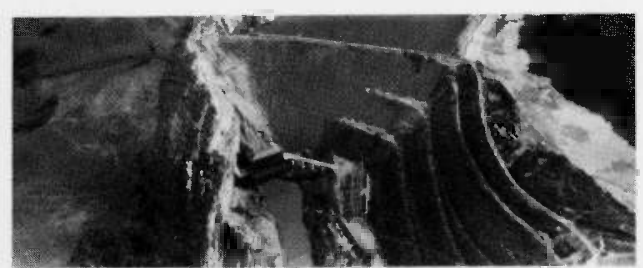

1928

Harza introduced the automatic adjustable blade (Kaplan) turbine in the United States, at the Lake Walk project in Texas.

\section{Table of Contents}

1 Harza Engineering Company

1 Advantages of Hydroelectric Power

2 Hydroelectric Power Plants

4 Renovations and Expansions

5 Licensing, Relicensing, and Inspections

6 Instrumentation and Power Systems

6 Quality Assurance/Quality Control

7 Power Plant Cross-Sections

11 Planning Services

12 Design Services

14 Construction Management Services

15 Representative Hydroelectric Projects 


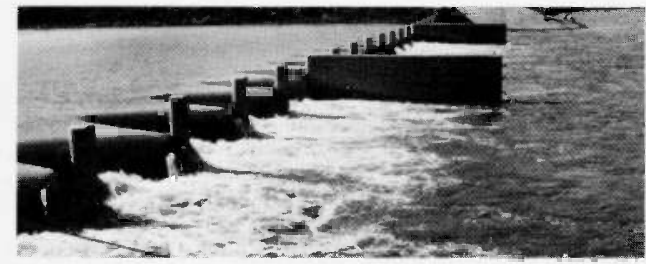

Navigation lock at SanteeCooper, which at its completion was the largest power plant in South Carolina. Santee-Cooper was built on sand without the use of foundation piles

\section{Harza Engineering Company}

stablished in 1920, Harza Engineering Company has grown to be one of the world's largest consulting firms specializing in the development of hydroelectric power. Harza has completed more than 1,500 assignments involving hydroelectric and pumped-storage facilities, transmission and distribution systems, dams, tunnels, and underground structures. Services have ranged from providing a single specialist for short-term consulting work to developing world-class, multiplepurpose projects.

Harza provides complete services for all sizes and types of hydroelectric power plants. These services include:

- National and regional planning

- Conceptual planning

- Feasibility studies

- Project analysis

- Design engineering

- Specifications

- Estimating

- Construction management

- Assistance during project financing, marketing, licensing, start-up, and operation

\section{Advantages of Hydroelectric Power}

17 ydroelectric generation is the only large, economical, and renewable power source proven to be nonpolluting. The reservoir of a hydroelectric project can provide many benefits that are not possible with other forms of generation, including:

- Flood control

- Irrigation

- Municipal and industrial water supply

- Recreation

- Low flow augmentation

- Water quality improvement

- Fish and wild life enhancement

Once built, a hydroelectric project is almost immune to inflationary pressures. The civil works, a major factor in overall costs, have a useful life of 100 years or more. The electrical and mechanical equipment is more reliable than equipment for other types of generation. Operation and maintenance expenses, the only costs subject to inflation, are a small fraction of the total cost. 
1946

For its first overseas assignment, Harza redesigned the 120-MW Río Negro power plant in Uruguay.

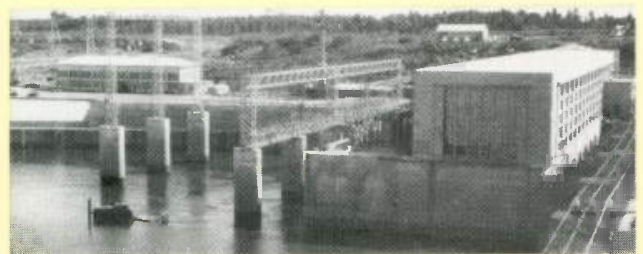

1949

Generators at the Petenwell project in Wisconsin. A Petenwell, Harza's design took advantage of a curve in the river to simplify diversion.

\section{Hydroelectric Power Plants}

arza has been involved in the design of more than 100 hydroelectric projects totaling almost $30,000 \mathrm{MW}$; of these, 20,000 MW are already in operation. These projects range in size from less than $1 \mathrm{MW}$ to the 10,000-MW Guri project in Venezuela.

\section{Major Hydro Projects}

Harza personnel have the experience to plan, design, and manage major hydroelectric projects anywhere in the world. Since the beginning, Harza's leadership position in hydroelectric power has come from a dedication to complete each project on time, within budget, and with optimum performance. We offer complete services for:

- Conventional, underground, and integral intake power plants

- Dams

- Spillways

- Tunnels and penstocks

We routinely handle projects that involve complex engineering design, multiple-purpose facilities, and technical challenges of all types.

We also provide complete project management control services, from producing accurate estimates to controlling costs at all levels.

\section{Small Hydro}

Harza recognizes that small hydro developments are most effectively engineered by a team approach. Our small hydro group is a multidisciplinary team of professionals specializing in complete engineering services for small hydro. This team is fully responsive to all the special needs of small hydro developments, including the budgetary and scheduling constraints inherent to the financial feasibility of these projects.

Further information on Harza's small hydro group is available in a separate brochure.

\section{Pumped-Storage}

Pumped-storage plants provide economical peaking power and improve the availability and reliability of base-load plants. Harza offers a full range of pumped-storage services, from initial siting through licensing, design, and construction. One of our projects is the largest operating pumped-storage facility in the world.

A separate brochure on pumped-storage also is available from Harza.

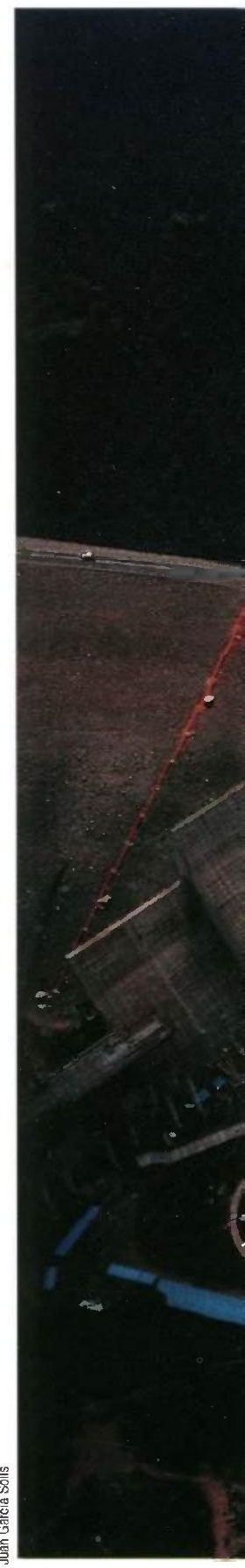




\section{4}

McPhail Falls is one of eight Harza-designed power plants on the Montreal and Michipicoten Rivers in Canada.

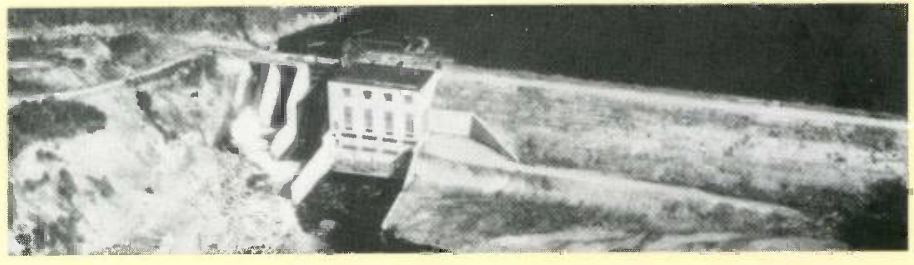

1954

The 82-MW 5 de Noviembre project in El Salvador was the first major underground power plant built in the Western Hemisphere.
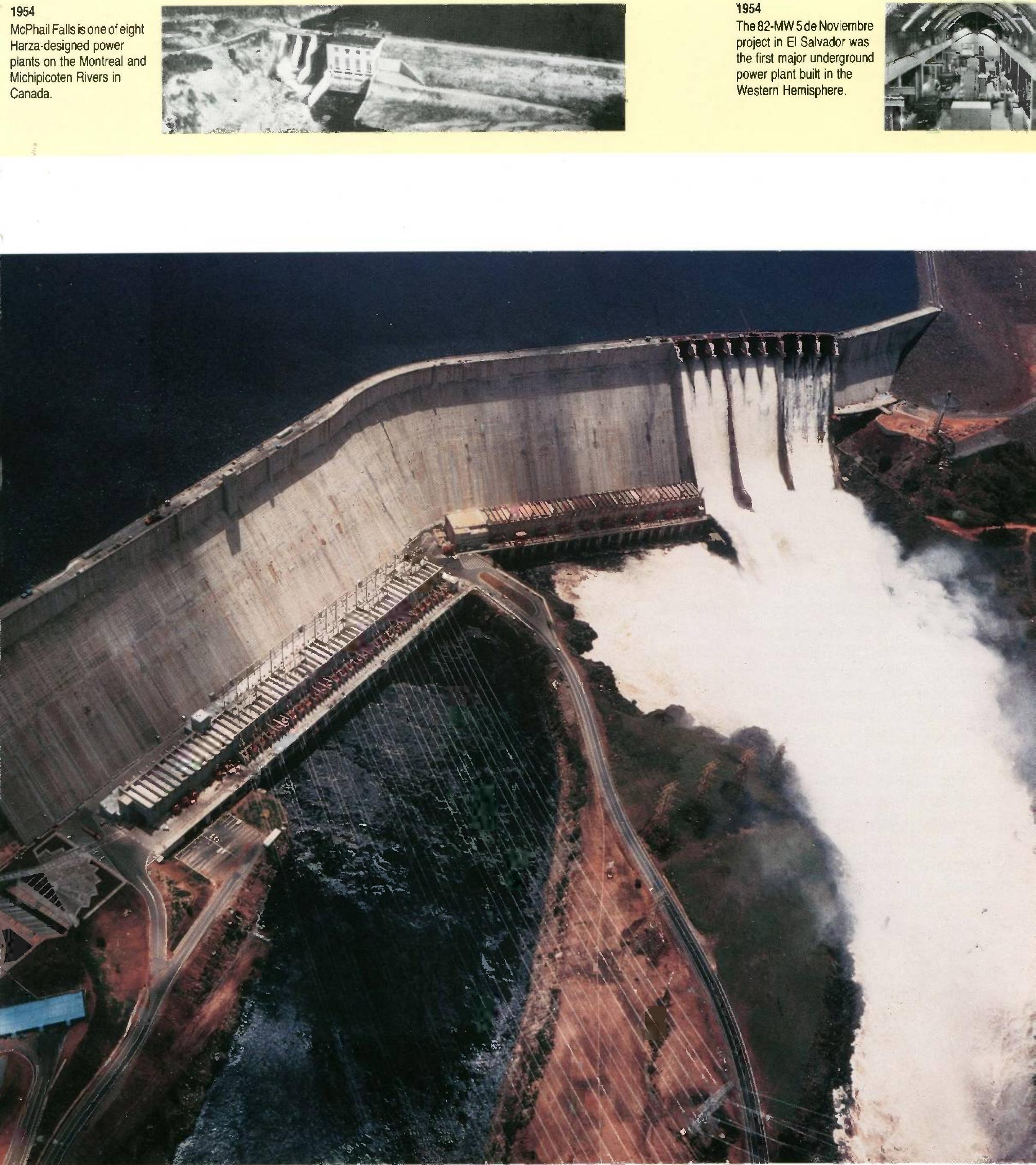

When planning began for the Guri hydroelectric plant in Venezuela, the site potential was too great for the country's energy demand at that time. A small project would have foreclosed full use of the site, and a single, large project could not have been financed. Therefore, the powerhouses, dam, and spillway at Guri were designed to be built in stages without interrupting power production. This staged development resulted in large cost savings, making Guri one of the most economical power plants in the world. At its full commissioning in 1986, at $10,000 \mathrm{MW}$, Guri was the largest hydroelectric power plant in the world. 
1961

Harza designed the first fully automatic controls for fish passage facilities for the Priest Rapids Dam in Washington

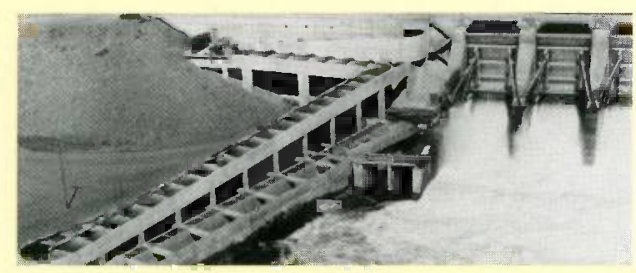

1964

Innovative design solutions at Wanapum, a major project on the Columbia River, included prestressed anchor blocks for very large radial spillway gates, skeleton intake bays for future power additions, and slurry trench foundation cutoff.

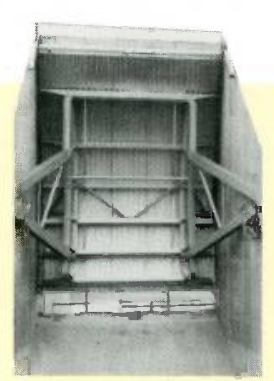

\section{Renovations and Expansions}

$\mathbf{R}$ enovation work is required when plants have deteriorated, equipment requires replacement, the demand for energy has increased, or the facility's license has expired. We offer a wide spectrum of rehabilitation services:

- Hydroelectric power additions

- Stability analyses of dams, and stability improvements

- Foundation investigations and seepage control

- Spillway design

- Flood and dam break analyses

- Gate and outlet works modifications

- Telemetering and remote/automatic operations systems

- Insurance inspections

- Concrete and steel rehabilitation

- Erosion control and scour repair

Expansion of existing sites provides peak-load generating capacity and increases energy production. At dams initially built to provide water supply or flood control, power stations can be added to improve the economics of the project. This development sequence allows dam design and construction to proceed before approval is obtained from regulatory agencies such as the U.S. Federal Energy Regulatory Commission.

Much of Harza's renovation and expansion experience has required innovative designs. During the restoration and expansion of the Gregory B. Jarvis Dam in New York, Harza recommended tunneling through the existing dam to access water in the reservoir for power generation. The work also included design of a post-tensioned anchorage system to improve spillway stability.

Harza's experience with hydro power recapture at existing water supply systems includes expansion work at the Summer Falls Dam, built at the head of a 165 -ft waterfall on the Columbia River. Two units were installed to generate $92 \mathrm{MW}$ from water released for irrigation.

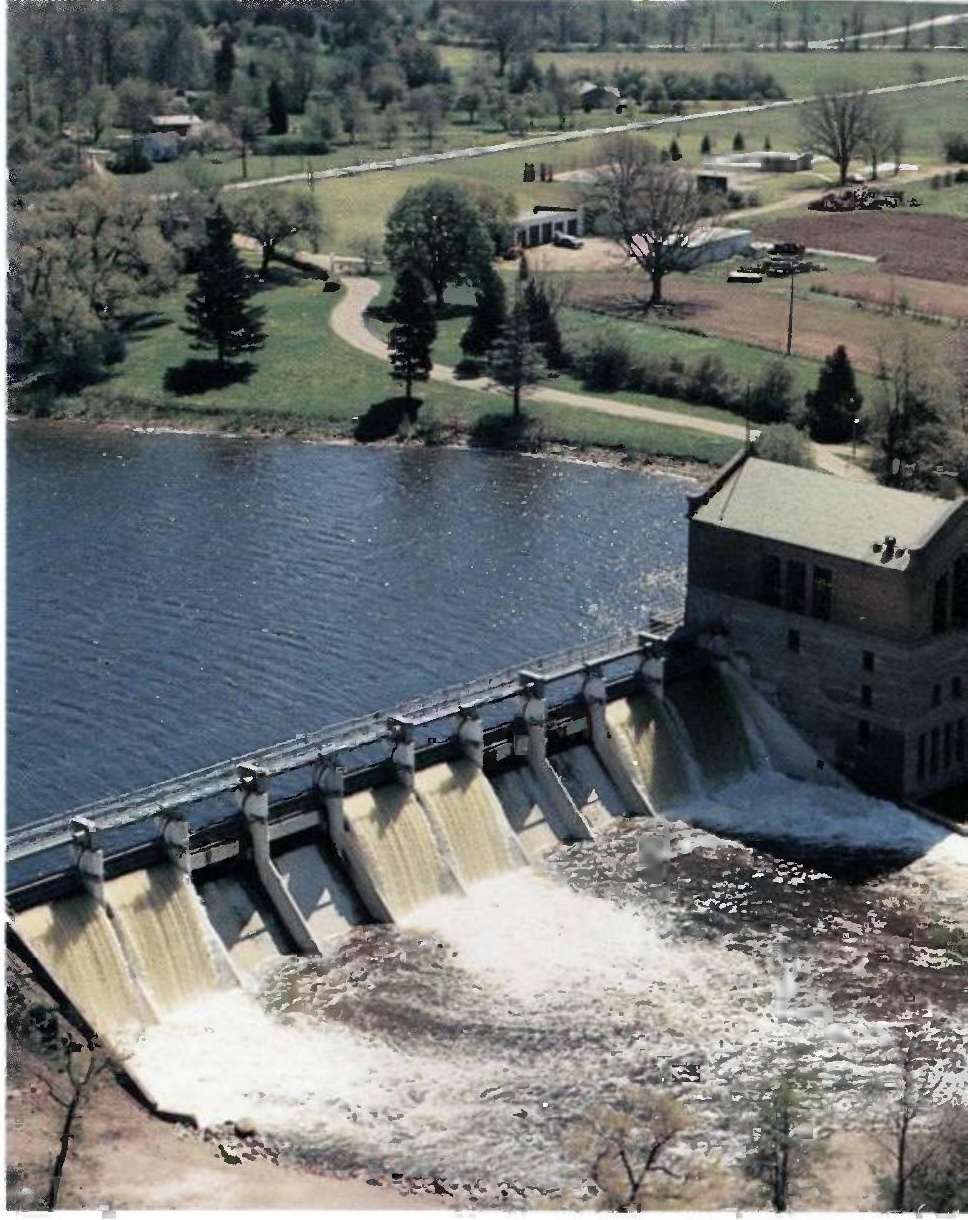

At Barton Dam near Ann Arbor, Michigan, Harza completed a power station that accommodates a new 900-kW Kaplan turbine. The existing, open flume powerhouse was preserved, even though it was built for a different type of turbine.

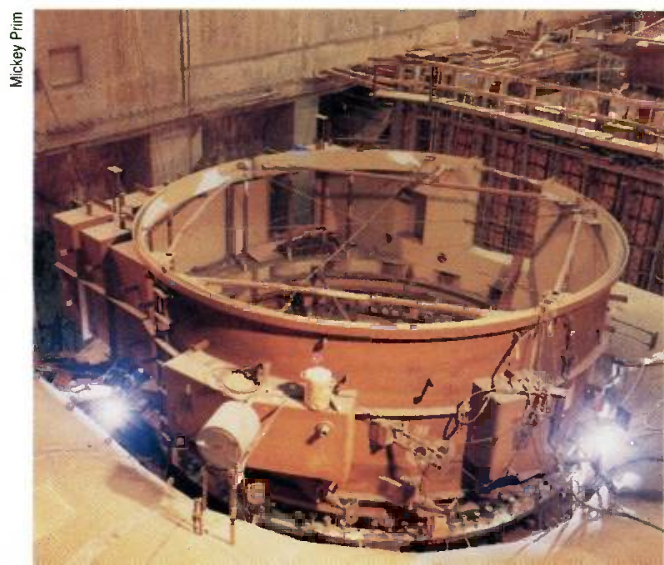

Two 196-MW generating units were added at the Boundary Dam in Washington, to generate waterpower that was previously lost due to spilling. Expansion work harnessed $60 \%$ of the water that had been wasted. 
1965

At the Sam Rayburn project in Texas, a monolithic construction concept was introduced for the powerhouse structure built on sand foundation.

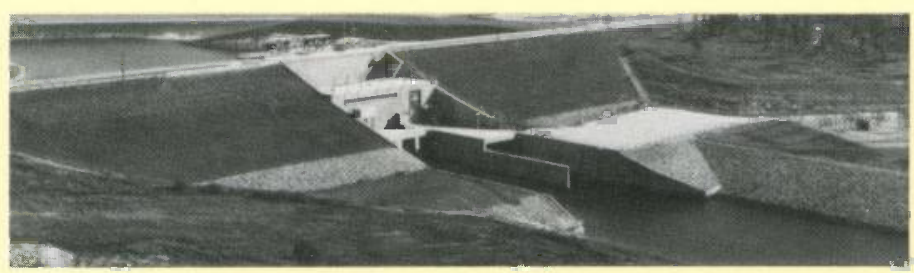

1967

Angat in the Philippines consists of a $200-\mathrm{MW}$ pittype powerhouse, rockfill dam, and an auxiliary 12MW surface powerhouse.

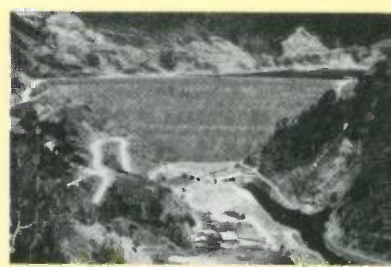

\section{Licensing, Relicensing, and Inspections}

H arza has developed more than $60 \mathrm{FERC}$ license applications representing 12,500 MW capacity. As part of this work, we provide regulatory assistance for:

- Preparation of permit applications

- Agency and public consultation programs

- Preparation of license applications

- Licensing support activities

- Expert witness testimony

Throughout the licensing or relicensing process, studies performed by Harza can be used to document that the applicant's plan for the facility is the best development of the resource consistent with state or federal comprehensive plans. Documentation can include:

- Need-for-power studies

- Power purchase agreements

- Generation system analyses

- Economic studies

- Projectfinancing studies

In the critical area of environmental reports, we help applicants comply with current $F E R C$ regulations that require complete environmental and resource management analyses and consultation with concerned agencies.

In the last three years Harza has completed more than 100 inspections required to comply with FERC regulations and more than 50 required by individual states, other federal agencies, and several countries. Many inspections have employed techniques such as underwater video inspection and innovative foundation testing.

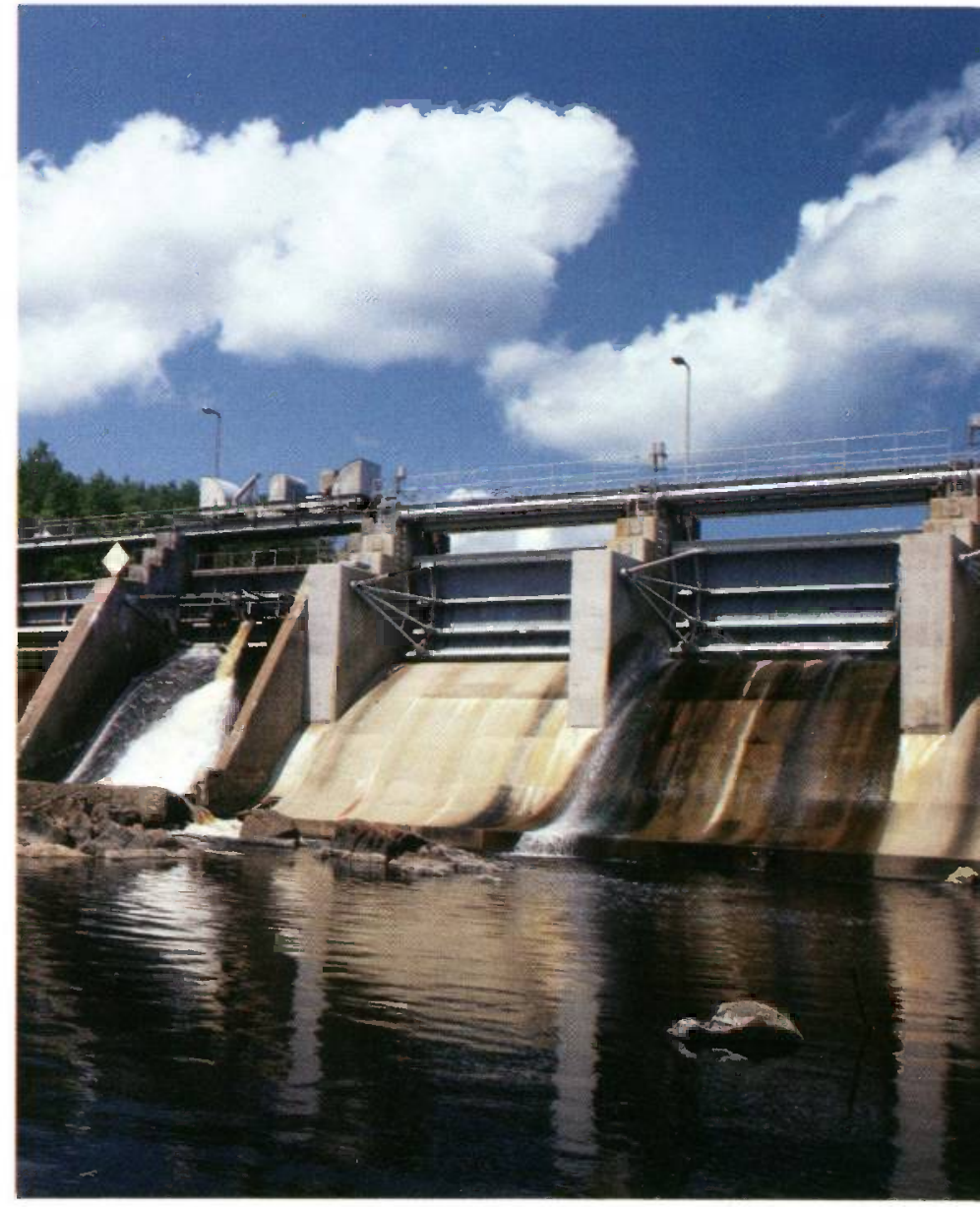

For the 17.2-MW Grandfather Falls project in Wisconsin, Harza prepared a relicense application.

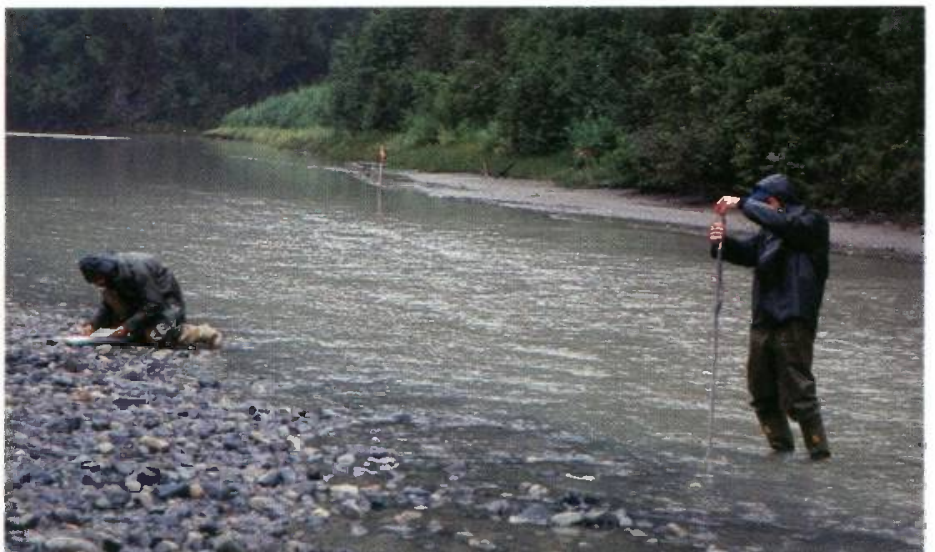

Because a hydroelectric project must be acceptable to agencies concerned with the environment, Harza specialists are involved throughout the licensing or relicensing process. 
1969

Burfell in lceland consists of a diversion dam, intake, 105-MW powerhouse, and 71 miles of $220-\mathrm{kV}$ transmis sion line.

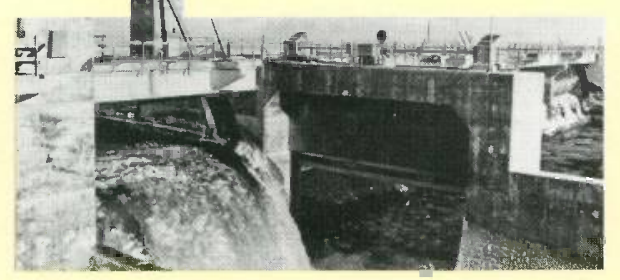

1969

Kinzua/Seneca in Pennsylvania was Harza's first pumped-storage project

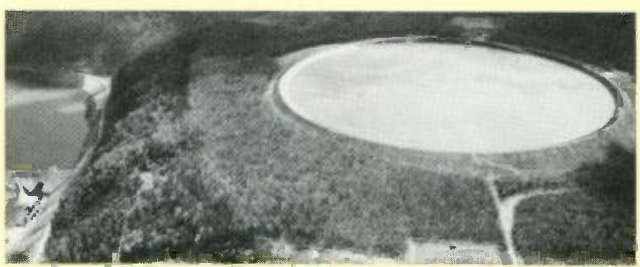

\section{Instrumentation and Power Systems}

P ower plant automation is an effective way to optimize operations and increase overall plant efficiency. Harza has designed state-of-the-art control and monitoring systems, including:

- Systems for small installations

- Remote control systems for unattended plants and switchyards

- Central control systems for the operation and dispatch of large hydroelectric plants for integration into utility systems

Harza has an in-house multidisciplinary team of architects and civil and electrical engineers who design control centers tailored to the client's needs and operating requirements. As a part of this service, we often develop software packages for real-time analysis of system characteristics, parameters, and performance.

Our staff of transmission line and substation specialists has provided power plant, transmission, and distribution systems development services in 19 countries. This experience covers a broad range of transmission line voltages in a wide variety of geographic conditions. Our distribution systems range in complexity from conventional systems for small villages to examples of the latest technology for major metropoli$\tan$ areas.

\section{Quality Assurance/Quality Control}

1 uality assurance is an integral part of Harza's services. Harza quality assurance programs emphasize controlling each phase of a project as it occurs. Experienced senior professional staff review the design and coordinate the planning, design, and construction disciplines to ensure an economical and successfully engineered project.

Harza also offers quality assurance/quality control consultation services directly to our clients. These services include:

- Program development, review, and management

- Program indoctrination and training

- Audit and surveillance during design, construction, and operation

- Surveillance of subsurface investigation and testing

- Field material testing

- Surveillance of shop and field fabrication

- Dam safety inspections

- Contracting and monitoring outside inspections

- Supplier/contractor prequalification and evaluation

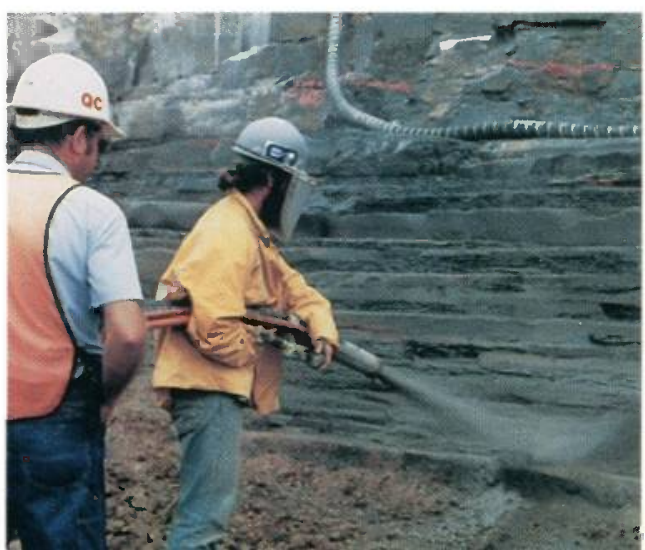

Surveillance during construction is an important part of the Harza quality assurance program. 


\section{Cross-Sections of Harza-Designed Power Plants}

\footnotetext{
1 arza has worked with virtually every major hydroelectric

equipment manufacturer, and we offer specialists in every aspect of design, specifications, bidding, inspections, testing, and start-up. Turbine types that we have selected and procured include Pelton (impulse) turbines for high-head projects, Francis turbines for medium-head projects, and Kaplan, fixed-blade propeller, bulb, and tube turbines for lower-head facilities. Generating unit sizes are based upon flow and head conditions, available space, flexibility of operation, and other practical considerations such as current technology, transportation limitations, and manufacturing competitiveness.

Our experience also extends to every type of power plant: conventional indoor, semi-outdoor, outdoor, pit-type, integral intake, and underground. Harza-designed power plants are in operation worldwide. Representations of some of these plants are shown on the next three pages.
} 


\section{Integral Intake Power Plants}

\section{Sam Rayburn}

Texas

Two 31-MW Units

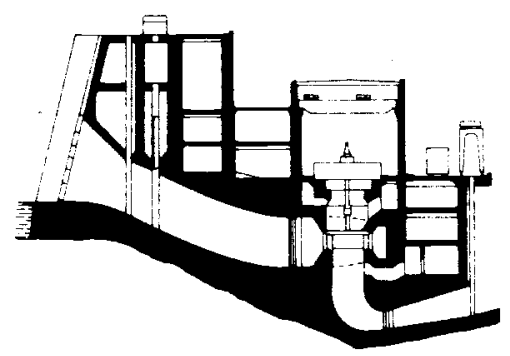

Markland

Indiana

Three 31-MW Units; Semi-Outdoor

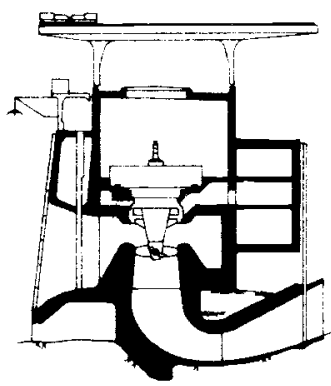

15 de Septiembre

El Salvador

Two 78.3-MW Units

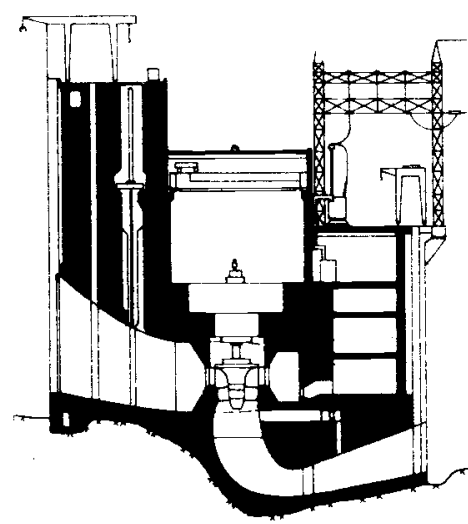

\section{Underground Power Plants}

\section{5 de Noviembre \\ El Salvador \\ Unit No. 4, 15 MW}

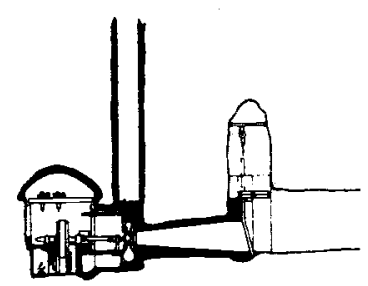

Maithon

India

Three 21-MW Units

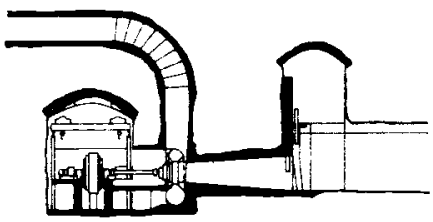

Ambuklao

Philippines

Three 25-MW Units

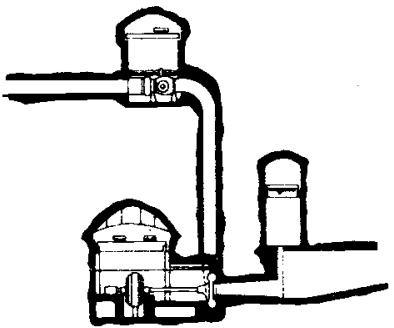

\section{Small Power Plants}

Strawberry Creek

Wyoming

Three .54-MW Units

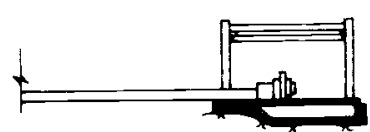

Barton Dam

Michigan

$.9 M W$

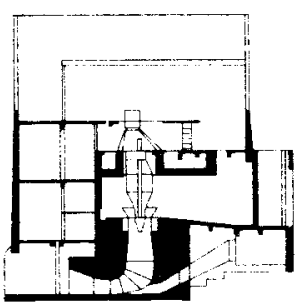

Dillon Dam

Colorado

$2 M W$

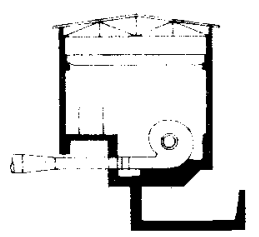




\section{Conventional Above-Ground Power Plants}

\section{Guajoyo}

Ei Salvador

15 MW; Pit-Type

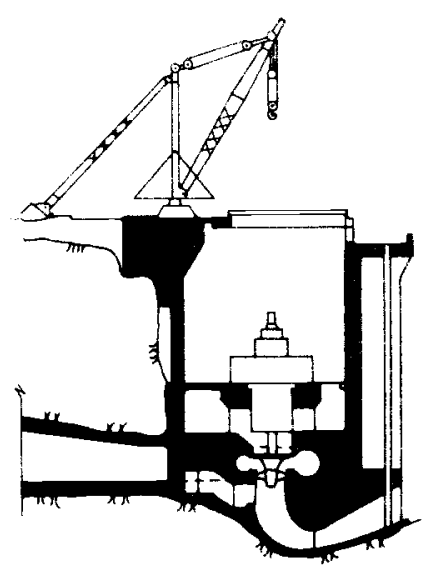

Rio Lindo

Honduras

Four 20-MW Units

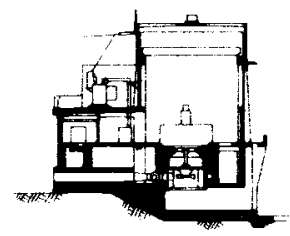

Main Canal Headworks Washington $24.4 M W$

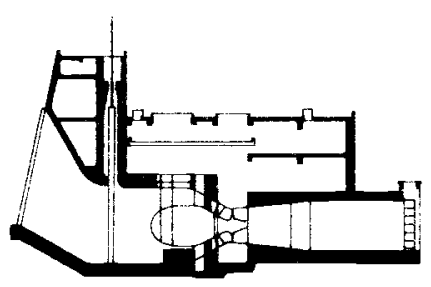

\section{Conventional Above-Ground Power Plants}

\section{Burfell}

iceland

Three 35-MW Units

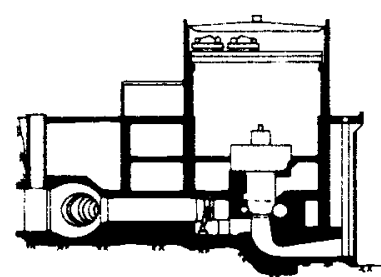

Summer Falls

Washington

Two 46.2-MW Units

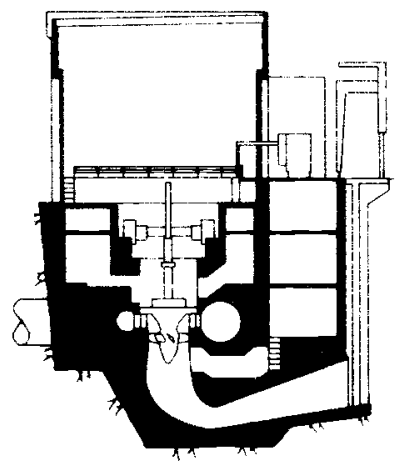

Angat

Philippines

Four 50-MW Units; Pit-Type

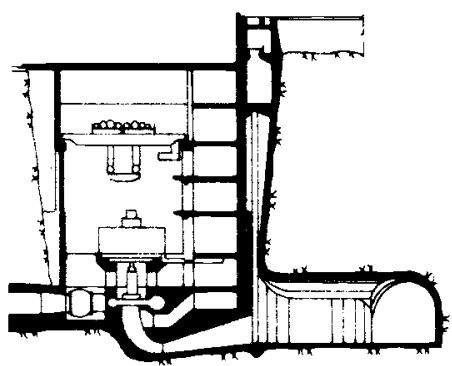

\section{Conventional Above-Ground Power Plants}

Hartwell

Georgia and South Carolina

Four 66-MW Units; Outdoor-Type

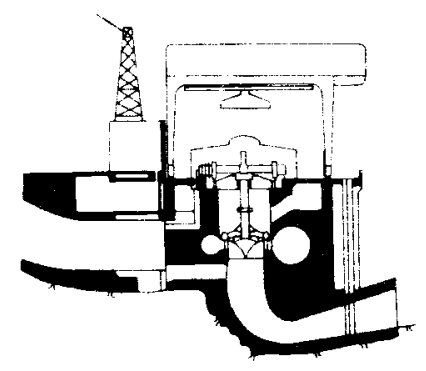

Guri Powerhouse No. 1

Venezuela

Unit No. 3, $175.8 \mathrm{MW}$

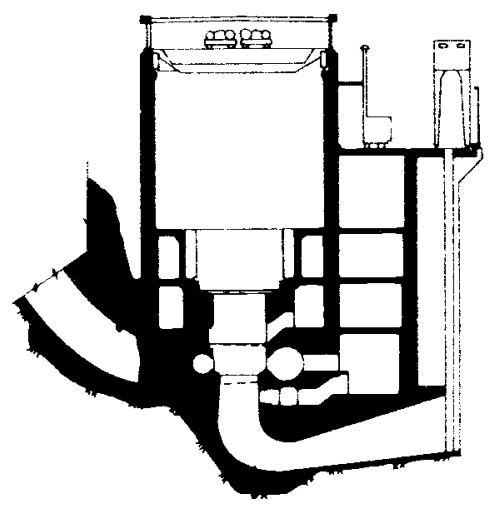

Guri Powerhouse No. 2

Venezuela

Ten 630-MW Units

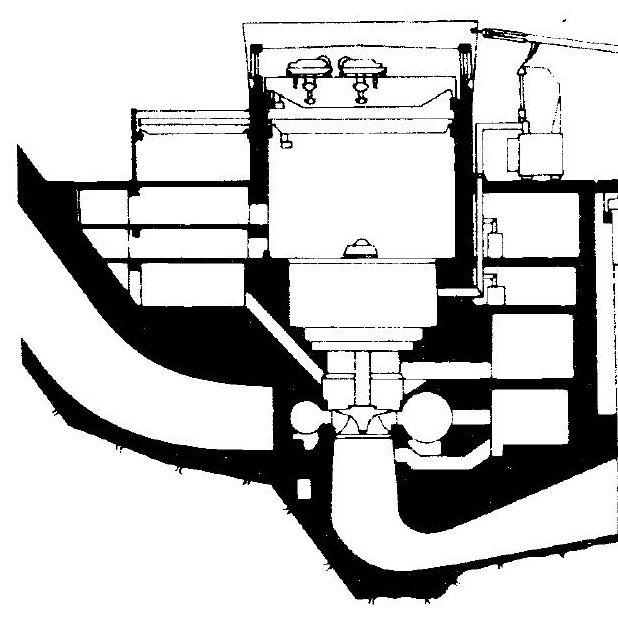


1971

The Río Lindo powerhouse in Honduras was built in two penstock and two 20-MW units were installed in 1971; expansion work completed in 1978 doubled the plant's capacity. stages. A 5-km-long

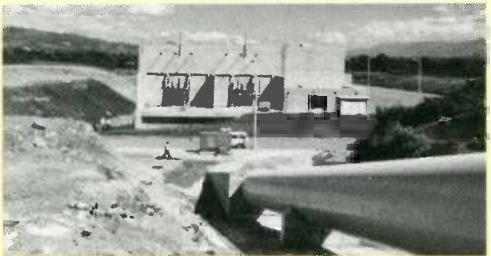

\section{Planning Services}

17 arza undertakes river planning to achieve the most practicable, economical, environmentally viable, and beneficial use of water resources for:

- Power generation

- Irrigation and water supply

- Flood control and navigation

- Water quality

River planning usually has the objective of establishing a master plan for the long-term development of a river basin and identification of the highest-priority projects.

Harza recognizes the importance of planning to a project's success in meeting cost and performance objectives. Topographic, geologic, and environmental constraints must be accommodated in analyzing project costs. Alternative costs are compared to assist with the choice of basic project parameters: project arrangement, reservoir headwater levels, turbine type and size, and total installed capacity.

During project planning, Harza gives special attention to sizing the project to meet power system requirements, designing it to serve additional needs, and accommodating and enhancing existing environmental conditions.

The planning team consists of, as required:

- Planning engineers

- Hydraulic, civil, geotechnical, electrical, and mechanical engineers

- Hydrologists and geologists

- Estimators and schedulers

- Economists, market and financial analysts

- Ecologists, biologists (aquatic and terrestrial), and sociologists

- Recreation planners, archaeologists, and anthropologists

Harza can provide assistance with additional planning services such as water resource development and electric systems planning, utility management, and training.
1977

At the Karun project in Iran, concrete penstocks on the upstream face of the 650-ft-high, double-curvature arch dam pass horizontally through the lower part of the dam. This design minimized the length of steel liner and structural loading on the dam and eliminated the need for costly independent intake towers.

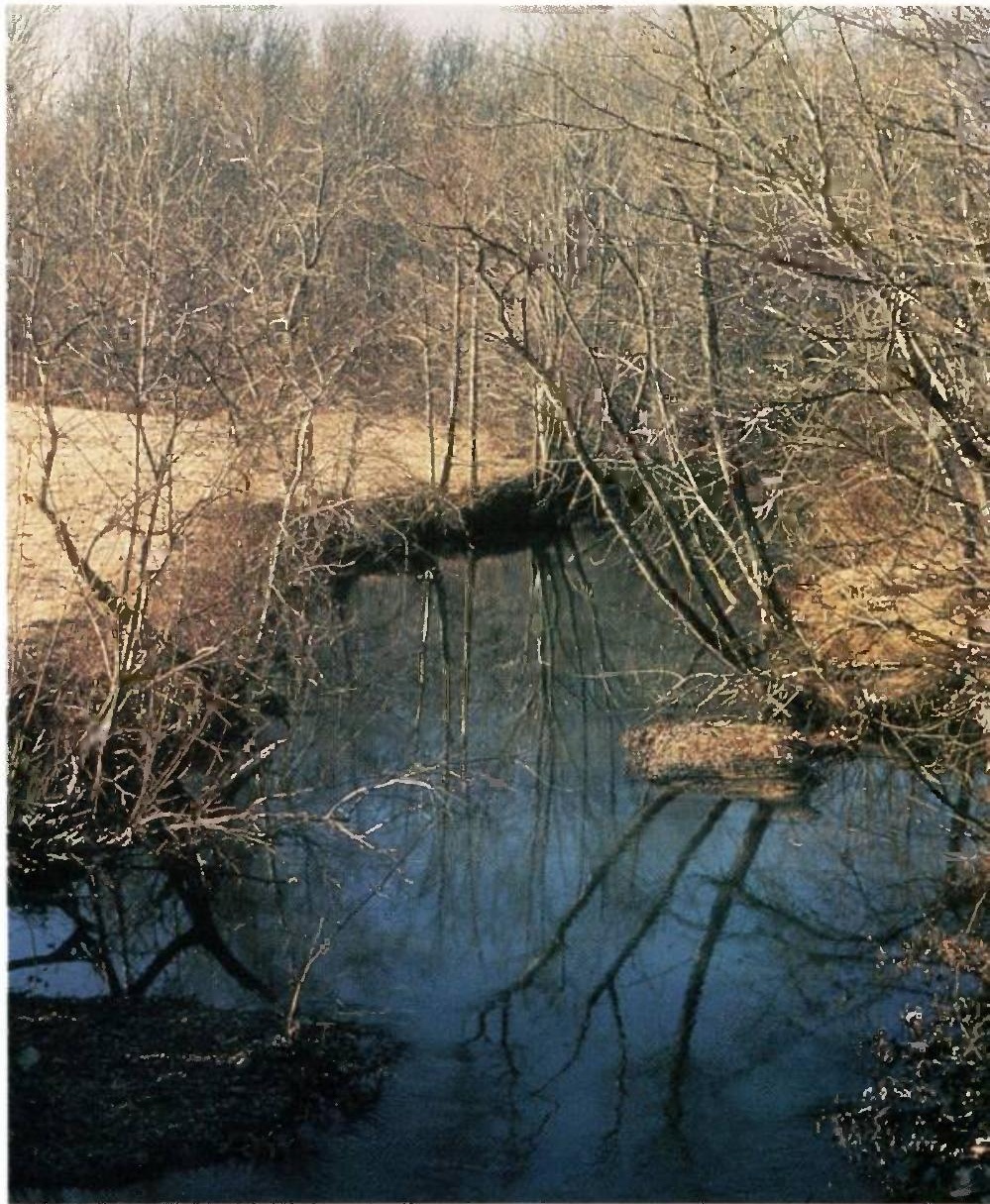

A pumped-storage project requires siting in mountainous country where two reservoirs can be located with enough vertical distance. between them to create sufficient head. For the Oglethorpe pumpedstorage project in northern Georgia, 67 possible sites were identified; of these, three were selected for more detailed study. This small stream, at one site under consideration, would fill the lower reservoir.

\section{Some of the rivers Harza has studied:}

Brazos, Texas

Hongshui, China

Yangtze, China

Oswego, New York

Hudson, New York

Black, New York

Cache la Poudre, Colorado

Susitna, Alaska

Powder, Wyoming

Blue, Colorado

Upper South Han, Korea

South Columbia Basin, Washington

Gauley and Kanawha, West Virginia
Puyango-Tumbes Basin, Ecuador and Peru

Uribante-Caparo, Venezuela

Chimbo, Ecuador

South Platte Basin, Colorado

Yarmouk, Jordan

Patía, Colombia

Grande, Bolivia

Karun and Marun, Iran

Caroní, Venezuela

Indus, Pakistan

Lempa, El Salvador 


\section{7}

Harza's solution to river diversion at Cerron Grande in EI Salvador involved excavating the river valley and filling it with dam material during dry seasons. During the wet seasons, floods were allowed to flow over the original channel. The dam was built during the third dry season. This solution allowed the diversion tunnel to be a fraction of the size required to pass wet season floods.

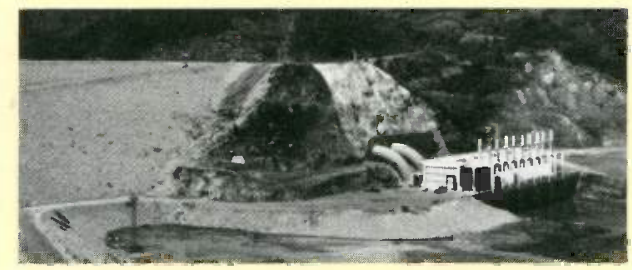

1984

Despite low and varying head, an economical hydroelectric facility was created at the Main Canal project in Washington, with the use of a single, variable-pitch bulb turbine unit.

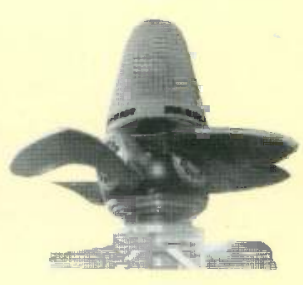

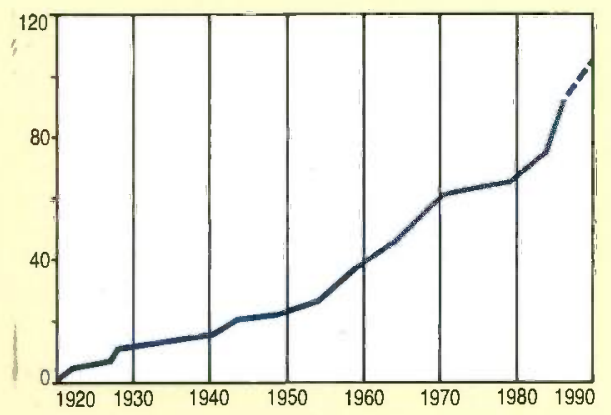
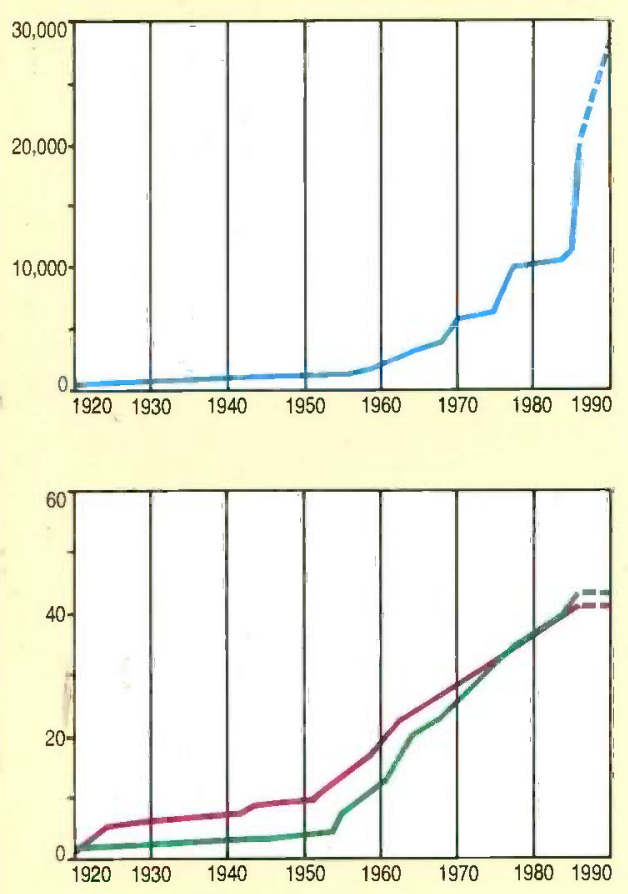

Number of power plants

Ninety-three hydroelectric power plants engineered by Harza are currently in operation.

MW

These plants produce $20,000 \mathrm{MW}$ of generating capacity.

International experience

Harza has worked on hydroelectric projects in 43 countries.

\section{Design Services}

1 arza offers complete civil, geotechnical, mechanical, and electrical design services for hydro power projects. Our objective is to bring projects into service on time and within budget by combining design engineering skills with cost-saving technology. Over the years, we have encountered hundreds of challenging situations that have resulted in innovative solutions.

\section{Power Generation Equipment}

- Design parameters and specifications for turbines, generators, and other electro-mechanical equipment

- Electro-mechanical systems

Water Conveyance Structures and Related Facilities

- River diversion facilities

- Powercanals

- Desiltation works

- Power intakes with and without fish screens

- Power conduits and high-pressure penstocks

- Surge tanks and air chambers

- Spillways

- Outletworks

- Gates, trashracks, and bulkheads

- Navigation locks and channels

\section{Structures}

- Concrete arch, gravity, and gravity arch dams

- Roller-compacted concrete dams

- Rockfill and embankment dams

- Staged construction of dams

- Powerhouses

- Underground structures and supports

\section{Foundations}

- Foundation investigations and treatment

- Foundation and materials testing

- Seepage cut-offs (grout curtains, slurry trenches, concrete curtain walls, and impermeable upstream blankets)

- Drainage adits and drainage curtains

- Post-tensioned anchors

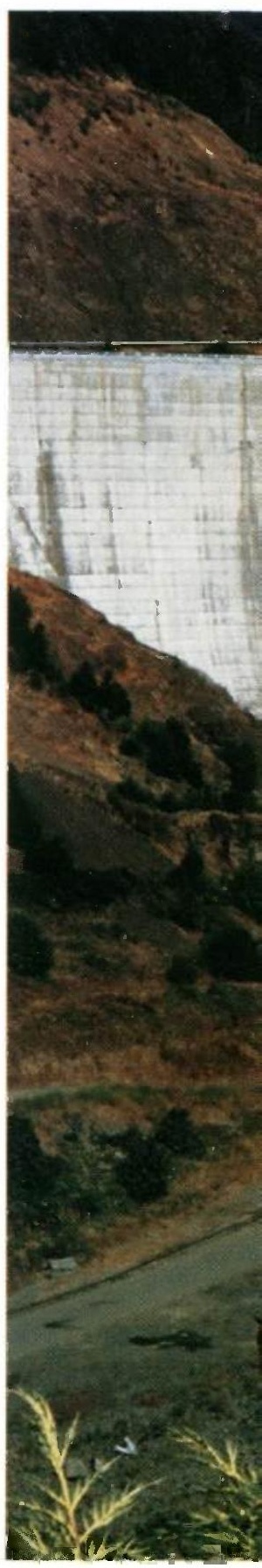

Experience in the United States

Harza has worked on hydroelectric projects in 41 states. 
1986

Construction continued at the King Talal Dam in Jordan. Expansion of the project called for raising the dam and reservoir by 16 meters, and adding a 2.7-MW power plant.

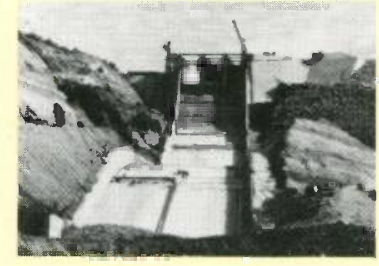

\section{6}

In New York, Harza's small hydro group has worked on 40 projects. Among these is the Philadelphia Dam, where the site was rehabilitated and a 3.6.MW powerhouse was installed.
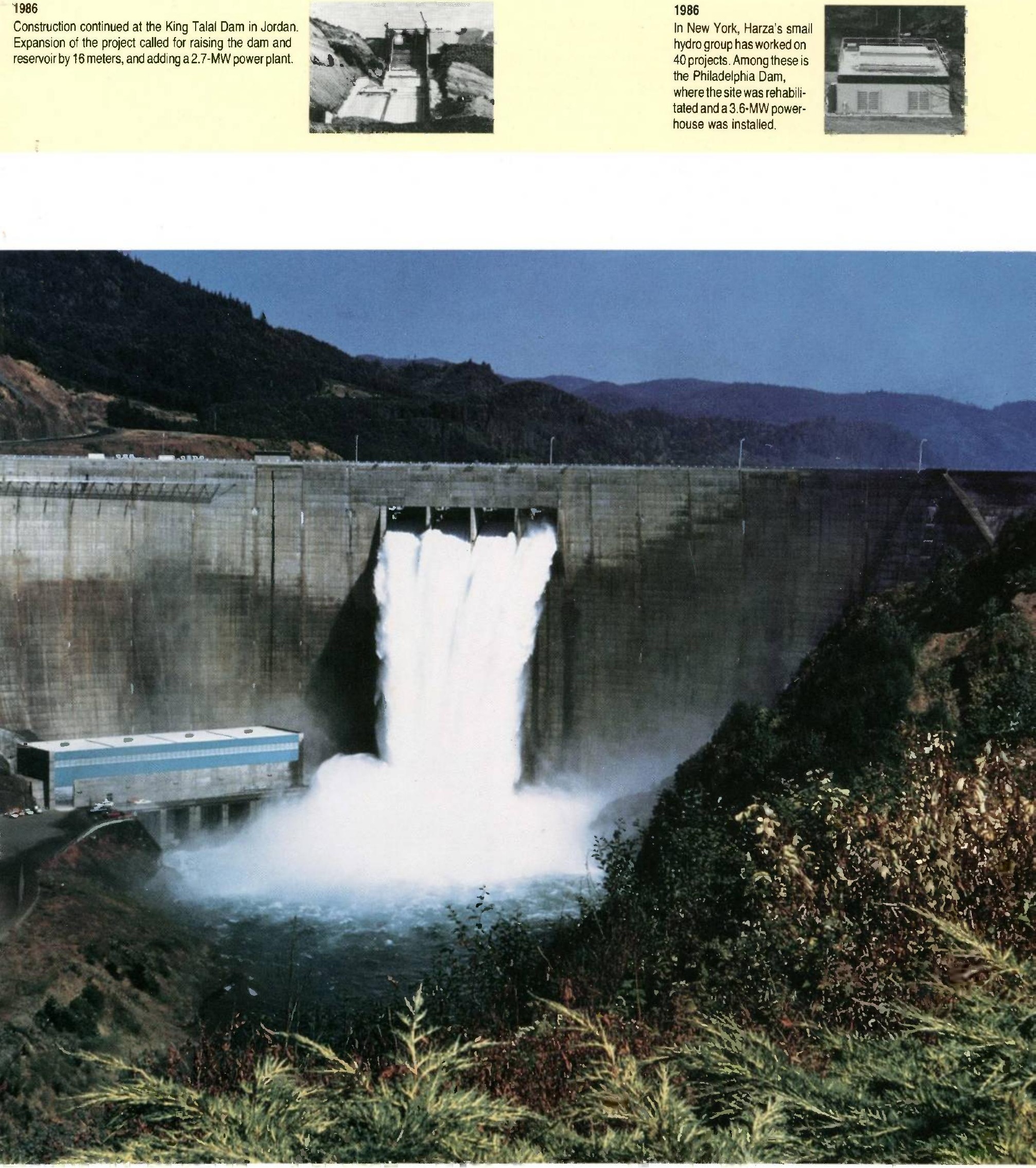

The Mossyrock project in Washington has a 606-ft thin-arch concrete dam and the first large free-fall spillway (276,000 cfs). The project also features one of the first free-span, articulated pressure penstock section and support systems between a powerhouse and a thin-arch dam. 


\section{6}

Harza completed the 2,100 MW Bath County pumped storage facility in Virginia, the world's largest.

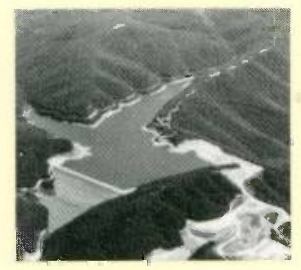

1986

The 10,000-MW Guri complex in Venezuela was constructed over a 22-year period. At its completion, Guri was the largest hydroelectric power plant in the world.
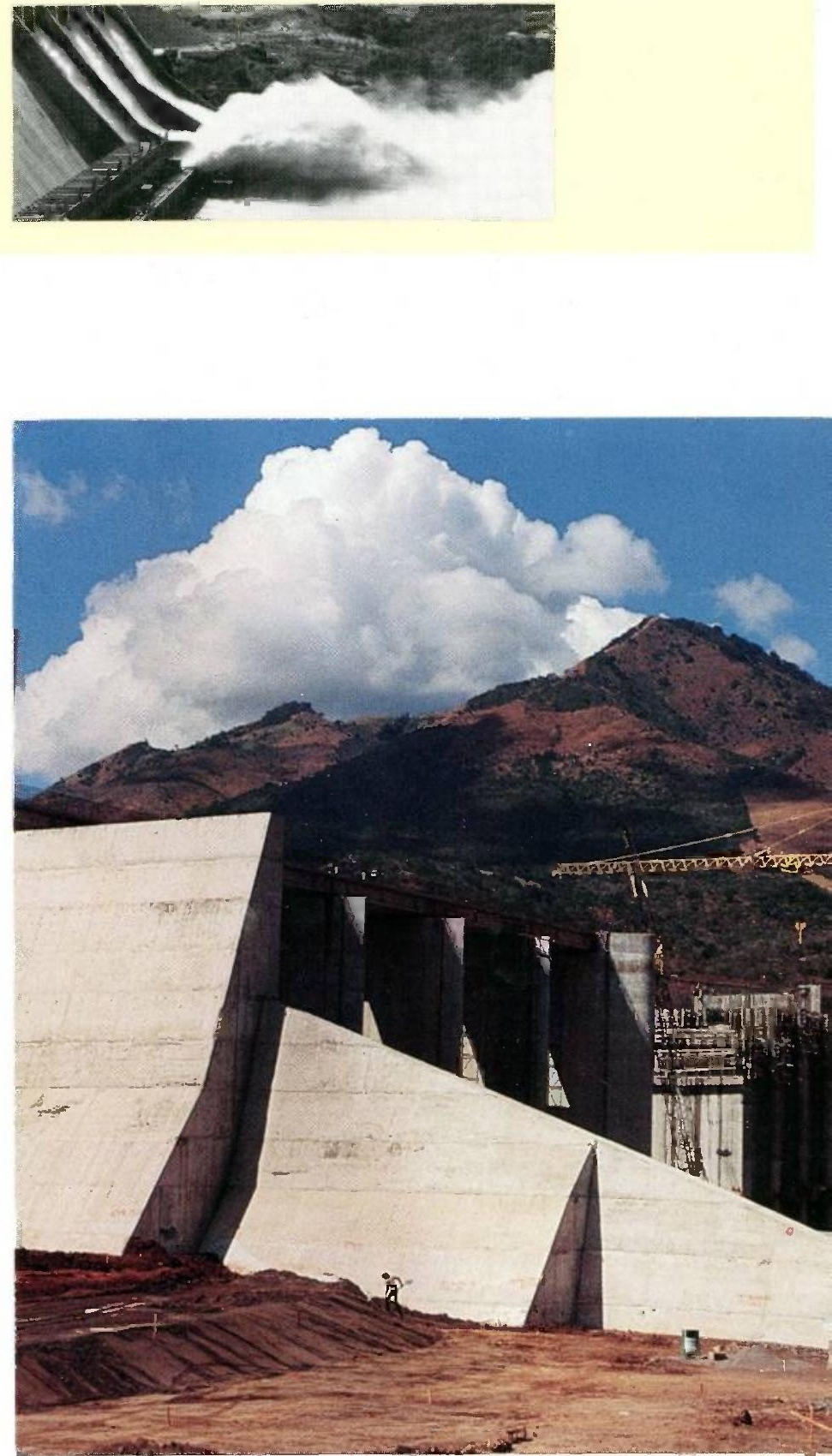

Harza has provided planning, design, and construction management for four major hydroelectric projects on the Rio Lempa in EI Salvador, including the 15 de Septiembre project shown above. arza offers construction services customized for hydroelectric power plants of all sizes. Our construction staff provides these services at any level, from supplying key personnel who supplement a client's staff to furnishing an entire field engineering force. During just the last 10 years, we have provided construction management services for more than 35 major hydroelectric projects. Construction management services can be provided effectively from project conception throughout the project.

\section{Services Preceding Construction}

- Cost estimates

- Evaluations of materials and methods

- Inputs to contract documents and technical specifications

- Prequalification evaluations

- Bid evaluation and contract negotiations

- Constructability reviews

\section{Services During Construction}

- Developing and maintaining project information and control systems

- Procuring and expediting equipment and materials

- Establishing construction site layout

- Detailed construction scheduling

- Administering contracts

- Costmonitoring

- Reporting daily construction activities

- Inspecting civil works and electrical-mechanical installations

- Shop fabrication inspections

- Approving the contractor's progress payments

- Issuing final certification and initial start-up

- Claims evaluation

- Construction follow-up and instrumentation monitoring

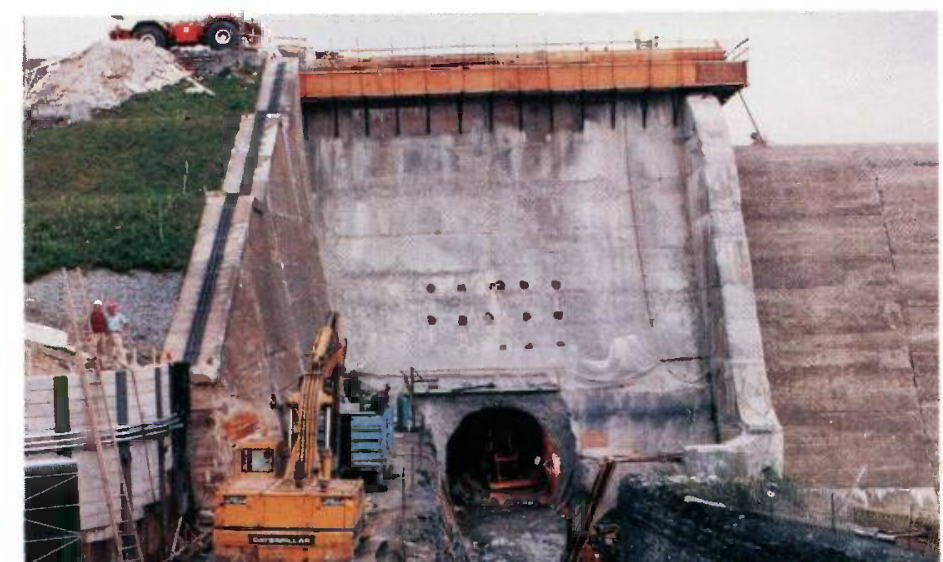

At the Gregory $B$.

Jarvis Dam, a 9-

MW power plant was added and extensive structural changes were made to the dam. The dam was originally built to supply water to the Erie Canal and the city of Utica, New York.

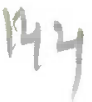




\section{Representative Hydroelectric Projects}

\section{Kaplan}

\begin{tabular}{|c|c|c|c|c|c|c|c|c|c|}
\hline \multicolumn{3}{|l|}{ 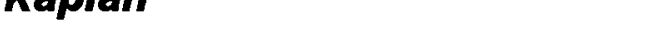 } & \multirow{2}{*}{ Number } & \multicolumn{3}{|c|}{ - Turbines } & \multirow[b]{2}{*}{$\begin{array}{l}\text { Generator } \\
\text { Rating } \\
\text { (kVA) }\end{array}$} & \multirow[b]{2}{*}{$\begin{array}{c}\text { Turbine } \\
\text { Manufacturer }\end{array}$} & \multirow[b]{2}{*}{$\begin{array}{l}\text { Generator } \\
\text { Manufacturer }\end{array}$} \\
\hline Name of Project & Location & $\begin{array}{c}\text { Year } \\
\text { Initial } \\
\text { Operation }\end{array}$ & & $\begin{array}{l}\text { Head } \\
\text { (m) }\end{array}$ & $\begin{array}{l}\text { Rating - } \\
\text { MW }\end{array}$ & $\begin{array}{l}\text { Speed } \\
\text { (ipm) }\end{array}$ & & & \\
\hline BoxCanyon & Washington & 1955 & 4 & 12 & 18 & 100 & 16,667 & Allis-Chalmers & Elliott, USA \\
\hline Castle Rock & Wisconsin & 1950 & 5 & 9 & 3.2 & 150 & 3,750 & $\begin{array}{l}\text { S.M.Smith, } \\
\text { USA }\end{array}$ & Allis-Chalmers \\
\hline Corpus & $\begin{array}{l}\text { Argentina and } \\
\text { Paraguay }\end{array}$ & $\begin{array}{l}\text { Construction } \\
\text { Deferred }\end{array}$ & 32 & 22 & 143 & 73 & 160,000 & To Be Awarded & To Be Awarded \\
\hline Gavins Point & South Dakota & 1956 & 3 & 15 & 40 & 75 & 35,100 & Baldwin L.H. & Allis-Chalmers \\
\hline Gartshore Falls & Canada & 1958 & 1 & 34 & 23 & 240 & 22,222 & $\begin{array}{l}\text { Dominion } \\
\text { Engineering } \\
\text { Works }\end{array}$ & $\begin{array}{l}\text { Canadian } \\
\text { Westinghouse }\end{array}$ \\
\hline Guajoyo & El Salvador & 1964 & 1 & 42 & 15 & 300 & 16,667 & Toshiba & Toshiba \\
\hline Hogg Falls & Canada & 1965 & 1 & 23 & 16 & 200 & 16,667 & $\begin{array}{l}\text { Dominion } \\
\text { Engineering } \\
\text { Works }\end{array}$ & GE, Canada \\
\hline Hollingsworth & Canada & 1959 & 1 & 33 & 23 & 200 & 22,222 & $\begin{array}{l}\text { Dominion } \\
\text { Engineering } \\
\text { Works }\end{array}$ & GE, Canada \\
\hline Markland & Indiana & 1966 & 3 & 10 & 31 & 64 & 27,000 & Allis-Chalmers & GE, USA \\
\hline Panchet Hill & India & 1959 & 1 & 25 & 42 & 125 & 47,060 & Nohab, Sweden & ASEA, Sweden \\
\hline Petenwell & Wisconsin & 1949 & 4 & 13 & 5.4 & 164 & 6,250 & $\begin{array}{l}\text { S.M. Smith, } \\
\text { USA }\end{array}$ & GE, USA \\
\hline Priest Rapids & Washington & 1961 & 10 & 24 & 85 & 86 & 83,000 & $\begin{array}{l}\text { English } \\
\text { Electric }\end{array}$ & $\begin{array}{l}\text { English } \\
\text { Electric }\end{array}$ \\
\hline 15 de Septiembre & El Salvador & 1983 & 2 & 30 & 92 & 106 & 87,000 & $\begin{array}{l}\text { Mercánica de } \\
\text { la Peña, Voith, } \\
\text { Spain-Germany }\end{array}$ & Hitachi \\
\hline Rio Negro & Uruguay & 1946 & 4 & 21 & 30 & 125 & 32,000 & $\begin{array}{l}\text { S.M. Smith, } \\
\text { USA }\end{array}$ & GE, USA \\
\hline Robert S. Kerr & Oklahoma & 1970 & 4 & 12 & 34 & 75 & 28,667 & Allis-Chalmers & GE, USA \\
\hline Sam Rayburn & Texas & 1965 & 2 & 21 & 31 & 120 & 26,000 & Allis-Chalmers & Elliott \\
\hline Santee-Cooper & South Carolina & 1942 & 2 & 21 & 30 & 120 & 34,000 & Allis-Chalmers & Westinghouse \\
\hline & & & 1 & 21 & 9.9 & 200 & 11,350 & Allis-Chalmers & $\mathrm{GE}, \mathrm{USA}$ \\
\hline Scott Falls & Canada & 1952 & 2 & 21 & 7.5 & 225 & 8,500 & $\begin{array}{l}\text { S.M. Smith, } \\
\text { Canada }\end{array}$ & GE,Canada \\
\hline Summer Falls & Washington & 1985 & 2 & 49 & 47 & 200 & 48,672 & Toshiba & Toshiba \\
\hline Ullum & Argentina & $\begin{array}{c}\text { Under } \\
\text { Construction } \\
\end{array}$ & 1 & 44 & 41 & 176 & 50,000 & Nohab, Sweden & ASEA, Sweden \\
\hline Wanapum & Washington & 1964 & 10 & 24 & 90 & 86 & 87,500 & $\begin{array}{l}\text { Dominion } \\
\text { Engineering } \\
\text { Works } \\
\end{array}$ & GE, USA \\
\hline$\overline{\text { Yacyretá }}$ & $\begin{array}{l}\text { Argentina and } \\
\text { Paraguay }\end{array}$ & $\begin{array}{c}\text { Under } \\
\text { Construction }\end{array}$ & 20 & 21 & 138 & 71 & 172,500 & ToBeAwarded & To Be Awarced \\
\hline
\end{tabular}


Francis

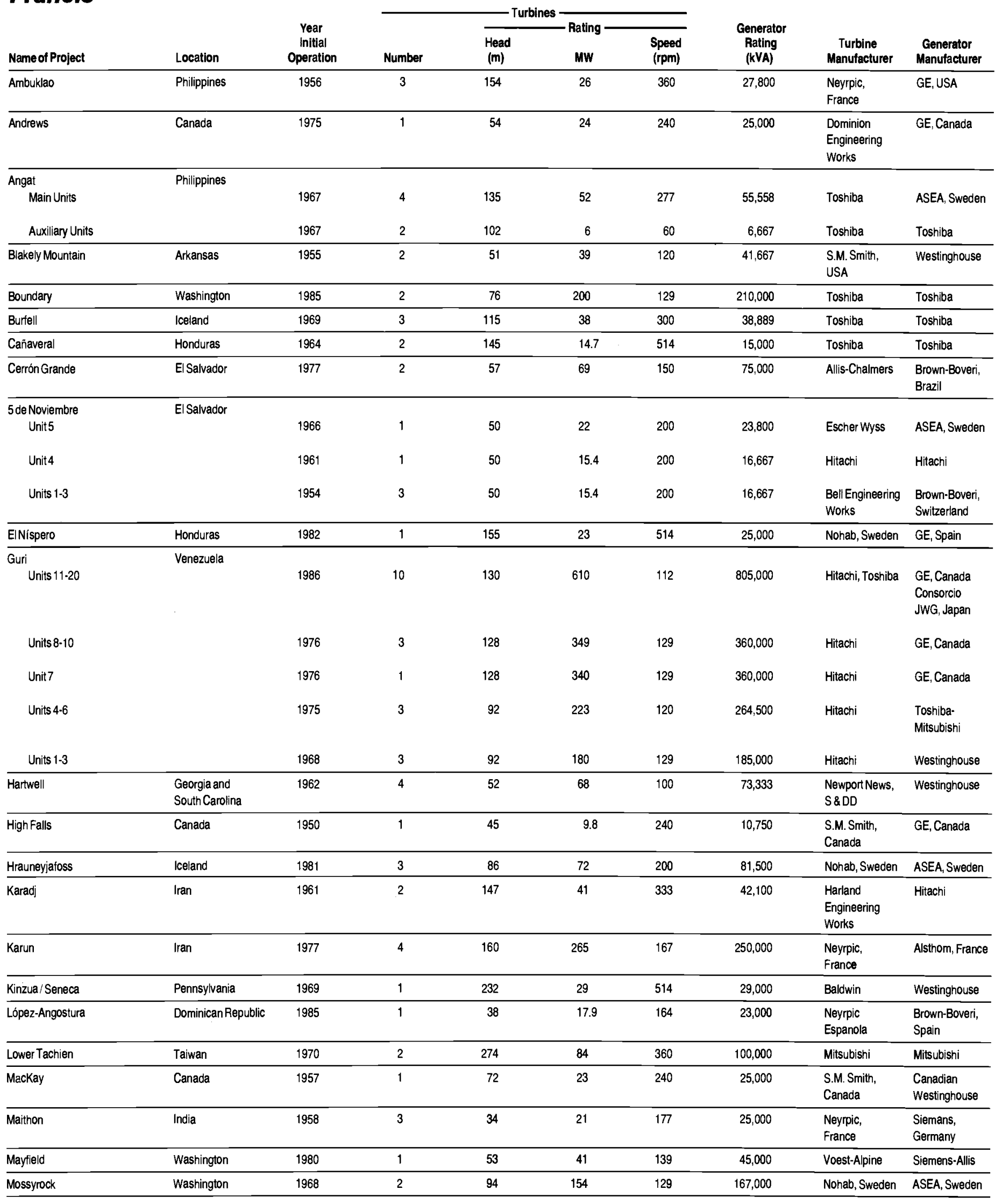

